INSTITUTO DE PESQUISAS ENERGÉTICAS E NUCLEARES

Autarquia associada à Universidade de São Paulo

\title{
ESTUDO DAS PROPRIEDADES MECÂNICAS E DOS MECANISMOS DE FRATURA DE FIBRAS SINTÉTICAS DO TIPO NÁILON E POLIÉSTER EM TECIDOS DE ENGENHARIA
}

SERGIO GOMES CARDOSO

Tese apresentada como parte dos requisitos para obtenção do Grau de Doutor em Ciências na Área de Tecnologia Nuclear - Materiais.

Orientador:

Prof. Dr. Arnaldo H. Paes de Andrade

São Paulo

2009 
Dedico à família, minha esposa Rosângela e minhas filhas Caroline e Karine. 


\section{AGRADECIMENTOS}

Ao professor Dr. Arnaldo Homobono Paes de Andrade, pela perfeita orientação, confiança e apoio contínuos.

Ao Instituto de Pesquisas Energéticas e Nucleares, pela oportunidade, incentivo e direcionamento nas disciplinas didáticas.

Ao Centro de Pesquisas de Paulínia da Rhodia Poliamida, pelos ensaios de análise por microscopia eletrônica de varredura nas fibras de náilon e poliéster.

Ao amigo Edélcio Tadeu de Oliveira Silvestre da Empresa Alvomax, pelos serviços de usinagem e ajustes no dispositivo de monitoramento do fio com ajuste de tensão manual, utilizado neste trabalho.

A Veyance Technologies do Brasil - Goodyear Produtos de Engenharia e, em especial, à Unidade Têxtil, aos amigos Pedro Roberto Padoan e Odilamar Aparecida Mauro, pela experiência têxtil e realização dos ensaios físicos nas fibras de náilon e poliéster.

A todos os companheiros, amigos e familiares que, direta ou indiretamente, estiveram presentes nos momentos de insegurança e tornaram esta jornada menos tortuosa. 


\section{SUMÁRIO}

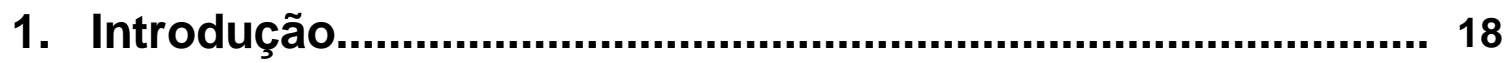

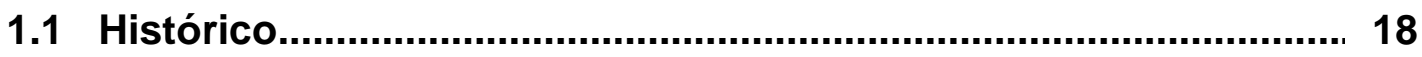

1.2 Objetivos.................................................................................... 21

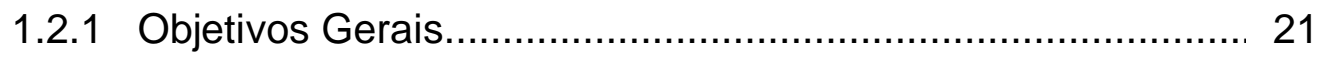

1.2.2 Objetivos Específicos....................................................... 21

1.2.3 Escopo de pesquisa....................................................... 22

1.2.4 Contribuição de pesquisa................................................. 23

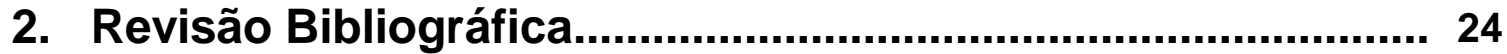

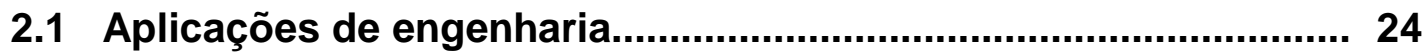

2.1.1 Materiais poliméricos.................................................. 27

2.1 .2 Fibras ....................................................................... 30

2.1.3 Classificação das fibras.................................................. 32

2.1.3.1 Fibras artificiais.................................................. 33

2.1.3.2 Fibras sintéticas................................................. 33

2.1.4 Processamento de fibras................................................... 33

2.1.5 Panorama mundial de fabricação de fibras........................... 36

2.1.6 Fibras de alto desempenho.............................................. 38

2.1.7 Propriedades básicas das fibras.......................................... 43

2.1.8 Resistência mecânica das fibras.......................................... 44

2.1.9 Outras propriedades das fibras........................................ 45

2.1.9.1 Módulo inicial...................................................... 45

2.1.9.2 Energia na ruptura............................................... 45

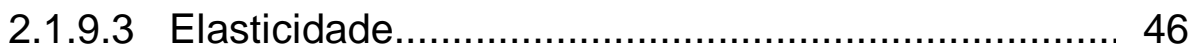

2.1.10 Técnicas de medição das forças multidirecionais nas

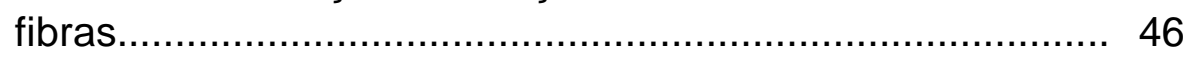

2.2 Fibras têxteis...................................................................... 47

2.2.1 Acabamento nas fibras têxteis........................................... 47

2.2.1.1 Estiramento nas fibras têxteis................................ 48

2.2.1.2 Processo de integração nas fibras têxteis............... 49

2.2.2 Fibras de náilon.............................................................. 52

2.2.2.1 Propriedades de umidade do náilon....................... 54

2.2.2.2 Propriedades de encolhimento do náilon.................. 55

2.2.2.3 Temperatura de transição vítrea $(\mathrm{Tg})$...................... 55

2.2.3 Fibras de poliéster........................................................ 56

2.2.3.1 Síntese do poliéster............................................ 58

2.2.3.2 Efeito das modificações químicas e físicas nas fibras de poliéster................................................. 59

2.2.3.3 Efeito da radiação nos poliésteres........................... 60 
2.2.3.4 Efeito da temperatura nos poliésteres.................... 60

2.2.3.5 Propriedades mecânicas dos poliésteres................. 61

2.2.3.6 Outras propriedades dos poliésteres....................... 63

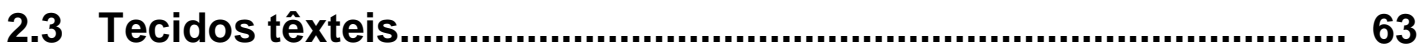

2.3.1 Construção de tecidos de engenharia.................................. 64

2.3.2 Acabamento têxtil em tecidos de engenharia........................ 65

2.3.3 Processos de manufatura de produtos de engenharia........... 66

2.3.3.1 Tecelagem do tecido cru....................................... 66

2.3.3.2 Dipagem do tecido cru.......................................... 67

2.3.3.3 Calandragem do tecido dipado.............................. 67

2.3.3.4 Construção do tecido dipado................................... 68

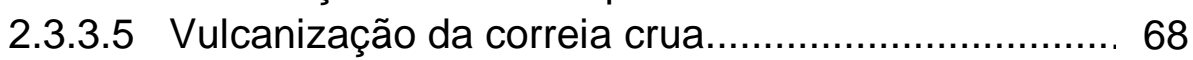

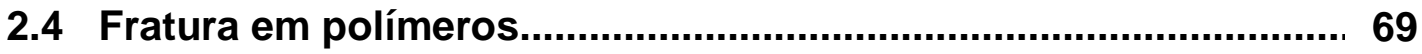

2.4.1 Falhas mecânicas......................................................... 69

2.4.2 Fratura em materiais polímericos......................................... 70

2.4.3 Mecanoquímica macromolecular do polímero........................ 71

2.4.4 Fratura de fibras têxteis.................................................. 74

2.4.5 Fratura a alta velocidade de fibras têxteis........................... 74

2.5 Caracterização das fibras têxteis................................................. 74

2.5.1 Microscopia ótica em fibras têxteis..................................... 75

2.5.2 Microscopia eletrônica de varredura em fibras têxteis............ 76

2.5.3 Microscopia eletrônica de transmissão em fibras têxteis........ 77

2.6 Análise por elementos finitos.................................................. 78

3. Materiais e Métodos.............................................................. 79

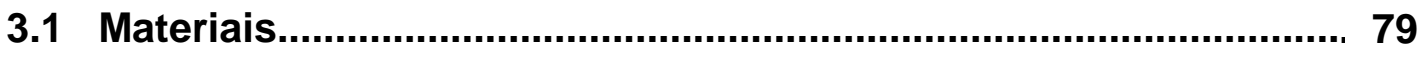

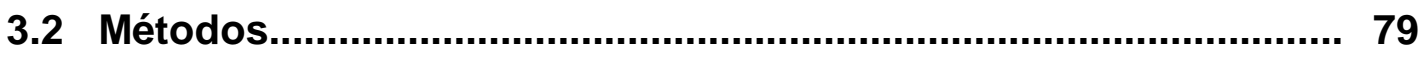

3.2.1 Ensaios analíticos e destrutivos nas fibras de náilon e poliéster................................................................ 79

3.2.2 Ensaio de tração monitorado do fibra com ajuste de tensão

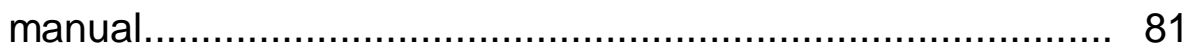

3.2.3 Ensaios de tração monitorado no tecido ............................. 82

3.2.4 Microscopia eletrônica de varredura.................................... 83

3.2.5 Ensaios de adesão interfacial........................................... 85

3.2.6 Desenvolvimento teórico.................................................... 86

4. Resultados e Discussão......................................................... 88

4.1 Fibras e Tecidos...................................................................... 90

4.1.1 Cálculo da força de ruptura "teórica versus experimental"..... 90

4.1.2 Ensaios de tração nas fibras de náilon da amostra da correia "A"....... 
4.1.3 Ensaios de tração nas fibras de náilon da amostra da correia "B"

4.1.4 Ensaios de tração nas fibras de poliéster da amostra da correia "C".

4.1.5 Ensaios de tração nas fibras de poliéster da amostra correia "D"

4.2 Ensaio de tração monitorado com ajuste de tensão manual........ 103

4.3 Ensaio de tração monitorado do tecido dipado 105

4.4 Ensaios por Microscopia eletrônica de varredura......................... 109

5. Conclusões........................................................................... 139

6. Sugestões para Trabalhos Fututos.................................... 141

Apêndice A - Estatística de Weilbull..................................... 142

Referências Bibliográficas................................................... 147 


\section{LISTA DE FIGURAS}

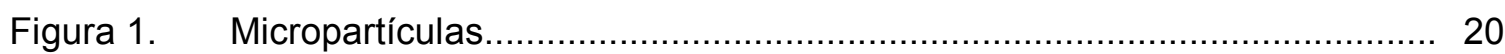

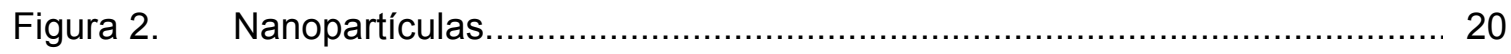

Figura 3. Filamento sem revestimento............................................................. 20

Figura 4. Filamento com 2\% de revestimento..................................................... 20

Figura 5. Sistema transportador................................................................... 25

Figura 6. Sistemas transportadores para britagem do minério de urânio.................... 25

Figura 7. Correia transportadora de carvão para geração de energia........................ 26

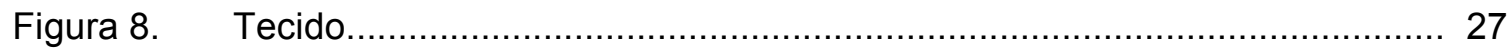

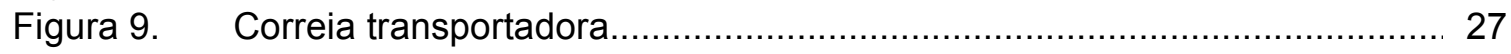

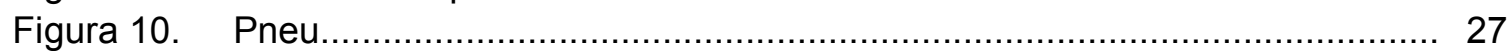

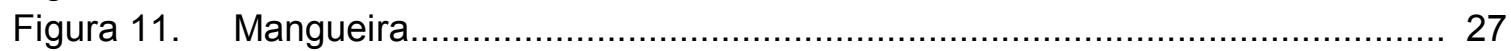

Figura 12. Mola pneumática.......................................................................... 27

Figura 13. Monômeros de etileno …................................................................... 28

Figura 14. Polímeros $\mathrm{C}_{2} \mathrm{H}_{4}$ (meros) ................................................................. 28

Figura 15. Classificação das cadeias para o polipropileno....................................... 30

Figura 16. Tecidos com fibras........................................................................... 33

Figura 17. Classificação das fibras têxteis............................................................. 35

Figura 18. Configuração básica da cadeia têxtil...................................................... 35

Figura 19. Fluxograma da cadeia de produção das principais fibras sintéticas........... 36

Figura 20. Produção mundial de fibras têxteis........................................................ 37

Figura 21. Consumo mundial de fibras têxteis........................................................ 38

Figura 22. Estrutura molecular do kevlar....................................................... 40

Figura 23. Concepção de fibras híbridas.............................................................. 41

Figura 24. Construção básica da corda............................................................. 43

Figura 25. Esquema de medição das forças multidirecionais..................................... 46

Figura 26. Sentido de torção da fibra têxtil............................................................ 47

Figura 27. Estrutura molecular amorfa e cristalina em polímeros................................ 48

Figura 28. Processo de fiação do náilon.............................................................. 50

Figura 29. Processo de fiação do poliéster............................................................ 51

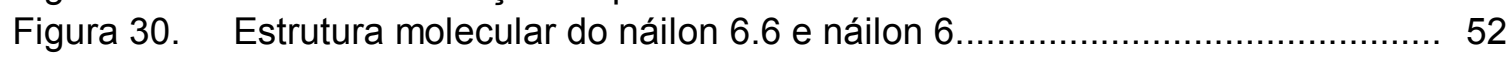

Figura 31. Estrutura típica das fibras de náilon...................................................... 53

Figura 32. Estrutura molecular do poliéster........................................................ 57

Figura 33. Reação de condensação do poliéster................................................... 58

Figura 34. Estrutura típica das fibras de poliéster.................................................. 59

Figura 35. Construção básica estrutural do tecido têxtil............................................ 64

Figura 36. Construção plana com uma fibra ......................................................... 65

Figura 37. Construção plana com duas fibras....................................................... 65

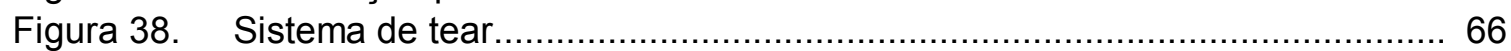

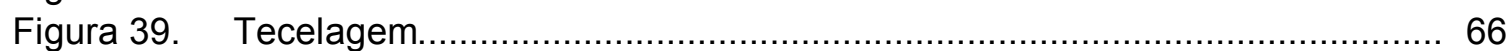

Figura 40. Sistema de dipagem para tecidos.......................................................... 67

Figura 41. Processo de vulcanização de correia transportadora..................................6 69

Figura 42. Lacunas no carregamento...………………………………………... 70 


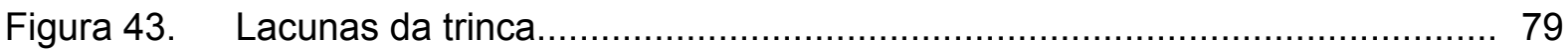

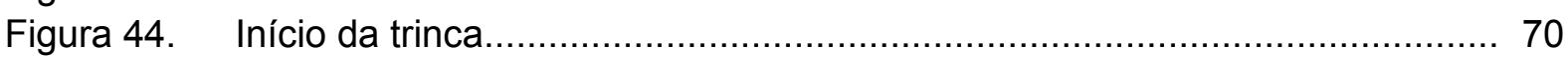

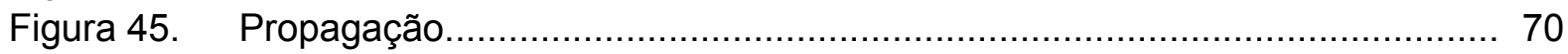

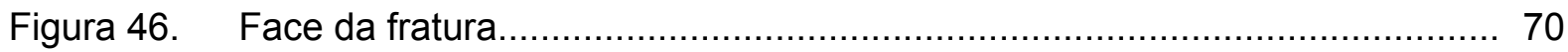

Figura 47. Curvas típicas de tensão-deformação para materiais poliméricos............... 71

Figura 48. Mecanismo de geração da microtrinca nascente ....................................... 73

Figura 49. Mecanismo de geração da trinca principal.............................................. 73

Figura 50. Microscópio eletrônico de varredura convencional.................................... 76

Figura 51. Modelamento de uma correia transportadora............................................. 78

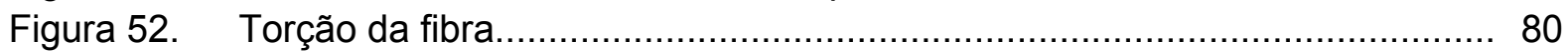

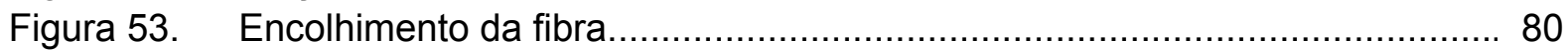

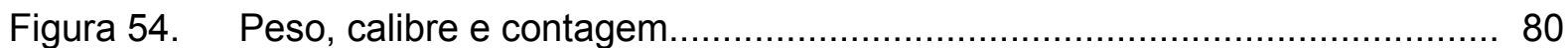

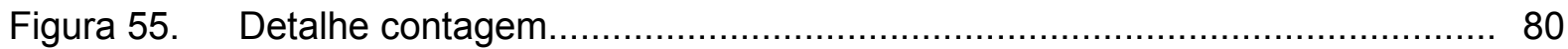

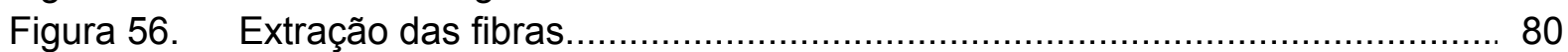

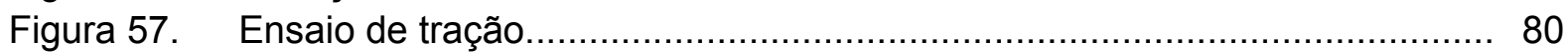

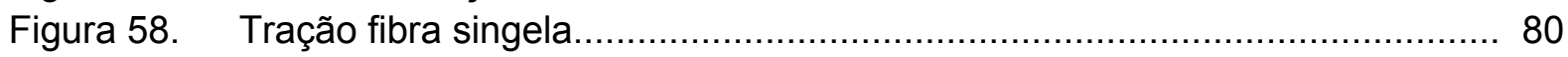

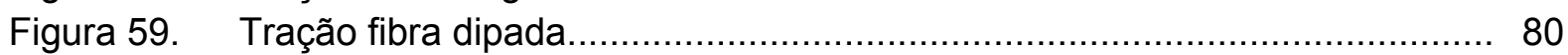

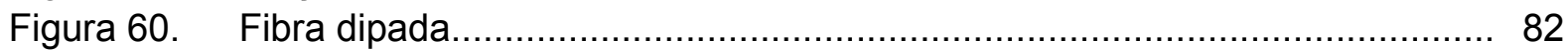

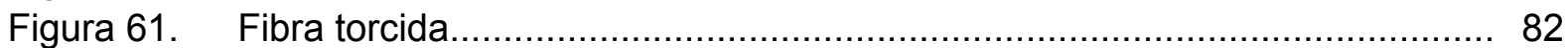

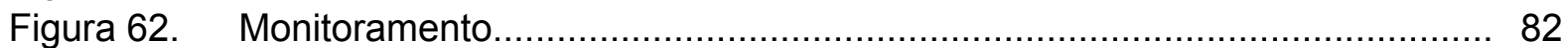

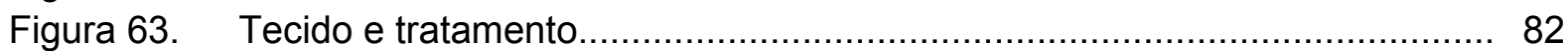

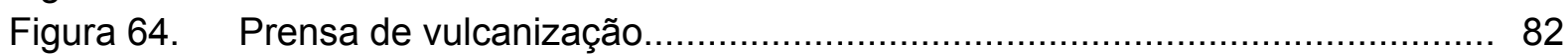

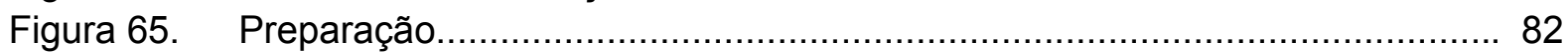

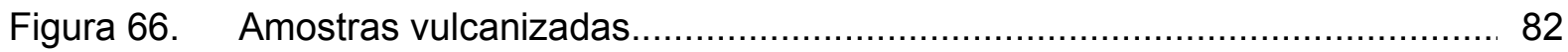

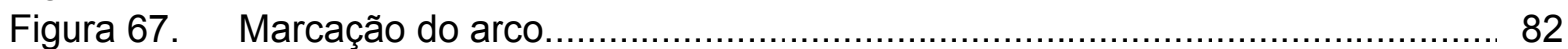

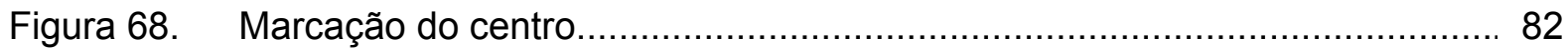

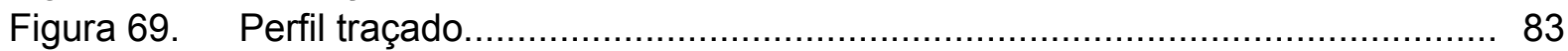

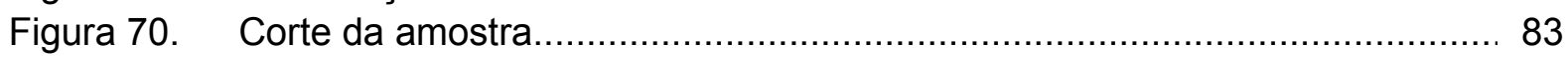

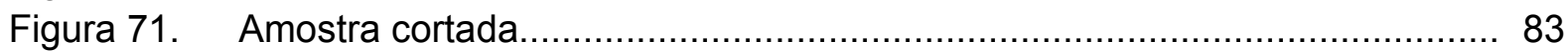

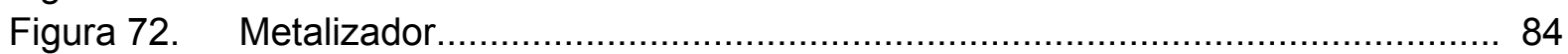

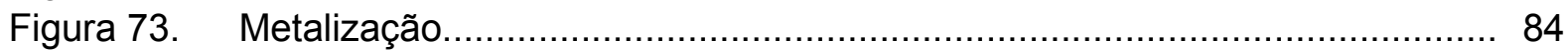

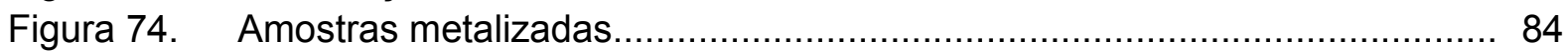

Figura 75. Microscópio eletrônico de varredura...................................................... 84

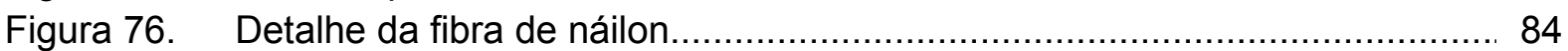

Figura 77. Ensaio de adesão entre a cobertura e o $1^{\circ}$ tecido......................................... 85

Figura 78. Resultados de tensão de ruptura da fibra de náilon (Amostra "A").............. 95

Figura 79. Resultados de alongamento da fibra de náilon (Amostra "A")...................... 95

Figura 80. Resultados de tensão de ruptura da fibra de náilon (Amostra "B").............. 96

Figura 81. Resultados de alongamento da fibra de náilon (Amostra "B")..................... 97

Figura 82. Resultados de tensão de ruptura da fibra de poliéster (Amostra "C").......... 98

Figura 83. Resultados de alongamento da fibra de poliéster (Amostra "C").................. 98

Figura 84. Resultados de tensão de ruptura da fibra de poliéster (Amostra "D").......... 99

Figura 85. Resultados de alongamento da fibra de poliéster (Amostra "D").................. 100

Figura 86. Perda residual por temperatura para o poliéster....................................... 101

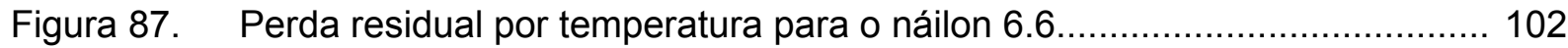




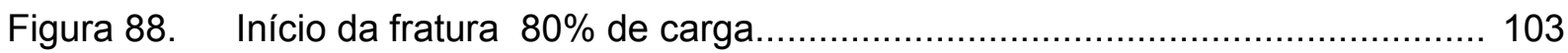

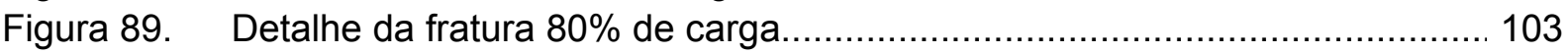

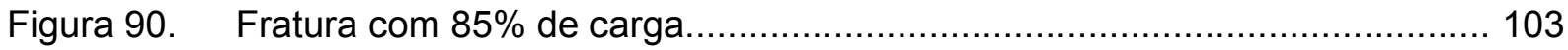

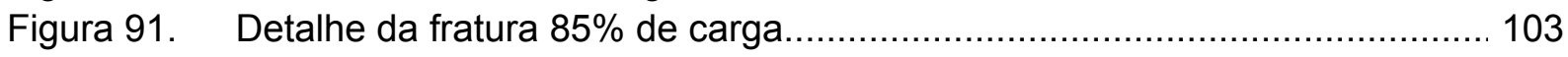

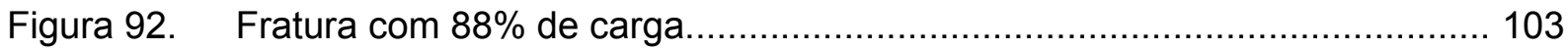

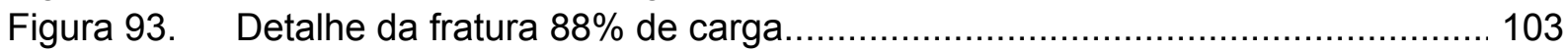

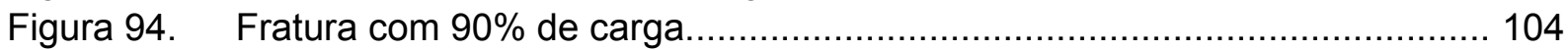

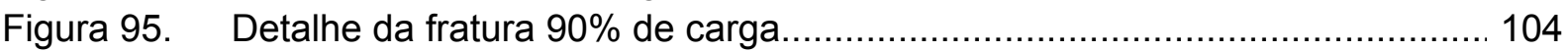

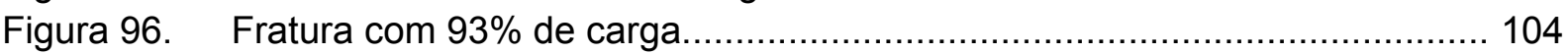

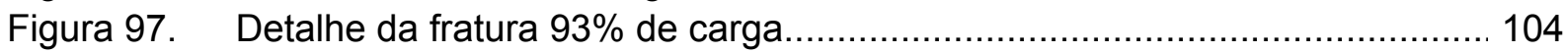

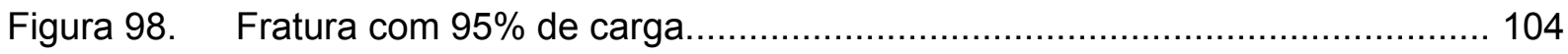

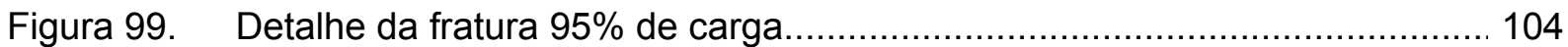

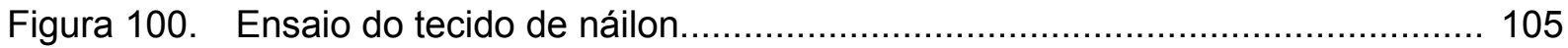

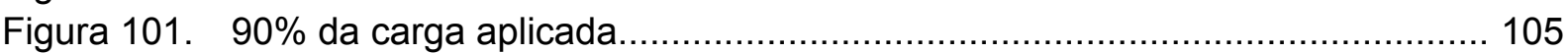

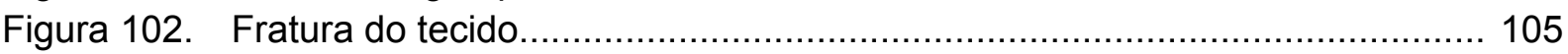

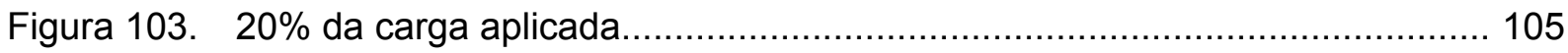

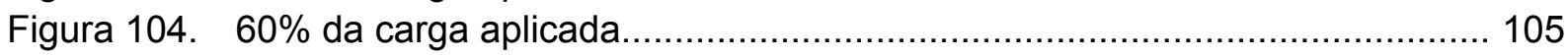

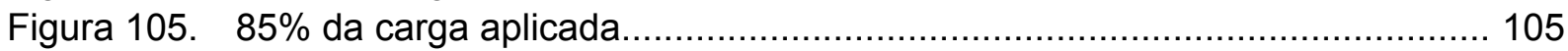

Figura 106. Ensaio de tecido de poliéster................................................................. 106

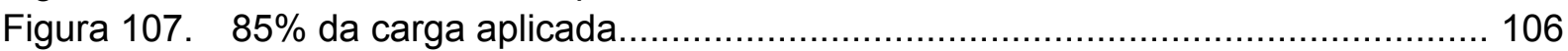

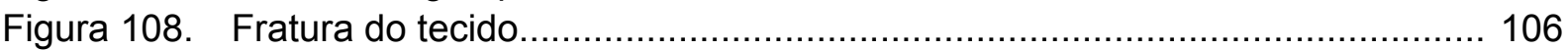

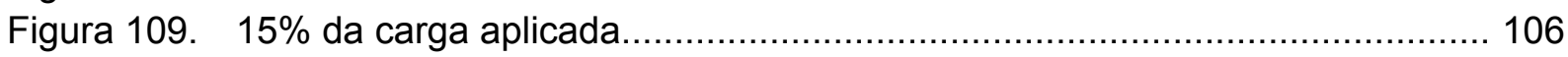

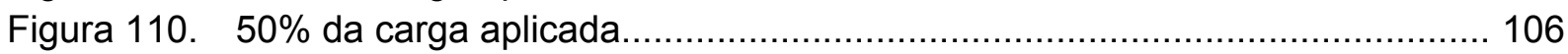

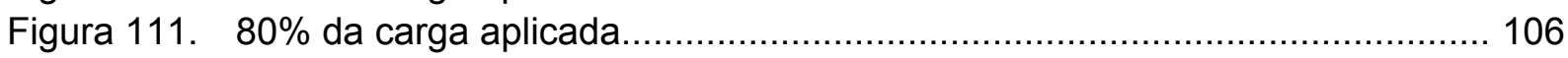

Figura 112. Gráfico tensão $x$ deformação para o tecido dipado de náilon....................... 107

Figura 113. Gráfico tensão $x$ deformação para o tecido dipado de poliéster..................... 108

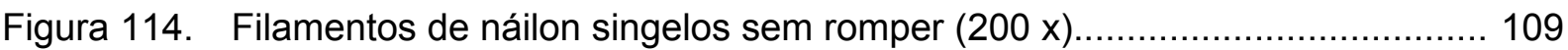

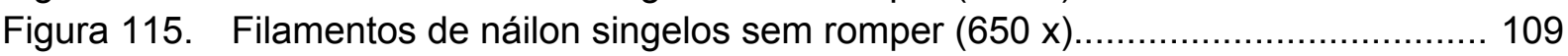

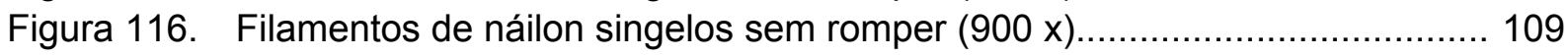

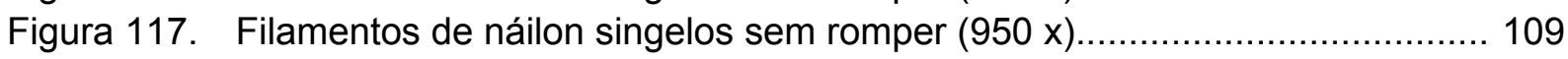

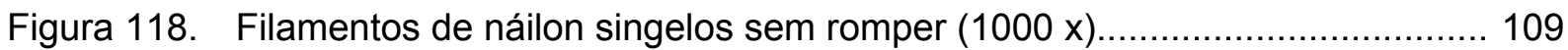

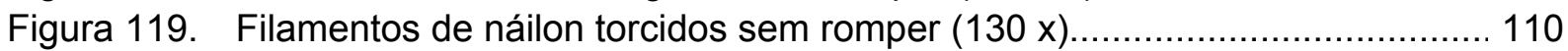

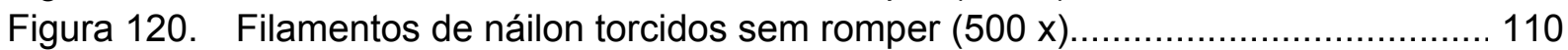

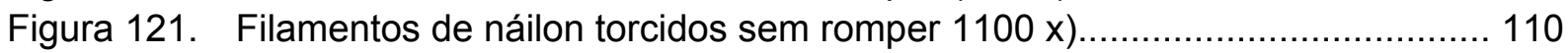

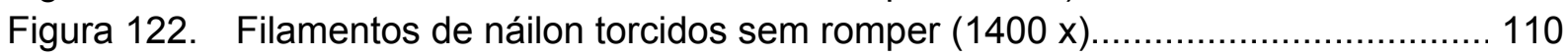

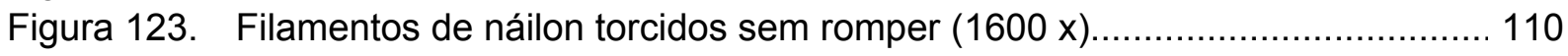

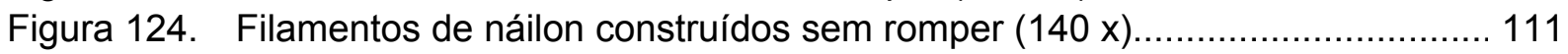

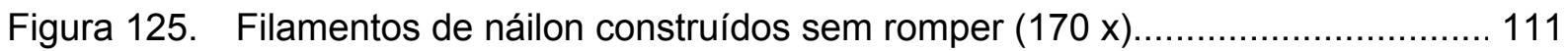

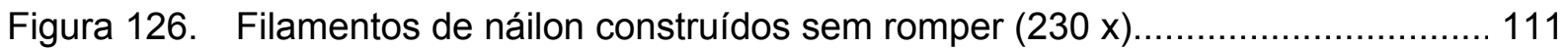

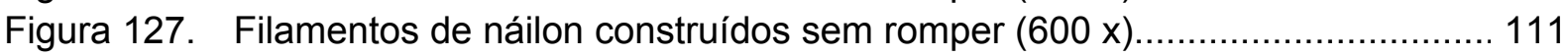

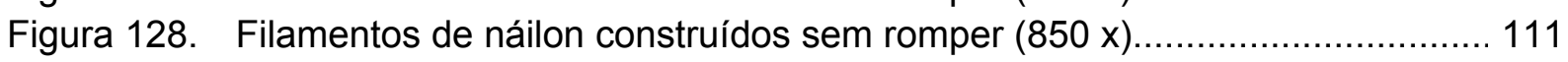

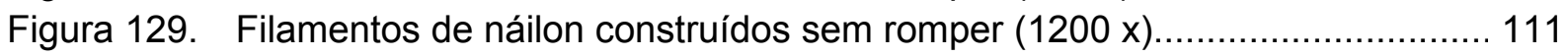

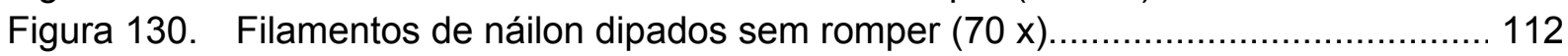

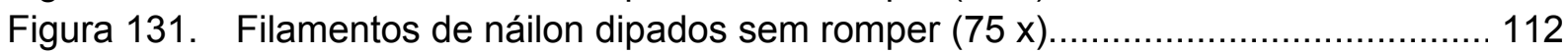

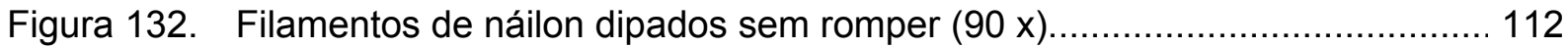




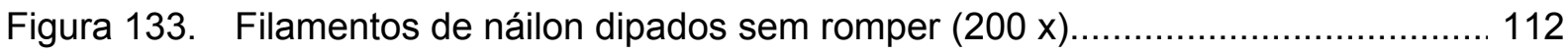

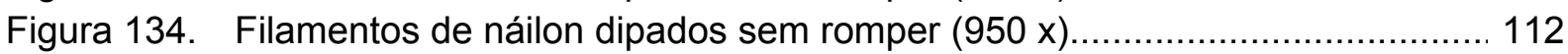

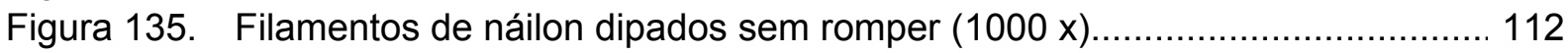

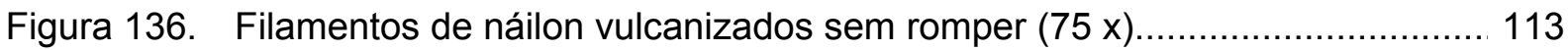

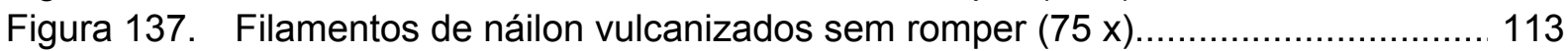

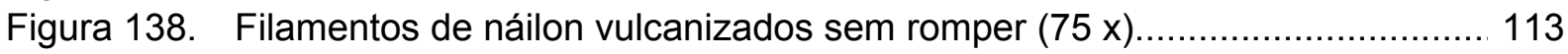

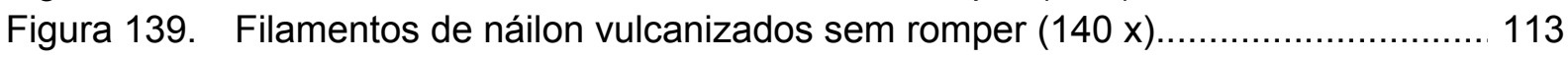

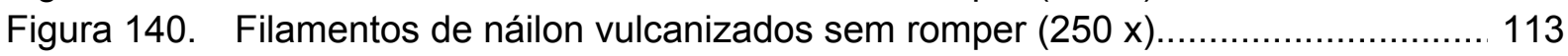

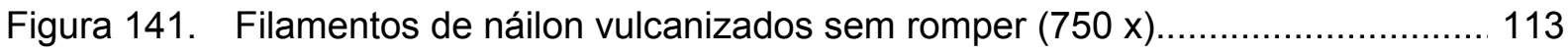

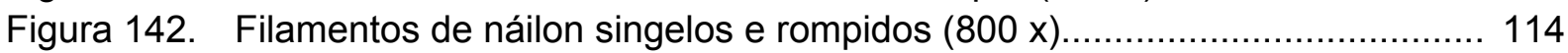

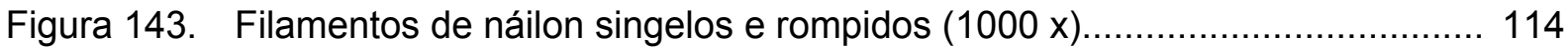

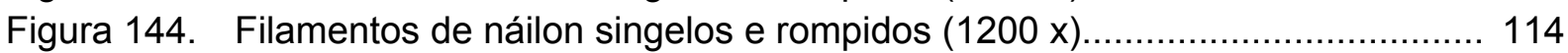

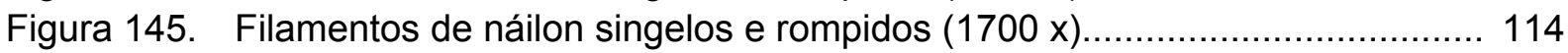

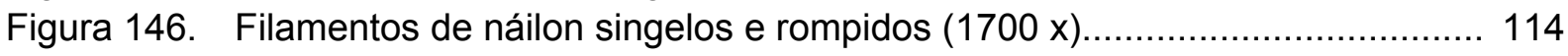

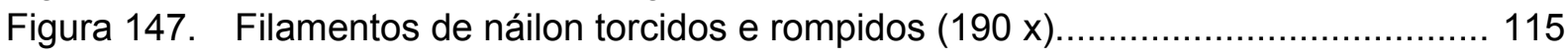

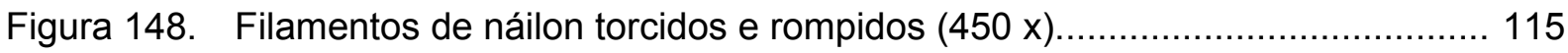

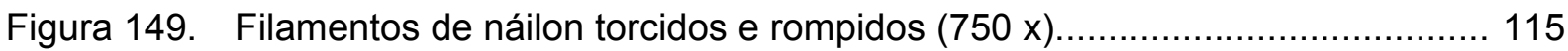

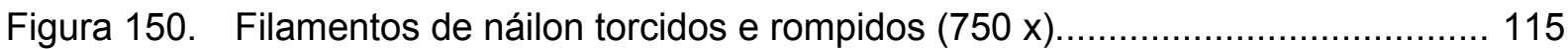

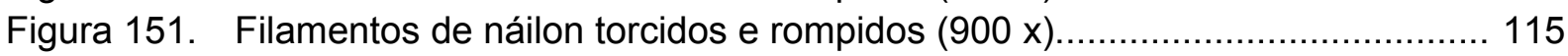

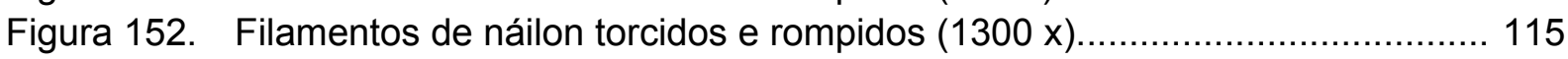

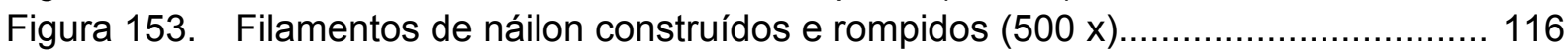

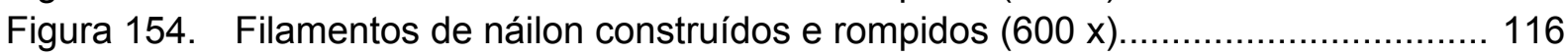

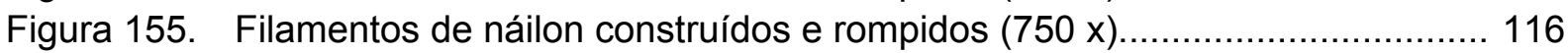

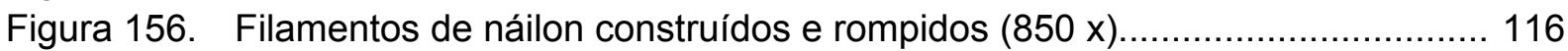

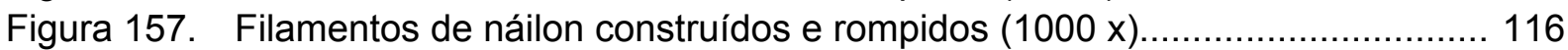

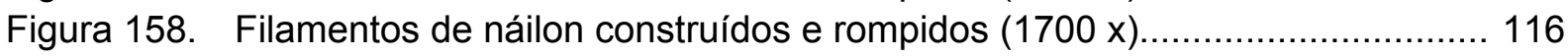

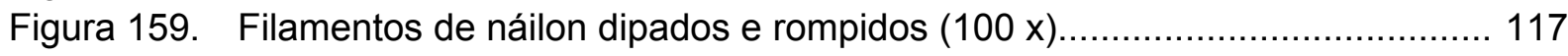

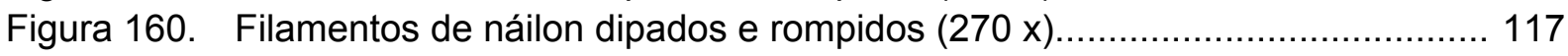

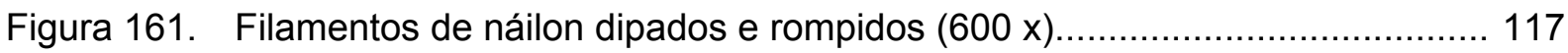

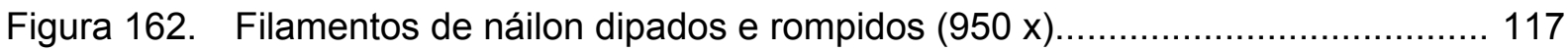

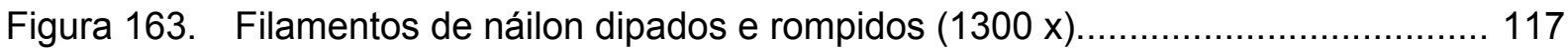

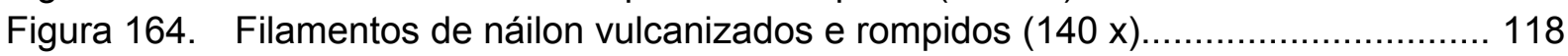

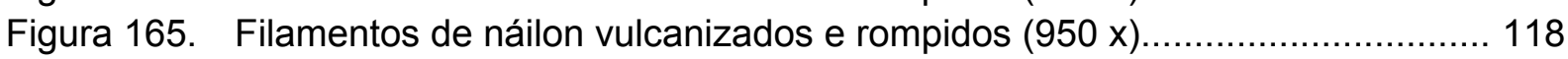

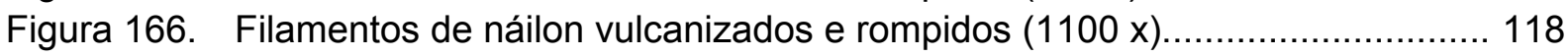

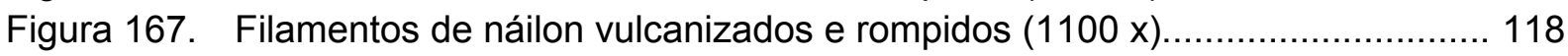

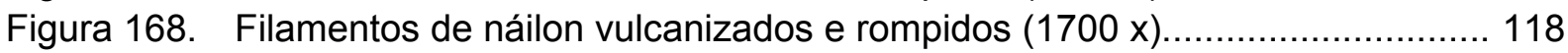

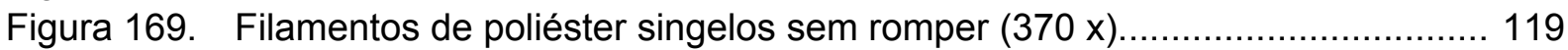

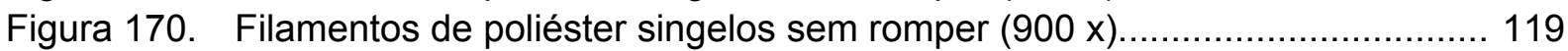

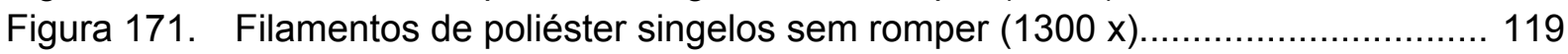

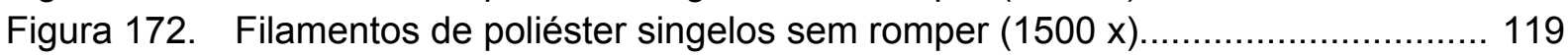

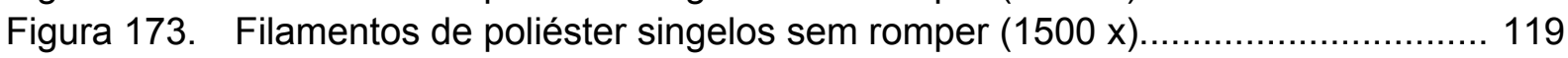

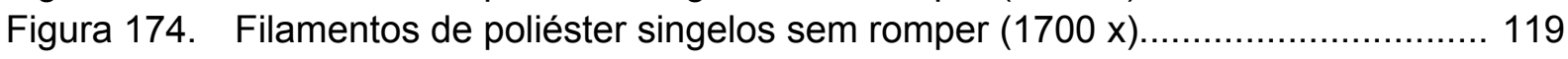

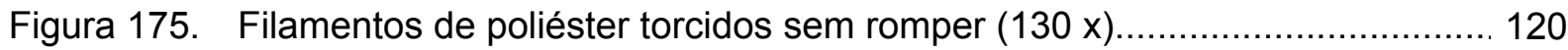




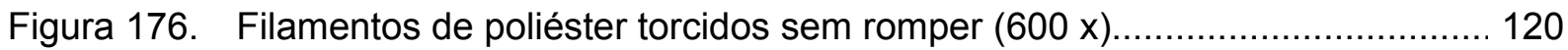

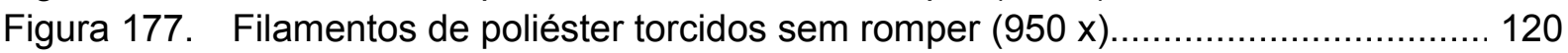

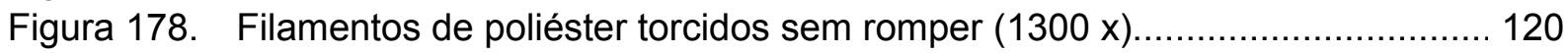

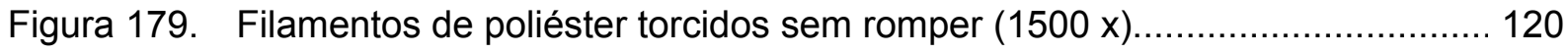

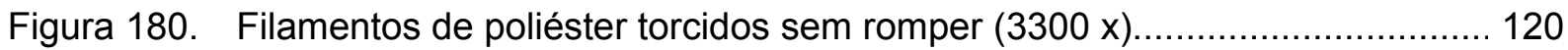

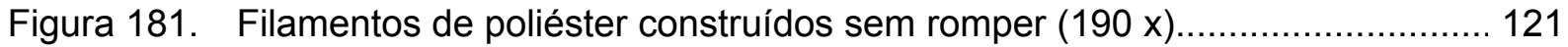

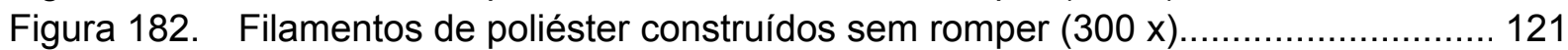

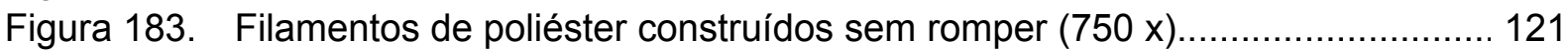

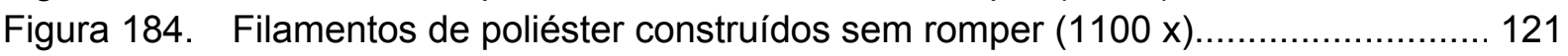

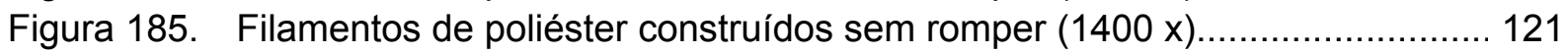

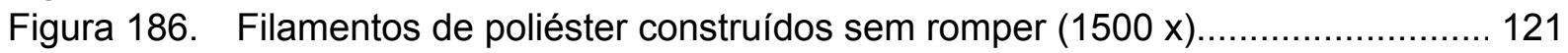

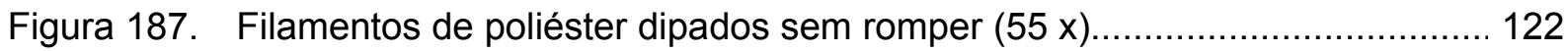

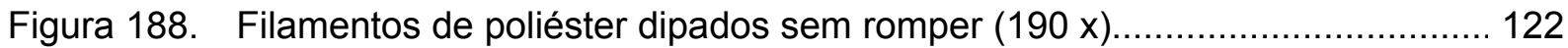

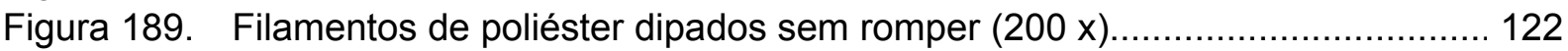

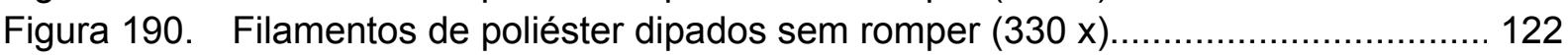

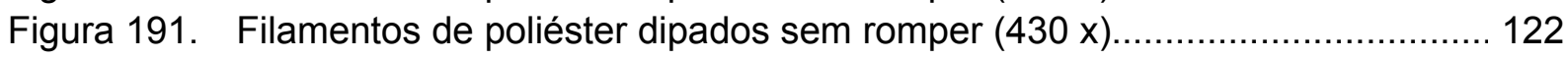

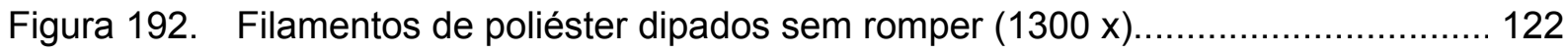

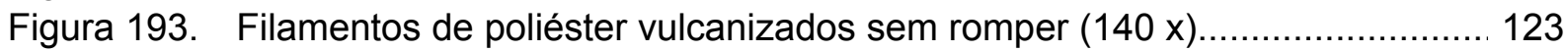

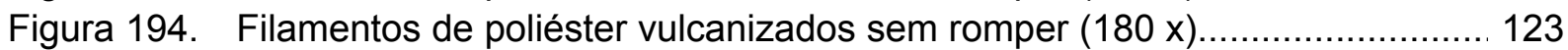

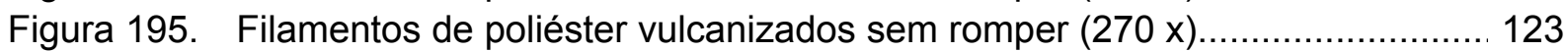

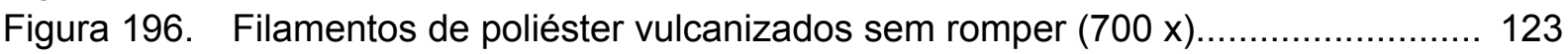

Figura 197. Filamentos de poliéster vulcanizados sem romper $(2200 \mathrm{x}) \ldots \ldots \ldots \ldots \ldots \ldots \ldots \ldots \ldots \ldots \ldots \ldots \ldots \ldots . . . . .123$

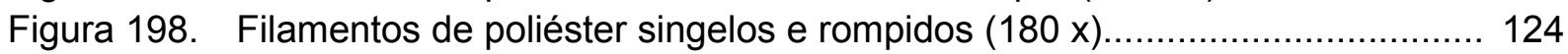

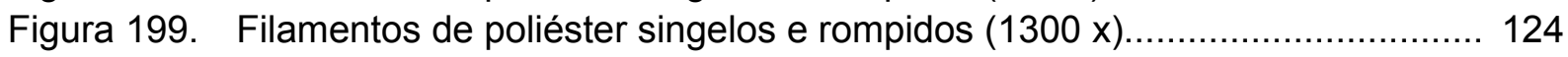

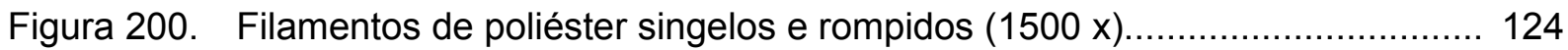

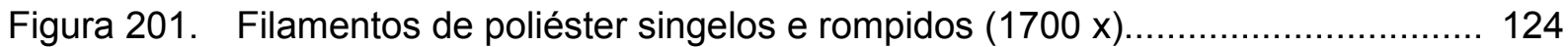

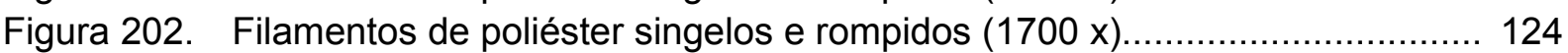

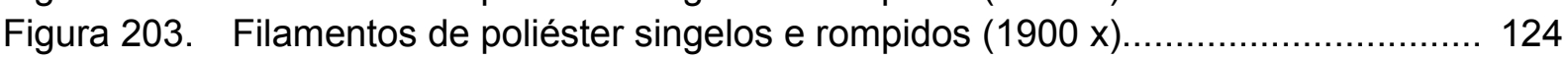

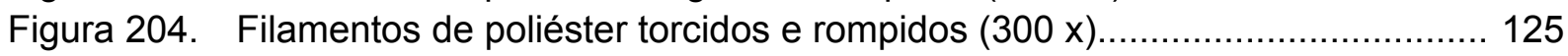

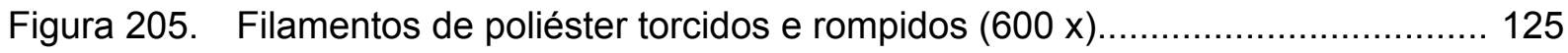

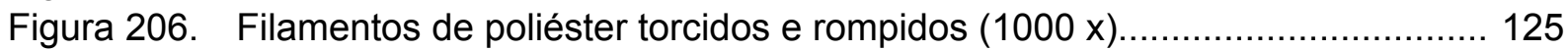

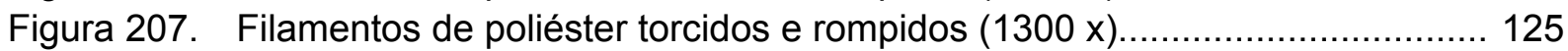

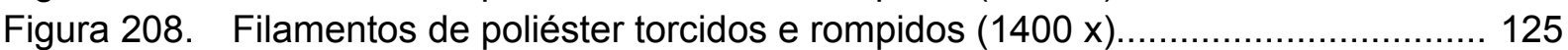

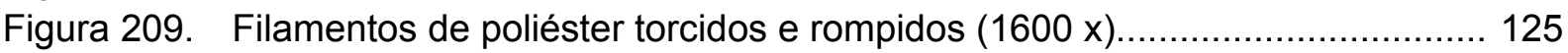

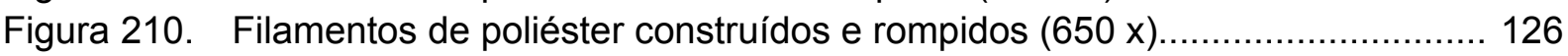

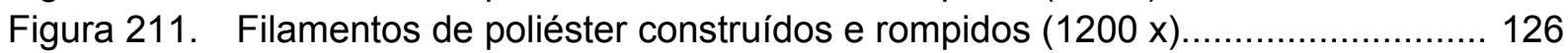

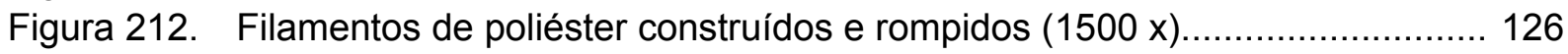

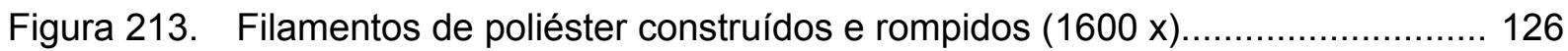

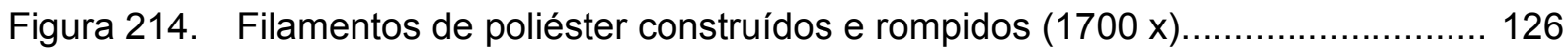

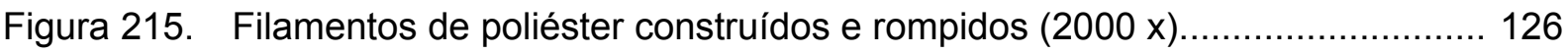

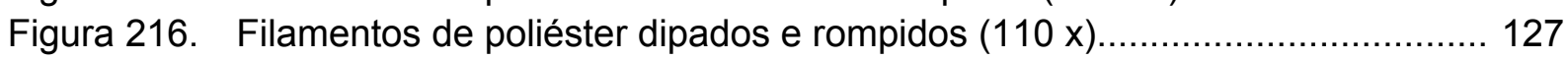

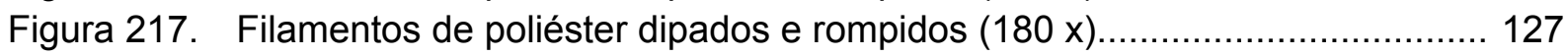

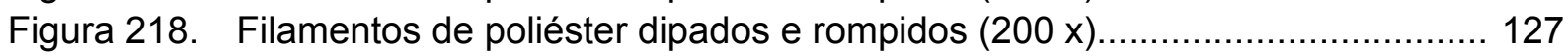

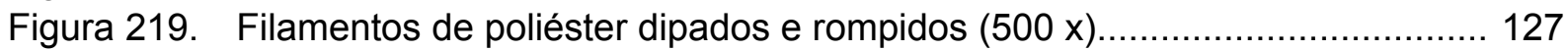

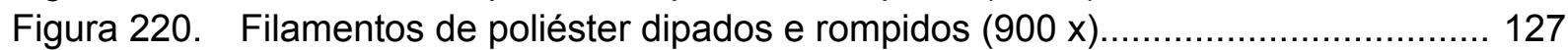




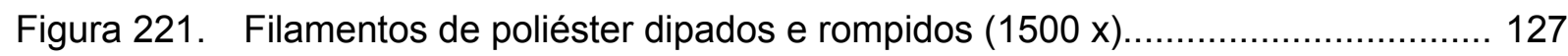

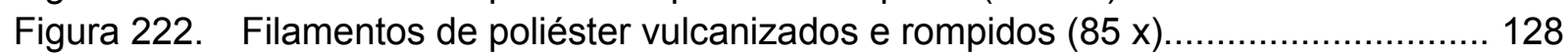

Figura 223. Filamentos de poliéster vulcanizados e rompidos $(95 \mathrm{x})$............................. 128

Figura 224. Filamentos de poliéster vulcanizados e rompidos $(270 \mathrm{x})$............................ 128

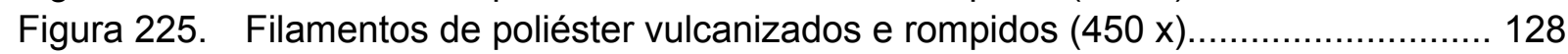

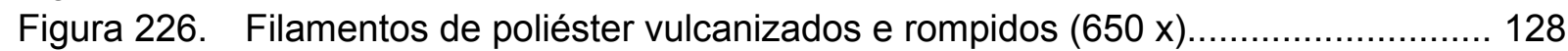

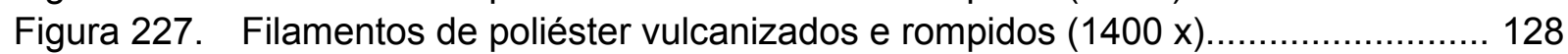

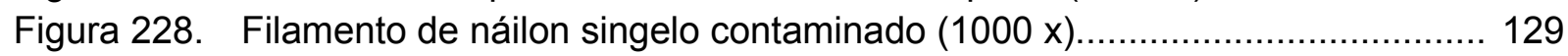

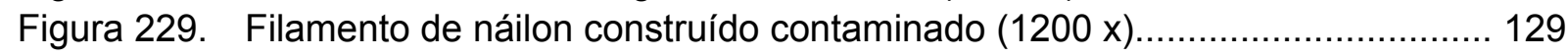

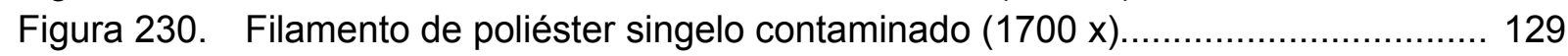

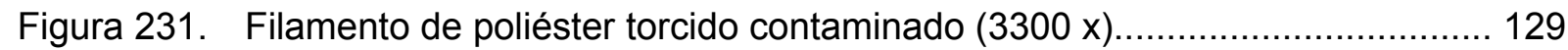

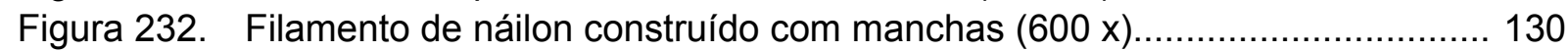

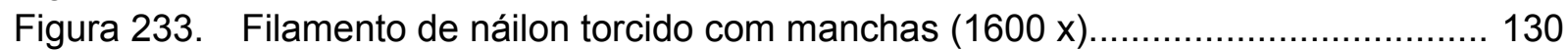

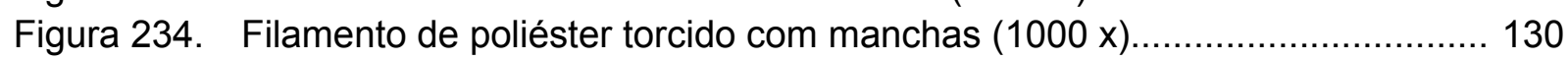

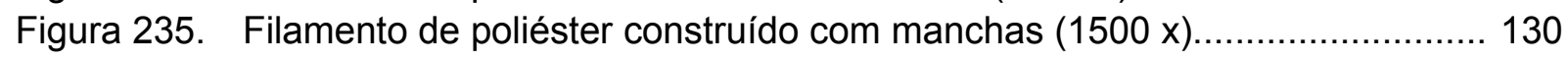

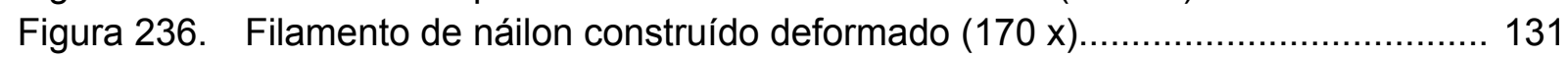

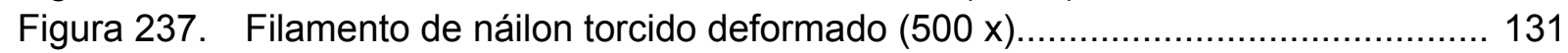

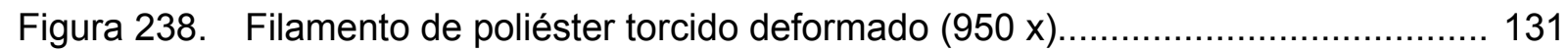

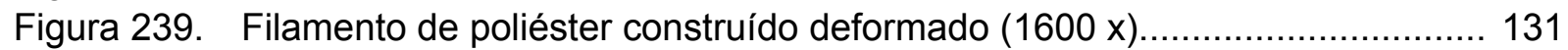

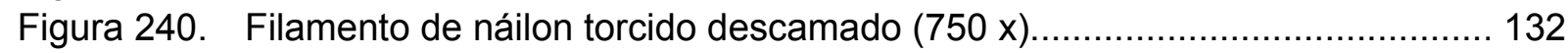

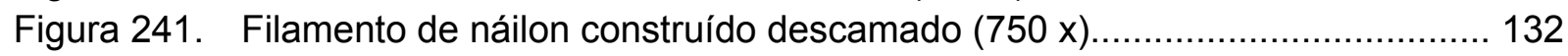

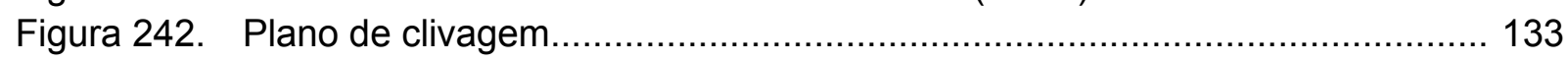

Figura 243. Deslocamento lateral ................................................................... 133

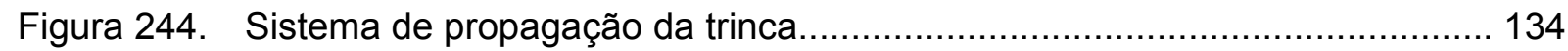

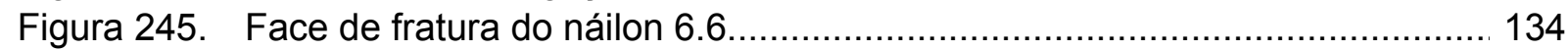

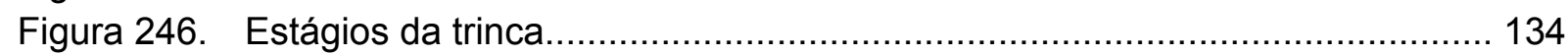

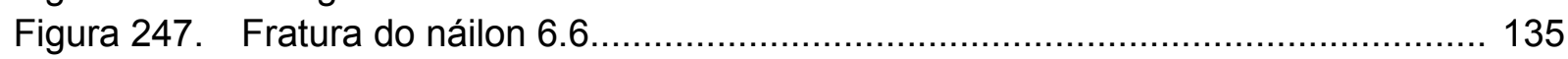

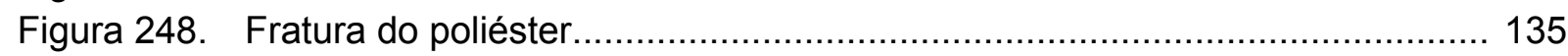

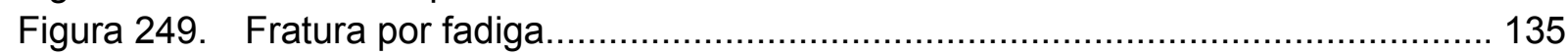

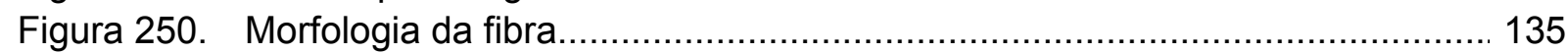

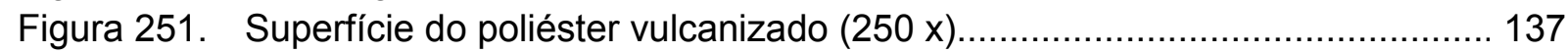

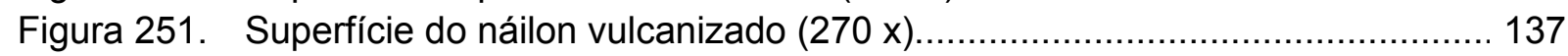

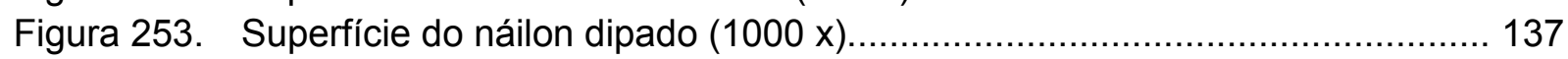

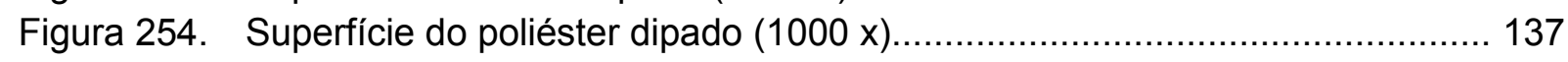

Figura 255. Filamento de poliéster vulcanizado (náilon $1400 \mathrm{x}$ ).................................. 137

Figura 256. Filamento de náilon vulcanizado (náilon $1700 \mathrm{x}$ )....................................... 137 


\section{LISTA DE TABELAS}

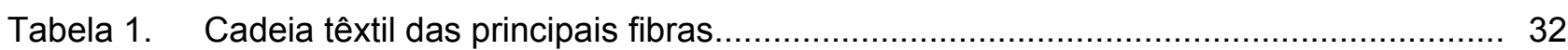

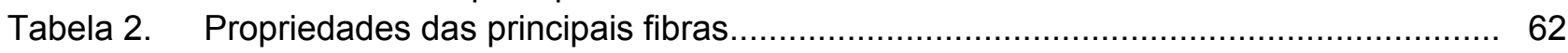

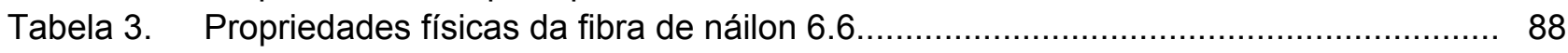

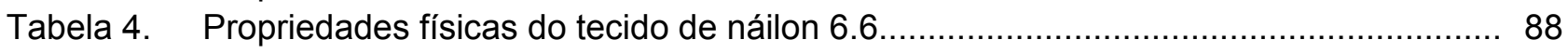

Tabela 5. Propriedades físicas da fibra de poliéster............................................................ 89

Tabela 6. Propriedades físicas do tecido de poliéster....................................................... 89

Tabela 7. Força de ruptura teórica versus experimental para a amostra de náilon "A".............. 91

Tabela 8. Força de ruptura teórica versus experimental para a amostra de náilon "B".............. 91

Tabela 9. Força de ruptura teórica versus experimental para a amostra de poliéster "C"........... 92

Tabela 10. Força de ruptura teórica versus experimental para a amostra de poliéster "D"........... 92

Tabela 11. Resultados de ruptura, alongamento e desvios para a amostra de náilon "A"............ 93

Tabela 12. Resultados de ruptura, alongamento e desvios para a amostra de náilon "B"............ 93

Tabela 13. Resultados de ruptura, alongamento e desvios para a amostra de poliéster "C"........ 94

Tabela 14. Resultados de ruptura, alongamento e desvios para a amostra de poliéster "D"........ 94

Tabela 15. Resultados de adesão de tecidos do tipo náilon e poliéster..................................... 138 


\section{LISTA DE ABREVIATURAS E SIGLAS}

$\mathrm{PbO}$ - Óxido de chumbo

$2 \mathrm{PbCO}_{3} \cdot \mathrm{Pb}(\mathrm{OH})_{2}-$ Carbonato básico de chumbo

ABS - Acrilonitrila Butadieno Estireno

FRP - Fiber Reinforced Plastic

DMT - Dimetil Tereftalato

TPA - Ácido Tereftalato

MDI - Metil Difenil Isocianato

ITMF - International Textile Manufacturers Federation

NASA - National Aeronautics and Space Administration

SI - Sistema Internacional

ISO - International Organization for Standardization

DP - Degree of Polymerization

PEUAPM - Polietileno de Ultra-alto Peso Molecular

UHMWPE - Ultra High Molecular Weight Poly-Ethylene

FTC - Federal Trade Commission

PET - Poli (etileno tereftalato)

SAS - Small Angle Scattering

MO - Microscopia Ótica

MEV - Microscopia Eletrônica de Varredura

MET - Microscopia Eletrônica de Transmissão

FEA - Finite Elements Analyse

EU - European Union

IUPAC - International Union Pure and Applied Chemistry

PBT - Polibutileno Tereftalato

PRFV - Plástico Reforçado com Fibra de Vidro

PTT - Politrimetileno Tereftalato

$\mathrm{TiO}_{2}$ - Óxido de titânio

NIST - National Institute of Standards and Technology

IR - Infravermelho 


\section{SímBOLOS}

$\mathrm{T}_{\mathrm{g}}$ : Temperatura de Transição Vítrea

tex: Unidade do sistema internacional utilizada para medir o grau de pureza das fibras em gramas por 1000 metros de comprimento

dtex: Mesma unidade em gramas por 10.000 metros de comprimento

g: Gramas

GPa: Giga Pascal

$\mu \mathrm{m}$ : Micrômetro

nm: Nanômetro

D: Densidade linear

$\mathrm{cN}$ : Centinewton

$\mathrm{N}$ : Newton

mm: Milímetros

kg: Quilograma

kN: Quilo Newton

m: Metro

P1: Peso do feixe de fibra

P2: Peso do filamento

$\mathrm{n}$ : número de filamentos do feixe

Ac: Área circular

$\pi$ : constante pi equivalente a 3,1416

d: Diâmetro

V: Volume

I : Comprimento

$\rho:$ Peso específico ou densidade

F: Força

$\sigma:$ Tensão

$\mathrm{D}_{\mathrm{m}}$ : Diâmetro médio

$A_{m}$ : Área média

$\mathrm{T}$ : Tenacidade

A: Área

$F_{\text {teo }}$ : Força teórica

$F_{\text {exp }}$ : Força experimental 


\section{RESUMO}

Fibras são definidas como o conjunto formado de filamentos orientados na direção da cadeia molecular e são parte fundamental na vida diária do ser humano, encontradas de várias formas, tais como filamentos, fios, feixes, cordas, tecidos, compósitos, revestimentos, entre outras. Elas abrangem diversas áreas, tais como civil, mecânica, elétrica, eletrônica, militar, naval, náutica, aeronáutica, saúde, medicina, ambiental, comunicação, segurança, espacial, entre outras. A fibras são divididas em duas classes distintas, naturais e químicas, que compõem as subclasses sintéticas e artificiais. Podem ser produzidas de vários materiais, tais como lã, algodão, raion, linho, seda, rocha, náilon, poliéster, polietileno, polipropileno, aramida, vidro, carbono, aço, cerâmica, entre outros. Em nível global, as fibras químicas correspondem a $59,9 \%$ do mercado, sendo as fibras sintéticas tipo poliéster as mais utilizadas, com $63 \%$. Necessidades vitais têm levado ao desenvolvimento de fibras multifuncionais e o foco mudou nos últimos dez anos com a utilização da nanotecnologia para fibras de responsabilidade ambiental e fibras inteligentes. $O$ estudo das propriedades mecânicas e dos mecanismos de fratura das fibras é de grande importância para caracterização e entendimento das causas de falhas. Para este propósito foram selecionados tecidos fabricados com fibras sintéticas de alto desempenho do tipo náilon e poliéster, utilizadas em produtos de engenharia tais como pneus, correias, mangueiras e molas pneumáticas, as quais foram analisadas em cada etapa de processamento. Amostras das fibras foram retiradas de cada etapa de processamento para análise por ensaios destrutivos de tração e microscopia eletrônica de varredura. Os resultados de análise das propriedades mecânicas mostraram perda de resistência por temperatura e tensões multiaxiais durante as etapas de processamento da fibra. Por meio de ensaios de microscopia foi possível determinar contaminações, manchas superficiais, deformações plásticas, delaminações, variações nas faces de fratura dos filamentos e analisar, na interface fibra-borracha, o nível de adesão. Estas irregularidades e variações são causadas durante as etapas inerentes ao processo de fabricação. 


\begin{abstract}
Fibers are groups formed by molecular-chain-oriented filaments. Fibers play a fundamental role in human being's daily life and they can be found in several forms and geometries, such as filaments, yarns, beams, rope, fabric, composite, coatings, others. They are used in various segments such as civil, mechanical, electrical, electronics, military, naval, nautical, aviation, health, medicine, environment, communications, safety, space, others. Fibers are divided into two distinct classes: natural and chemical ones, which cover synthetic and man-made sub-classes. They can be produced from several materials, such as wool, cotton, rayon, flax, silk, rock, nylon, polyester, polyethylene, poly-propylene, aramid, glass, carbon, steel, ceramic, others. Globally, the participation of chemical fibers corresponds to approximately $59,9 \%$, and the synthetic fiber polyester, the most used one, represents approximately $63 \%$ of the world market. Vital needs have led to the development of multi-function fibers and the focus has changed in the last 10 years with the use of nanotechnology for environmental responsibility and smart fibers. The study of mechanical properties and fracture mechanisms of fibers is of great relevance for characterization and understanding of causes as consequence of failures. For such reason, it was selected technical fabrics made of high performance synthetic fiber nylon-and-polyester type, used in engineered products such as tires, belts, hoses and pneumatic springs, which have been analyzed in each processing phase. Fiber samples were extracted after each processing phase to be analyzed, by traction destructive tests and scanning electron microscopy. The results of analysis of mechanical properties showed loss of resistance to temperature and multi axial stress during fiber processing phase. Through microscopy tests, it was possible to find contamination, surface stains, plastic deformations, scaling, variations in the fracture faces of the filaments and analyze in the fiber-rubber interface, the level of adhesion. These irregularities and variations are caused during the stages of the process.
\end{abstract}




\section{INTRODUÇÃO}

\subsection{Histórico}

Em 1400 Christopher Columbus encontrou nativos do Haiti brincando com bolas feitas de um polímero natural obtido de árvores (Baker; Mead, 2000). Este material chamado de borracha natural tornou-se um importante produto após ser descoberto pelo americano Charles Goodyear que com a adição do enxofre descobriu acidentalmente em 1839 o processo de vulcanização, ou seja, a reação química da borracha natural para um elastômero por meio do enxofre sob a ação do óxido de chumbo $(\mathrm{PbO})$ ou condutor branco, o carbonato básico de chumbo $\left(2 \mathrm{PbCO}_{3} \cdot \mathrm{Pb}(\mathrm{OH})_{2}\right)$ e calor (Elias, 2003).

O primeiro polímero semicristalino foi originado a partir da celulose do algodão que, convertida em fibras, tem sido utilizada pelo homem desde os tempos pré-históricos. Desde então, estas fibras cresceram de forma relativamente fácil na qual muitas tentativas foram feitas para melhorar as suas propriedades têxteis. $\mathrm{O}$ inglês John Mercer descobriu em 1844 que o tratamento do algodão com soluções aquosas de soda cáustica (hidróxido de sódio) traz para as fibras melhoria na resistência, melhoria no tingimento e alto brilho. $O$ francês Louis Figuier demonstrou em 1846 que o papel da celulose era fortalecido com algodão quando tratado com acido sulfúrico. Nelson Goodyear usou maiores quantidades de enxofre na composição de seu irmão, Charles Goodyear e, em 1851, obteve Ebonite, um termofixo preto de elevada dureza. $O$ início da comercialização dos plásticos se deu em 1868 quando John e Isaiah Hyan plastificaram o nitrato de celulose e moldaram bolas de bilhar, e mais tarde pentes, escovas e outros artigos de uso (Deanin; Mead, 2003). As resinas fenólicas foram investigadas por Adolf von Baeyer em 1872, contudo, somente materiais resinosos.

O primeiro termofixo totalmente sintético foi inventado em 1906 pelo químico belga naturalizado americano Leo $\mathrm{H}$. Baekeland quando aqueceu vários fenóis com formaldeido sob pressão e produziu massas sólidas insolúveis. 
O resultante baquelite foi reconhecido em 1909 como um excelente isolante térmico e assim tornou-se uma das fundações da indústria elétrica moderna. Baekeland foi quem utilizou o processo de calor e pressão para produzir comercialmente materiais úteis (Elias, 2003). O plástico termofixo baquelite é irreversível, ou seja, não amolece quando é aquecido e permanece na sua forma original. Durante os 30 anos seguintes, uma variedade de plásticos surgiu na forma de especialidades interessantes. Em 1929, Carothers iniciou os estudos fundamentais sobre a polimerização e a formação de compostos cíclicos no laboratório da empresa E. I. du Pont de Nemours \& Co. O primeiro conjunto de estudos de Carothers refletiu em puro interesse cientifico, ao passo que Schlack e Kunz, mais tarde, focaram suas atenções em aplicações práticas (Evstatiev, 1997).

Durante a $2^{\mathrm{a}}$ Guerra Mundial, os componentes naturais ficaram tão escassos que a indústria de borracha foi forçada a desenvolver materiais sintéticos para substituí-los. Com base em necessidades tecnológicas da área militar, os governos dos Estados Unidos e da Alemanha iniciaram um vasto estudo para o desenvolvimento da manufatura de polímeros e aplicações de borracha. Com o final da guerra em 1945, toda a tecnologia e a capacidade de produção convertida para produtos de consumo e artigos de plástico deram início a um grande crescimento (Deanin; Mead, 2003). Primeiro o polivinil clorado e o poliestireno, depois o polietileno, polipropileno, poliésteres e poliuretano, junto com uma constante expansão de polímeros especializados para as mais variadas aplicações na área de engenharia.

O alvo do desenvolvimento de fibras sintéticas foi a imitação e substituição das fibras naturais. Na década de 60, os desenvolvimentos na área de engenharia, provocaram inovação aos processos, melhoria na qualidade e investimento de funções na produção de fibras polivalentes. Na década de 80 , fibras de alto desempenho foram desenvolvidas, como um grupo de fibras de carbono e fibras de aramida denominadas superfibras. Outras pesquisas foram conduzidas para desenvolvimento de fibras para elevadas funções e alta sensibilidade. Em 2004, termos tais como proteção ambiental, uso de fibras biodegradáveis, recicláveis e saúde, conforto e segurança têm sido adicionados ao desenvolvimento de novos materiais. 
Necessidades vitais têm conduzido a fibras multifuncionais e a atenção mudou, ao longo dos últimos dez anos, para a tecnologia de imitação do ecossistema (biomimética) para fibras de responsabilidade ambiental e fibras inteligentes.

O caminho em direção à Ciência da nanoescala teve início em 1905, quando Albert Einstein publicou um artigo estimando o diâmetro de uma molécula de açúcar em torno de $1 \mathrm{~nm}$ (Banerjee et al., 2005). Na atualidade, a nanotecnologia tem auxiliado na produção de nanofibras tecnológicas que são desenvolvidas para necessidades práticas. Como exemplo tem-se as nanofibras de nanotubos de carbono que têm sido produzidas quando o arranjo molecular de cadeias poliméricas é controlado em nível nano (Hongu et al., 2005). Nas Figuras 1 e 2 são mostrados, de forma esquemática, filamentos com micropartículas e nanopartículas com as cadeias moleculares controladas.

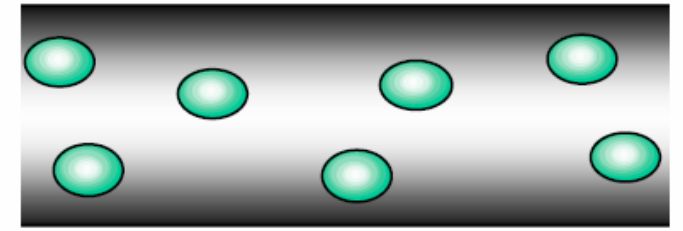

MICROPARTÍCULAS

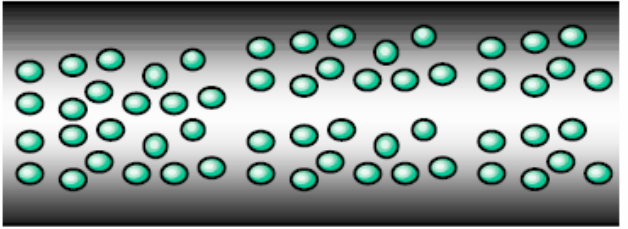

NANOPARTÍCULAS

Fonte: Tokamaki, 2003.

FIGURA 2. Nanopartículas

FIGURA 1. Micropartículas

Estudos recentes comprovam a facilidade de controle dos sistemas moleculares, os quais permitem inclusive o tratamento superficial de filamentos de fibras com o objetivo de proteção e o aumento de algumas propriedades físicas (Santos, 2004). Nas Figuras 3 e 4 são mostrados filamentos de fibra de náilon 6.6 sem e com revestimento de nano $\mathrm{TiO}_{2}$ (Mecheels, 2005).

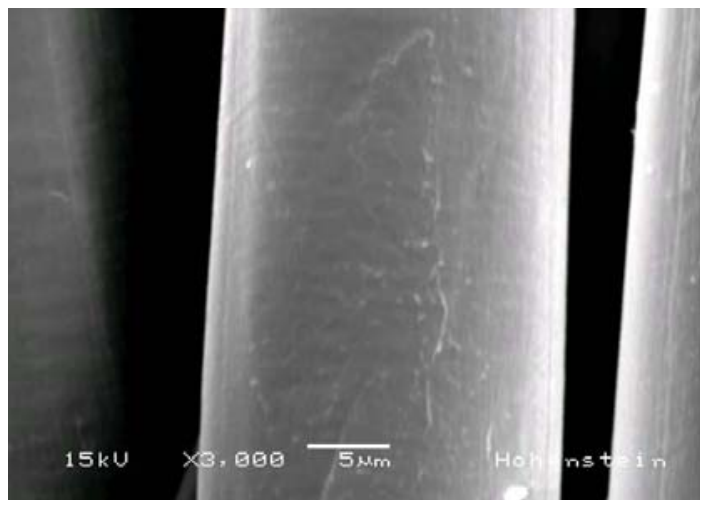

FIGURA 3. Filamento sem revestimento

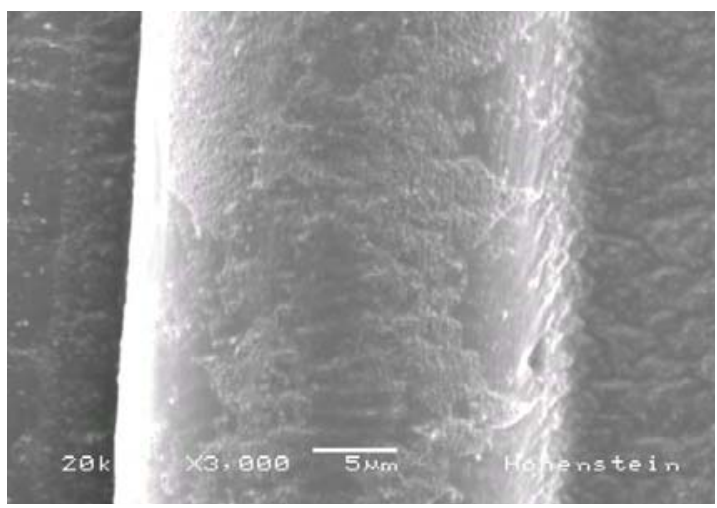

Fonte: International Congress of Nanotechnology, 2005. FIGURA 4. Filamento com $2 \%$ revestimento 


\subsection{Objetivos}

\subsubsection{Objetivos Gerais}

A análise de falha de têxteis é uma área especial fascinante de testes destes materiais. Tem significativa relevância prática, considerável atrativo, mas também muitas dificuldades. Determinar a exata causa da falha pode muitas vezes ser um real desafio. Aqueles que procedem à análise da falha precisam não somente de um amplo conhecimento e alguma experiência, mas também de intuição e habilidade para raciocinar e levantar evidências. Portanto, a base principal é o conhecimento e o entendimento da tecnologia têxtil, incluindo a física e a química têxtil. É necessária a utilização de métodos essenciais usados na análise da falha, tais como microscopia, cromatografia, espectroscopia por infravermelho (IR) e análise térmica. Em muitos casos diversos testes diferenciados são necessários e seus resultados podem ocasionalmente ser contraditórios. Então estes testes têm de ser avaliados e ponderados utilizando-se de métodos de comparação mútua, bem como a comparação de amostras, experiência com casos similares e informação sobre as circunstâncias da falha podem ser extremamente úteis (Schindler; Finnimore, 2005).

Portanto, o trabalho proposto pretende estudar os mecanismos de deformação e fratura de fibras do tipo náilon e poliéster, compostos de filamentos, sujeitos ao carregamento do tipo tração, torção, flexão, compressão e impacto; inclusive com exposição à temperatura e tensões multiaxiais, ou seja, conjugadas entre si, durante as suas etapas de processamento.

\subsubsection{Objetivos Específicos}

$\mathrm{Na}$ literatura é raro encontrar trabalhos que contemplem com uma metodologia cientifica definida, tanto a variação das propriedades mecânicas de fibras de alto desempenho durante o processo de fabricação, como os mecanismos de fratura dessas mesmas fibras associadas entre si. 
O trabalho se baseia no princípio de que o mecanismo de fratura de um conjunto de fibras, cada uma composta de dezenas de filamentos, ocorre de forma heterogênea. Em resumo e com base em elementos que compõem este trabalho de pesquisa, a seguir são listados os itens que caracterizam a importância do presente estudo:

- Estudar os parâmetros de resistência mecânica das fibras do tipo náilon e poliéster;

- Estudar os parâmetros de resistência mecânica dos tecidos com fibras do tipo náilon e poliéster;

- Estudar a redução da resistência das fibras sujeitas a tensões multiaxiais;

- Entender o mecanismo de fratura destas fibras e tecidos;

- Estudar as propriedades mecânicas e os perfis de fratura para as fibras de náilon e poliéster, inclusive as propriedades de adesão interfacial para estes materiais.

\subsubsection{Escopo da pesquisa}

Os objetivos apresentados anteriormente sugerem o contexto deste trabalho. Têm-se como centro de pesquisa a produção de quatro amostras de correias transportadoras de granulados denominadas com as letras "A e B" (reforço estrutural do tipo náilon) e letras "C e D" (reforço estrutural do tipo poliéster). Cada etapa de fabricação é acompanhada e amostras dos tecidos e das fibras são extraídas para análise das propriedades e dos mecanismos de fratura, sendo os resultados obtidos por ensaios de resistência mecânica (monitorado e convencional) e microscopia eletrônica de varredura. 
O tópico principal da pesquisa é o estudo de um conjunto de fibras compostas de multifilamentos, que são utilizadas para confecção de tecidos técnicos de engenharia, os quais têm em sua composição o náilon e o poliéster utilizados em correias transportadoras de granulados.

\subsubsection{Contribuição científica}

Em função da crescente aplicação das fibras sintéticas na indústria de um modo geral, e em particular na utilização destas como reforço estrutural em elementos dinâmicos que exigem resistência mecânica elevada com fator de segurança alto, a originalidade deste projeto de pesquisa é analisar e entender o mecanismo de fratura e a variação das propriedades das fibras do tipo náilon e poliéster utilizadas em correias transportadoras de granulados.

Um outro ponto importante a ressaltar é que, devido a similaridade nos processos de fabricação das fibras e tecidos de um modo geral, as informações obtidas no presente estudo são aplicáveis a outras construções e projetos destinados a outros produtos de engenharia; que não são somente correias transportadoras. 


\section{REVISÃO BIBLIOGRÁFICA}

\subsection{Aplicações de engenharia}

Materiais a granel são transportados desde o final do século XVIII. A maioria das instalações manipulava grãos por distâncias relativamente curtas. Os primeiros sistemas eram muito primitivos e a sua formação era basicamente de correias confeccionadas com couro, lona ou borracha que se movimentavam sobre uma superfície livre plana ou estrutura de madeira. Este tipo de sistema não era o mais avançado da época, mas promoveu o incentivo para que os engenheiros o considerassem como um método rápido, econômico e seguro para movimentação de grandes volumes de materiais a granel de um local para o outro.

No ano de 1920, mostrou-se que o sistema podia ser utilizado para transportes a longa distância. Algumas das instalações eram subterrâneas e manipulavam minério de carvão a uma distância equivalente a $8 \mathrm{~km}$. Os materiais utilizados na confecção da correia eram constituídos de múltiplas lonas de pano de algodão e coberturas de borracha natural, que eram os únicos materiais fabricados naquela época. Embora antiquado, comparado aos processos de hoje, este sistema de manipulação de material foi considerado preferencialmente como um meio de transporte, provando ser bastante apropriado para este fim.

Hoje, estas indústrias produzem correias com uma gama quase que infinita de polímeros e tecidos para satisfazer as exigências de projeto para qualquer tipo de situação de carregamento imposta. Inúmeras aplicações para este sistema de transporte aumentaram consideravelmente desde 1920, sendo inúmeras as vantagens, se comparado a outros meios de transporte, tais como caminhão, vagões em estrada de ferro, entre outros (Goodyear, 2000). Na figura 5 é mostrado, de forma esquemático, um sistema transportador identificando os pontos de solicitação dinâmica. 


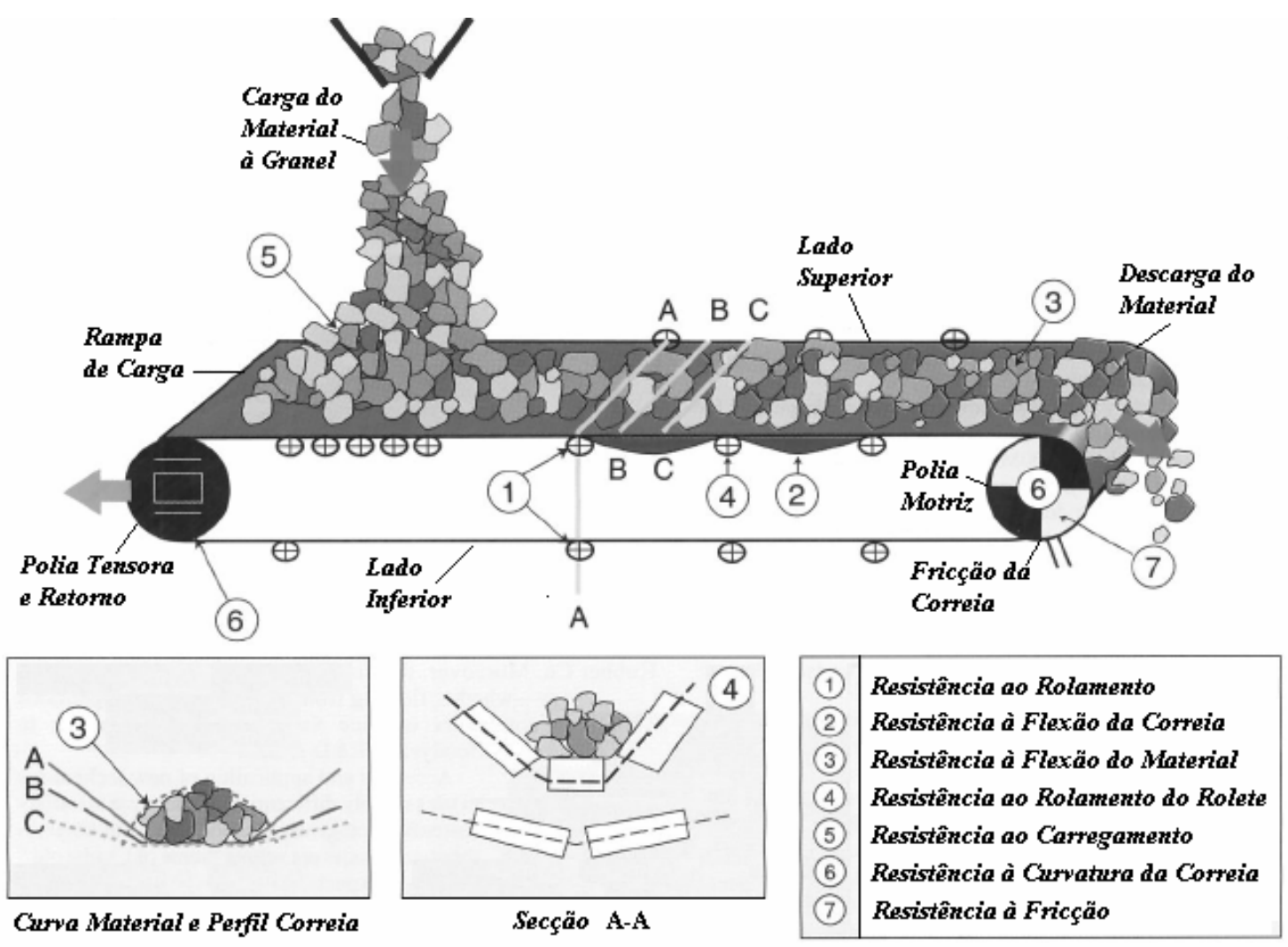

FIGURA 5. Sistema transportador

Atualmente, sistemas transportadores são utilizados nas mais diversas áreas, que abrangem caixas, fertilizantes, frutas, granulados leves como soja, milho, açúcar, arroz, granulados pesados como minério de ferro, urânio, manganês, bauxita, cobre, carvão, pedras, entre outras. Nas figuras 6 e 7 são mostrados sistemas transportadores de minério de urânio e minério de carvão.

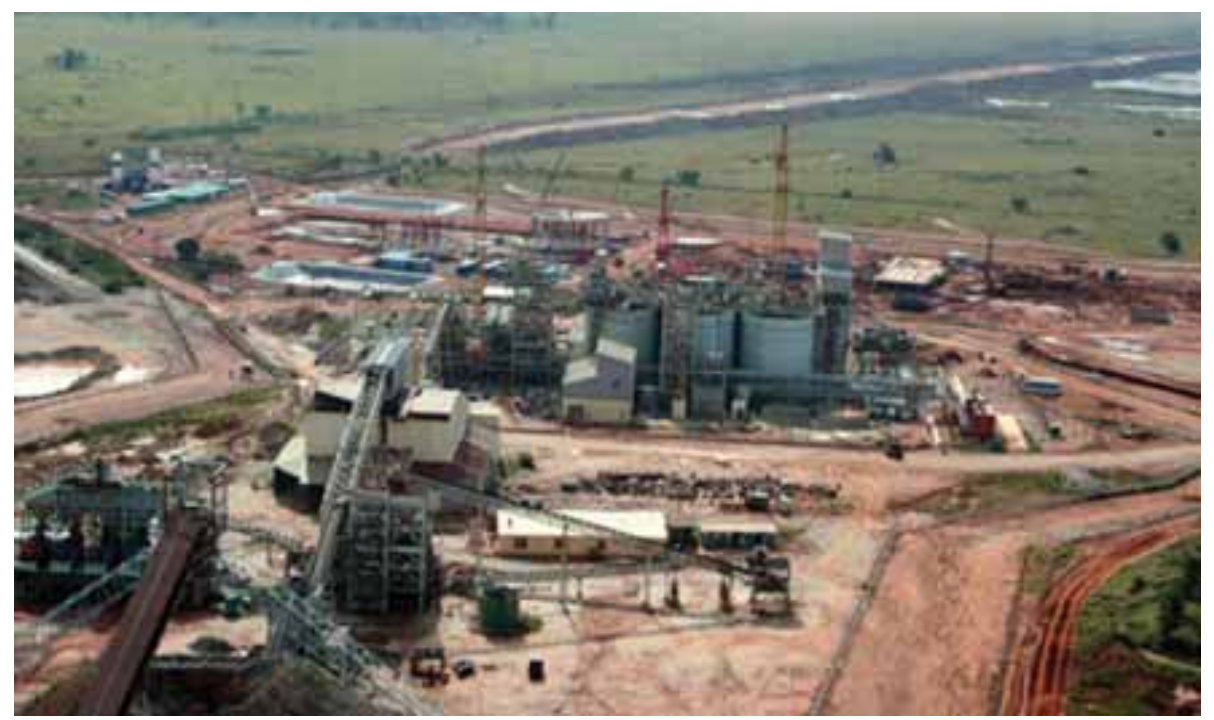

Projeto Domínio em Klerksdorp África do Sul

FIGURA 6. Sistemas transportadores para britagem do minério de urânio 


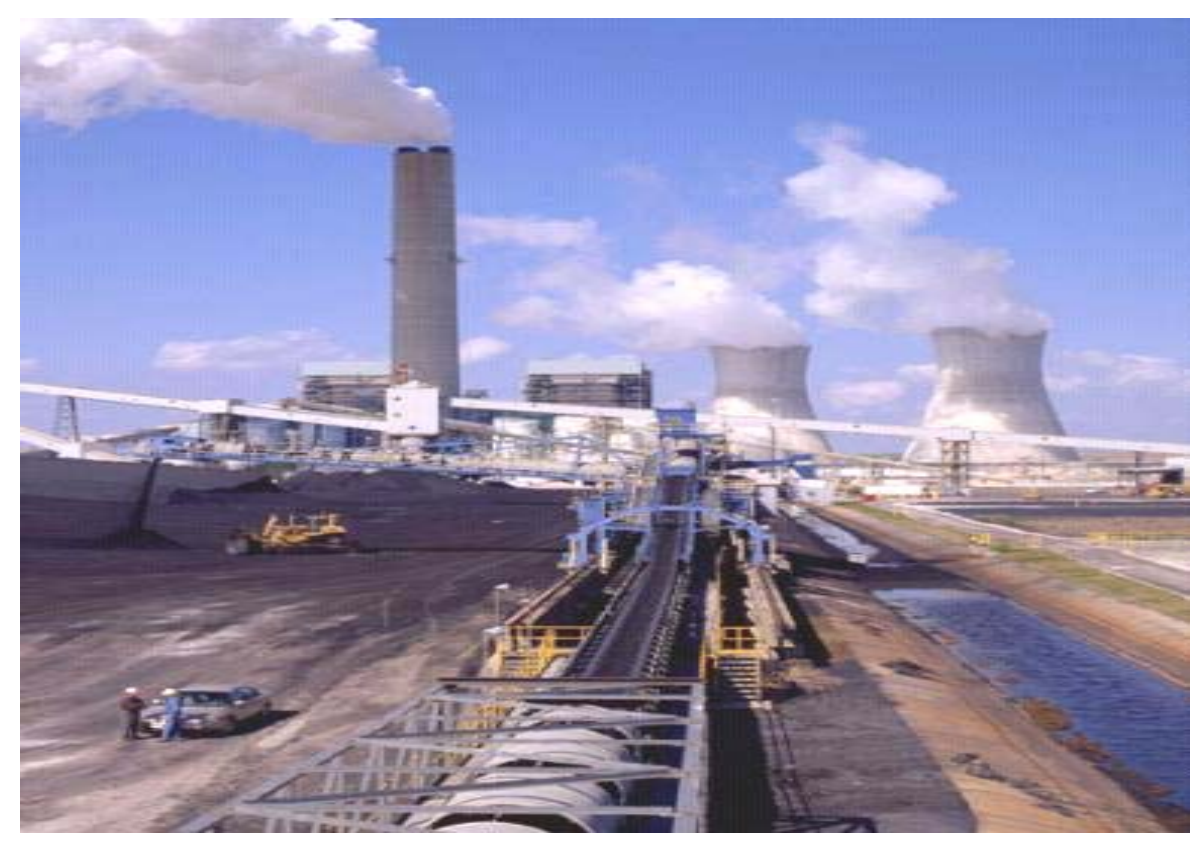

Usina de geração de energia em Winfield - Virginia Ocidental USA

FIGURA 7. Correia transportadora de carvão para geração de energia

Os tecidos de engenharia são fabricados valendo-se de fibras sintéticas ou naturais utilizados em aplicações que requerem altas resistências físicas e mecânicas. Como exemplo, mesmo os tecidos utilizados em assentos de automóveis, que são fabricados de fibras de poliéster com quantidades relativamente pequenas de náilon, lã e acrílico, requerem algumas propriedades específicas tais como resistência mecânica, térmica e à fadiga. A fibra de acrílico é usada no teto de automóveis conversíveis devido a sua excelente resistência às intempéries e à degradação por raios ultravioleta. A lã continua sendo usada em automóveis luxuosos que exigem as mesmas propriedades específicas.

Os métodos de processamento, máquinas e materiais usados variam de acordo com o tipo de fibra e a construção do tecido. Segundo Fung e Hardcastle (2001), uma exigência fundamental é que o tecido tenha elasticidade consistente, bem como uma aparência boa e uniforme, pois se trata de propriedades de resistência e estética para o assento do automóvel. As fibras são normalmente lubrificadas em vários estágios do processamento para reduzir a eletricidade estática e para ajudar na melhoria da eficiência nas etapas de torção, texturização, urdidura e tecelagem. Nas Figuras 8 e 9 são mostrados o tipo de tecido e a sua aplicação em uma correia transportadora com estrutura composta de cinco componentes têxteis, sendo as fibras no sentido transversal chamadas de trama e as fibras no sentido longitudinal chamadas de urdume (Goodyear, 2000). 

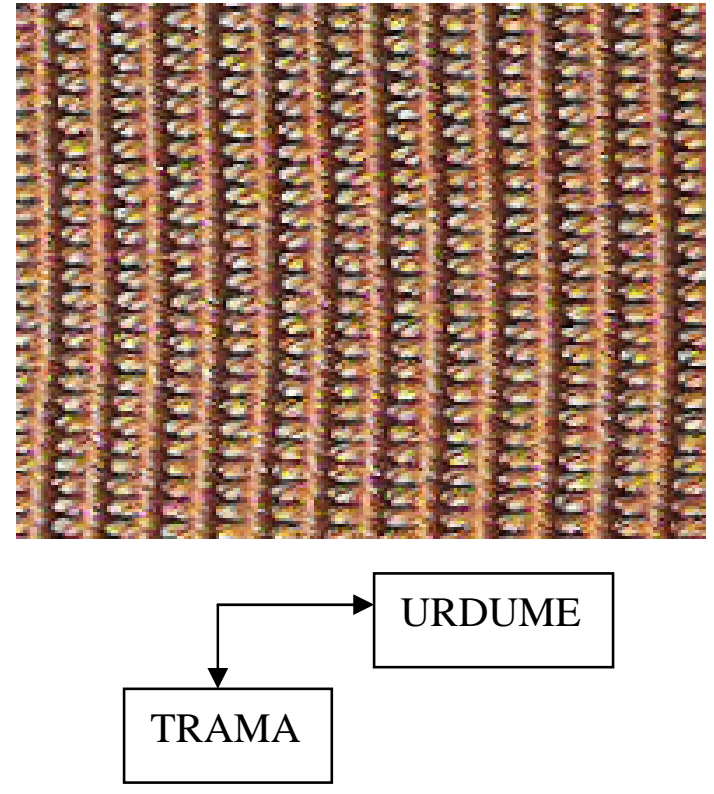

FIGURA 8. Tecido

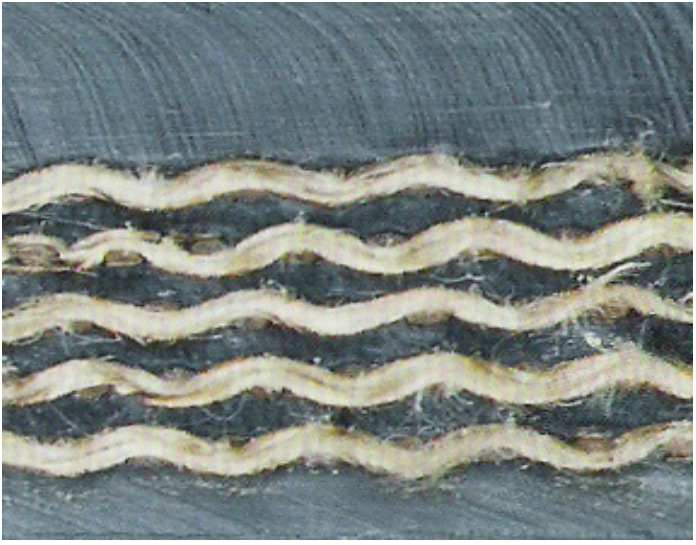

URDUME

TRAMA

Entre diversas aplicações que utilizam tecidos de engenharia podem-se citar outros exemplos em nível industrial, tais como: pneus, mangueiras para condução de petróleo e molas pneumáticas conforme Figuras 10 a 12 (Goodyear, 2000).

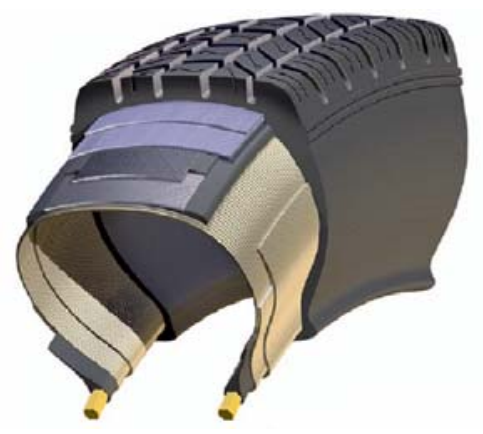

FIGURA 10. Pneu

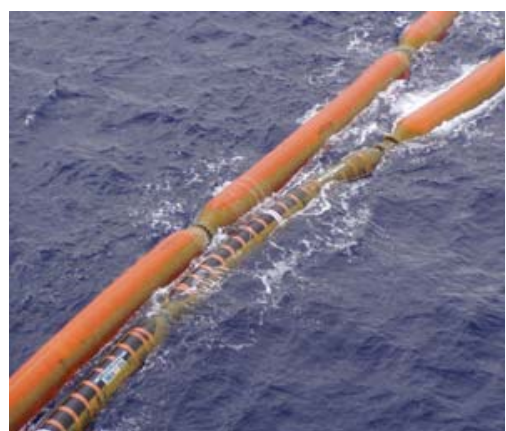

FIGURA 11. Mangueira

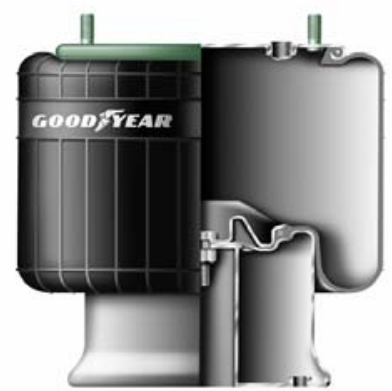

FIGURA 12. Mola pneumática

Os materiais de construção da parte estrutural de tecidos para aplicações de engenharia são basicamente compostos de fibras de alto desempenho, produzidas com base em materiais poliméricos (Cardoso et al., 2005).

\subsubsection{Materiais Poliméricos}

Os materiais poliméricos são utilizados como matéria-prima para a fabricação de fibras de alto desempenho. A palavra polímero origina-se do grego poli (muitos) e mero (unidade de repetição). Assim, um polímero é uma macromolécula composta por muitas (dezenas de milhares) unidades de repetição, ligadas por ligação covalente. 
A matéria-prima para a produção de um polímero é o monômero, isto é, uma molécula com uma unidade de repetição (mono). Dependendo do tipo de monômero (estrutura química), do número médio de meros por cadeia e do tipo de ligação, pode-se dividir os polímeros em três grandes classes: plásticos, borrachas e fibras (Canevarolo, 2002).

Nas Figuras 13 e 14, observa-se um mecanismo de polimerização por adição do etileno no qual a ligação dupla original do monômero etileno é quebrada para formar ligações simples e, portanto, ligar meros adjacentes (Vlack, 2002).

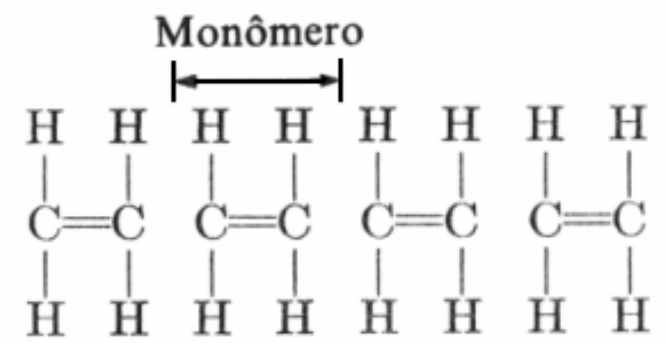

(a)

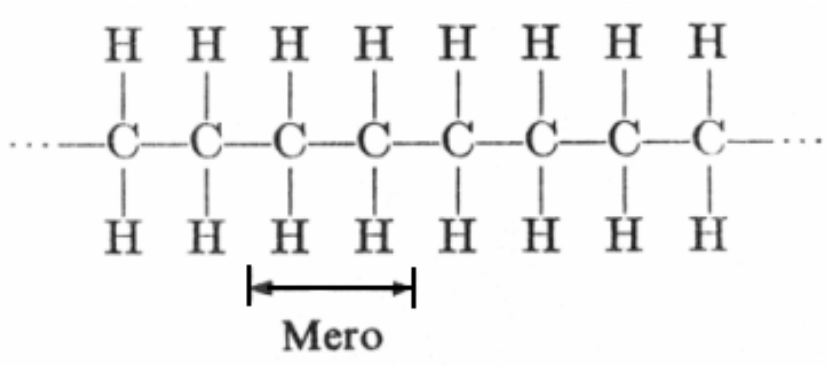

(b)

Fonte: Vlack, 2002.

FIGURA 13. Monômeros de etileno

FIGURA 14. Polímeros $\mathrm{C}_{2} \mathrm{H}_{4}$ (meros)

Os materiais plásticos são mais densos que os materiais de borracha e, a temperatura baixa, suas propriedades são inferiores. Geralmente, plásticos diferem de materiais de borracha em razão da temperatura de transição vítrea $\left(T_{g}\right)$. $O$ plástico tem a $T_{g}$ acima da temperatura ambiente, ao passo que a borracha terá a $\mathrm{T}_{\mathrm{g}}$ abaixo da temperatura ambiente. $\mathrm{A} \mathrm{T}_{\mathrm{g}}$ é mais claramente definida avaliando o comportamento do módulo elástico em relação à temperatura do polímero. Em temperaturas baixas, o material pode ser descrito melhor como sólido vítreo (Baker; Mead, 2000).

A principal vantagem dos materiais plásticos é a facilidade de substituição de materiais convencionais e o desenvolvimento de produtos antes considerados impossíveis de confecção. Foster (2002) citou a evolução das fibras utilizadas em cordas, as quais possuem resistência até um ponto em que chegam a substituir cabos de aço em diversas aplicações. O maior fator tem sido o desenvolvimento de fibras de tenacidade alta e os avanços na construção de cordas produzidas com estas fibras. 
A poliamida e o poliéster industrial, originalmente utilizados em fibras para pneus, são produzidos com tenacidades e propriedades importantes para aplicações em cordas. Aplicações estas que reduzem danos por terremotos, nos quais se estudam as solicitações dinâmicas da ancoragem com a estrutura no intuito de dissipar energia e absorver movimento. A primeira ancoragem feita com corda em poliéster de alta tenacidade foi instalada no Golfo do México, operando a uma profundidade de 1.916 metros (Foster, 2002).

Segundo Peters (2002), o desenvolvimento de polímeros sintéticos na forma de plásticos, fibras, elastômeros, adesivos e revestimentos podem entrar em cena como resultado da pesquisa para substâncias artificiais e sintéticas, que podem ter melhor desempenho ou ser produzidas a custo baixo, se comparadas a materiais naturais tais como madeira, vidro e metal, os quais requerem mineração, refino, processamento, moagem e usinagem.

Para o projeto de componentes plásticos é necessário ter informações completas, assim como é relevante a temperatura de trabalho, no comportamento dependente do tempo (comportamento viscoelástico) do material ao longo de toda a gama de tensões a ser aplicada ao componente (Chanda; Roy, 2006).

É importante identificar o grau de orientação molecular bem como o grau de cristalinidade, uma vez que fornecem informações úteis em relação aos parâmetros de desempenho e processo, tais como tensão, módulo de elasticidade e relação de umidade. Contudo, existem plásticos, em particular resinas plásticas, que não têm nenhuma deformação nem elasticidade e ainda são extremamente resistentes.

O estudo de materiais têxteis envolve uma imensa gama de fibras químicas e a sua formação no processamento. Isto abrange a multiplicação de diferentes técnicas para a preparação e produção de tecidos para o vestuário humano e tecidos técnicos altamente especializados, incluindo o seu eventual acabamento, reciclagem e propriedade física. Algumas destas considerações são específicas da fibra, uma vez que algumas são mais direcionadas para o método de formação do tecido. Os diferentes tipos de cadeias de polímeros têxteis podem ser classificados em isotáticos, sindiotáticos e atáticos (Canevarolo, 2002). 
Na figura 15 é mostrada a classificação das cadeias para o polipropileno.

ISOTÁTICO

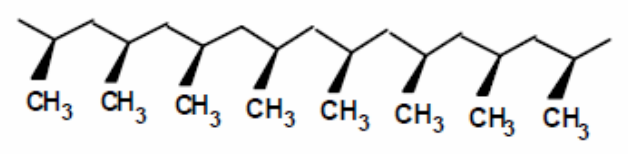

$\left[\begin{array}{cc}\stackrel{\mathrm{I}}{\mathrm{H}} & \stackrel{\mathrm{C}}{\mathrm{C}} \\ \mathrm{H} & \mathrm{CH}_{3}\end{array}\right]_{\mathrm{n}}$

POLIPROPILENO
SINDIOTÁTICO

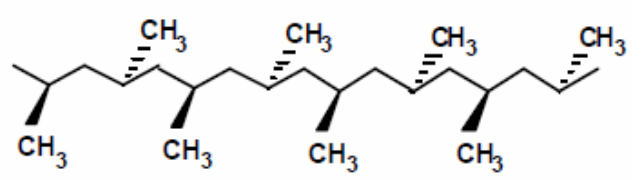

ATÁTICO

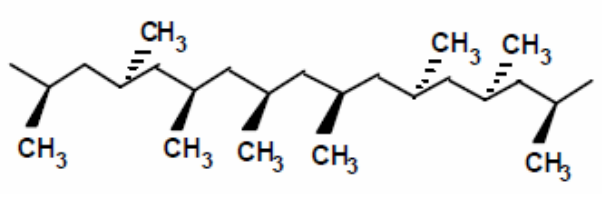

FIGURA 15. Classificação das cadeias para o polipropileno

Para a presente aplicação, provavelmente a característica mais significativa de polímeros têxteis é o seu anisotropismo. Certamente, poderia até ser usado como argumento que se o polímero não exibe anisotropismo, não é da família de produtos que podem ser descritos como têxteis. Talvez a razão lógica para iniciar a investigação de polímeros têxteis seja a indagação da isotropia. Orientação molecular e cristalinidade não são, é claro, a mesma coisa, mas o efeito de ambas sobre a forma como desempenha um polímero é frequentemente difícil de distinguir.

\subsubsection{Fibras}

Segundo Canevarolo (2002), no aspecto geral, uma fibra é definida como um conjunto de filamentos poliméricos orientados com a direção principal das cadeias posicionadas paralelas ao sentido longitudinal (eixo maior). Fibras são definidas como unidades de matéria caracterizadas pela flexibilidade, excelência e alta relação dimensional devendo satisfazer a condição geométrica de o comprimento ser no mínimo cem vezes maior que o diâmetro $(1 / d>100)$.

$\mathrm{O}$ conjunto de filamentos de uma fibra forma um cilindro de diâmetros irregulares ao longo do seu comprimento. Essa irregularidade torna impossível a medição do diâmetro, mesmo com o auxílio de aparelhos micrométricos. Devido a esta dificuldade, foi então criada uma forma de expressar o diâmetro do fio, o que ficou conhecido como titulação. 
Existem duas unidades de medida utilizadas para determinação do título da fibra, o denier e o tex, sendo o tex o mais utilizado mundialmente e recomendado pelo Sistema Internacional de Unidades (SI). Segue abaixo as equivalências destas unidades (Pereira, 2005):

- Denier equivale ao peso em gramas de 9000 metros de fibra;

- Tex equivale ao peso em gramas de 1000 metros de fibra;

- Dtex equivale ao peso em gramas de 10000 metros de fibra.

As fibras devem ter força suficiente para resistir à ruptura devida à tensão aplicada durante a manufatura e o uso, inclusive possuir estabilidade térmica e química suficiente para resistir ao ambiente ao qual estão expostas. Além disso, um alongamento de 5 - 50\% é requerido, dependendo da utilização final do produto. Até a introdução das fibras sintéticas e artificiais no mundo, todos tinham que recorrer às fibras de recursos naturais. Nem todas estas fibras foram adequadas a serem utilizadas como fibras têxteis, porque faltavam a elas algumas características, por exemplo, muitas nem chegaram a ser flexíveis ou suficientemente fortes. Solo, alimentos para animais e outras condições climáticas e ambientais afetam as fibras naturais, resultando em propriedades instáveis. Fibras sintéticas e artificiais não são muito influenciadas por estes fatores e um controle maior pode ser exercido durante a sua produção. Entretanto, mesmo com controle maior, ligeiras variações na produção de fibras sintéticas e artificiais podem dar origem a variações significativas na coloração, resistência e outras propriedades.

Cada fibra individual é fabricada tomando-se por base milhões de longas cadeias moleculares individuais de estrutura química discreta. A morfologia, isto é, o arranjo e orientação destas moléculas dentro da fibra individual, bem como a secção transversal total e a forma, influenciam as propriedades da fibra. Entretanto, as características físicas e químicas em grande parte dependem da estrutura química das longas cadeias moleculares que constituem a fibra. O número total de unidades de repetição na cadeia varia de poucas unidades a várias centenas e é designado como o grau de polimerização (degree of polymerization, DP) para moléculas no interior da fibra. O algodão, por exemplo, tem um DP de 10.000 e o raiom viscose, uma fibra artificial, tem um DP de 300 - 350. O DP de fibras sintéticas e artificiais é determinado por vários fatores durante a produção destas fibras (Choudhury, 2006). 


\subsubsection{Classificação das fibras}

Fibras são amplamente divididas em duas classes: naturais e químicas. Fibras naturais podem ser obtidas de fontes vegetais, animais e minerais. As fibras vegetais podem ser divididas em até vários subgrupos, dependendo da parte da planta da qual a fibra é extraída. Fibras químicas podem ser subdivididas em três subclasses:

- Fibras artificiais, como o raiom viscose e o raiom acetato;

- Fibras sintéticas, como poliéster, náilon (poliamida), poliuretano (Spandex), polivinil, hidrocarbono polimerizado ou poliolefinas (polipropileno) e borrachas sintéticas;

- Fibras refratárias (cerâmicas) e industriais, como carbono, vidro, metal, entre outras.

Na Tabela 1 é apresentada a cadeia têxtil com as principais fibras naturais e químicas.

TABELA 1. Cadeia têxtil das principais fibras

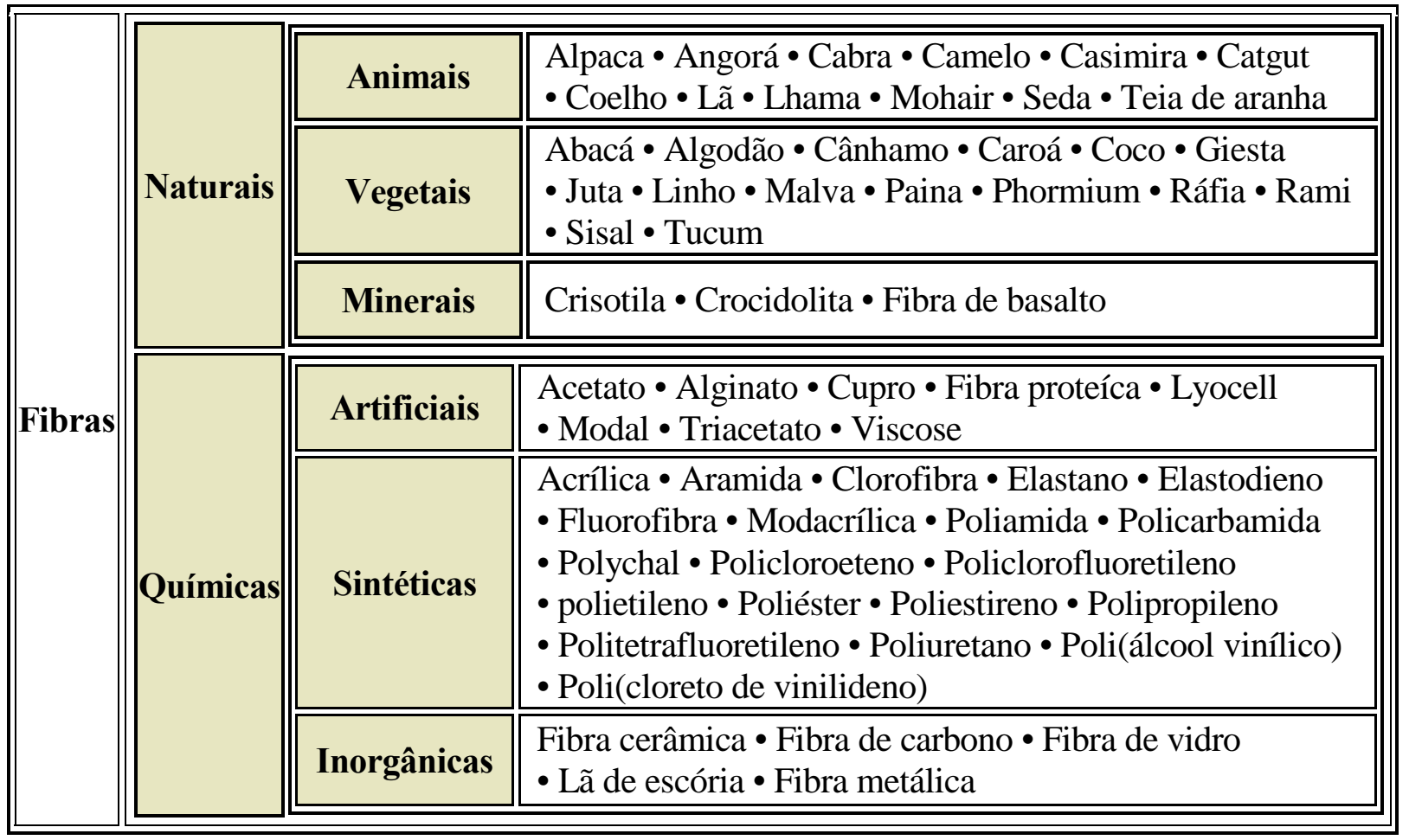

As duas fibras mais importantes em nível global são a celulósica (algodão) e o poliéster, significando algo em torno de $62,8 \%$ do consumo mundial. Estima-se que em 2010, o consumo do poliéster será maior que o de fibras celulósicas. 


\subsubsection{Fibras artificiais}

São fibras produzidas a partir da matéria-prima natural, como a celulose. O raiom de viscose foi o resultado da primeira corrida humana para imitar a natureza na produção de seda como fibras contínuas por intermédio de um orifício. Celulose da polpa da madeira é o principal constituinte deste novo sistema, iniciado comercialmente em 1920. A viscose ignífuga com propriedades antichama foi a primeira introduzida em 1960 (Miraftab, 2000).

\subsubsection{Fibras sintéticas}

São todas as fibras originadas do carvão ou do petróleo. A primeira fibra sintética que surgiu no mercado mundial em 1939 foi o náilon 6.6. Ele foi produzido pela DuPont e rapidamente adquiriu aprovação pública. Uma série de náilons, geralmente denominada poliamidas, é caracterizada pela cadeia de ligação de amidas. Náilon 6.6 e náilon 6 são mais populares em forma de fibras. Eles são extrudados a quente em uma variedade de formas geométricas e projetados para alcançar a tenacidade desejada.

\subsubsection{Processamento de fibras}

As fibras são processadas por extrusão, que consiste em pressionar a resina polimérica, em forma pastosa, por meio de furos finíssimos numa peça denominada fieira. Os filamentos que saem desses furos são imediatamente solidificados, processo denominado fiação. Na figura 16 são mostrados alguns dos tipos de tecidos confeccionados com fibras.

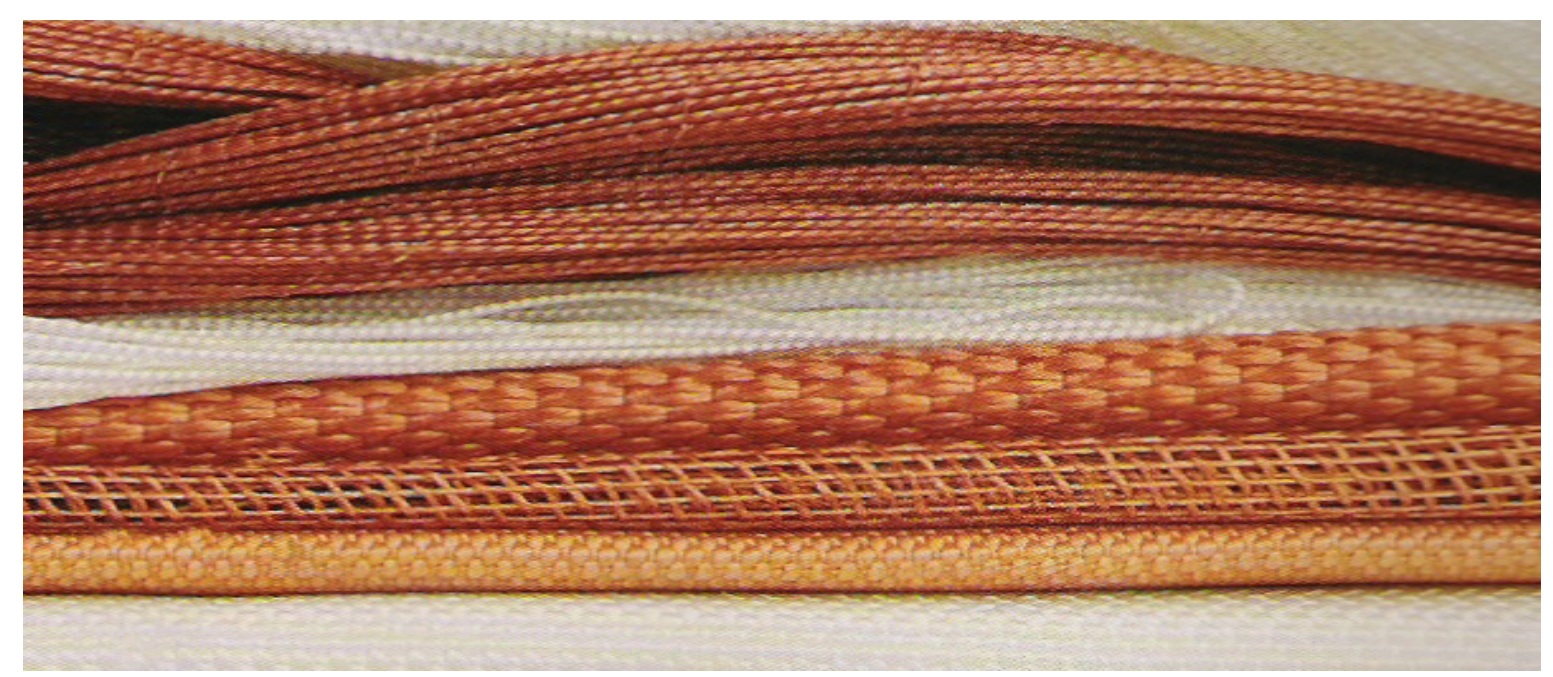

FIGURA 16. Tecidos com fibras 
As fibras tomam sua forma final por meio de estiramento, realizado mediante dois processos básicos: no primeiro, as fibras são estiradas durante o processo de solidificação; no segundo, o estiramento é feito após estarem solidificadas. Em ambos os casos, após o estiramento, o diâmetro e alongamento da fibra são reduzidos e a sua resistência à tração é aumentada.

As formas das fibras podem ser apresentadas em três classes distintas, destinadas a usos também distintos: monofilamento, filamento e fibra cortada (Chopped Fiber). O monofilamento, como o próprio nome indica, é um único filamento contínuo. O filamento é um fio continuo que, em quantidade, dá forma a uma fibra. A fibra cortada é resultado do seccionamento, em tamanhos determinados, de um grande feixe de filamentos contínuos.

Originalmente vindo da tecnologia aeroespacial, o plástico reforçado com fibra ou, como é conhecido, FRP (fiber reinforced plastic), hoje é usado com êxito para várias aplicações, por causa de suas excelentes propriedades específicas: resistência e dureza altas, peso baixo e potencial de otimização por orientação das fibras (espessura contínua) ao longo da direção de carregamento. A qualidade boa das propriedades associadas ao peso é devida à densidade baixa dos sistemas da matriz aplicada (poliéster insaturado, poliuretano, fenólico ou resinas epóxi) e às fibras unidas à matriz, resultando alta resistência e dureza (vidro, kevlar e fibras de carbono) (Riedel et al., 1998).

Nas Figuras 17 a 19 são mostrados os sistemas básicos de classificação, configuração e a produção das principais fibras têxteis artificiais. 


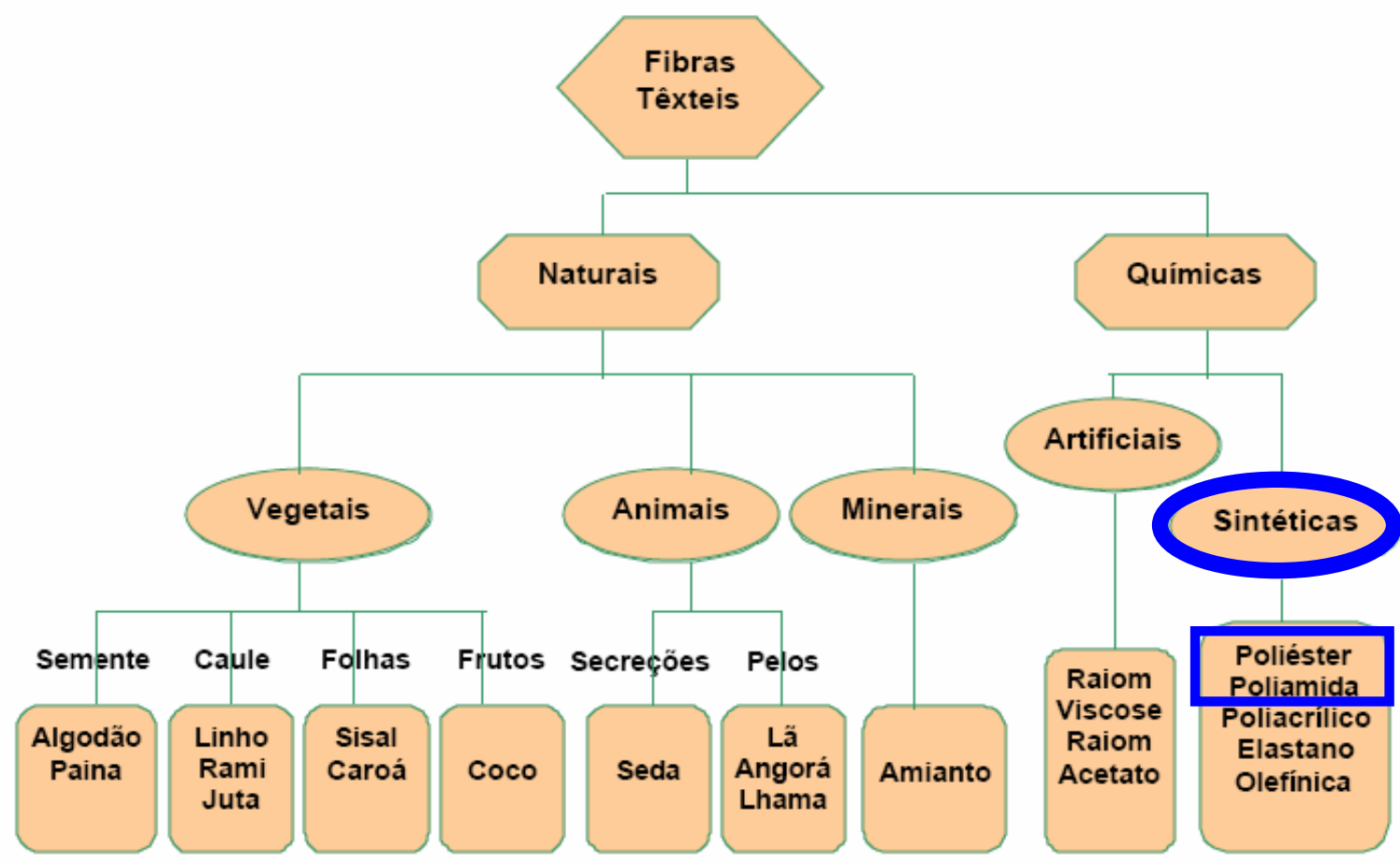

Fonte: Associação Brasileira de Produtores de Fibras Artificiais e Sintéticas, 1999.

FIGURA 17. Classificação das fibras têxteis

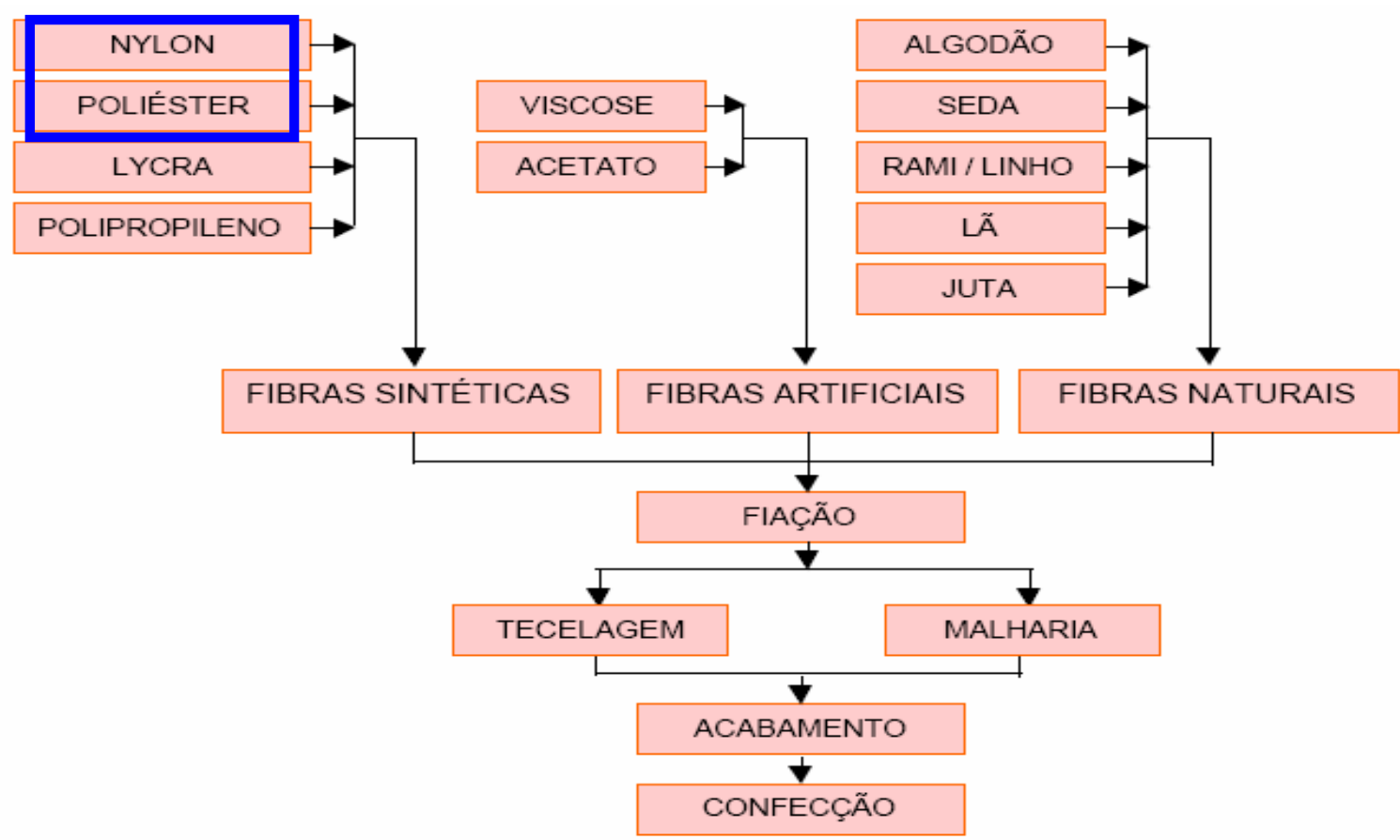

Fonte: Sindicato das Indústrias de Tecelagem de Americana, 2001.

FIGURA 18. Configuração básica da cadeia têxtil 


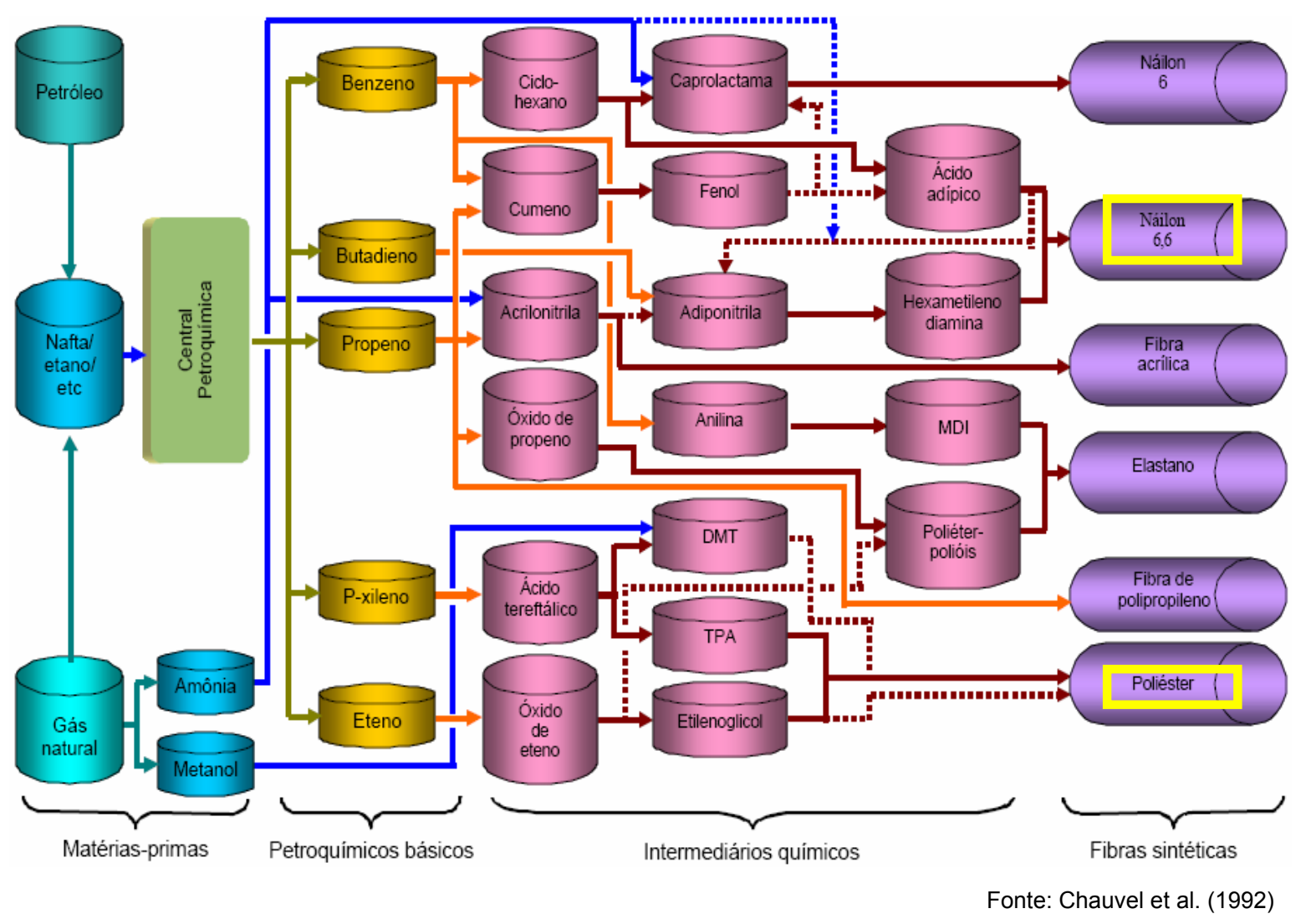

[. - . . Rotas alternativas para obtenção do mesmo produto ou equivalentes

FIGURA 19. Fluxograma da cadeia de produção das principais fibras sintéticas

\subsubsection{Panorama mundial de fabricação de fibras}

As primeiras fibras sintéticas começaram a ser produzidas em torno de 1950, e, a partir da década de 60, tiveram um crescimento constante, até superarem, por volta de 1965, as fibras artificiais ou celulósicas raiom viscose e raiom acetato (produzidas a partir da celulose). Por volta de 2000 , as fibras sintéticas igualaram-se às fibras naturais provenientes de plantas, tais como algodão, linho, lã, juta, cânhamo, seda e rami. Este comportamento e o crescimento constante das fibras sintéticas a partir da década de 80 é mostrado na Figura 20. 


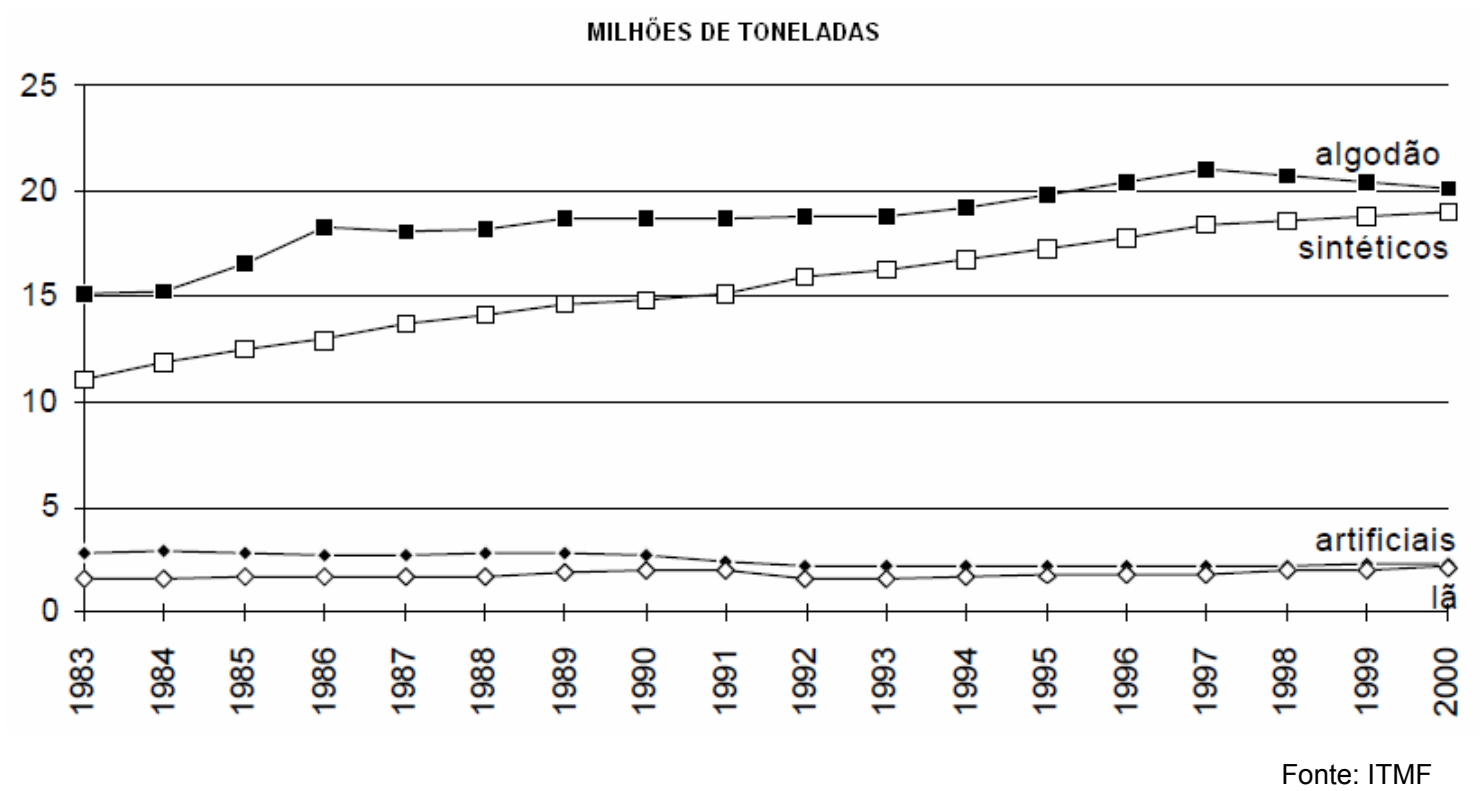

FIGURA 20. Produção mundial de fibras têxteis

Segundo a Fundação Getúlio Vargas (1999), devido ao fator competitividade, a parcela de utilização das fibras químicas pelas empresas têxteis, no Brasil vem ampliando-se. Em 1990, a proporção de utilização entre fibras químicas e fibras naturais era de aproximadamente $28 \%$ e $72 \%$, respectivamente. Em 1997, a proporção era de aproximadamente $38 \%$ para fibras químicas e $62 \%$ para naturais. Se incluirmos o polipropileno nas fibras químicas, esta participação passa a ser de 50\%. Barbosa et al. (2004) citou que o poliéster representa $62,8 \%$ do mercado mundial das fibras têxteis.

Cabe ressaltar que, até o ano de 2004, a participação das fibras químicas no mercado mundial era de $59,9 \%$ contra $40,1 \%$ para as fibras naturais, conforme é mostrado na Figura 21. 


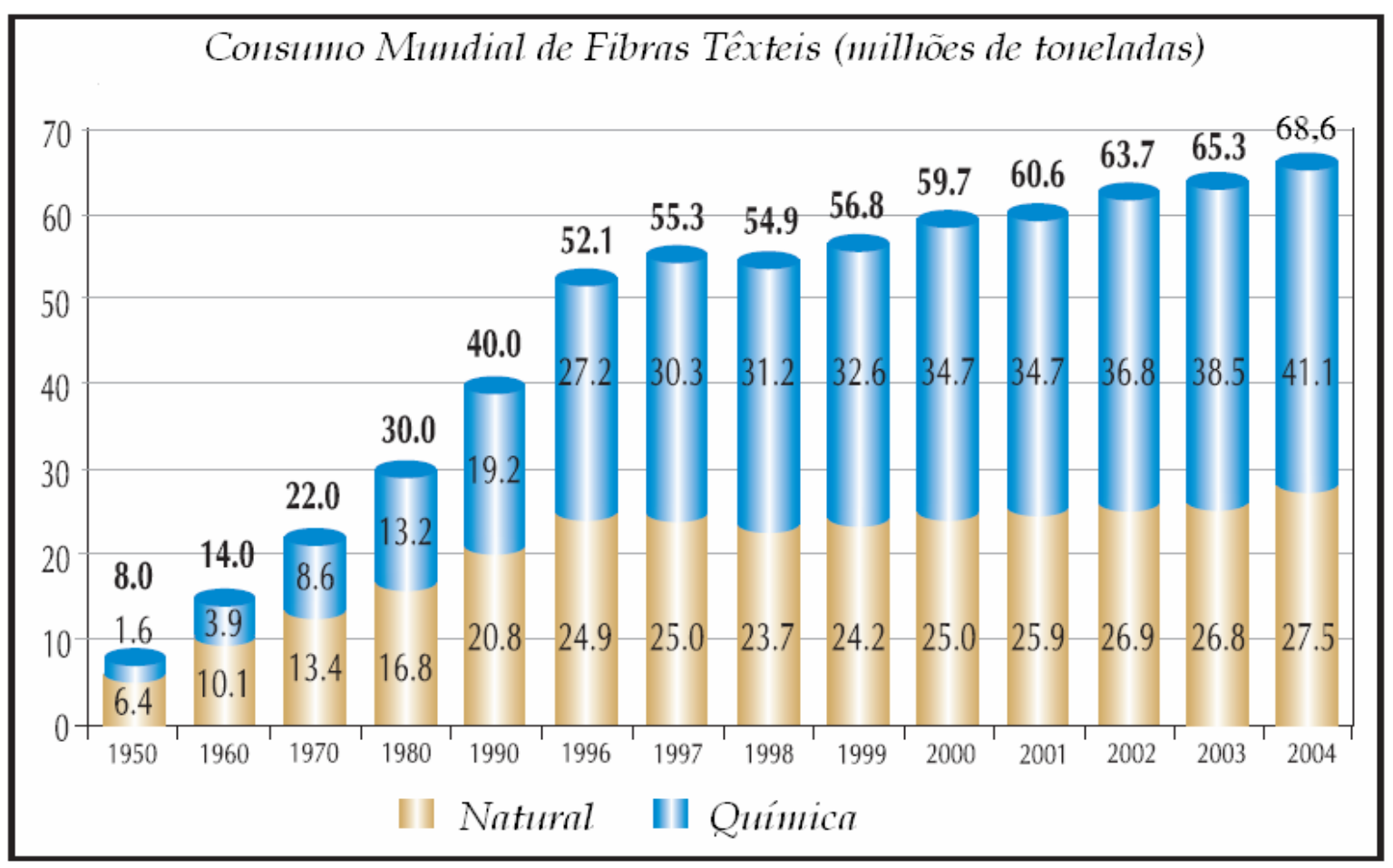

Fonte: Fiber Organon

FIGURA 21. Consumo mundial de fibras têxteis

O crescimento das fibras sintéticas acontece em razão, basicamente, das incertezas inerentes à produção das fibras naturais (algodão e linho, sobretudo), sujeitas às variações climáticas, de safra, de preços, entre outras, e dos aperfeiçoamentos obtidos na produção de fibras sintéticas, que as tornam cada vez mais próximas das naturais.

\subsubsection{Fibras de alto desempenho}

Fibras de alto desempenho são direcionadas para funções técnicas especiais que requerem propriedades físicas específicas e únicas para cada uma destas funções. Estas fibras são consideradas de alto desempenho se elas possuem resistência mecânica, resistência ao fogo, resistência química, resistência à variação brusca de temperatura, entre outras (Smith, 1998). O avanço nas propriedades das fibras foi concretizado completamente no século 20 , com a introdução dos materiais sintéticos tais como o náilon, em 1930, e o poliéster, em 1950 , os quais integram a maior parte dos tecidos técnicos existentes no mercado hoje. Ao mesmo tempo em que o poliéster possui $50 \%$ de aumento na carga de ruptura sobre o algodão, o kevlar apresenta $300 \%$ de aumento na carga de ruptura e $1000 \%$ de aumento na resistência ao alongamento. 
O desenvolvimento de fibras de alto desempenho tem obrigado engenheiros e projetistas a rever a capacidade estrutural de técnicas têxteis tradicionais tais como tecelagem, trançado, tricô e bordado. A qualidade de materiais têxteis é dependente da interação entre as propriedades do material e a geometria estrutural, interagindo nas fibras ou no sentido em que elas são ordenadas. Cada uma das técnicas têxteis representa uma arquitetura muito específica das fibras e como podem ser usadas para criar uma grande variedade de materiais para o projeto.

As fibras naturais (algodão, madeira, seda, entre outras) estão direcionadas à estética para tecidos de vestuário. Até 100 anos atrás, as fibras também foram usadas em aplicações de engenharia, os chamados têxteis industriais ou técnicos. Com a introdução de fibras manufaturadas (raiom, acetato, náilon, poliéster, entre outras) na primeira metade do século 20 , não eram somente novas qualidades de alto desempenho que estavam disponíveis para tecidos da moda, mas também propriedades técnicas superiores. Por exemplo, o reforço utilizado em pneus automotivos à base de cordonéis de algodão em 1900 foi aperfeiçoado de 1935 a 1955 com o uso do raiom e, finalmente, de náilon, poliéster e aço, o qual domina o mercado atualmente (Hearle, 2001).

Um processo de substituição similar de fibras naturais e artificiais para fibras sintéticas ocorreu em muitos tecidos técnicos. A máxima resistência de fibras comerciais de náilon e poliéster é de aproximadamente 10g/denier. A combinação de alta resistência e alongamento moderado fornece alta energia na carga ou trabalho de ruptura. Uma boa recuperação das propriedades significa que elas podem resistir a choques repetitivos de alta energia. Neste aspecto, fibras de náilon e poliéster são incontestáveis como fibras de alto desempenho, embora o aumento da rigidez com o grau de carregamento reduza o desempenho em aplicações balísticas. Como exemplo pode-se citar o poliéster como uma das fibras mais selecionadas para cordas de alto desempenho com típica carga de ruptura em torno de 15 toneladas, usadas para ancorar plataformas petrolíferas com profundidade de 1000 a 2000 metros (Hearle, 2001). 
Fibras de alto desempenho, tais como superfibras, fibra de alta função como sensor e atuador, e fibras de alto contato, que possuem uma nova sensibilidade, como, por exemplo, as fibras ultrafinas, são exemplos de fibras de alta tecnologia. Fibras de alto desempenho, as quais têm propriedades físicas melhoradas quando comparadas às fibras convencionais, necessitam ser distinguidas das superfibras. Superfibras têm sido produzidas por intensa pesquisa e desenvolvimento para alcançar a resistência final de materiais fibrosos, e são em especial aplicadas para usos industriais. Estas fibras possuem tenacidade superior a 20 g/denier e o desempenho mecânico na segunda geração de superfibras propicia a tenacidade acima de $40 \mathrm{~g} /$ denier. No Japão todas as superfibras são produzidas comercialmente por fiação gel (gel-spinning) e fiação liquida cristalina e são utilizadas em várias áreas industriais, incluindo engenharia civil, automobilísticas, artigos para esporte, automação, peças para máquinas e mecanismos e indústrias aeronáutica e espacial (Hongu et al., 2005).

Fibras de aramidas, tais como kevlar (DuPont) e twaron (Teijin), são famosas por sua utilização em coletes à prova de balas e outras formas de proteção balística, bem como para resistência ao corte e retardação do fogo. Desenvolvidas em 1960, as aramidas são resistentes devido às suas longas cadeias moleculares, as quais são completamente direcionadas e altamente compactadas, resultando em fibras de tenacidade alta e módulo de elasticidade alto. Na Figura 22 é mostrada a estrutura molecular do kevlar.

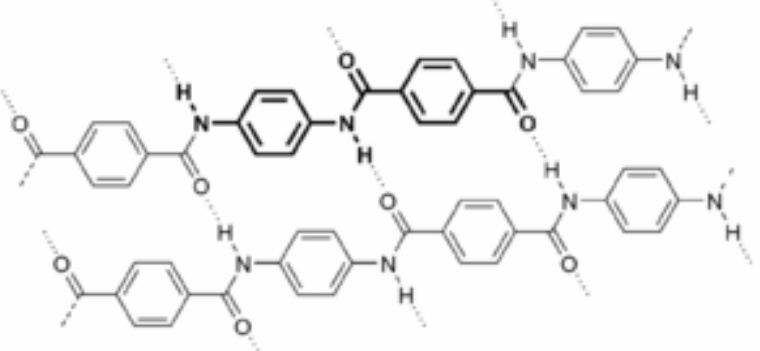

FIGURA 22. Estrutura molecular do kevlar

As fibras de polietileno de ultra-alto peso molecular (PEUAPM) ou ultra high molecular weight poly-ethylene (UHMWPE), são conhecidas pelos nomes comerciais dyneema (Toyobo/DSM) e spectra (Honeywell), e fabricadas a partir do polietileno de ultra-alto peso molecular pelo processo especial chamado fiação gel, comentado anteriormente. 
O PEUAPM é a menos densa de todas as fibras de alto desempenho e mais resistente à abrasão. É também mais resistente à radiação ultravioleta e a produtos químicos do que as fibras de aramidas. Este material é fabricado para amarrações e linhas de pesca, as quais são leves, flutuam e resistem à luz solar, luvas resistentes ao corte e trajes de proteção, tais como faces de esgrima e blindagens balísticas leves. Nos compósitos, agrega resistência ao impacto e absorção de energia para produtos reforçados com vidro e carbono.

$\mathrm{Na}$ área naval, o PEUAPM quase não conduz eletricidade, tornando-se transparente para o radar, entretanto, não resiste à esterilização por raios gama e tem relativamente ponto de fusão baixo, da ordem de $150^{\circ} \mathrm{C}\left(302^{\circ} \mathrm{F}\right)$, duas características que impedem a sua utilização em que se requer resistência à temperatura alta.

As fibras híbridas compõem uma mistura de polímeros em tecidos ou fibras estruturais, as quais podem alcançar propriedades adequadas ao uso final. Trajes confortáveis antiestáticos e retardantes de fogo podem ser confeccionados especialmente com fibras de aramida, porém existe a necessidade da inserção regular de filamentos de carbono para dissipar o carregamento estático. As fibras para aplicações de resistência ao corte mantêm propriedades táteis boas com envoltório de algodão em torno de polietileno de alto peso molecular e coberto com fibra de vidro. Uma fibra simples pode ser extrudada de dois ou mais tipos de polímeros em várias configurações para exibir as propriedades de ambos os materiais. Na figura 23 é mostrado um exemplo da concepção de uma fibra híbrida.

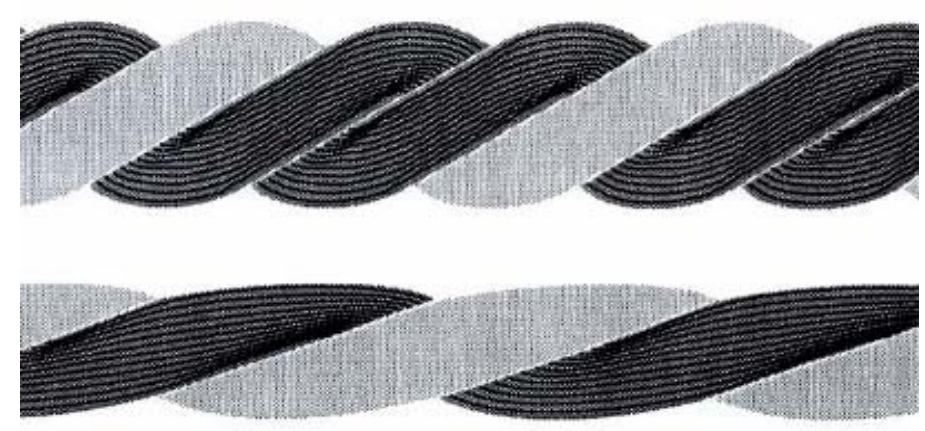

FIGURA 23. Concepção de fibras híbridas 
Estruturas especiais tais como cordas são fabricadas de fibras têxteis e são definidas como corpos têxteis cilíndricos cujas secções transversais são pequenas, se comparadas ao comprimento, e são usadas como membros de tração. A estrutura da corda contém grande número de fibras sintéticas ou naturais controladas, com configurações flexíveis, usualmente para propiciar alta resistência à ruptura com a mínima quantidade de fibras. A estrutura da corda começa com os filamentos ou fibras têxteis. Seu tipo e tamanho definem o ponto de partida de cada estrutura da corda. Estes materiais podem ser produzidos pela indústria química, empresas especializadas na produção de fibras têxteis ou, sobretudo para filamentos ou divisão de películas de polipropileno, o próprio fabricante da corda.

As dimensões das fibras são muito pequenas, da ordem de um milímetro ou menos, e podem conter várias centenas de pequenos filamentos de 10 a $50 \mu \mathrm{m}$ de diâmetro. Os tipos de materiais normalmente utilizados são náilon, poliéster, vidro, aramida, PEUAPM, entre outros. O polipropileno é usado em forma de filamentos na corda, porém, em uma quantidade menor. A geometria é mais complicada devido aos múltiplos níveis de torção ou formas trançadas, porém, programas de computação podem ser usados para avaliar a sua geometria e computar as quantidades necessárias para fabricação (Mckenna et al., 2004).

Sistemas de amarração, que muitas vezes são compostos de correntes de aço nas extremidades e cordas de fibras sintéticas no centro, são cada vez mais encontrados em aplicações como plataformas de exploração de petróleo nos mais profundos lugares. Os sistemas de amarração com cordas de fibras sintéticas proporcionam numerosas vantagens sobre sistemas de amarração em aço (cordas de arame e correntes de aço), particularmente em aplicações em águas profundas, para as quais o elevado peso do aço é excessivo. É, portanto, essencial o modelamento do comportamento mecânico de longos sistemas de amarração, a fim de reduzir as necessidades de testes de alto custo para diferentes parâmetros e condições de operação (Beltran; Williamson, 2004).

O modelo contínuo elástico não linear tem sido desenvolvido para analisar a rigidez axial global de estruturas fibrosas com um grande número de componentes torcidos (Groreishi et al., 2007). Na Figura 24 é mostrada a construção básica estrutural de uma corda. 


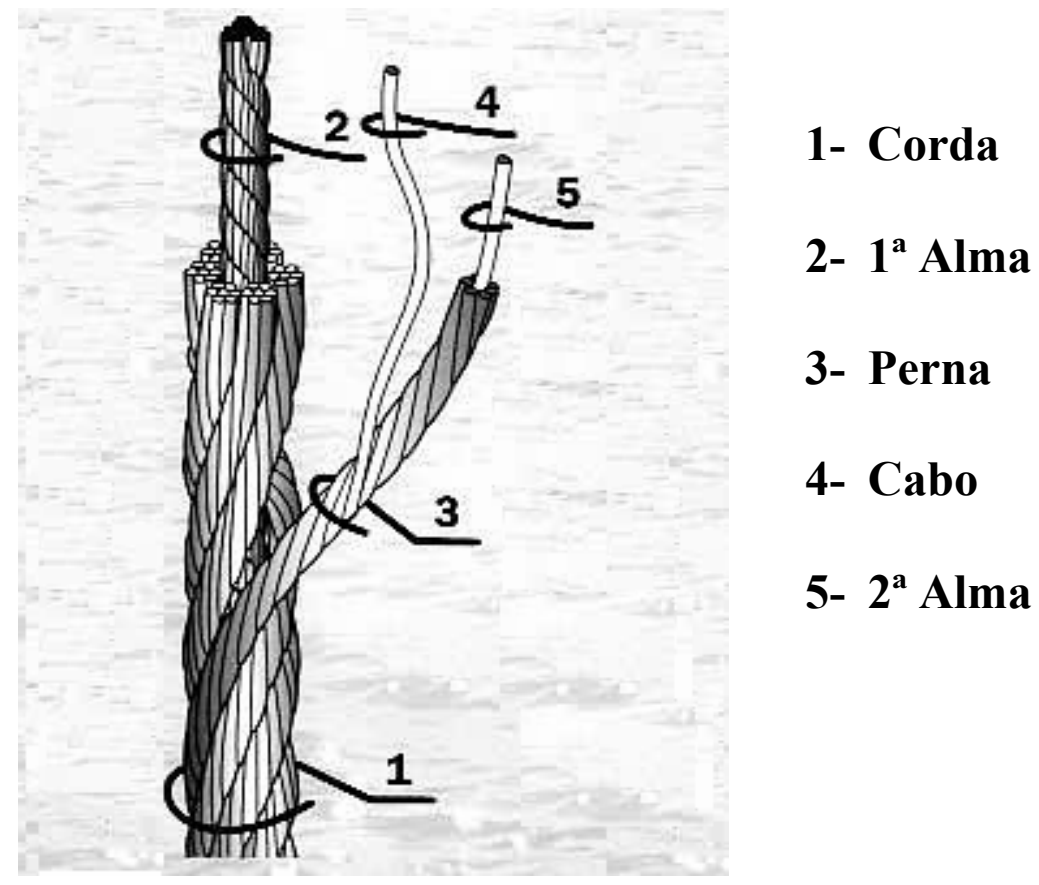

FIGURA 24. Construção básica da corda

Grandes cordas de fibras sintéticas são formadas com milhões de fibras e caracterizadas pela complexa arquitetura e uma estrutura principal na qual a base de componentes têxteis é modificada pelas operações de torção. Esta estrutura é então a componente base para a próxima maior estrutura. Sua estrutura principal conduz para a aproximação ideal quando a estrutura superior é a corda de fibra e as estruturas inferiores são a componente base, com diversos tipos diferentes de elementos entre o componente base e a corda de fibra.

\subsubsection{Propriedades básicas das fibras}

As propriedades do polímero necessárias para formação da fibra são:

- Massa molar - O polímero deve ter massa molar alta, que consequentemente resulta em fibras mais longas;

- Linearidade - Somente polímeros predominantemente lineares formarão suficientes regiões cristalinas, permitindo um número adequado de forças intercadeias de atração que ocorrem dentro do sistema polimérico;

- Forças de atração interfibras - Deve haver suficiente grau de união intermolecular ou um ou mais tipos de ligações tais como pontes de hidrogênio, forças de Van der Waals, bandas covalentes ou ligações cruzadas e bandas iônicas; 
- Orientação - A fibra consiste de um grande número de cadeias poliméricas individuais arranjadas, seja em formas altamente ordenadas e orientadas, chamada região cristalina, ou randômica, chamada região amorfa;

- Ponto de fusão - Quando o polímero é altamente cristalino ou a atração intermolecular entre as moléculas poliméricas é forte, a resistência ao calor é alta.

As fibras dispõem de uma ampla variação química, elétrica, mecânica, ótica e outras propriedades, e as propriedades do produto fibroso, naturalmente, dependem das propriedades das fibras das quais é formado.

\subsubsection{Resistência mecânica das fibras}

A tensão de ruptura da fibra é uma de muitas características físicas importantes de reforços fibrosos. Medidas de ruptura são usadas para desenvolvimento da fibra em compósitos e na sua manufatura como um meio de predizer as propriedades e para avaliar a consistência de lotes de fibras utilizadas. Dois métodos são usados para medir a ruptura da fibra, o teste do filamento simples ou feixe seco (dry bundle) ou o ensaio de tração (tow testing). O teste de filamento simples é o caminho mais direto para determinar a resistência da fibra e assim fornecer os melhores dados para entendimento dos fundamentos de comportamento e variabilidade. Um lado negativo é que esta técnica é um pouco difícil, devido ao manuseio de pequenos diâmetros, fibras de alto módulo e medições de pequena carga e filamentos de diâmetros pequenos que requerem cuidado especial para evitar erros que possam comprometer a precisão do teste. $O$ teste de tração é atrativo, na medida em que permite a avaliação de centenas ou milhares de filamentos.

A variabilidade de resistência dentro de uma amostra é muito importante. Modelos indicam que a resistência de compósitos não é determinada somente por meio da tensão de ruptura do reforço fibroso, mas também pela distribuição da resistência da fibra. Isto ocorre a partir da falha de algumas fibras fracas dentro dos compósitos em cargas baixas que podem conduzir à falha do compósito como um todo. 
A estatística de Weibull é geralmente usada para prognosticar a força testada em diferentes volumes (espessura, comprimento, área), para prever a resistência do feixe de fibras e finalmente estimar a ruptura dos compósitos reforçados com fibras.

O diâmetro médio é usado para calcular a tensão de ruptura da fibra individual. O uso do diâmetro médio é suficiente para determinação da resistência média da fibra, porém, o uso do diâmetro médio em vez de cada diâmetro individual da fibra significa que os valores da resistência individual da fibra não serão estritamente exatos (Mortensen, 2007).

\subsubsection{Outras propriedades das fibras}

A escolha das fibras para serem usadas como matéria-prima em uma aplicação específica depende de uma única combinação de diferentes propriedades.

\subsubsection{Módulo inicial}

O módulo inicial é uma medida de resistência à deformação da fibra. Quando o módulo é elevado, a fibra terá um alongamento inicial baixo, e vice-versa. Quando uma fibra ondulada é sujeita a tensão axial, uma carga extremamente pequena é registrada até que toda a ondulação presente na fibra seja removida.

\subsubsection{Energia na ruptura}

A energia requerida para romper a fibra é conhecida como energia à ruptura ou trabalho de ruptura, sendo também chamada de tenacidade. Pode ser calculada pela área estimada sob a curva tensão-deformação da fibra. Entretanto, a variabilidade do comprimento, a densidade linear e a ruptura da fibra individual tornam difícil comparar o trabalho de ruptura de diferentes materiais. 


\subsubsection{Elasticidade}

A elasticidade é uma medida da propriedade da fibra pela qual tende a recuperar seu comprimento original após deformação, quando a tensão axial aplicada é completamente removida. O estudo da elasticidade da fibra e da recuperação sob tensão aplicada tem grande importância técnica, devido ao conhecimento da extensão na qual a fibra é deformada permanentemente, sendo essencial para o processamento subsequente e para alcançar as propriedades desejadas de tecidos destinados a aplicações especiais.

\subsubsection{Técnicas de medição das forças multidirecionais nas fibras}

Técnicas de medição das forças multidirecionais nas fibras tem sido muito utilizadas e os resultados levam a estudos que estimam a isotropia das propriedades mecânicas destes materiais. Este método provou ser eficaz para a análise das tensões com a utilização de sensores (strain gauge) para monitoramento da tensão individual por fibra. Na Figura 25 tem-se uma amostra de tecido que utiliza este método para identificar a distribuição das forças multidirecionais (Wasiak et al., 2004).

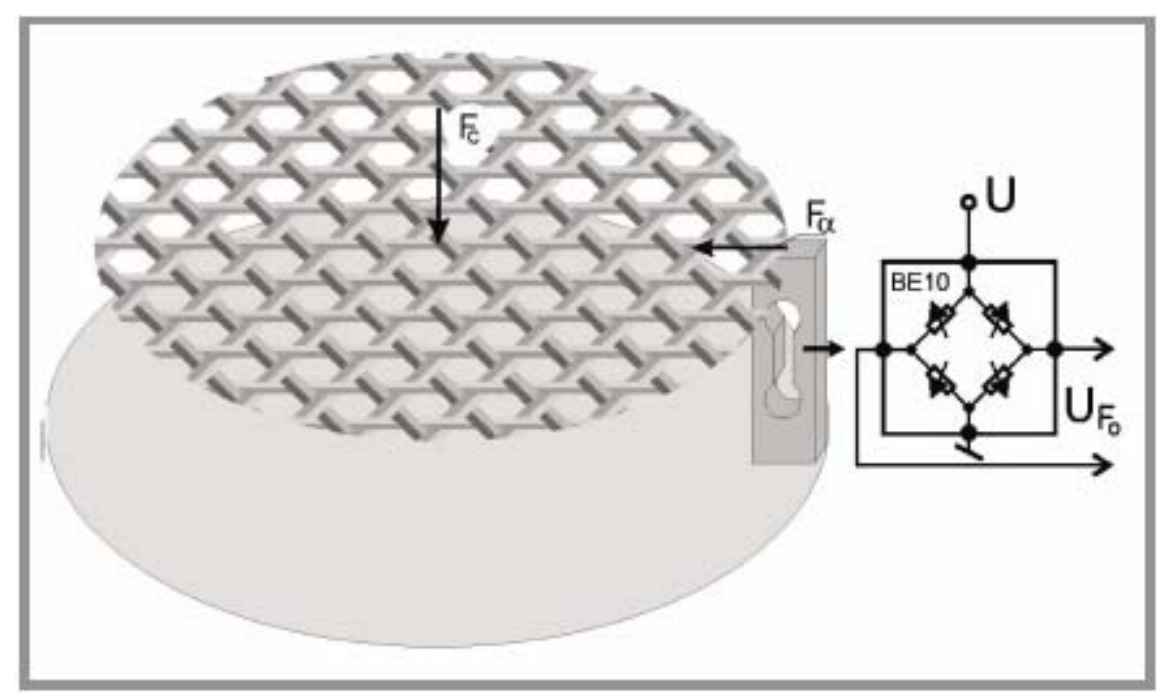

FIGURA 25. Esquema de medição das forças multidirecionais

O desenvolvimento de estruturas de produtos têxteis tem tido crescimento intenso, e a faixa de aplicações tem evoluído consideravelmente levando ao aumento da utilização de métodos de medição de forças. 


\subsection{Fibras têxteis}

As fibras têxteis são produzidas valendo-se de feixes de filamentos contínuos para manufatura de fibras e tecidos de alto desempenho. Elas têm reunido requerimentos funcionais específicos para utilização final, os quais podem ser alcançados pelas técnicas especiais de produção e preparação da fibra, seleção de fibras especiais ou pela combinação de ambas.

Normalmente o feixe inicial, chamado de fibra singela, é adquirido com os filamentos contínuos e submetido aos processos de estiramento e torção para aumentar suas propriedades mecânicas, em especial a resistência à ruptura. 0 sentido de torção da fibra dependerá da sua aplicação final, podendo ser feita nos sentidos horário e anti-horário ou em ambos.

A fibra torcida no sentido horário é considerada como torção " $Z$ " e a fibra torcida no sentido anti-horário como torção "S", conforme configuração mostrada na Figura 26.

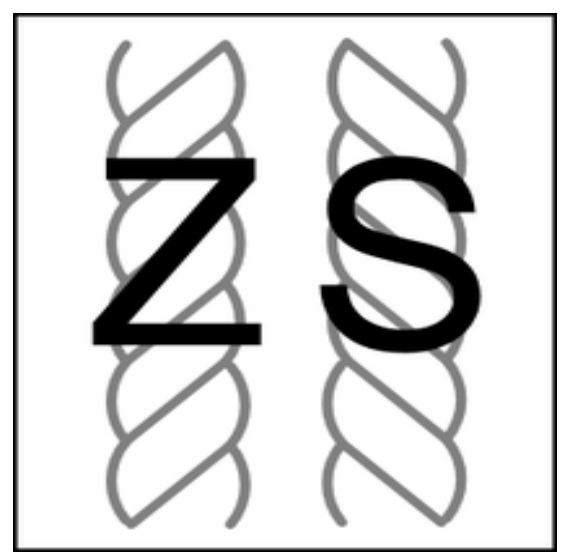

FIGURA 26. Sentido de torção da fibra têxtil

Como exemplo pode-se citar as fibras têxteis para aplicação em correias de transmissão de potência, os quais são projetadas com ambas as torções intercaladas com a finalidade de equilíbrio dinâmico.

\subsubsection{Acabamento nas fibras têxteis}

Nas fibras têxteis, como os filamentos do feixe solidificam-se e deslocamse a velocidade alta, a superfície de fricção atravessa o ar gerando eletricidade estática, fazendo o feixe de filamentos menos coeso. 
Para facilitar os processos de delineação e movimentação dos filamentos, emulsão final com agente antiestático, óleos lubrificantes, bactericidas, agentes autolimpantes, entre outros, são usados para umedecer o feixe, mediante um rolo imerso em solução ou por meio de um dispositivo específico. Como exemplo, muitos destes elementos utilizados para acabamento na fiação do náilon 6 e do náilon 6.6 são à base de água. O acabamento à base de água aplicado na fibra pode agir como um plastificante para reduzir a temperatura de transição vítrea e mudar a taxa de polimerização no processamento final.

\subsubsection{Estiramento nas fibras têxteis}

Para desenvolver a resistência das fibras têxteis, moléculas do polímero em ambas as regiões, amorfa e cristalina, estão mais orientadas por alongamento das fibras entre dois rolos com diferentes velocidades. A relação dos dois rolos é chamada de taxa de estiramento. Na Figura 27 é mostrada a estrutura molecular típica do tipo amorfa e cristalina em polímeros.

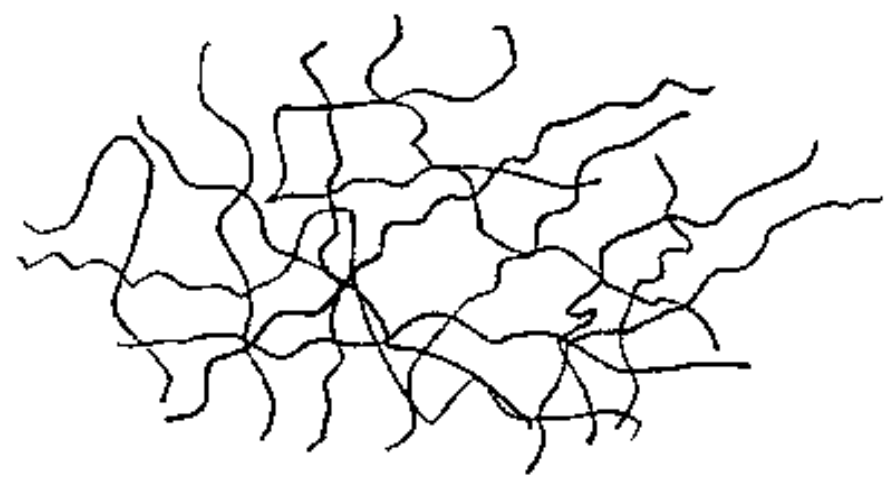

Polimero de estrutura amorfa

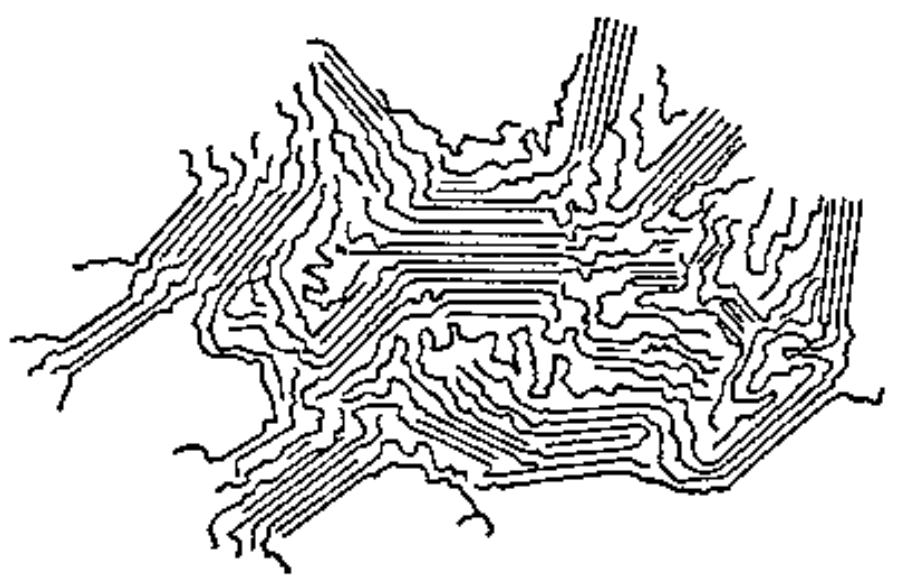

Polimero de estrutura cristalina

Fonte: Canevarolo, 2002

Figura 27. Estrutura molecular amorfa e cristalina em polímeros 
Taxa de estiramento alta conduz a orientação molecular alta e, deste modo, resistência da fibra têxtil alta.

\subsubsection{Processos de integração nas fibras têxteis}

Para aumentar a eficiência do processo e reduzir os custos de produção, um esforço industrial conseguiu integrar os processos de fiação e estiramento no processamento das fibras têxteis. Portanto, existem agora três diferentes tipos de modalidades do processo de fiação. Cada um destes três processos fornece um conjunto diferente de propriedades e morfologia (Lewin, 2006).

- Processo de fiação e estiramento separados em duas etapas;

- Processo de estiramento em camadas com um estágio (stack-draw);

- Processo de estiramento por rotação com um estágio (spin-draw).

Nas Figuras 28 e 29 são mostrados, de forma esquemáticos, os processos de fiação do náilon e do poliéster. 
1- Petróleo

2- Aromáticos

3- Produçăo do Náilon6.6

4 - Produçăo do Náilon 6

5- Ácido Adipico

6- Sal de Hexametileno Diamina

7- Caprolactama

8- Produçăo do Náilon 6 ouNáilon 6.6

9- Fusăo

10 - Fibras de Filamentos de Náilon (1 Estágio)

11 - Fibras de Filamentos de Náilon (Multi-Estágio)

12 - Produçăo de Fibras de Náilon

13- Fiaçăo

14- Estiragem

15- Fibras de Filamentos Lisos

16- Bobina de Fiaçăo

17-Acumulador de Fibras

18- Estiragem

19- Frisagem

20- Fibras Contínuas

21- Fibras Cortadas

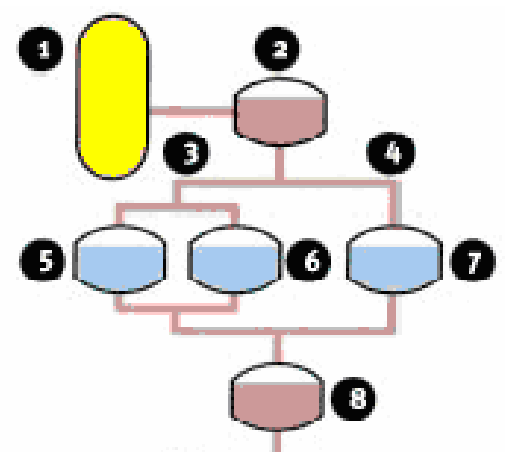

9
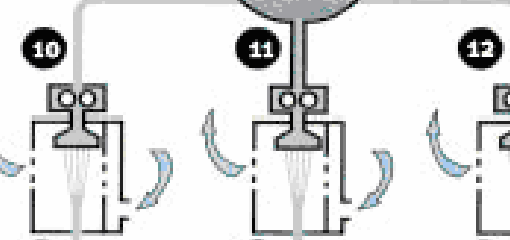

13

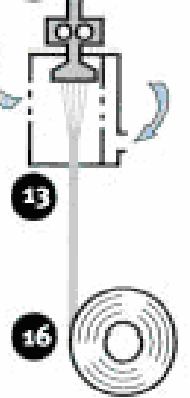

이이

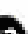

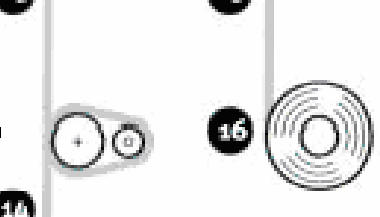

13

14

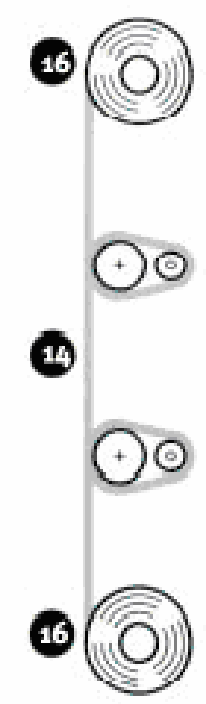

17
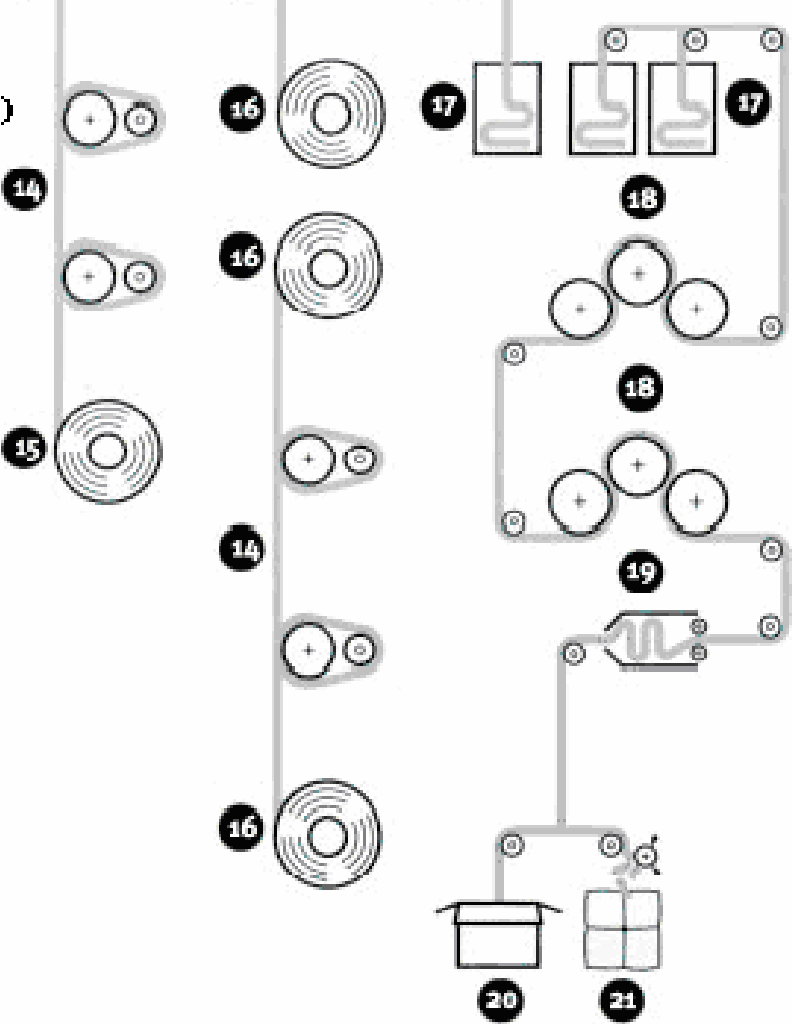

FIGURA 28. Processo de fiação do náilon 
1- Petróleo

2- Ácido Teraftálico

3- Etilenoglicol

4- Polietileno Tereftalato

5- Fusăo

6- Fibras de Filamentos de Poliéster (1 Estágio)

7- Fibras de Filamentos de Poliéster (Multi-Estágio)

8- Produçăo de Fibras de Poliéster

9- Fiaçăo

10 - Estiragem

11- Fibras de Filamentos Lisos

12- Bobina de Fiaçăo

13- Acumulador de Fibras

14- Estiragem

15- Frisagem

16- Fibras Contínuas

17- Fibras Cortadas

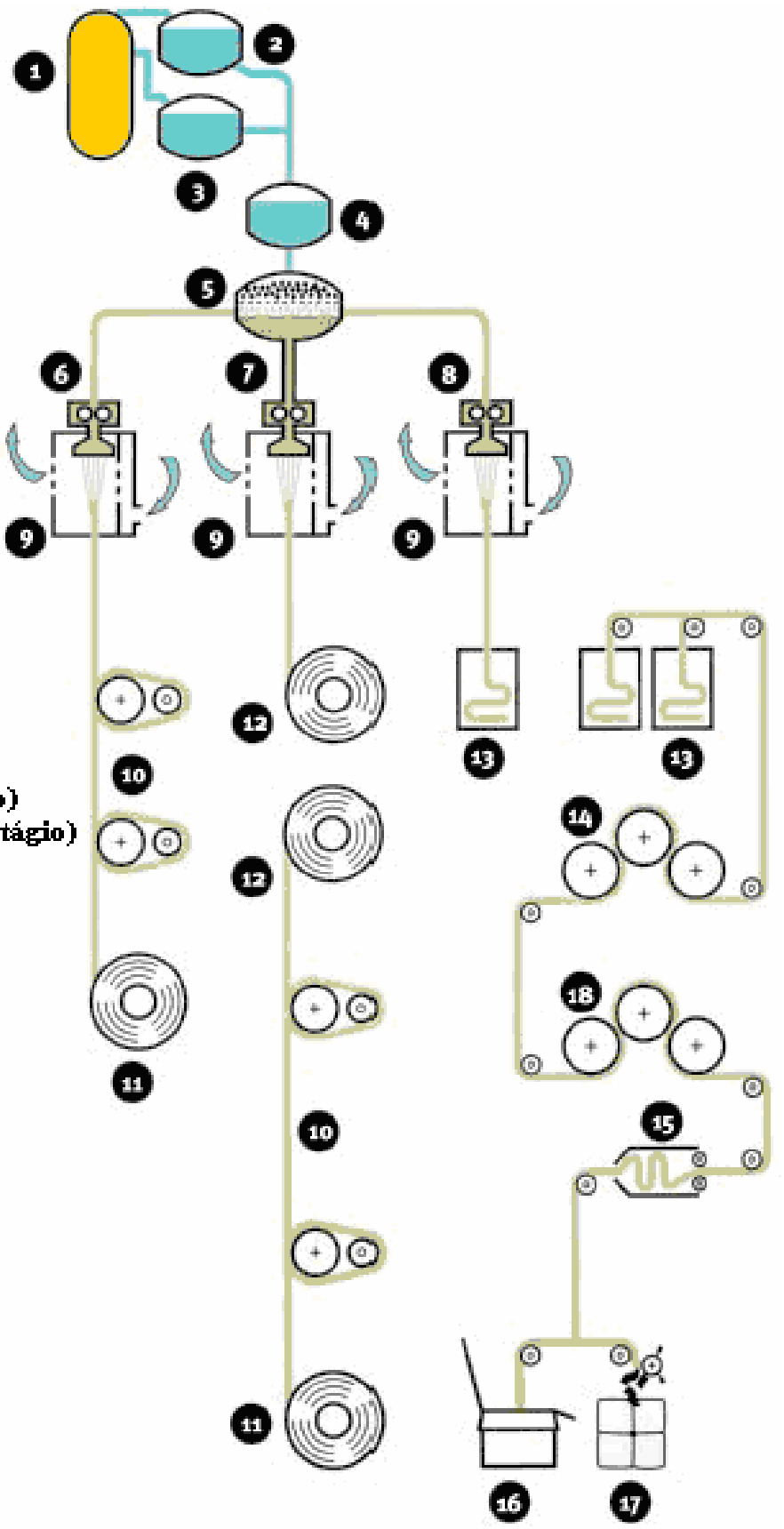

FIGURA 29. Processo de fiação do poliéster

Filamentos produzidos em operações de velocidade alta que não combinam processos de estiramento e fiação devem ser submetidos ao subsequente processo de estiramento e torção para aumentar as propriedades (Lewin, 2006). 


\subsubsection{Fibras de náilon}

Segundo a Federal Trade Comission (FTC), o náilon é formado por uma cadeia longa de poliamida sintética, no qual em que até $85 \%$ do grupo amida está ligado diretamente a dois anéis aromáticos. A ligação amida $-\mathrm{NH}-\mathrm{CO}$ - define esta classe. O náilon é considerado um polímero de engenharia, mas também é muito utilizado na forma de fibras.

A resistência mecânica alta que esses materiais possuem deve-se às ligações do tipo ponte de hidrogênio, formadas entre as carbonilas de uma cadeia e o hidrogênio da ligação amida da outra cadeia. Por outro lado, a presença desta ligação facilita a permeação de moléculas de água, difundindo-se entre as cadeias e se posicionando na ponte de hidrogênio. Esta capacidade de absorção de água torna as poliamidas hidrofílicas. Em função do número variável de pontes de hidrogênio por grupos $\mathrm{CH}_{2}$ têm-se diferentes níveis nominais de absorção de água (Canevarolo, 2002).

Náilon 6 e náilon 6.6 são as principais poliamidas para produção comercial de fibras e resinas. Os monômeros intermediários correspondentes são a caprolactama, o sal de hexametileno diamina e o ácido adípico (HA-salt). A importância comercial destas duas poliamidas tem estimulado consideráveis desenvolvimentos e otimização de processos comerciais para seus monômeros (Lewin, 2006). Na figura 30 são mostradas as estruturas moleculares do náilon 6.6 e do náilon 6.

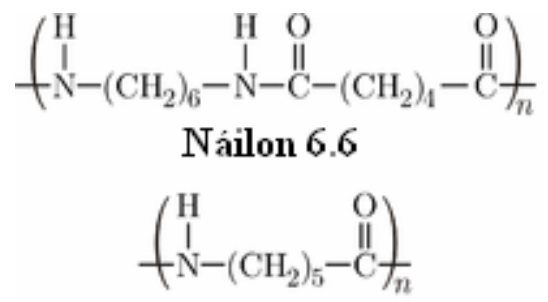

Náilon 6

FIGURA 30. Estrutura molecular do náilon 6.6 e náilon 6

Fibras de poliamida são superiores às fibras naturais e artificiais com respeito às propriedades de tenacidade e alongamento, resistência à abrasão, resistência à degradação, entre outras. Com massa molar alta, as poliamidas lineares, que são usadas para fibras sintéticas, contêm em particular grupos metileno entre os grupos carbonamida. 
Eles abrangem aquelas composições que podem ser fundidas e fiadas em forma de filamentos sem decomposição (Hearle, 2008).

Fibras de poliamida são basicamente convertidas com base em polímeros de poliamida pelo processo já mencionado denominado fiação por fusão. Este processo é acompanhado pelo projeto da fibra, entrelaçamento e empacotamento. Em muitos casos, o processo é projetado e integrado com a fiação para propiciar o processamento da fibra em apenas um estágio (Lewin, 2006).

Ensaios de espectroscopia e ensaios mecânicos no náilon 6.6 mostraram que, com demonstração de testes simples de tração, as fibras podem se comportar diferentemente, em condições de fadiga, apresentando mudanças significantes na estrutura das fases amorfas (Ramirez et al., 2004).

Segundo Marcellan et al. (2003), o comportamento mecânico da fibra de náilon 6.6 mostra dependência da taxa de deformação devido ao comportamento viscoelástico das regiões amorfas.

Ensaios de desenvolvimento estrutural da fibra de náilon 6.6 por análise de difração de raios $X$ tornaram possível observar a deformação em diferentes temperaturas das frações quantitativas do cristal e das fases mesomórficas e amorfas (Ran et al., 2000). Na Figura 31 é mostrada uma estrutura típica de fibras de náilon em corte transversal e vista longitudinal.
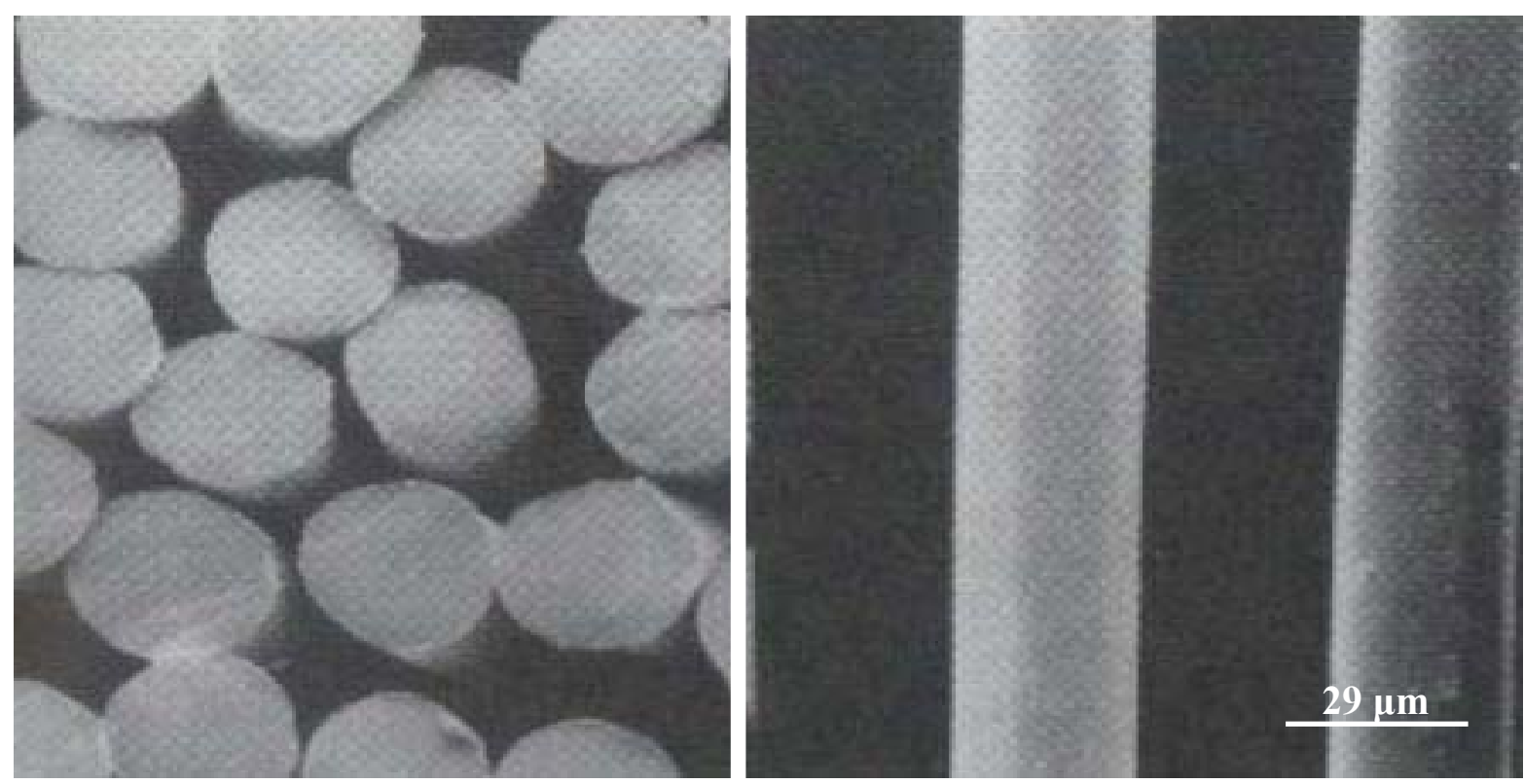

Fonte: Collier e Tortora, 2001.

FIGURA 31. Estrutura típica das fibras de náilon 
Quadro-resumo de algumas características típicas do náilon:

- Família de resinas de engenharia;

- Tenacidade excepcional e resistência ao desgaste;

- Coeficiente de atrito baixo;

- Propriedades eletrônicas e resistência química excelentes;

- Hidrofílicas;

- Estabilidade dimensional menor;

- Estado de equilíbrio com teores de $2,5 \%$ de umidade e $50 \%$ de umidade relativa do ar;

- Em geral as dimensões aumentam $0,2 \%$ a $0,3 \%$ para cada $1 \%$ de umidade absorvida;

- A estrutura cristalina tem influência na rigidez, resistência à tração e ao calor;

- Cristalização baixa, grande tenacidade, poder de alongamento, resistência ao impacto e redução tanto da resistência à tração como da rigidez.

Polímeros de náilon podem ser formados de muitas maneiras. Os quatro métodos mais importantes para polímeros industriais são:

1. A condensação de diaminas com diácidos;

2. A pura condensação de aminoácidos;

3. A polimerização hidrolitica de lactama (lactona + amida, amida cíclica), que envolvem hidrólises parciais do lactam para um aminoácido;

4. A adição do anidro na polimerização dos lactams.

Os métodos 1 e 3 são os mais importantes na manufatura das fibras; o método 2 é usado para determinados náilons específicos e o método 4 não é usado para manufatura das fibras, e sim para auxiliar na reação durante a moldagem (Richards, 2004).

\subsubsection{Propriedades de umidade do náilon}

Muitas vezes pensava-se que o náilon era considerado uma fibra hidrofóbica. Entretanto, na prática, a fibra é significativamente hidrofilica e pode absorver um pouco de água dentro da estrutura. A água é capaz de penetrar nas regiões amorfas e bandas de hidrogênio dos grupos amida. 
A água é um bom plastificante para o náilon e isto aumenta a mobilidade das cadeias moleculares, reduzindo a tenacidade, o módulo e a $\mathrm{Tg}$, ao passo que aumenta o alongamento à ruptura. O efeito da água não é tão grande como nas fibras celulósicas tais como a viscose, porém, é suficiente para que os efeitos tenham uma influência significativa nos testes de tração. Em adição, como as fibras absorvem água, ocorre uma mudança nas dimensões em ambas as direções, transversal e axial. Isto pode alterar o tamanho, a forma e a rigidez dos tecidos (Richards, 2004).

\subsubsection{Propriedades de encolhimento do náilon}

Muitas fibras demonstram uma contração irreversível ao calor. Fibras de náilon quando aquecidas a $100{ }^{\circ} \mathrm{C}$ apresentam um encolhimento por volta de $5 \%$. Pela característica hidrofílica da fibra, o encolhimento das fibras úmidas é consideravelmente maior sendo em água aquecida por volta de $10 \%$.

Existe uma série de mecanismos que dão origem a este encolhimento. Quando a fibra é processada, alguns dos polímeros permanecem orientados, mas não estão na forma cristalina. Em condições de aquecimento, isso pode reverter para um estado de menor orientação. Como as regiões cristalinas são aquecidas, sua microestrutura é alterada termicamente e tornam-se mais curtas. Tratamento térmico prévio tem um efeito significativo no encolhimento. Se o náilon 6.6 é aquecido a $200{ }^{\circ} \mathrm{C}$ sem nenhuma tensão, não se encontra encolhimento posterior quando este é aquecido em água (Richards, 2004).

\subsubsection{Temperatura de transição vítrea $\left(\mathrm{T}_{\mathrm{g}}\right)$}

A temperatura de transição vítrea é o valor médio da faixa de temperatura que durante o aquecimento de um material polimérico, de uma temperatura muito baixa para valores mais altos, permite que as cadeias poliméricas da fase amorfa adquiram mobilidade, ou seja, a possibilidade de mudança de conformação. Abaixo da $T_{g}$, o polímero esta no estado vítreo caracterizado por se apresentar duro, rígido e quebradiço (Canevarolo, 2002). Para exemplificar esta mudança na $T_{g}$, pode-se citar um fenômeno conhecido como deformação plana que ocorre em pneus de borracha com reforço de fibras de náilon. Ao passo que o veículo está em movimento, o pneu aquece acima da temperatura de transição vítrea $T_{g}$, mas quando o veículo está parado, o pneu esfria abaixo da $\mathrm{T}_{\mathrm{g}}$. 
O pneu adquire uma marca de deformação plana quando está em contato com o solo. Quando o veículo inicia o movimento novamente, ocorre um funcionamento irregular nesta região até que a temperatura do pneu fique novamente acima da $T_{g}$, provocando desgaste irregular. Esta dificuldade é frequentemente superada pelo uso de diversas camadas de reforços, nas quais somente algumas são de náilon (Richards, 2004).

\subsubsection{Fibras de poliéster}

As normas ISO 2076 e a diretiva EU (European Union) definem o nome genérico do poliéster como "fibra composta de macromoléculas lineares cuja cadeia contém um mínimo de $85 \%$ em massa de um éster de um glicol e do ácido tereftálico" (Guillén, 2003). Poliésteres são polímeros de condensação caracterizados pela presença de grupos ésteres distribuídos igualmente (homopoliésteres) ou aleatoriamente (copoliésteres) ao longo da cadeia molecular. Poliésteres também foram a primeira linha de polímeros de massa molar alta preparados e controlados por etapa de crescimento na reação de polimerização no pioneiro trabalho de Carothers ao final de 1920 (Arroyo, 1997).

Nesta classe a ligação característica é a ligação éster -CO-O-, podendo gerar cadeias saturadas (formando plásticos de engenharia) ou insaturadas (gerando termofixos), dependendo do tipo de material inicial empregado (saturado ou não). Na segunda classe, a dos insaturados, tem-se aqueles normalmente empregados em plástico reforçado com fibra de vidro (PRFV), utilizado para a confecção de cascos de barco, pranchas de surf, estrutura externa de automóveis e caminhões, entre outros (Canevarolo, 2002).

Também denominado de polietileno tereftalato e abreviado como PET conforme a IUPAC (International Union Pure and Applied Chemistry), o polímero poliéster é utilizado em fibras químicas que tendem a apresentar grande poder de competição, em decorrência de seu custo tecnológico baixo, o que possibilita que se torne cada vez mais utilizada. O grande crescimento na utilização de PET em garrafas descartáveis e a poluição que isto tem gerado ao meio ambiente o tornam atualmente um dos polímeros mais reciclados. 
O aumento dramático do crescimento global de poliésteres durante as últimas duas décadas deveu-se ao desenvolvimento do PET destinado à produção de garrafas de bebidas por tecnologia de moldagem por sopro. Em 1994 o consumo global de PET para produção de garrafas foi estimado em 702.000 toneladas nos Estados Unidos, 490.000 toneladas na Europa e 528.000 toneladas em outras localidades, e o forte crescimento de resinas de poliéster para fibras sintéticas, garrafas e filmes foi de 5 a 6\% ao ano até o ano 2000 (Arroyo, 1997).

As fibras de poliéster são pouco elásticas, a sua recuperação ao alongamento é menor quando comparada com a poliamida. No entanto, a recuperação à deformação por flexão é excelente devido à rigidez intrínseca destas fibras. O poliéster é conhecido em diferentes países com diferentes nomes de marcas. Na Inglaterra é conhecido como terilene da $\mathrm{ICl}$ (Imperial Chemical Industries) e nos Estados Unidos como dacron da DuPont. A fibra é encontrada na forma de filamentos bem como na forma de fibras. Uma série de outros poliésteres tem sido convertidos em fibras, mas eles não foram explorados comercialmente (Sen, 2007). Na Figura 32 é mostrada a estrutura molecular do poliéster.

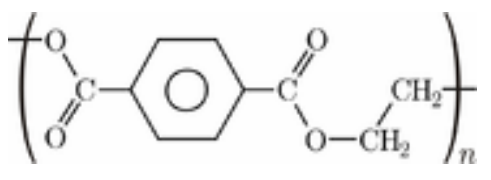

FIGURA 32. Estrutura molecular do poliéster

Como o náilon, tecidos de poliéster também geram eletricidade estática e sofrem encolhimento térmico. Os tecidos demonstram deficiência de adesão quando são revestidos com filmes poliméricos. O maior uso do poliéster e suas blendas com algodão, raiom e lã são em tecidos para roupas, tecidos de uso domésticos e têxteis industriais (Sen, 2007). 


\subsubsection{Síntese do poliéster}

O PET resulta da condensação entre o ácido teraftálico e o etilenoglicol, a uma temperatura de $280^{\circ} \mathrm{C}$, conforme é mostrado na Figura 33.
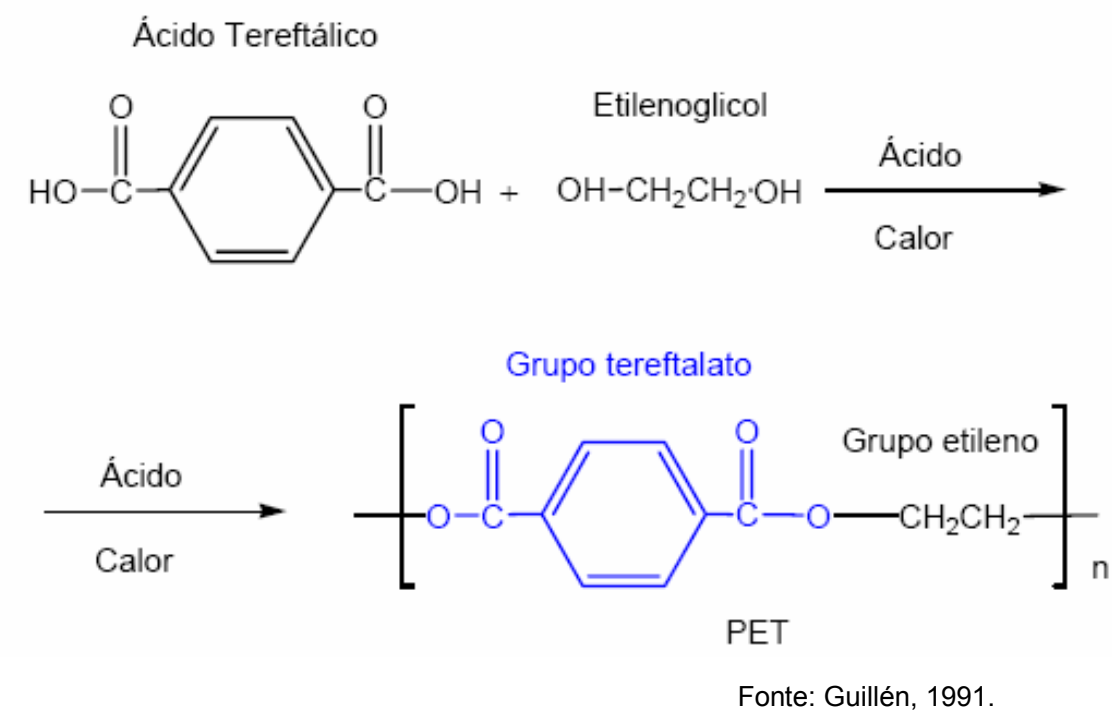

FIGURA 33. Reação de condensação do poliéster

Na Figura 34 é mostrada uma estrutura típica de fibras de poliéster em corte transversal e vista longitudinal. 

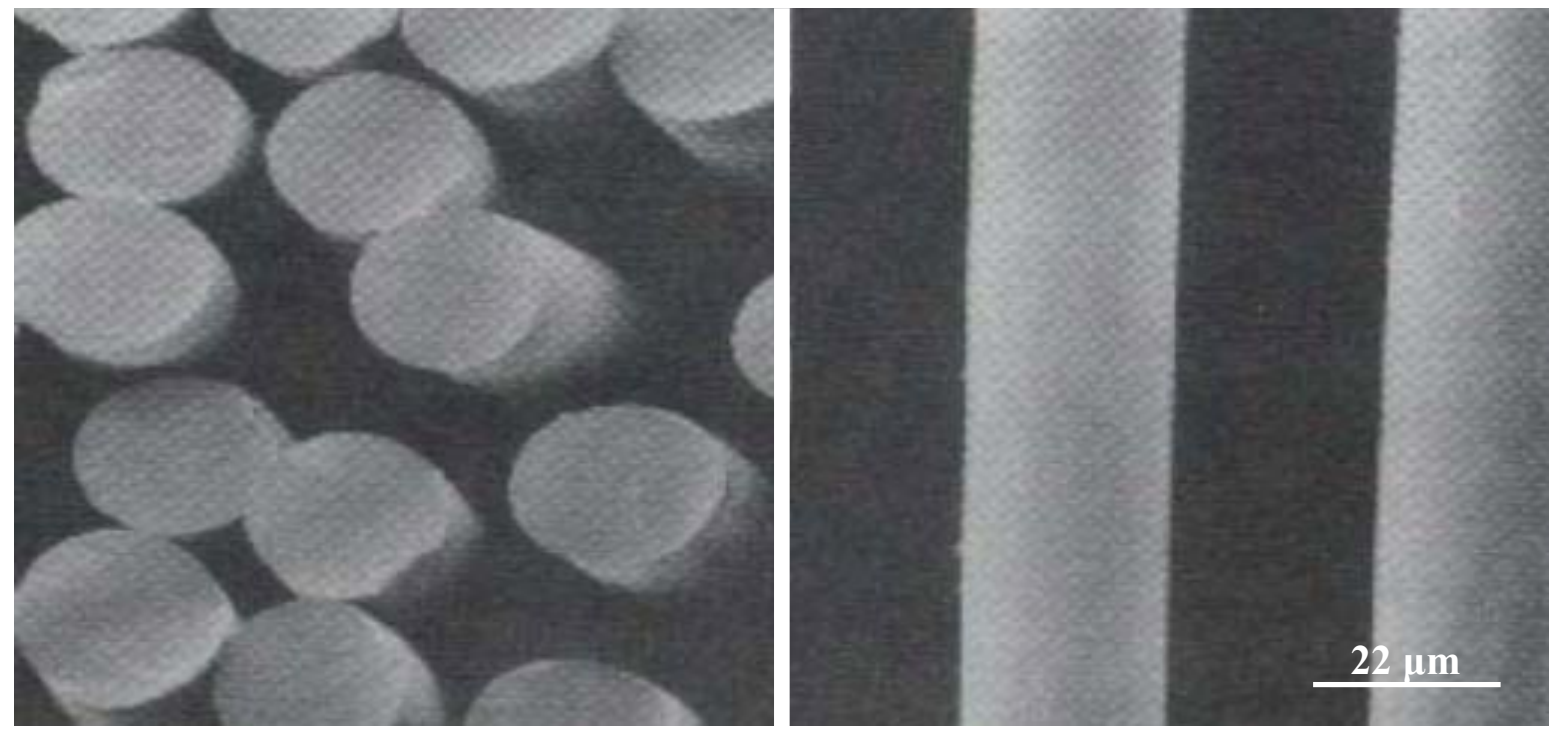

Fonte: Collier e Tortora, 2001.

FIGURA 34. Estrutura típica das fibras de poliéster

Algumas características do Poliéster:

- Resistência mecânica alta;

- Absorção de água baixa;

- Estabilidade dimensional boa;

- Propriedades elétricas excelentes;

- Resistente a temperaturas altas.

\subsubsection{Efeito das modificações químicas e físicas nas fibras de poliéster}

A continuação são descritos os efeitos das propriedades químicas dos poliésteres:

- Efeito dos Alcalinos: As fibras de poliéster têm boa resistência em fraca alcalinidade a temperaturas altas, resistência moderada em forte alcalinidade a temperaturas baixas, e ocorre a degradação em temperaturas elevadas.

- Efeito dos Ácidos: Ácidos fracos, até o ponto de ebulição, não têm efeito nas fibras de poliéster a menos que sejam expostas por períodos longos. As fibras de poliéster têm resistência boa a ácidos fortes em temperaturas baixas. 
- Efeito dos Solventes: Fibras de poliéster são geralmente resistentes aos solventes orgânicos. Produtos químicos usados para limpeza e remoção de manchas não atacam as fibras de poliéster, é certo que misturas de fenol com triclorometano dissolvem as fibras, mas agentes oxidantes e alvejantes não as atacam (Bendak; Marsafi, 1991).

A continuação são descritas as propriedades físicas dos poliésteres:

- Absorção de umidade: Os índices de absorção de umidade do poliéster são baixos, variando entre $0,2 \%$ e $0,8 \%$. Embora os poliésteres sejam impermeáveis, a umidade pode ser conduzida pela superfície da fibra sem ser absorvida por ela.

- Peso específico: O peso específico varia de 1,22 a 1,38 e, dependendo do tipo de fibra de poliéster, torna-se moderado. Fibras de poliéster possuem uma densidade superior às fibras de náilon e inferior às fibras de raiom, enquadrando-se em uma faixa de padrão médio.

\subsubsection{Efeito da radiação nos poliésteres}

Análise por difração de raios $\mathrm{X}$ em amostras de poliéster irradiadas por nêutrons demonstrou haver redução na resistência mecânica devido a microfadiga desenvolvida nos grãos da fibra durante a irradiação (Mallick et al., 2005).

\subsubsection{Efeito da temperatura nos poliésteres}

O ponto de fusão do poliéster é próximo ao do náilon, variando de $250{ }^{\circ} \mathrm{C}$ a $300{ }^{\circ} \mathrm{C}$. Fibras de poliéster encolhem com o calor, fundem-se e deixam um resíduo duro e de cor negra. A combustão do tecido provoca um odor forte e irritante. O controle do calor nas fibras de poliéster não somente estabiliza a forma e o tamanho dessas fibras como também aumenta a resistência ao dobramento das mesmas (Bendak; Marsafi, 1991). 


\subsubsection{Propriedades mecânicas dos poliésteres}

O aumento da resistência das fibras de poliéster é possível dependendo do método de manufatura. Geralmente, existem métodos para elevação da resistência, com rendimento de cristalinidade alto e grande orientação molecular, elevando-se as propriedades de tensão de ruptura, módulo de elasticidade inicial e normalmente reduzindo o alongamento. O aumento da massa molar favorece o aumento da tensão de ruptura, módulo e o alongamento. O encolhimento das fibras também varia com o método de tratamento, ou seja, se o relaxamento da tensão e da deformação ocorrer na fibra orientada, o encolhimento diminui, podendo também ocorrer redução no módulo inicial (Bendak; Marsafi, 1991).

Fibras mantidas com o comprimento fixo e a tensão constante, durante o processamento térmico, são menos afetados com respeito à variação do módulo, e a redução nos valores de encolhimento é obtida moderadamente.

$\mathrm{Na}$ Tabela 2 são apresentadas as principais propriedades dos tipos de fibras mais utilizadas comparadas com as propriedades do aço. 


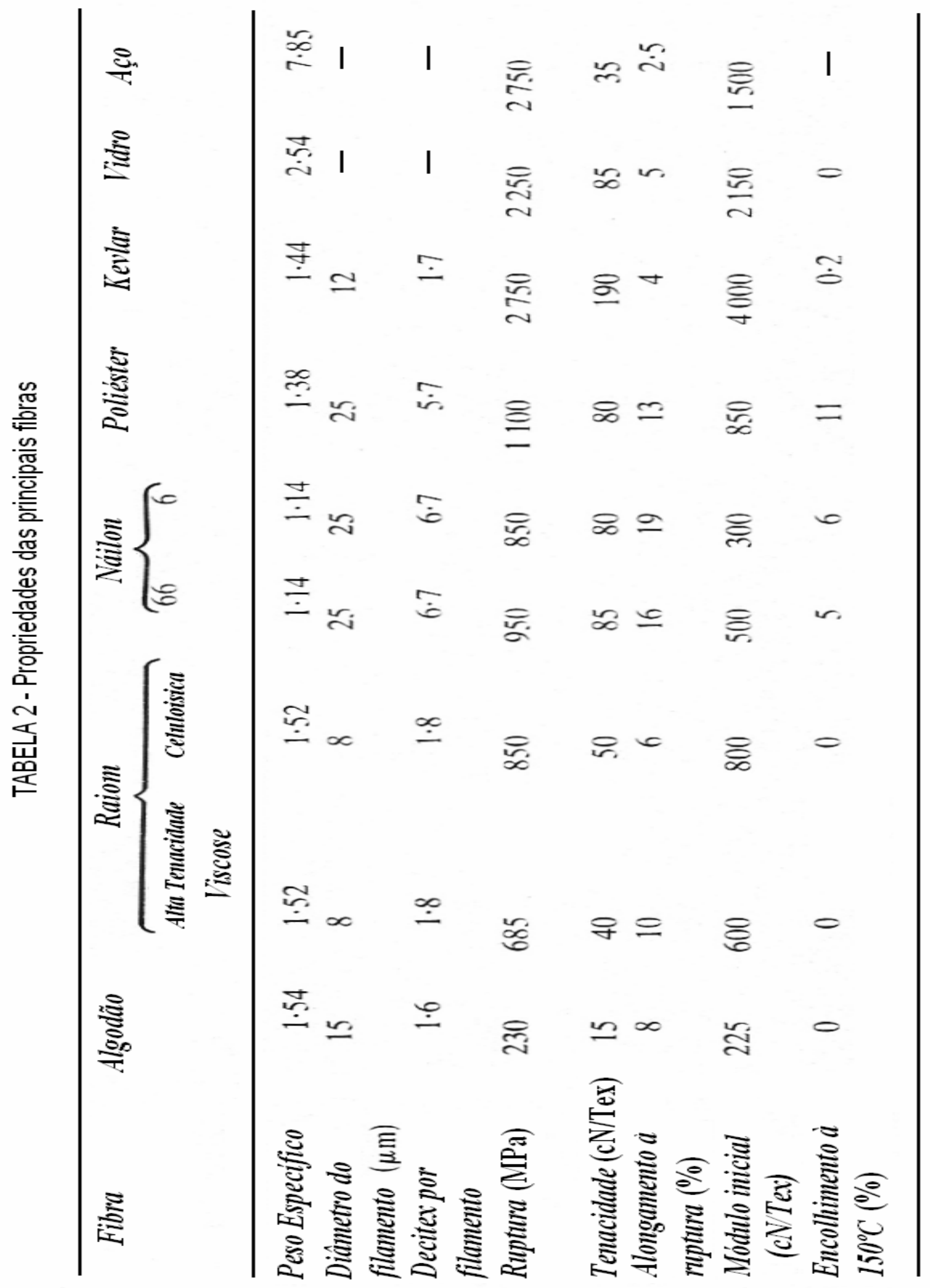


A influência do grau de cristalinidade no valor da força de ruptura e, em consequência, nos valores de tenacidade somente é observada quando as alterações neste grau não causam nenhuma mudança na orientação molecular das cadeias fibrosas do material (Lewandowski et al, 2003).

O carregamento cíclico nas fibras poliméricas pode resultar na ruptura do material por fadiga mecânica. O processamento induz a tensões residuais de compressão na superfície da fibra, conduzindo ao início da trinca na qual normalmente a morfologia da fratura é caracterizada como delaminação axial. Estes tipos de mecanismos de fratura têm sido observados nas fibras de náilon e poliéster (Kerr et al., 2005).

\subsubsection{Outras propriedades dos poliésteres}

Fibras de poliéster exibem resistência à luz solar boa e resistência à abrasão excelente. Sabão e detergentes sintéticos não danificam as fibras. Um dos mais sérios defeitos do poliéster é a qualidade oleofílica, ou seja, ele absorve materiais oleosos facilmente.

\subsection{Tecidos de engenharia}

Tecidos de engenharia são produtos fabricados, sobretudo para alto desempenho e obtenção de propriedades funcionais acima de suas características decorativas e estéticas (Pereira, 2005). Na Figura 35 observa-se a construção básica estrutural do tecido de engenharia, mostrando as fibras têxteis no sentido longitudinal (urdume) e no sentido transversal (trama) (Goswami et al., 2004). 


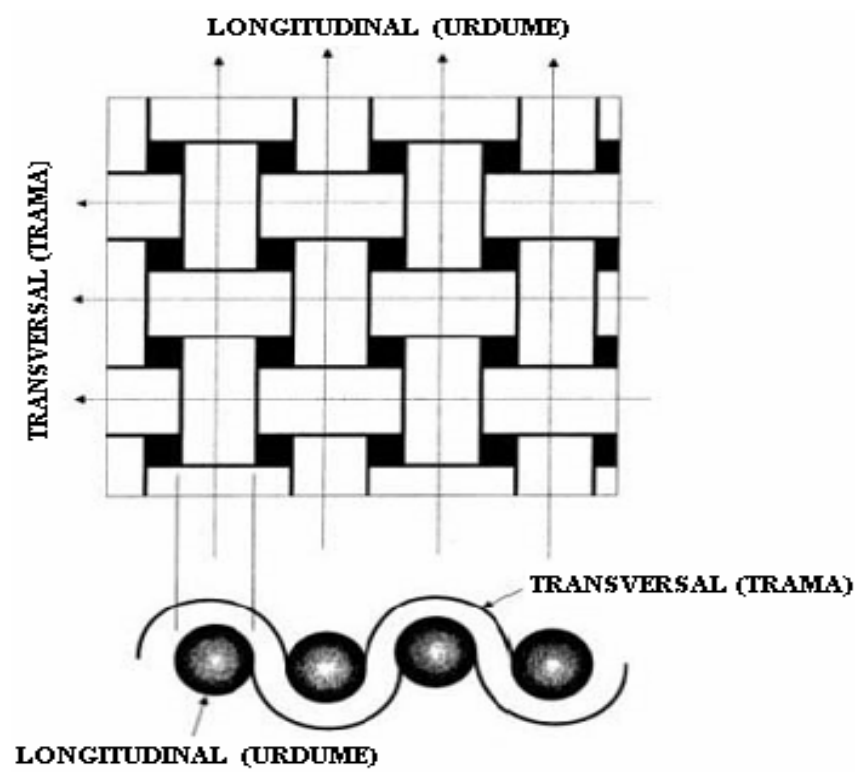

FIGURA 35. Construção básica estrutural do tecido têxtil

Muitos tecidos técnicos consistem da manufatura de fibras montadas, fibras ou tiras de material. Eles têm a sua área superficial substancial em relação a sua espessura e coesão suficiente para atender todos os requisitos de resistência mecânica e solicitações cíclicas.

\subsubsection{Construção de tecidos de engenharia}

As construções básicas mais conhecidas são planas (plain weave), sarja (twill weave) e satim (satin weave). Existem construções a partir das quais muitas novas outras construções são derivadas. O tecido de construção plana é produzido pelo entrelaçamento de dois conjuntos de fibras, normalmente conhecidos como urdume e trama, já citados no item 2.1 (Sen, 2007). Usualmente o urdume está localizado na longitudinal ao longo do comprimento do tecido e a trama na transversal, a $90^{\circ}$ do urdume. Segundo Goswami et al. (2004), embora exista uma ampla variedade de diferentes maneiras para interlaçar dois conjuntos de fibras e produzir diferentes tipos de tecidos estruturais, a construção plana é a mais utilizada.

Tecidos de engenharia de estrutura bidimensional são manufaturados a partir da construção simples sendo pelo menos $90 \%$ do tipo plana. Este padrão de construção é bastante comum e de custo baixo, sendo basicamente constituída pelo movimento alternado das fibras nos sentidos longitudinal e transversal. 
Nas Figuras 36 e 37 são mostrados dois tipos de construção plana com uma e duas fibras intercalados.

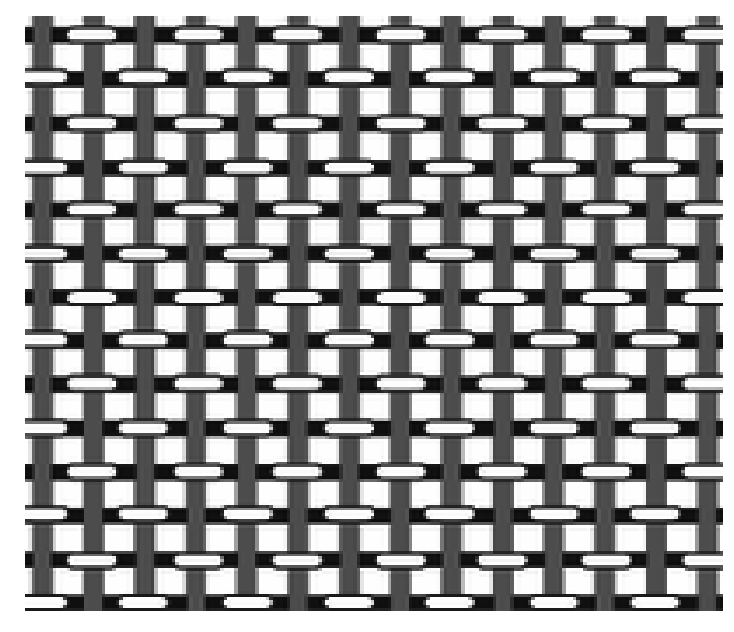

FIGURA 36. Construção plana com uma fibra

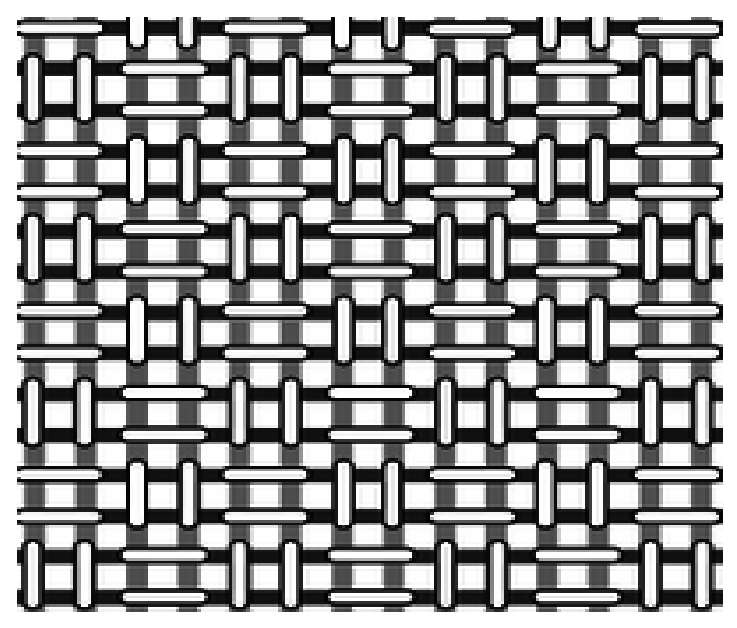

FIGURA 37. Construção plana com duas fibras

O número de estruturas têxteis que podem ser produzidas é praticamente ilimitado, pode-se citar um tipo pouco comum, o tipo giro inglês (leno weave), devido a sua importância nas construções tipo ourela (selvedge) e tecido tri-axial, os quais demonstram simples mudanças estruturais que podem afetar as propriedades físicas dos tecidos.

\subsubsection{Acabamento têxtil em tecidos de engenharia}

Antes do processo de acabamento têxtil, o tecido se encontra no estado chamado cru, ou seja, na sua forma natural. $O$ termo acabamento têxtil abrange uma ampla gama de atividades, as quais são realizadas nos tecidos, como preparação química antes do processamento final. Os principais processos de acabamento disponíveis podem ser divididos em até quatro grupos.

- Processos mecânicos tais como calandragem, angariação, cultivo (cropping) e encolhimento compressivo;

- Estabilização por calor;

- Processos químicos tais como termofixação (dipping);

- Revestimento superficial. 


\subsubsection{Processos de manufatura de produtos de engenharia}

Os processos de manufatura de produtos de engenharia abrangem diversas etapas de fabricação e tratamento do tecido, dentre as quais as principais são: tecelagem, dipagem, calandragem, construção e vulcanização.

\subsubsection{Tecelagem do tecido cru}

A tecelagem é um processo de confecção em que as fibras singelas são processadas para serem transformadas em tecido cru. Estas fibras são montadas para formar o tecido no tear, que é projetado mediante resistência solicitada pelo produto na sua utilização final, conforme mostrado nas Figuras 38 e 39 ( Wootton, 1982).
A Rolo de fibras de urdume
B Varetas tensoras das fibras de urdume
C Batente
D Cala (abertura das camadas das fibras)
E Pente de remate
F Lançadeira (transporta as fibras da trama)
G Tecido
H Rolo de tecido
1 Quadro de liços número 1
2 Quadro de liços número 2

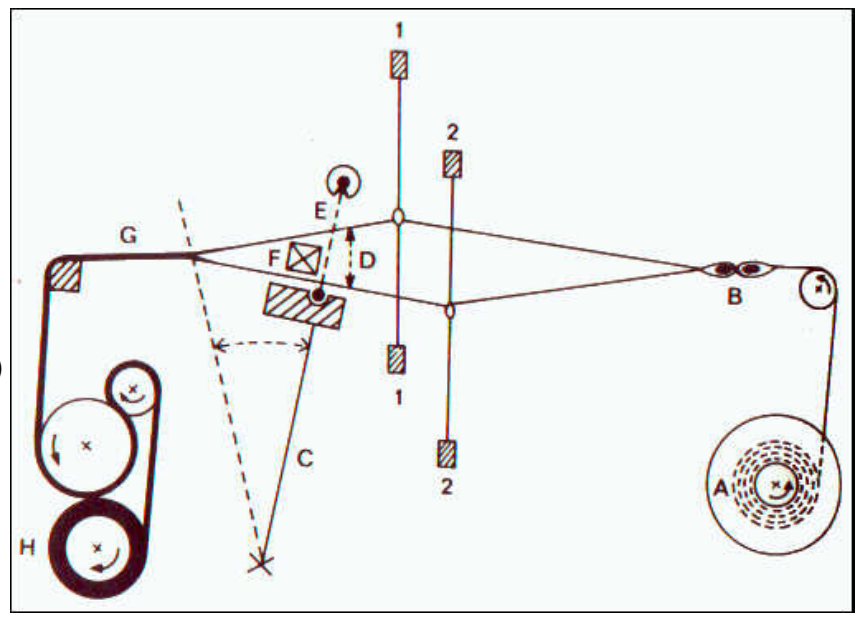

FIGURA 38. Sistema de tear

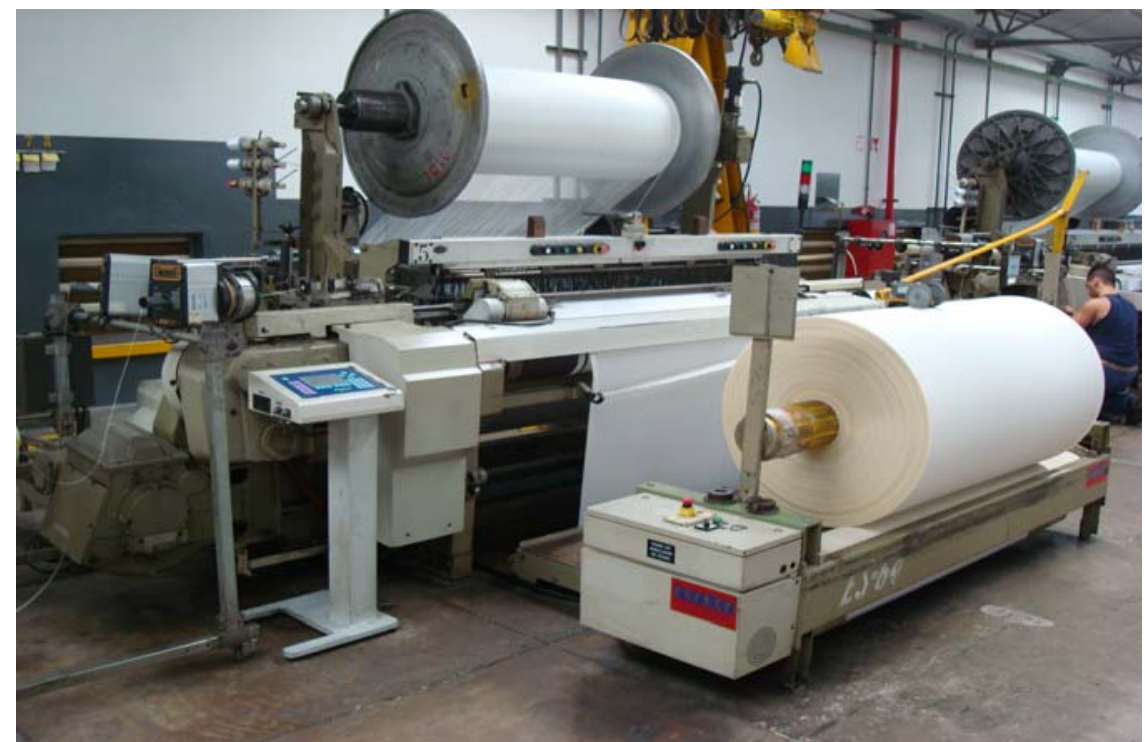

FIGURA 39. Tecelagem

Neste processo, a fibra é submetida a um estado multiaxial composto de tração, compressão, flexão e impacto. 


\subsubsection{Dipagem do tecido cru}

Dipagem é o processo termoquímico pelo qual o tecido cru é submetido a um ou mais banhos de solução à base de água e látex para aderir à borracha. Neste processo o tecido passa por imersão em soluções químicas e é submetido às zonas de aquecimento e secagem para cura, as quais termofixam as fibras do tecido e o tornam quimicamente compatível com a borracha, com a finalidade de obter os valores mínimos de adesão para suportar as solicitações impostas por sua utilização final (Godinho, 2003). Na Figura 40 é mostrado um sistema básico de dipagem utilizado em tecidos.

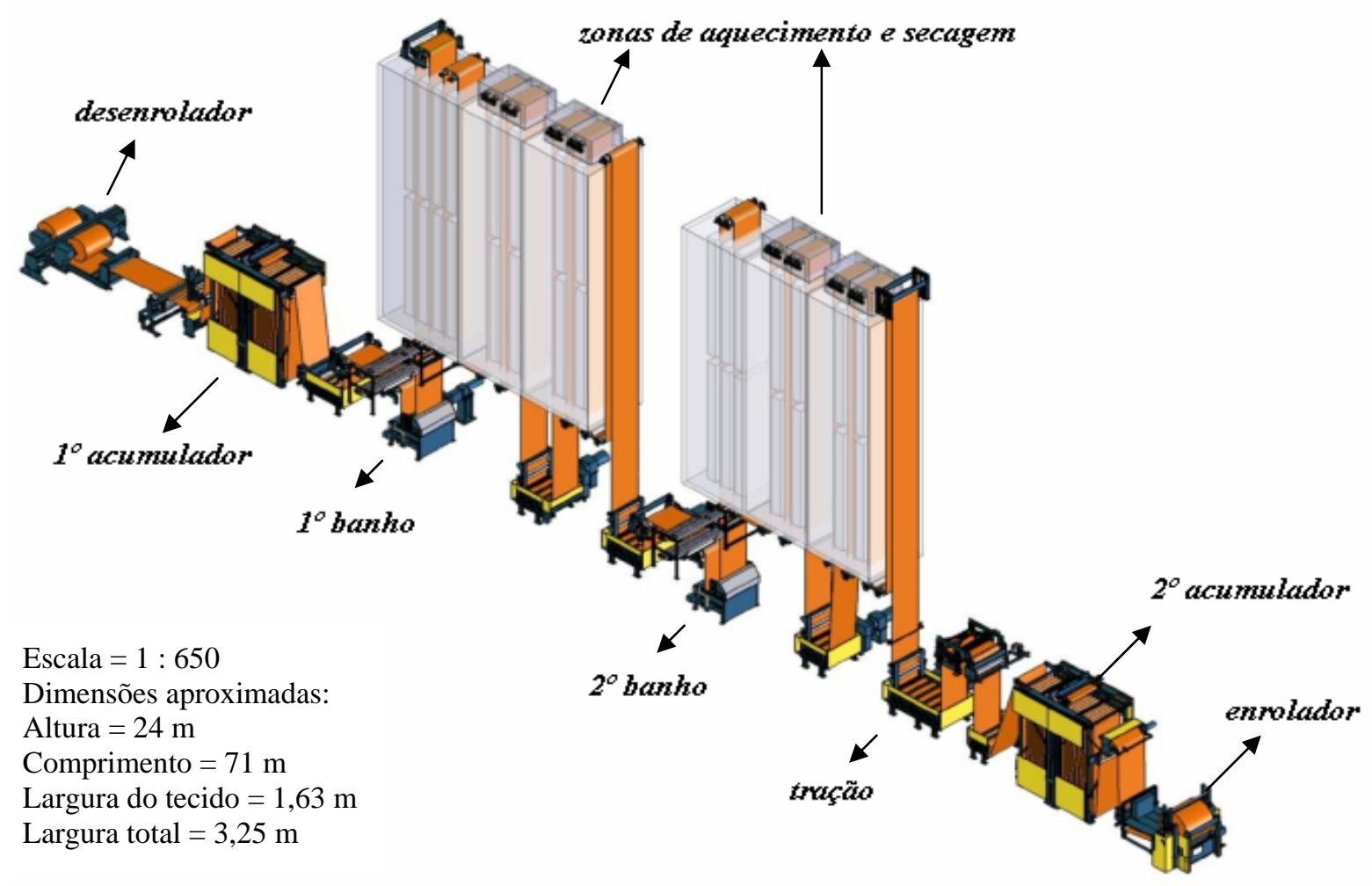

FIGURA 40. Sistema de dipagem para tecidos

Neste processo o tecido cru é submetido a um estado biaxial de tração e flexão com exposição à temperatura da ordem de $185^{\circ} \mathrm{C}$.

\subsubsection{Calandragem do tecido dipado}

Calandragem é o processo de aplicação da borracha no tecido dipado por compressão entre dois rolos; desse processo se origina o tecido emborrachado ou lona (Hall, 2000). Em geral são aplicadas duas camadas, uma camada em cada um dos lados, com espessuras que podem variar de $0,3 \mathrm{~mm}$ a $2,5 \mathrm{~mm}$. 
O tipo da borracha a ser aplicado no tecido vai depender da seleção do tipo de borracha das coberturas a serem utilizadas, ou seja, ambas devem ser compatíveis. Neste processo o tecido no estado dipado é submetido a um estado biaxial de tensões composto de tração e flexão com exposição à temperatura da ordem de $70^{\circ} \mathrm{C}$ (Murphy, 1982).

\subsubsection{Construção da correia crua}

A construção da correia crua é o processo que consiste da montagem do conjunto de tecidos com revestimento de borracha chamado de carcaça e das coberturas de borracha, denominadas de lado transportador de material (geralmente a cobertura com a maior espessura) e lado das polias (lado com a menor espessura).

A etapa inicial da construção ocorre com a montagem de uma ou mais lonas sobre a cobertura, que são comprimidas por um dispositivo denominado calandra, o qual é composto de dois cilindros metálicos, que promovem a adesão entre estes componentes. A partir daí, outros componentes, tais como lonas e coberturas, podem ser adicionados originando a correia transportadora montada no estado inicial cru (Murphy, 1982). Neste processo o tecido emborrachado é submetido a um estado triaxial de tensões composto de tração, flexão e compressão.

\subsubsection{Vulcanização da correia crua}

Conforme já mencionado no item 1.1, a vulcanização é um processo de cura da borracha por enxofre que foi descoberto por Charles Goodyear, em que a correia, originalmente no estado inicial cru, é submetida a uma pressão da ordem de $16 \mathrm{Mpa}$ e a uma temperatura de cerca de $150{ }^{\circ} \mathrm{C}$; podendo variar com o tempo estabelecido em função da espessura e do tipo de borracha das coberturas.

$\mathrm{Na}$ entrada do equipamento de vulcanização existe uma área chamada placa fria onde circula água fria para manter a temperatura em torno de $60^{\circ} \mathrm{C}$ com o objetivo de garantir o equilíbrio térmico entre as duas regiões, ou seja, crua e vulcanizada (Murphy, 1982). Na Figura 41 é mostrado o processo de vulcanização de uma correia transportadora. 


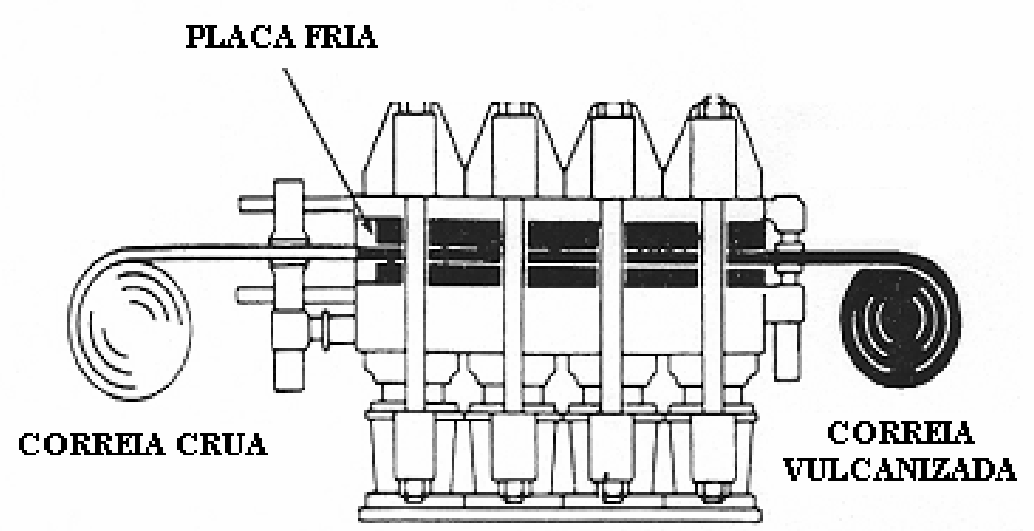

FIGURA 41. Processo de vulcanização de correia transportadora

Neste processo, a carcaça com as coberturas de borracha são submetidas a um estado triaxial de tensões composto de tração, flexão e compressão com temperaturas que podem variar de 150 a $165^{\circ} \mathrm{C}$.

\subsection{Fratura em polímeros}

As propriedades de fratura dos materiais poliméricos têm sido recentemente bastante exploradas, despertando cada vez mais interesse; e os plásticos de engenharia têm sido utilizados em aplicações estruturais de caráter cada vez mais crítico.

\subsubsection{Falhas mecânicas}

A maioria das falhas encontradas nos polímeros é em geral de natureza controlada e a seleção do termo "falhas mecânicas" indica o interesse em ambas as solicitações, estática e dinâmica, responsáveis por esta falhas. Para o projeto apropriado, certamente, é necessário reduzir a possibilidade de fratura de caráter frágil para possivelmente minimizar o efeito de concentração de tensões. Considerando a teoria da fratura de Griffith, é fácil aceitar a ideia de que concentração de tensões em geral é um simples mecanismo de conversão da energia de tensão para a energia da fratura. E a concentração de tensões pode ser desencadeada pelas várias descontinuidades, tais como cavidades, entalhes e, naturalmente, fissuras pontuais. Ao mesmo tempo, a probabilidade de fratura frágil é conhecida por aumentar com o aumento da complexidade de amplas estruturas (Shukla, 2005). 
Nas Figuras 42 e 43 observa-se, de forma esquemática, o surgimento de lacunas durante o carregamento e a propagação da trinca. Isto ocorre devido à propriedade viscoelástica dos polímeros, fenômeno mostrado com maiores detalhes nas Figuras 44 a 46 (Anderson, 2005).

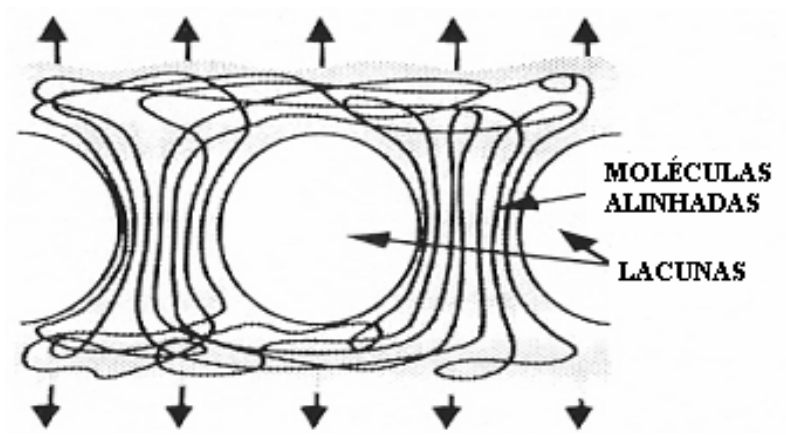

FIGURA 42. Lacunas no carregamento

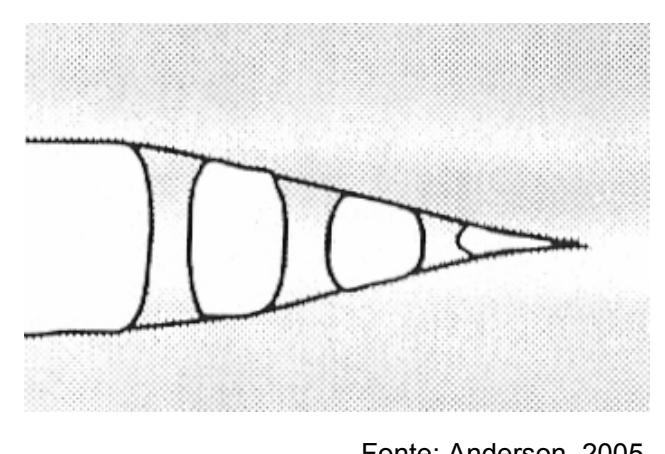

FIGURA 43. Lacunas da trinca

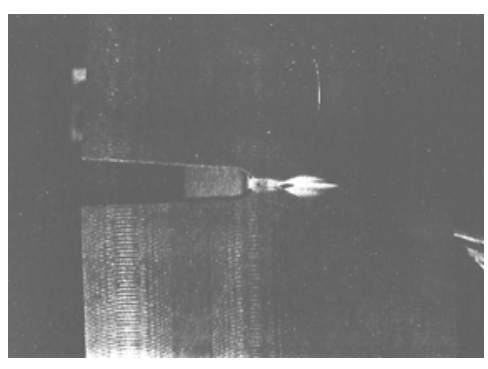

FIGURA 44. Início da trinca

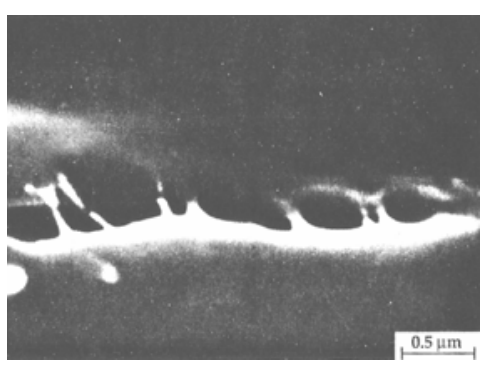

FIGURA 45. Propagação

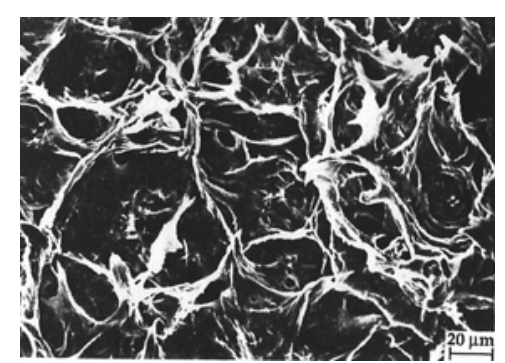

Fonte: Anderson, 2005.

FIGURA 46. Face da fratura

Em 1983, o NIST (National Institute of Standards and Technology) e o Battelle Memorial Institute estimaram os custos ocasionados por falha de materiais e componentes devido à fratura em torno de 119 bilhões de dólares por ano. Os dólares são importantes, mas o custo de muitas falhas na vida humana não tem preço. Falhas têm ocorrido por diversas razões, incluindo incertezas no carregamento, defeitos nos materiais, projeto inadequado e deficiência na construção ou manutenção (Roylance, 2001).

\subsubsection{Fratura em materiais poliméricos}

As principais causas de fratura em peças de polímeros são as ações prolongadas da tensão constante (deformação à ruptura), a aplicação da tensão em um pequeno período de tempo (impacto), e a aplicação contínua de tensões cíclicas (fadiga). 
Em todas as causas o processo de falha será acelerado se o plástico estiver em um ambiente agressivo. São dois os tipos básicos de fratura sob tensão mecânica, os quais são reconhecidos: a fratura dúctil e a fratura frágil. Estes termos se referem ao tipo de deformação que caracteriza a fratura. Fraturas frágeis são potencialmente mais perigosas porque ocorrem sem observar a deformação inicial do material. Na fratura dúctil, por outro lado, grandes deformações ocorrem antes que a ruptura venha a ocorrer e servem como uma valiosa advertência. $O$ material absorve mais energia quando a fratura ocorre no modo dúctil do que no modo frágil. Na Figura 47 são mostradas as curvas típicas de tensão-deformação para materiais poliméricos dos tipos frágil e dúctil (Riande et al., 1999).

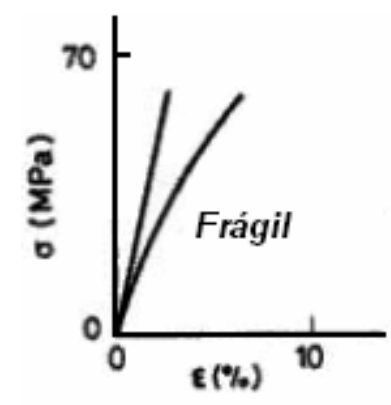

(a)

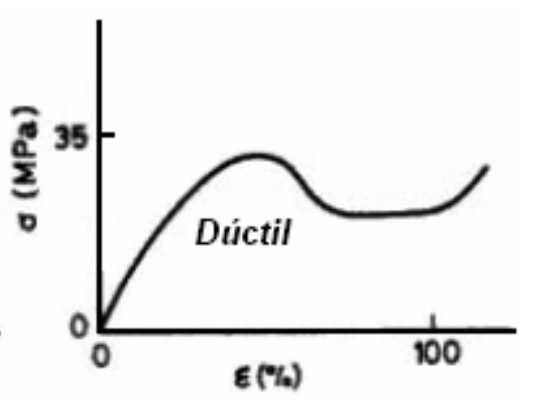

(b)

FIGURA 47. Curvas típicas de tensão-deformação para materiais poliméricos

Nos materiais poliméricos, portanto, a fratura pode ocorrer de modo dúctil ou frágil e, dependendo das variações, o mais importante é como serão a taxa de deformação, o sistema de tensão e temperatura. Ambos os tipos de falha podem deste modo ser observados em um material, dependendo das condições de serviço.

\subsubsection{Mecanoquímica macromolecular do polímero}

Mecanoquímica é uma ciência que está localizada e foi inicialmente desenvolvida na fronteira entre as ciências mecânica e química. Ao mesmo tempo, a mecanoquímica está relacionada com a física, especialmente com a física dos sólidos, a biofísica, substâncias inorgânicas e com a biologia bioquímica e molecular. Geralmente, a mecanoquímica deve ser considerada como a ciência de transformações mútuas (recíprocas) de energias química e mecânica, com a ocorrência de todos os tipos de substâncias. 
No presente momento, o termo mecanoquímica é usado em muitos campos de atividade, mas, muitas vezes, tendo um teor diferente. Por exemplo, a mecanoquímica macromolecular foi definida como a parte da química do polímero em que ocorre a iniciação e aceleração de transformações químicas, as quais ocorrem nas poliestruturas, como resultado da energia absorvida de maneira elástica.

Por outro lado, a direta conversão de energia química em trabalho mecânico é estudada por quimiomecânicos. Baramboin (1978) definiu mecanoquímica como a ciência que trata da investigação das transformações químicas de substâncias que ocorrem sob o efeito de forças mecânicas. A bioquímica, a bioquímica molecular e a fisiologia, em termos de mecanoquímica, estão associadas com produção de energia mecânica por reações químicas, que ocorrem em corpos vivos.

Processos mecanoquímicos consistem na sequência intercalada de fenômenos físicos e químicos, os quais regem a mudança de estrutura e propriedades/funções de suporte macromolecular em que ocorrem. O processo afeta todos os níveis de organização estrutural e esta complexidade aumenta igualmente a ampliação da complexidade do suporte macromolecular e interações do meio.

Ao lado da mecanoquímica de polímeros e da biomecanoquímica, estudos muito importantes relativos a mecanoquímica e mecanoemissão de corpos sólidos têm também sido desenvolvidos. O estudo das características básicas de multiestágio de processos mecanoquímicos, aplicados para materiais fibrosos em condições de alta intensidade de deformação até o campo das forças variáveis (por exemplo, fresagem vibratória), demonstra que o passo determinante é a mecanotrinca, a qual é concluída por um mecanismo de mecanodegradação.

O mais importante resultado da mecanodegradação é a redução do grau de polimerização, que também favorece a fratura macroscópica, consistindo do decréscimo das dimensões geométricas das partículas; este processo é chamado mecanodispersão. Portanto, as fibras são convertidas em partículas com tamanhos variando tomando-se por base várias dezenas de mícrons. A amorfização do material ocorre ao nível da estrutura amorfo-cristalina. Este fenômeno foi provado por investigações por raios $\mathrm{X}$. 
Em outras palavras, mecanodegradação e mecanodispersão são processos interconectados e fechados, tendo como efeito final a redução do grau de polimerização, no nível molecular, e o aumento da superfície, em um nível morfológico.

O estágio de mecanoativação tem lugar a uma taxa muito mais baixa que os outros passos do processo multiestágio e, consequentemente, isto não pode ser claramente distinguido. Nas Figuras 48 e 49 são mostrados os mecanismos de geração da microtrinca nascente e da trinca principal.

$\sigma \boldsymbol{t}$

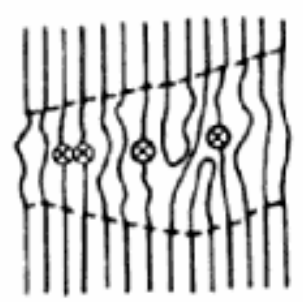

$\sigma \downarrow$ $\sigma \uparrow$

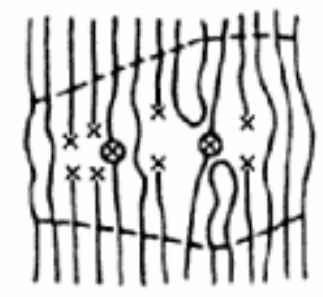

$\sigma \downarrow$

II

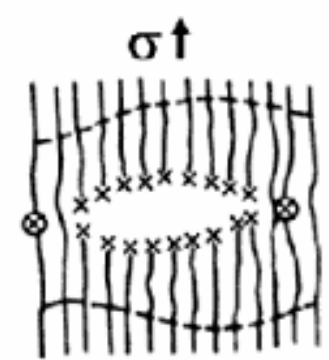

$\sigma_{\downarrow}$

I - Macromoléculas mecanoexcitadas

II - Formação dos primeiros radicais livres

III - Microtrinca nascente localizada no nível da falha estrutural

FIGURA 48. Mecanismo de geração da microtrinca nascente

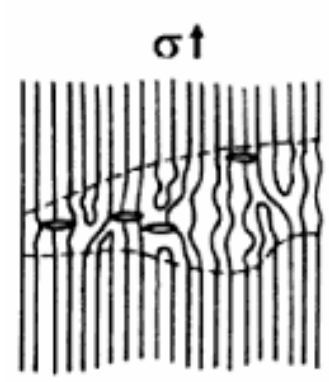

$\sigma \downarrow \mid$

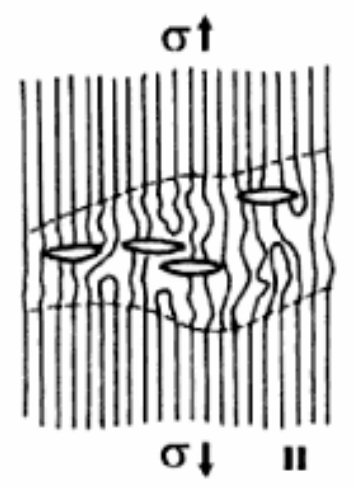

$\sigma_{\downarrow}$
11

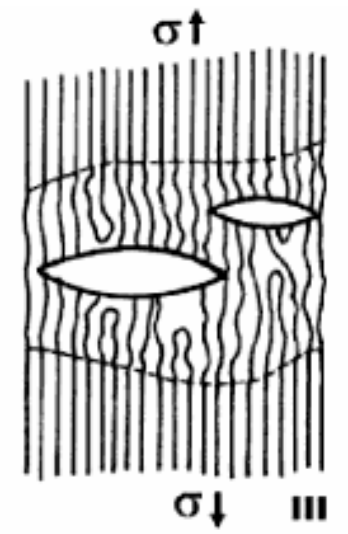

$\sigma \downarrow \quad$ III

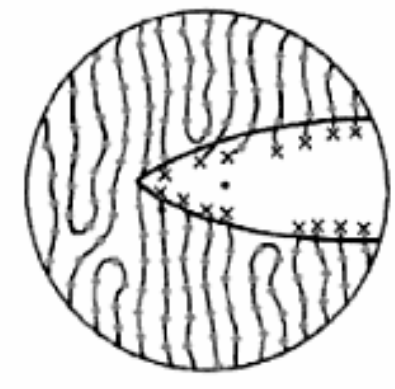

IV

I - Nucleação das microtrincas nascentes

II - Crescimento por nucleação individual das microtrincas

III - Crescimento por coalescência de diversas trincas

IV - Propagação da trinca principal demonstrando radicais livres na sua frente

FIGURA 49. Mecanismo de geração da trinca principal 
Independentemente dos estágios dos processos mecanoquímicos, um número de radicais livre surge; estes radicais podem iniciar muitas reações químicas, tais como enxerto, copolimerização em bloco, entre outras. Em adição, a estabilização de radicais livres é demonstrada pela formulação de novos grupos funcionais, que sejam capazes de promover as reações de policondensação e/ou complexação (Vasiliu-Oprea; Dan, 2003).

\subsubsection{Fratura de fibras têxteis}

A fratura de fibras têxteis processadas por fiação por fusão é dominada pelo escoamento. A secção de fratura de materiais poliméricos dúcteis mostra claramente o mecanismo de propagação da trinca até a ruptura. A secção de fratura do tipo frágil normalmente ocorre em materiais poliméricos com maior rigidez tais como fibras de vidro, cerâmica, carbono, entre outros. A fratura de fibras sob várias condições demonstrou que a tensão de ruptura depende do diâmetro, o que é consistente com a relação de Griffith.

\subsubsection{Fratura a alta velocidade de fibras têxteis}

As mudanças mais dramáticas em uma fratura ocorrem a velocidades altas, tais como podem ser impostas por uma queda pendular com fraturas em frações de segundo ou ainda mais rápido com impacto balístico. A razão para a diferença entre fraturas rápidas e lentas é a mudança das condições de isotérmicas para adiabáticas.

\subsection{Caracterização das fibras têxteis}

A caracterização de microestrutura de fibras poliméricas pode proporcionar discernimentos sobre as estruturas fundamentais presentes e sobre a relação entre a estrutura e importantes propriedades para as aplicações desejadas. A caracterização morfológica fornece informação para auxiliar na compreensão dos efeitos do histórico de processamento mecânico e outras propriedades físicas. Técnicas microscópicas são utilizadas para observar características tais como forma da fibra, diâmetro, estrutura (tamanho cristalino, vazios, entre outros), orientação molecular, tamanho e distribuição de aditivos, estrutura da fibra, montagem do tecido e falhas mecânicas. Estas características estão diretamente relacionadas a determinadas propriedades mecânicas e térmicas. 
Os polímeros utilizados nas fibras são lineares, portanto, as moléculas possuem alguns poucos nanômetros na secção e várias centenas de nanômetros no comprimento. Em materiais sem orientação, as moléculas são espiraladas e entrelaçadas em esferas isotrópicas livres.

Quando a fibra é orientada, por estiragem (drawing), por exemplo, as cadeias moleculares tornam-se alinhadas paralelamente ao eixo da fibra (orientação uniaxial da fibra) e a rigidez e resistência aumentam. Em muitas fibras, as moléculas são espiraladas e entrelaçadas, embora estejam orientadas. Somente em fibras de ultra-alto módulo ou em fibras formadas de líquido cristalino precursor as moléculas são altamente delgadas e alongadas paralelamente ao eixo da fibra. O elemento básico de fibras semicristalinas é a microfibrila, a qual pode ser encontrada em feixes de fibrilas com cerca de várias centenas de nanômetros de espessura.

As fibras têxteis sintéticas e naturais estavam entre os primeiros materiais estudados por microscopia eletrônica. A estrutura e as propriedades das fibras de náilon 6 e do polietileno tereftalato (PET) foram aprofundadas usando ambas as técnicas de microscopia eletrônica e espalhamento de pequeno ângulo (small angle scattering, SAS).

\subsubsection{Microscopia ótica de fibras têxteis}

A microscopia ótica (MO) é usada para estudar várias características da fibra, como tamanho, secção transversal, uniformidade, orientação molecular e distribuição de cargas. A birrefringência é a diferença entre o índice refractométrico paralelo e perpendicular ao eixo da fibra; é uma medida quantitativa importante de orientação molecular. A combinação entre medições de birrefringência e outras técnicas tem sido demonstradas. Medições por birrefringência são efetivas em proporcionar parâmetros estruturais, os quais podem ser utilizados para relacionar variáveis de processo com as propriedades mecânicas (Sawyer; Grubb, 1996). 


\subsubsection{Microscopia eletrônica de varredura em fibras têxteis}

A microscopia eletrônica de varredura (MEV) tem comprovado ser um instrumento muito útil para a avaliação da morfologia da fibra. As imagens tridimensionais produzidas demonstram claramente as características superficiais, tais como a presença de modificações superficiais, aplicações de acabamento, natureza do desgaste e causas das falhas. A grande profundidade do raio visual, simples preparação da amostra e alta resolução têm tornado a MEV a maior contribuição para o estudo de fibras têxteis. Fibras têxteis geralmente têm um acabamento superficial aplicado após a fiação para auxiliar no tratamento das fibras para produção das fibras e tecidos. As fibras são rompidas e examinadas por MEV para avaliar a natureza do mecanismo de falha e para identificar a localização da causa da falha (Sawyer; Grubb, 1996). Na Figura 50 é ilustrado o sistema de funcionamento de um microscópio eletrônico de varredura convencional.

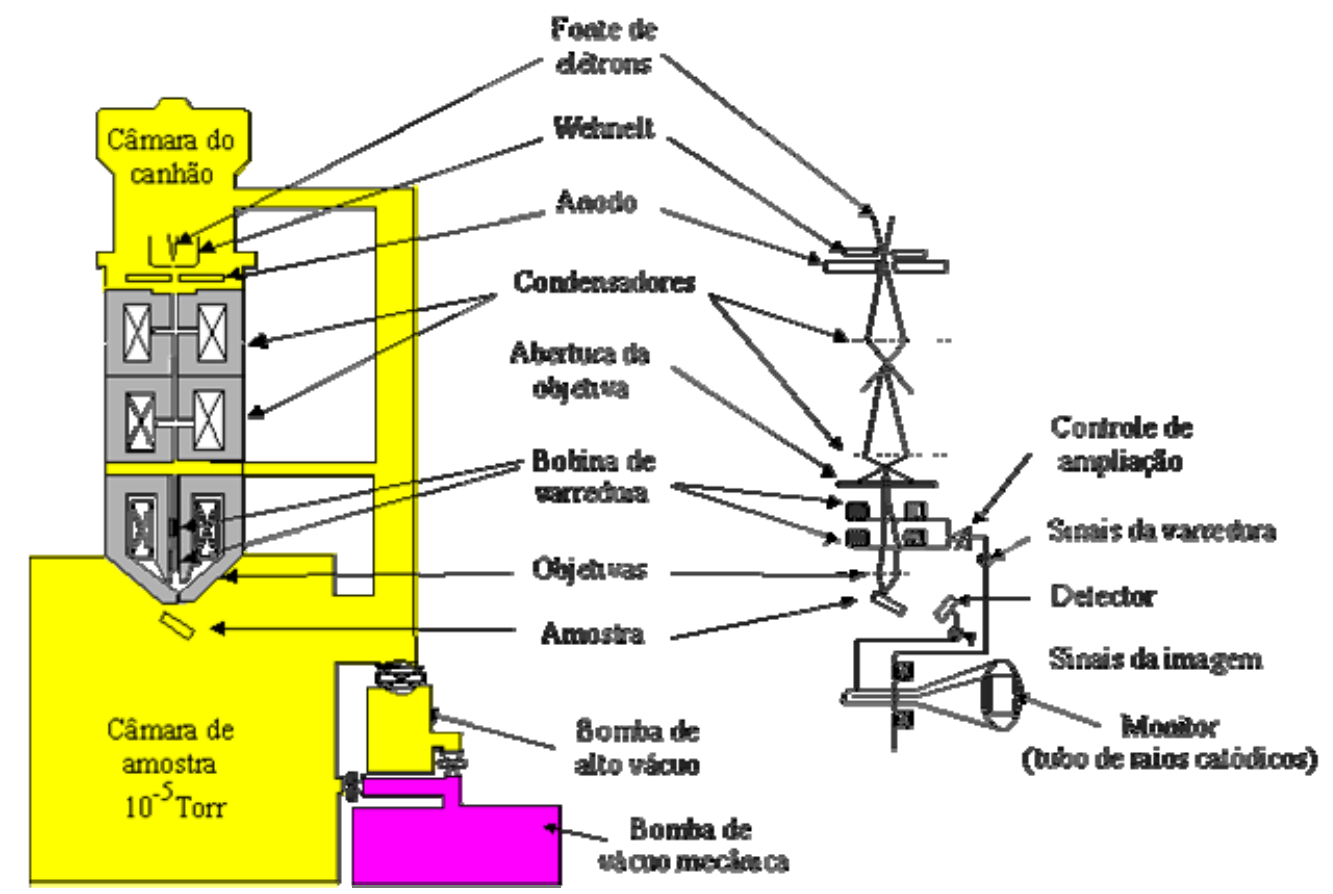

Figura 50. Microscópio eletrônico de varredura convencional

Como exemplo, a avaliação fractográfica por microscopia para fibras de ligações cruzadas (crosslinked) demonstrou uma mudança na morfologia da fratura de fibrilar para um mecanismo frágil. 


\subsubsection{Microscopia eletrônica de transmissão em fibras têxteis}

Técnicas de microscopia eletrônica de transmissão (MET) são muito importantes para a elucidação de detalhes da microestrutura da fibra. Os tipos de detalhamento da estrutura determinados pela MET são:

- Estrutura do polímero;

- Tamanho de vazios, forma e distribuição;

- Tamanho, forma e distribuição de cargas;

- Cristalinidade localizada;

- Tamanho do cristalito.

Estudos microestruturais geralmente requerem complementação por estudos ópticos e MEV para compreender o arranjo de detalhes estruturais finos no interior da macroestrutura (Sawyer; Grubb, 1996). 


\subsection{Análise por elementos finitos}

A análise por elementos finitos ou finite elements analyse (FEA) é uma ferramenta importante para analisar as tensões máximas que ocorrem em uma correia transportadora, durante a sua utilização. Na figura 51 é mostrado um modelamento feito em uma correia transportadora com auxílio do programa para análise por elementos finitos.

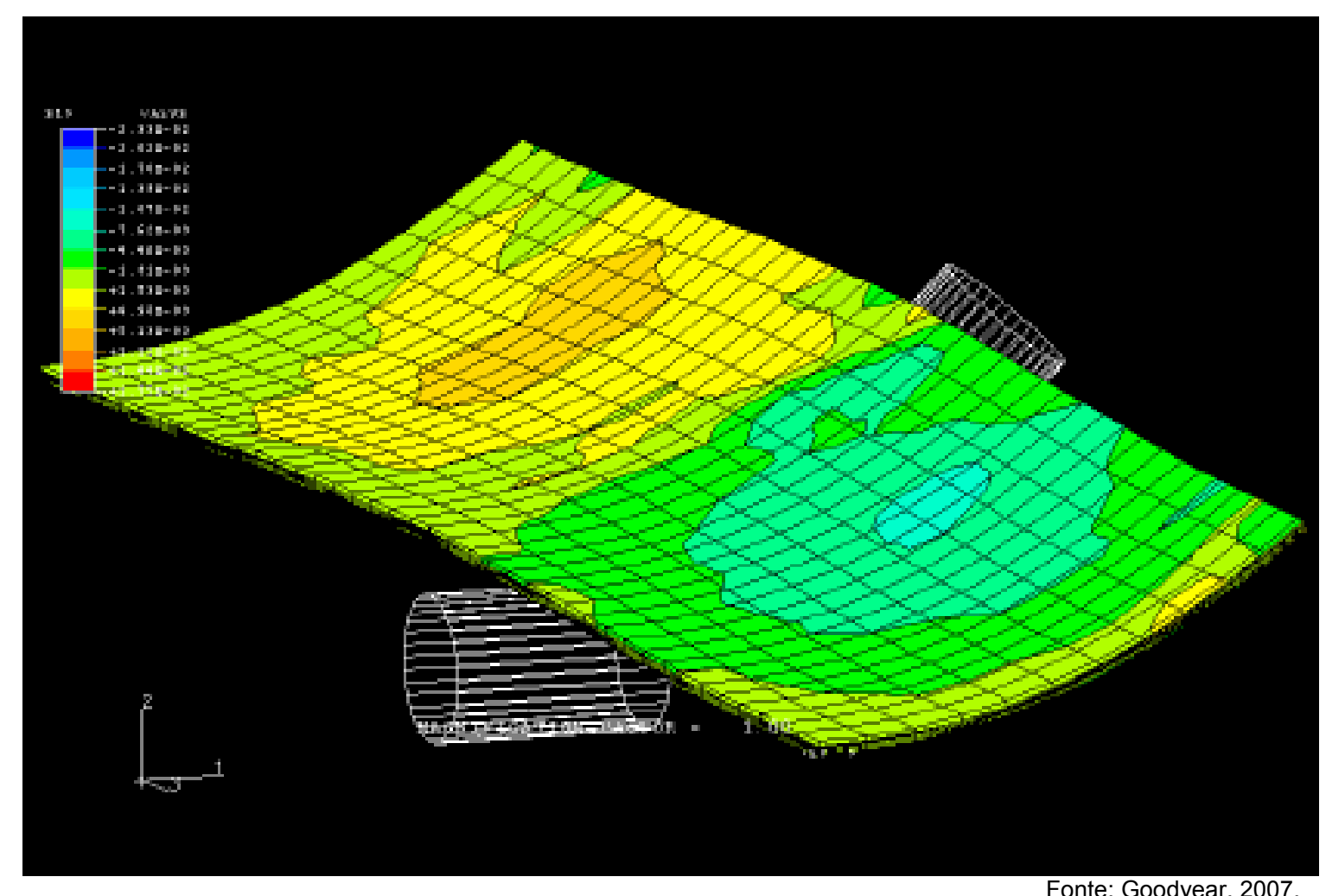

FIGURA 51. Modelamento de uma correia transportadora

Para análise, as amostras de fibras são submetidas a tensões biaxiais e o modelamento é efetuado com o auxílio de um programa de análise por elementos finitos, normalmente o Ansys, Nastran ou Abacus. 


\section{MATERIAIS E MÉTODOS}

\subsection{Materiais}

Entre os diversos tipos de fibras utilizadas na estrutura de elementos dinâmicos, tais como pneus, correias, molas pneumáticas e mangueiras de condução de fluidos, os materiais selecionados para o presente estudo são o náilon 6.6 e o poliéster. O motivo para a seleção é a ampla utilização e aplicação destas fibras em todos os elementos dinâmicos citados. Para esta finalidade foram selecionadas quatro amostras de correias transportadoras de granulados denominadas com as letras "A e B" (reforço estrutural do tipo náilon) e letras "C e D" (reforço estrutural do tipo poliéster), procedimento já mencionado no item 1.2.

\subsection{Métodos}

Os métodos utilizados para a análise das fibras foram constituídos de ensaios analíticos e destrutivos das fibras e tecidos, ensaio de tração monitorada, análise por microscopia eletrônica de varredura, ensaios de adesão interfacial e desenvolvimento teórico.

\subsubsection{Ensaios analíticos e destrutivos nas fibras de náilon e poliéster}

Inicialmente foram extraídas amostras dos tecidos após todas as etapas de processamento com a posterior realização dos ensaios dimensionais, contagem das fibras, peso específico, encolhimento, torção e por fim tração, com equipamentos próprios para esta finalidade. A figura 52 mostra o dispositivo utilizado para medição da torção das amostras das fibras processados após a etapa do processamento de torção. Na Figura 53 é mostrado o dispositivo utilizado para medição da taxa de encolhimento da fibra antes do inicio do processamento. Nas Figuras 54 e 55 é mostrado o aparelho utilizado para a contagem das fibras do urdume do tecido após a etapa de construção. Na figura 56 é mostrado como foram extraídas as fibras do tecido dipado. 
Na Figura 57 é mostrada a máquina de tração utilizada para o estudo das propriedades das fibras. Nas Figuras 58 e 59 são mostradas as garras especificas utilizadas para o ensaio de tração das amostras das fibras.

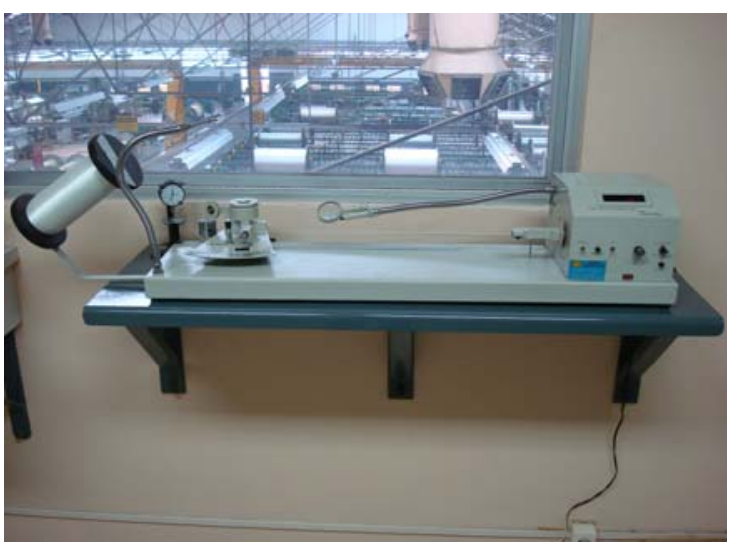

FIGURA 52. Torção da fibra

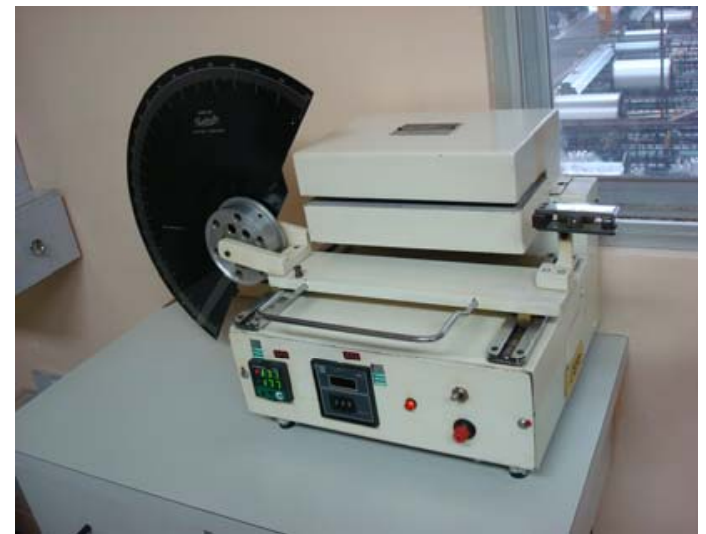

FIGURA 53. Encolhimento da fibra

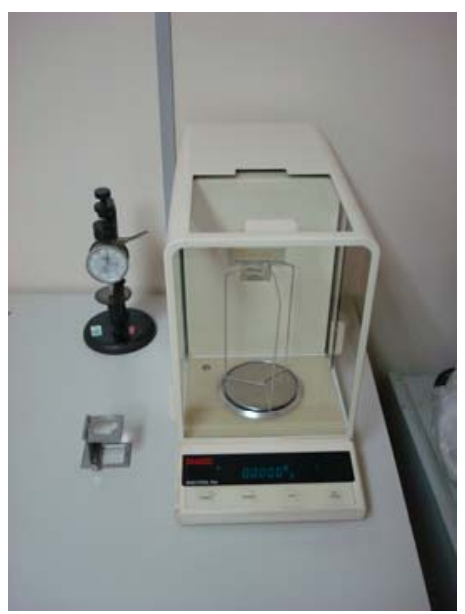

FIGURA 54. Peso, calibre e contagem

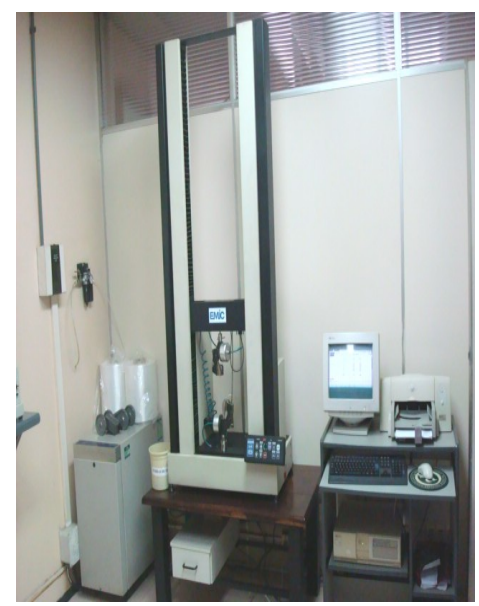

FIGURA 57. Ensaio de tração

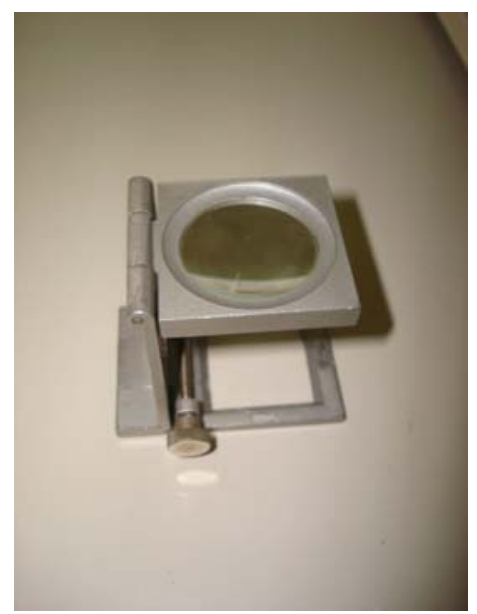

FIGURA 55. Detalhe contagem

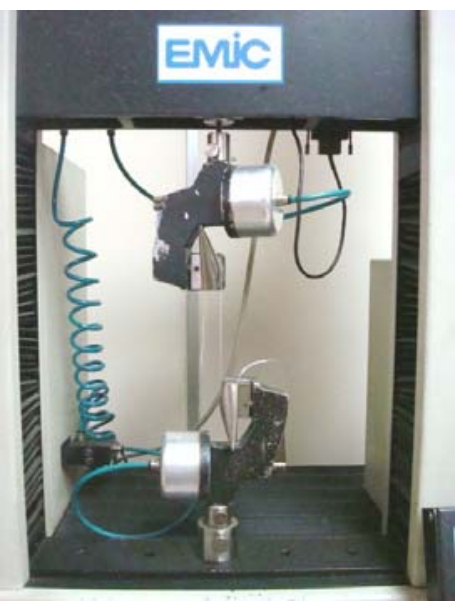

FIGURA 58. Tração fibra singela

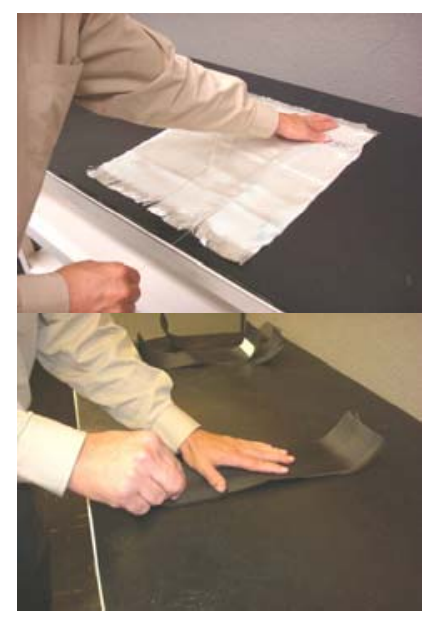

FIGURA 56. Extração das fibras

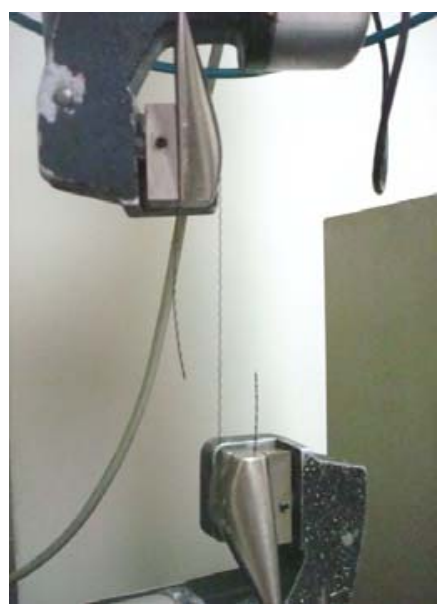

FIGURA 59.Tração fibra dipada 


\subsubsection{Ensaio de tração monitorado da fibra com ajuste de tensão manual}

O método de ensaio de tração monitorado com ajuste da tensão aplicada nas fibras foi desenvolvido em razão da dificuldade para detecção da sequência de fratura dos filamentos nas fibras, durante o ensaio de tração ou mesmo na análise de microscopia eletrônica de varredura, pela dispersão dos filamentos após o ensaio de ruptura. O método consiste no uso de um dispositivo projetado com roldanas giratórias e cilindros fixos, com espaçamento de $200 \mathrm{~mm}$ entre os pontos de fixação, o mesmo padrão utilizado na máquina de teste de tração, nos quais são fixadas as fibras e, com ajuda de ferramentas para controle de movimento e travamento em diferentes posições, as mesmas são tensionadas manualmente. 0 monitoramento foi realizado com auxílio de uma lupa com ampliação de três vezes e uma base apoiada no dispositivo com uma face na cor branca e a outra face na cor preta, e, caso a fibra seja singela, torcida, construída, dipada ou vulcanizada, utiliza-se das cores do fundo para melhor visualização do mecanismo de ruptura. A partir daí, por meio da taxa de alongamento até a ruptura de cada fibra, foi possível determinar aproximadamente a carga aplicada pelo deslocamento circular da roldana. Para este ensaio foram selecionadas amostras de fibras de poliéster do tipo singelo devido à maior facilidade de visualização da sequência da fratura. Segue a continuação exemplo da sequência de cálculo para $80 \%$ de carga aplicada para a fibra de poliéster, procedimento que será mostrado nas Figuras 87 e 88 :

- Comprimento inicial => $200 \mathrm{~mm}$;

- Comprimento final aproximado => $230 \mathrm{~mm}$;

- Alongamento à ruptura do poliéster => 15\% ou $30 \mathrm{~mm}$ de deslocamento;

- Diâmetro da roldana => $10 \mathrm{~mm}$;

- Uma volta da roldana equivale a aproximadamente 31,416 mm;

- Deslocamento da roldana até a ruptura da fibra => $30 / 31,416=>0,955$ volta;

- $80 \%$ da carga máxima de ruptura equivale a 0,955 x 0,80 => 0,764 volta.

Com base nos dados anteriores, sabe-se que a fibra de poliéster rompeu a aproximadamente 0,955 volta da roldana, portanto $80 \%$ da carga máxima de ruptura equivale a um deslocamento circular da roldana em torno de 0,764 volta, ou seja, $0,764 \times 31,416=>24 \mathrm{~mm}$. 
Nas figuras 60 a 62 são mostrados o dispositivo e o método utilizado para monitoramento do ensaio de tração.

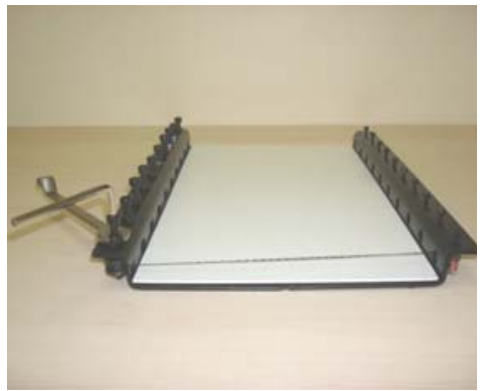

FIGURA 60. Fibra dipada

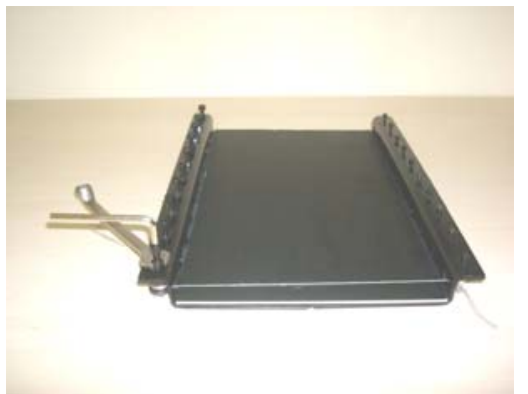

FIGURA 61. Fibra torcida

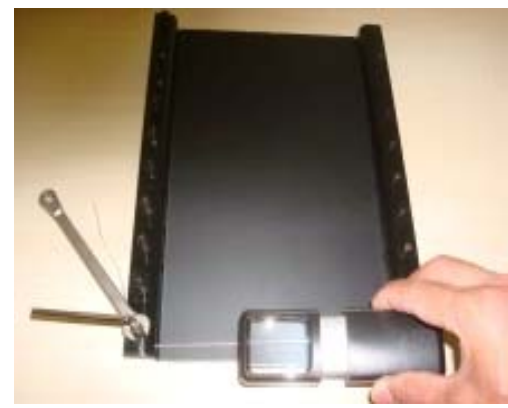

FIGURA 62. Monitoramento

\subsubsection{Ensaios de tração monitorado no tecido}

O método utilizado para os ensaios de tração dos tecidos de náilon e poliéster seguiu a norma ISO 283, $3^{a}$ edição de 2007 , onde foram extraídas amostras após a etapa de dipagem, com a posterior realização dos ensaios com monitoramento visual. Para este ensaio foram selecionadas amostras dipadas devido à maior facilidade de visualização da sequência da fratura. Nas Figuras 63 a 71 mostram a sistemática utilizada para a confecção das amostras.

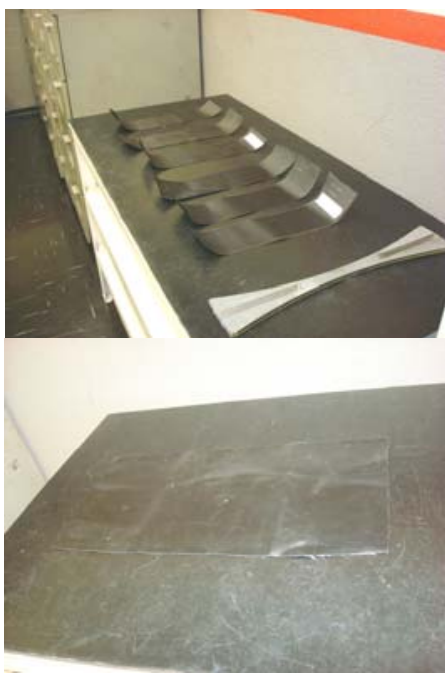

FIGURA 63. Tecido e tratamento

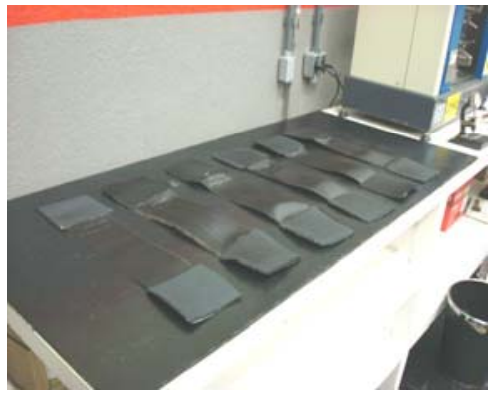

FIGURA 66. Amostras vulcanizadas

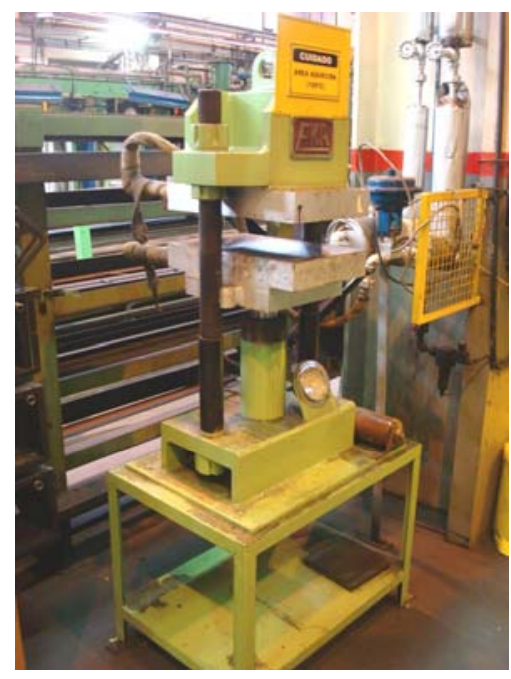

FIGURA 64. Prensa de Vulcanização

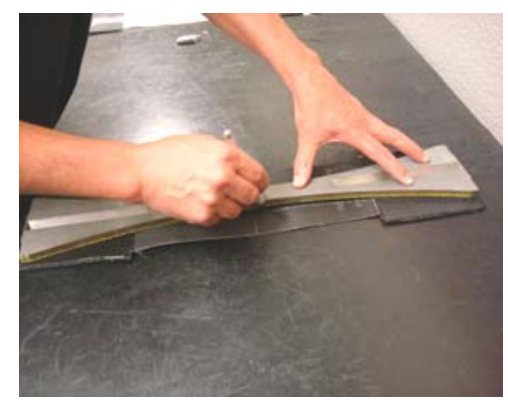

FIGURA 67. Marcação do arco

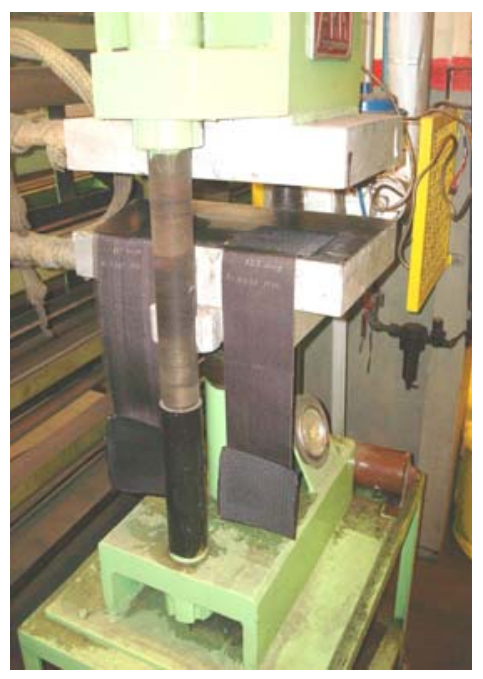

FIGURA 65. Preparação

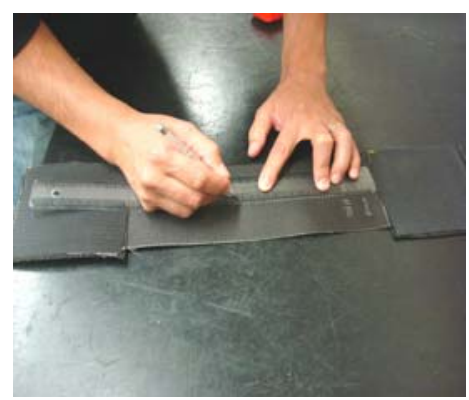

FIGURA 68. Marcação do centro 


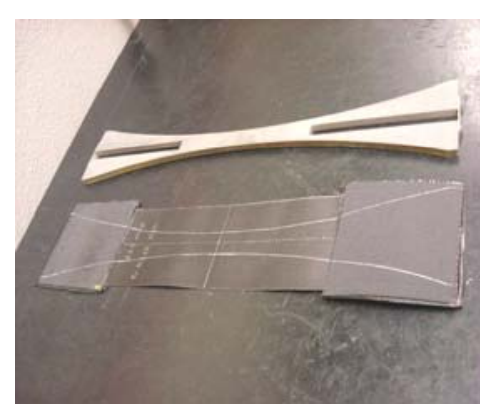

FIGURA 69. Perfil traçado

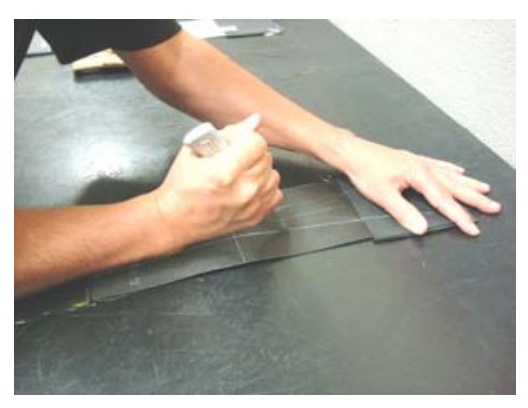

FIGURA 70. Corte da amostra

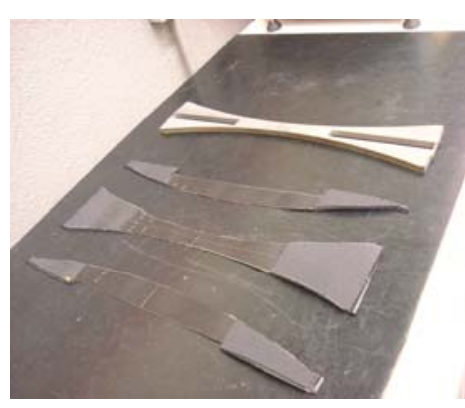

FIGURA 71. Amostra cortada

\subsubsection{Microscopia eletrônica de varredura}

Conforme já mencionado no item 2.5, a microscopia é uma técnica usada para observar características tais como forma da fibra, diâmetro, estrutura (tamanho cristalino, vazios, entre outras), orientação molecular, tamanho e distribuição de aditivos, estrutura e montagem do tecido e mecanismo de falha. Estas falhas são diretamente relacionadas a determinadas propriedades térmicas e mecânicas (Sawyer; Grubb, 1996).

A preparação de amostras de fibras para a MEV é relativamente simples, especialmente se comparada à preparação para a MET, mas isto deve ser realizado com cautela, uma vez que mesmo simples técnicas de preparação, se mal elaboradas, resultam em micrografias ruins ou interpretações errôneas. Devido à má condutividade de muitos polímeros, uma camada de material condutivo deve ser aplicada a sua superfície antes de iniciar a análise por MEV.

Amostra com má condutividade causa acúmulo de elétrons na superfície, produzindo variações na superfície ou carregamento. O carregamento se manifesta como várias distorções na imagem e brilho excessivo, que impede a produção da imagem real. Condutividade ruim também reduz a dissipação térmica, que pode levar a movimentação da amostra ou mesmo falha por aquecimento. Além disso, os polímeros, que são usualmente materiais de baixa densidade atômica, são facilmente penetrados pela alta voltagem elétrica, causando perda de detalhes superficiais. Revestimento com uma microcamada metálica é um método amplamente utilizado para suprimir o carregamento e reduzir a penetração do feixe de elétrons (Raheel, 1999). 
A baixa penetração do feixe é especialmente importante nos polímeros, desde a emissão eletrônica secundária (aqueles elétrons emitidos pela amostra durante o bombardeamento do feixe eletrônico), até o seu principal modo de geração da imagem e a profundidade de penetração, que reduz o número de elétrons superficiais secundários produzidos (Raheel, 1999).

As análises por microscopia eletrônica de varredura foram realizadas mediante a norma ASTM D276 de 2008 em equipamentos e procedimentos adequados para análise de fibras têxteis. A preparação das amostras consistiu na metalização com ouro e análises no microscópio eletrônico de varredura. A observação foi realizada com tensões de aceleração mais baixas (15 kV) se comparadas àquelas usadas para ligas metálicas. Nas figuras 72 a 76 são mostrados a metodologia e os equipamentos utilizados para este estudo.

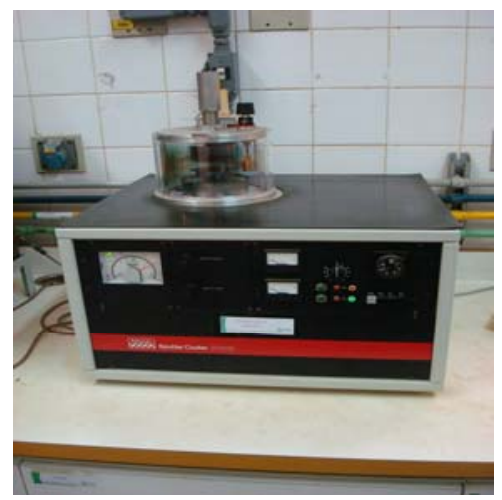

FIGURA 72. Metalizador

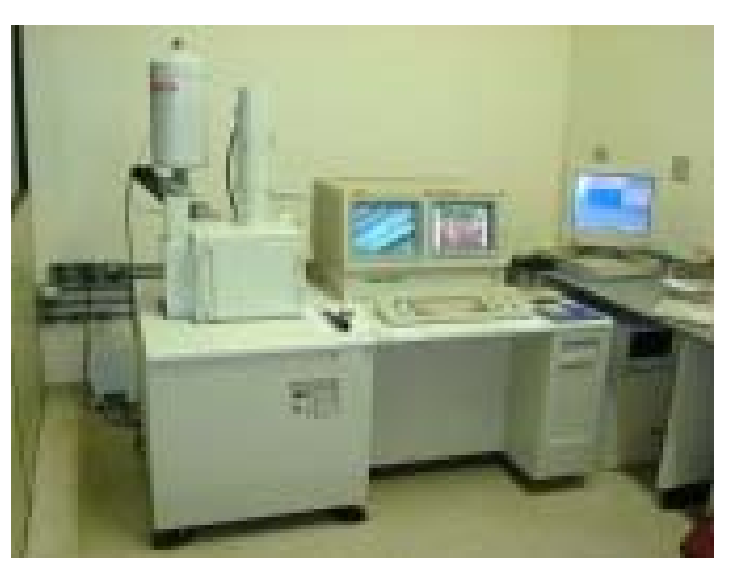

FIGURA 75. Microscópio eletrônico de varredura

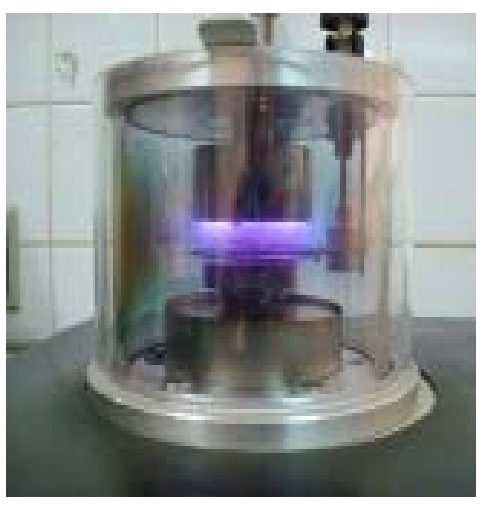

FIGURA 73. Metalização

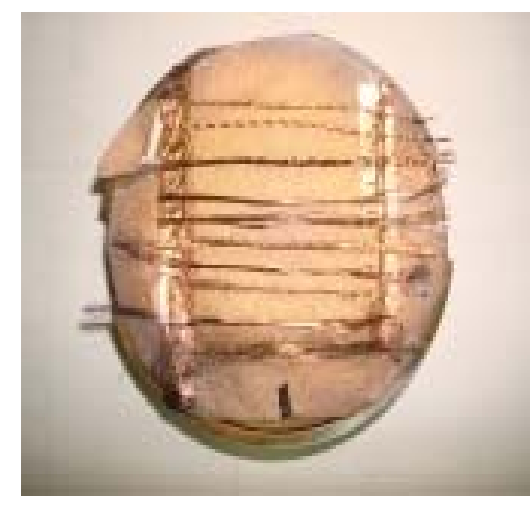

FIGURA 74.Amostras metalizadas

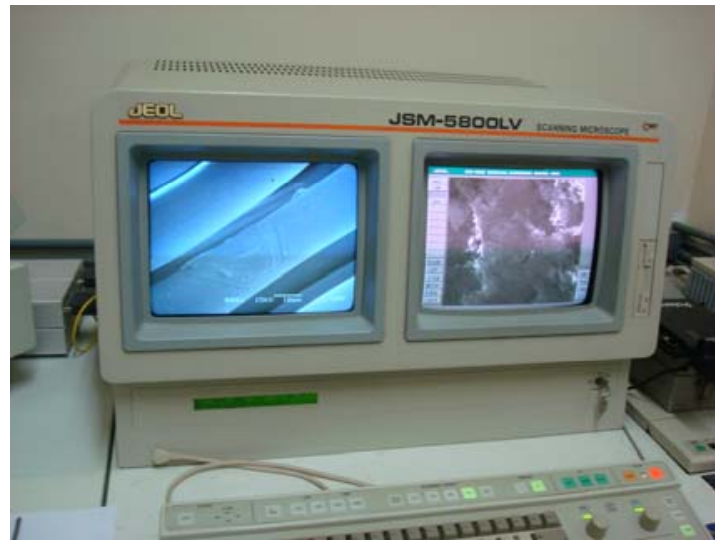

FIGURA 76. Detalhe da fibra de náilon 


\subsubsection{Ensaios de adesão interfacial}

O termo adesão é usado para descrever as forças atômicas, fundamentais e moleculares, responsáveis pela fixação de duas faces conjuntas e como grandeza responsável pela resistência à abertura entre estas faces medida por ensaios destrutivos (Packham, 2005).

O efeito da temperatura na interação interfacial e determinação de quantidades de ligações estáveis e instáveis foi examinado na interface do náilon 6 , náilon 6.6 e do poliéster com composto de borracha natural/SBR, e em todos os sistemas do tipo fibra-borracha, com o aumento da temperatura de ensaio, ocorreu redução na resistência à adesão. Isto é especialmente atribuído ao rompimento de bandas de hidrogênio e interações London (Jamshidi et al., 2004). Com base no exposto pode-se dizer que os resultados de adesão são afetados pelas etapas de processamento das fibras em que existe exposição à temperatura. Na Figura 77 é mostrado, de forma esquemática, como foi realizado o ensaio de adesão entre a cobertura de borracha e o $1^{\circ}$ tecido de uma correia transportadora.

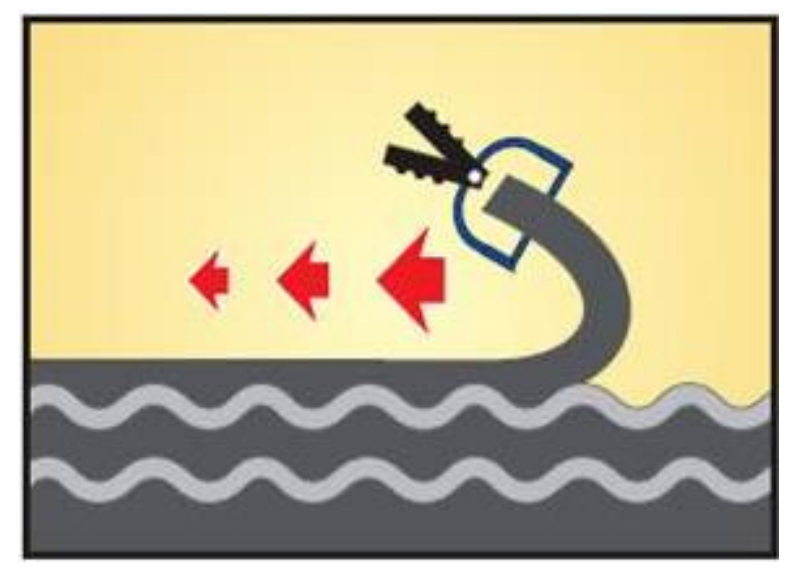

FIGURA 77. Ensaio de adesão entre a cobertura e o $1^{\circ}$ tecido 


\subsubsection{Desenvolvimento teórico}

O desenvolvimento teórico foi feito com o objetivo de encontrar a força máxima e a tenacidade da fibra utilizando métodos de cálculo tradicionais por resistência de materiais, decomposição das forças por geometria básica e comparação com resultados experimentais. A análise dos resultados teóricos e experimentais foi realizada com o objetivo de encontrar os desvios entre ambos.

Para o cálculo da resistência e tenacidade das fibras foram consideradas as principais propriedades mecânicas inerentes a uma fibra, tais como o título, peso específico, diâmetro da fibra, diâmetro do filamento e tensão admissível do material. Para o diâmetro da fibra foi considerado o cálculo da área média dos filamentos. Para obtenção do diâmetro de cada filamento foi adotada uma metodologia diferente da utilizada e encontrada na literatura, em geral utiliza-se a microscopia. Neste caso utilizou-se a propriedade de peso da fibra pelo seu título.

O peso em gramas por metro de uma fibra (P1) foi calculado mediante equação 1:

$$
\mathrm{P} 1=\frac{\text { Título }}{\text { tex }} \text { (grama) }
$$

tex $=$ peso da fibra em 1000 metros de comprimento

O peso em gramas por metro de um filamento (P2) é expresso como:

$$
P 2=\underline{P 1}
$$

$\mathrm{n}=$ número de filamentos

\section{n}

A área circular do filamento (Ac) é calculada conforme a equação 3 sendo:

$$
A c=\underline{\pi x d^{2}}
$$

d = diâmetro do filamento

O volume do filamento $(\mathrm{V})$ foi obtido multiplicando-se a área $(\mathrm{Ac})$ pelo comprimento do filamento sendo:

$$
V=A c \times I
$$


I = comprimento do filamento

Logo, o cálculo teórico do peso do filamento é expresso como:

$\rho=$ peso específico do material

$$
\mathrm{P} 2=\mathrm{V} \times \rho
$$

Em que substituindo as equações 3 e 4 em 5 tem-se a equação 6 sendo:

$$
P 2=\underline{\pi d^{2}} \times \mid x \rho
$$

4

Logo, se isolarmos o d tem-se a equação 7 conforme abaixo:

$$
d=\sqrt{\frac{P 2 \times 4}{\pi \times 1 \times \rho}}
$$

$O$ cálculo da força é expresso como $F=\sigma \times A c$

$\sigma=$ tensão admissível do material

Substituindo a equação 3 em 8 tem-se a expressão 9 que define a força teórica:

$$
F_{\text {teo }}=\sigma \times \Pi x d^{2}
$$

4

Para calcular o diâmetro médio $\left(D_{m}\right)$ da fibra, foi adotado um conjunto de 24 filamentos, perfeitamente circulares, no qual pode-se utilizar 0 melhor aproveitamento da área total da circunferência pelo cálculo da área do quadrado para cada um dos filamentos.
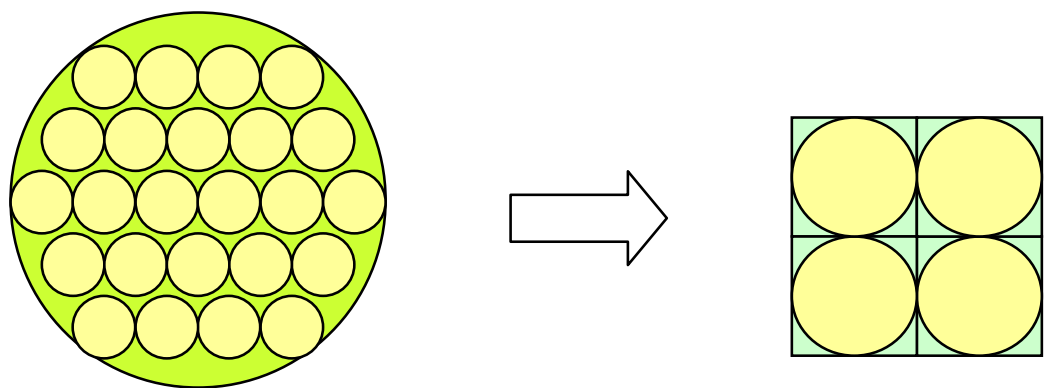

Neste caso sendo a área do quadrado $=d^{2}$ tem-se que a área média $\left(A_{m}\right)=d^{2} \times n$ em que:

$$
D_{m}=\sqrt{\frac{A_{m} \times 4}{\pi}}
$$

O cálculo da tenacidade da fibra é dado pela equação 11:

$$
\begin{array}{ll}
T=\frac{F}{\text { tex }} & (\mathrm{cN})
\end{array}
$$




\section{RESULTADOS E DISCUSSÃO}

Inicialmente foi realizada a análise das propriedades físicas das fibras e tecidos de náilon e poliéster na etapa inicial de fabricação, ensaios de tração das fibras em amostras extraídas após cada uma das etapas de fabricação e ensaios de tração monitorada para avaliar o mecanismo de fratura destes materiais. As análises por MEV foram realizadas em amostras extraídas após cada uma das etapas de fabricação. Nas Tabelas 3 a 6 são apresentados os resultados das propriedades físicas das fibras e tecidos indicando as normas utilizadas para os ensaios.

TABELA 3. Propriedades físicas da fibra de náilon 6.6

\begin{tabular}{lcc}
\hline & FIBRA DE NÁILON & \\
\hline \multicolumn{1}{c}{ ENSAIO } & RESULTADO & NORMA \\
Título (dtex) (1) & 2100 & ABNT NBR 13214 \\
Carga de Ruptura (N) & 169 & ASTM D-885 \\
Alongamento à Ruptura (\%) & 20 & ASTM D-885 \\
Tenacidade (cN/tex) (3) & 80,5 & ABNT NBR 13214 \\
Encolhimento (\%) (2) & 5,5 & ABNT NBR 13215 \\
Número de Filamentos & 280 & FORNECEDOR \\
Torção (voltas por polegada) & 2,5 & PROJETO \\
Diâmetro estimado (mm) & 0,55 & Item 3.2.5 \\
Ruptura estimada do filamento (N) & 0,65 & Item 3.2.5 \\
\hline
\end{tabular}

TABELA 4. Propriedades físicas do tecido de náilon 6.6

\begin{tabular}{lcc}
\hline & TECIDO DE NÁILON & \\
\hline \multicolumn{1}{c}{ ENSAIO } & RESULTADO & NORMA \\
Espessura $(\mathrm{mm})$ & 1,1 & ABNT NBR 13383 \\
Peso específico $\left(\mathrm{kg} / \mathrm{m}^{2}\right)$ & 0,565 & ABNT NBR 10591 \\
Contagem das fibras & 47 & ABNT NBR 10588 \\
Tensão de ruptura $(\mathrm{kN} / \mathrm{m})$ & 237 & ABNT NBR 11912 \\
Alongamento à ruptura $(\%)$ & 18 & ABNT NBR 11912 \\
\hline
\end{tabular}


TABELA 5. Propriedades físicas da fibra de poliéster

\begin{tabular}{lcc}
\hline & FIBRA DE POLIÉSTER & \\
\hline \multicolumn{1}{c}{ ENSAIO } & RESULTADO & NORMA \\
Título (dtex) (1) & 1100 & ABNT NBR 13214 \\
Carga de Ruptura (N) & 84,5 & ASTM D-885 \\
Alongamento à Ruptura (\%) & 15 & ASTM D-885 \\
Tenacidade (cN/tex) (3) & 76,8 & ABNT NBR 13214 \\
Encolhimento (\%) (2) & 3 & ABNT NBR 13215 \\
Número de Filamentos & 210 & FORNECEDOR \\
Torção (voltas por polegada) & 2,5 & PROJETO \\
Diâmetro estimado (mm) & 0,4 & Item 3.2.5 \\
Ruptura estimada do filamento (N) & 0,45 & Item 3.2.5 \\
\hline
\end{tabular}

TABELA 6. Propriedades físicas do tecido de poliéster

\begin{tabular}{lcc}
\hline & TECIDO DE POLIÉSTER & \\
\hline \multicolumn{1}{c}{ ENSAIO } & RESULTADO & NORMA \\
Espessura $(\mathrm{mm})$ & 0,8 & ABNT NBR 13383 \\
Peso específico $\left(\mathrm{kg} / \mathrm{m}^{2}\right)$ & 0,410 & ABNT NBR 10591 \\
Contagem das fibras & 58 & ABNT NBR 10588 \\
Tensão de ruptura $(\mathrm{kN} / \mathrm{m})$ & 125 & ABNT NBR 11912 \\
Alongamento à ruptura $(\%)$ & 12 & ABNT NBR 11912 \\
\hline
\end{tabular}

(1) O título em dtex de uma fibra é o peso em gramas dividido por 10.000 metros desta fibra.

(2) $\mathrm{O}$ encolhimento foi realizado com a temperatura de $180^{\circ} \mathrm{C}$, tempo de exposição de 2 minutos e tensão aplicada na fibra de 55 gramas.

(3) A tenacidade de uma fibra é a proporção da sua carga de ruptura em cN pela sua massa linear, neste caso tex expresso em gramas de 1.000 metros de fibra. 


\subsection{Fibras e tecidos}

Inicialmente, utilizando o desenvolvimento teórico do item 3.2.6, foi calculada a força máxima da fibra na sua etapa inicial de fabricação e comparada aos resultados experimentais. Na sequência foram ensaiadas à tração as fibras têxteis dos tipos singelas, torcidas, construídas, dipadas e vulcanizadas para levantamento do desvio após cada etapa de processamento. Ensaios de tração monitorados para algumas das etapas de processamento foram realizados para visualização da sequência de fratura para estas fibras. Estes ensaios colaboraram para o entendimento do comportamento das fibras submetidas a tensões multiaxiais durante as etapas de processamento do produto.

Seguindo a mesma linha, foram realizadas análises por microscopia eletrônica de varredura considerando amostras das fibras têxteis dos tipos singelas, torcidas, construídas, dipadas e vulcanizadas. Estas análises colaboraram para o entendimento do aspecto das faces de fratura das fibras submetidas às tensões multiaxiais durante as etapas de processamento do produto.

\subsubsection{Cálculo da força de ruptura "teórica versus experimental"}

Os cálculos foram realizados com base no desenvolvimento teórico do item 3.2.6 somente para as fibras singelas. Os resultados das fibras das demais etapas de processamento foram utilizados para comparação e obtenção dos desvios. Nas Tabelas 7 a 10 são apresentados os resultados experimentais versus o cálculo teórico da força de ruptura para as amostras A, B e C. As últimas linhas em negrito são a média de todos os resultados. 
TABELA 7. Força de ruptura teórica versus experimental para a amostra de náilon "A"

\begin{tabular}{|c|c|c|c|c|c|c|c|c|c|c|c|c|}
\hline $\begin{array}{l}\text { Titulo } \\
\text { (dtex) }\end{array}$ & $\begin{array}{c}P 1 \\
(g / m)\end{array}$ & $n$ & $\begin{array}{c}P 2 \\
(g / m)\end{array}$ & $\underset{\left(g / m^{3}\right)}{\rho}$ & $\underset{(m m)}{d}$ & $\begin{array}{c}D m \\
(m m)\end{array}$ & $\underset{\left(N / \mathbf{m m}^{2}\right)}{\boldsymbol{\sigma}}$ & $\underset{\left(m m^{2}\right)}{A}$ & $\begin{array}{c}F \text { teo } \\
(N)\end{array}$ & $\begin{array}{l}F \exp \\
(N)\end{array}$ & $\begin{array}{c}\text { Desvio } \\
(\%)\end{array}$ & $\begin{array}{c}T \\
(c N / t e x)\end{array}$ \\
\hline 2137 & 0,2137 & 280 & 0,00076 & 1140000 & 0,029 & 0,551 & 950 & 0,00067 & 178,08 & 175,51 & 1,46 & 82,13 \\
\hline 2138 & 0,2138 & 280 & 0,00076 & 1140000 & 0,029 & 0,551 & 950 & 0,00067 & 178,17 & 175,16 & 1,72 & 81,93 \\
\hline 2137 & 0,2137 & 280 & 0,00076 & 1140000 & 0,029 & 0,551 & 950 & 0,00067 & 178,08 & 174,89 & 1,83 & 81,84 \\
\hline 2136 & 0,2136 & 280 & 0,00076 & 1140000 & 0,029 & 0,551 & 950 & 0,00067 & 178,00 & 173,42 & 2,64 & 81,19 \\
\hline 2134 & 0,2134 & 280 & 0,00076 & 1140000 & 0,029 & 0,551 & 950 & 0,00067 & 177,83 & 172,53 & 3,07 & 80,85 \\
\hline 2135 & 0,2135 & 280 & 0,00076 & 1140000 & 0,029 & 0,551 & 950 & 0,00067 & 177,92 & 175,56 & 1,34 & 82,23 \\
\hline 2135 & 0,2135 & 280 & 0,00076 & 1140000 & 0,029 & 0,551 & 950 & 0,00067 & 177,92 & 174,67 & 1,86 & 81,81 \\
\hline 2132 & 0,2132 & 280 & 0,00076 & 1140000 & 0,029 & 0,551 & 950 & 0,00067 & 177,67 & 172,89 & 2,76 & 81,09 \\
\hline 2133 & 0,2133 & 280 & 0,00076 & 1140000 & 0,029 & 0,551 & 950 & 0,00067 & 177,75 & 174,44 & 1,89 & 81,78 \\
\hline 2135 & 0,2135 & 280 & 0,00076 & 1140000 & 0,029 & 0,551 & 950 & 0,00067 & 177,92 & 175,38 & 1,45 & 82,14 \\
\hline 2135 & 0,2135 & 280 & 0,00076 & 1140000 & 0,029 & 0,551 & 950 & 0,00067 & 177,93 & 174,44 & 2,00 & 81,70 \\
\hline
\end{tabular}

TABELA 8. Força de ruptura teórica versus experimental para a amostra de náilon "B"

\begin{tabular}{|c|c|c|c|c|c|c|c|c|c|c|c|c|}
\hline $\begin{array}{l}\text { Titulo } \\
\text { (dtex) }\end{array}$ & $\begin{array}{c}P 1 \\
(g / m)\end{array}$ & $n$ & $\begin{array}{c}P 2 \\
(g / m)\end{array}$ & $\underset{\left(g / m^{3}\right)}{\rho}$ & $\underset{(m m)}{d}$ & $\begin{array}{c}D m \\
(\mathrm{~mm})\end{array}$ & $\underset{\left(\mathrm{N} / \mathbf{m m}^{2}\right)}{\boldsymbol{\sigma}}$ & $\underset{\left(m m^{2}\right)}{A}$ & $\begin{array}{l}\text { F teo } \\
(N)\end{array}$ & $\begin{array}{l}F \exp \\
(N)\end{array}$ & $\begin{array}{c}\text { Desvio } \\
\text { (\%) }\end{array}$ & $\begin{array}{c}T \\
\text { (cN/tex) }\end{array}$ \\
\hline 2122 & 0,2122 & 280 & 0,00076 & 1140000 & 0,029 & 0,549 & 950 & 0,00066 & 176,83 & 174,89 & 1,11 & 82,42 \\
\hline 2123 & 0,2123 & 280 & 0,00076 & 1140000 & 0,029 & 0,549 & 950 & 0,00067 & 176,92 & 172,00 & 2,86 & 81,02 \\
\hline 2125 & 0,2125 & 280 & 0,00076 & 1140000 & 0,029 & 0,550 & 950 & 0,00067 & 177,08 & 172,00 & 2,96 & 80,94 \\
\hline 2124 & 0,2124 & 280 & 0,00076 & 1140000 & 0,029 & 0,550 & 950 & 0,00067 & 177,00 & 174,89 & 1,21 & 82,34 \\
\hline 2122 & 0,2122 & 280 & 0,00076 & 1140000 & 0,029 & 0,549 & 950 & 0,00066 & 176,83 & 170,75 & 3,56 & 80,47 \\
\hline 2127 & 0,2127 & 280 & 0,00076 & 1140000 & 0,029 & 0,550 & 950 & 0,00067 & 177,25 & 173,20 & 2,34 & 81,43 \\
\hline 2123 & 0,2123 & 280 & 0,00076 & 1140000 & 0,029 & 0,549 & 950 & 0,00067 & 176,92 & 171,37 & 3,23 & 80,72 \\
\hline 2124 & 0,2124 & 280 & 0,00076 & 1140000 & 0,029 & 0,550 & 950 & 0,00067 & 177,00 & 174,40 & 1,49 & 82,11 \\
\hline 2125 & 0,2125 & 280 & 0,00076 & 1140000 & 0,029 & 0,550 & 950 & 0,00067 & 177,08 & 172,53 & 2,64 & 81,19 \\
\hline 2126 & 0,2126 & 280 & 0,00076 & 1140000 & 0,029 & 0,550 & 950 & 0,00067 & 177,17 & 172,93 & 2,45 & 81,34 \\
\hline 2124 & 0,2124 & 280 & 0,00076 & 1140000 & 0,029 & 0,550 & 950 & 0,00067 & 177,01 & 172,90 & 2,38 & 81,40 \\
\hline
\end{tabular}


TABELA 9. Força de ruptura teórica versus experimental para a amostra de poliéster "C"

\begin{tabular}{|c|c|c|c|c|c|c|c|c|c|c|c|c|}
\hline $\begin{array}{l}\text { Titulo } \\
\text { (dtex) }\end{array}$ & $\begin{array}{c}P 1 \\
(g / m)\end{array}$ & $n$ & $\begin{array}{c}P 2 \\
(g / m)\end{array}$ & $\underset{\left(g / m^{3}\right)}{\rho}$ & $\underset{(m m)}{d}$ & $\begin{array}{c}D m \\
(m m)\end{array}$ & $\underset{\left(N / m^{2}\right)}{\sigma}$ & $\underset{\left(m m^{2}\right)}{A}$ & $\begin{array}{c}F \text { teo } \\
(N)\end{array}$ & $\begin{array}{l}F \exp \\
(N)\end{array}$ & $\begin{array}{c}\text { Desvio } \\
(\%)\end{array}$ & $\begin{array}{c}T \\
\text { (cN/tex) }\end{array}$ \\
\hline 1142 & 0,1142 & 210 & 0,00054 & 1380000 & 0,022 & 0,366 & 1100 & 0,00039 & 91,03 & 85,69 & 6,23 & 75,03 \\
\hline 1145 & 0,1145 & 210 & 0,00055 & 1380000 & 0,022 & 0,367 & 1100 & 0,00040 & 91,27 & 86,53 & 5,47 & 75,57 \\
\hline 1148 & 0,1148 & 210 & 0,00055 & 1380000 & 0,022 & 0,367 & 1100 & 0,00040 & 91,51 & 84,80 & 7,91 & 73,87 \\
\hline 1145 & 0,1145 & 210 & 0,00055 & 1380000 & 0,022 & 0,367 & 1100 & 0,00040 & 91,27 & 83,82 & 8,89 & 73,20 \\
\hline 1143 & 0,1143 & 210 & 0,00054 & 1380000 & 0,022 & 0,366 & 1100 & 0,00039 & 91,11 & 85,06 & 7,11 & 74,42 \\
\hline 1145 & 0,1145 & 210 & 0,00055 & 1380000 & 0,022 & 0,367 & 1100 & 0,00040 & 91,27 & 85,51 & 6,73 & 74,68 \\
\hline 1143 & 0,1143 & 210 & 0,00054 & 1380000 & 0,022 & 0,366 & 1100 & 0,00039 & 91,11 & 86,04 & 5,89 & 75,28 \\
\hline 1146 & 0,1146 & 210 & 0,00055 & 1380000 & 0,022 & 0,367 & 1100 & 0,00040 & 91,35 & 85,78 & 6,50 & 74,85 \\
\hline 1145 & 0,1145 & 210 & 0,00055 & 1380000 & 0,022 & 0,367 & 1100 & 0,00040 & 91,27 & 87,11 & 4,77 & 76,08 \\
\hline 1145 & 0,1145 & 210 & 0,00055 & 1380000 & 0,022 & 0,367 & 1100 & 0,00040 & 91,27 & 88,71 & 2,88 & 77,48 \\
\hline 1145 & 0,1145 & 210 & 0,00055 & 1380000 & 0,022 & 0,367 & 1100 & 0,00039 & 91,24 & 85,91 & 6,24 & 75,05 \\
\hline
\end{tabular}

TABELA 10. Força de ruptura teórica versus experimental para a amostra de poliéster "D"

\begin{tabular}{|c|c|c|c|c|c|c|c|c|c|c|c|c|}
\hline $\begin{array}{l}\text { Titulo } \\
\text { (dtex) }\end{array}$ & $\begin{array}{c}P 1 \\
(g / m)\end{array}$ & $n$ & $\begin{array}{c}P 2 \\
(g / m)\end{array}$ & $\underset{\left(g / m^{3}\right)}{\rho}$ & $\underset{(m m)}{d}$ & $\begin{array}{c}D m \\
(\mathrm{~mm})\end{array}$ & $\underset{\left(N / \mathbf{m m}^{2}\right)}{\boldsymbol{\sigma}}$ & $\begin{array}{c}A \\
\left(m m^{2}\right)\end{array}$ & $\begin{array}{c}F \text { teo } \\
(N)\end{array}$ & $\begin{array}{c}F \exp \\
(N)\end{array}$ & $\begin{array}{c}\text { Desvio } \\
(\%)\end{array}$ & $\begin{array}{c}T \\
(c N / t e x)\end{array}$ \\
\hline 1139 & 0,1139 & 210 & 0,00054 & 1380000 & 0,022 & 0,366 & 1100 & 0,00039 & 90,79 & 88,27 & 5,95 & 77,50 \\
\hline 1141 & 0,1141 & 210 & 0,00054 & 1380000 & 0,022 & 0,366 & 1100 & 0,00039 & 90,95 & 88,62 & 5,10 & 77,67 \\
\hline 1142 & 0,1142 & 210 & 0,00054 & 1380000 & 0,022 & 0,366 & 1100 & 0,00039 & 91,03 & 84,44 & 7,35 & 73,94 \\
\hline 1145 & 0,1145 & 210 & 0,00055 & 1380000 & 0,022 & 0,367 & 1100 & 0,00040 & 91,27 & 83,15 & 8,89 & 72,62 \\
\hline 1140 & 0,1140 & 210 & 0,00054 & 1380000 & 0,022 & 0,366 & 1100 & 0,00039 & 90,87 & 86,93 & 6,82 & 76,26 \\
\hline 1143 & 0,1143 & 210 & 0,00054 & 1380000 & 0,022 & 0,366 & 1100 & 0,00039 & 91,11 & 87,82 & 6,55 & 76,84 \\
\hline 1140 & 0,1140 & 210 & 0,00054 & 1380000 & 0,022 & 0,366 & 1100 & 0,00039 & 90,87 & 88,40 & 5,61 & 77,54 \\
\hline 1141 & 0,1141 & 210 & 0,00054 & 1380000 & 0,022 & 0,366 & 1100 & 0,00039 & 90,95 & 86,31 & 6,03 & 75,64 \\
\hline 1143 & 0,1143 & 210 & 0,00054 & 1380000 & 0,022 & 0,366 & 1100 & 0,00039 & 91,11 & 84,04 & 4,59 & 73,53 \\
\hline 1144 & 0,1144 & 210 & 0,00054 & 1380000 & 0,022 & 0,367 & 1100 & 0,00039 & 91,19 & 87,87 & 2,79 & 76,81 \\
\hline 1142 & 0,1142 & 210 & 0,00054 & 1380000 & 0,022 & 0,366 & 1100 & 0,00039 & 91,01 & 86,59 & 5,97 & 75,83 \\
\hline
\end{tabular}

O desvio encontrado para as fibras de náilon foi em média 2,19\% e para as fibras de poliéster foi em média $6,1 \%$, sendo maior para as fibras de poliéster, em torno de $+3,91 \%$. Isto se explica pela maior variação nas propriedades medidas para esta fibra. Observa-se também uma pequena diferença entre a média dos valores de tenacidade encontrados, se comparados aos valores de tenacidade apresentados nas Tabelas $3(80,5)$ e $5(76,8)$, sendo $+1,3 \%$ para o náilon e - 1,8\% para o poliéster. 
Os resultados das fibras das demais etapas de processamento foram utilizados para comparação e obtenção dos desvios. Nas Tabelas 11 a 14 são apresentados os resultados comparativos e desvios entre as etapas de processamento das amostras A, B e C. As penúltimas linhas em negrito são as médias de todos os resultados e os desvios padrão nas últimas linhas em negrito foram calculados utilizando sempre como base as médias dos resultados de ruptura e alongamento da fibra singela.

TABELA 11. Resultados de ruptura, alongamento e desvios para a amostra de náilon "A"

\begin{tabular}{|c|c|c|c|c|c|c|c|c|c|}
\hline \multicolumn{2}{|c|}{ SINGELO } & \multicolumn{2}{|c|}{ TORCIDO } & \multicolumn{2}{|c|}{ CONSTRUÍDO } & \multicolumn{2}{|c|}{ DIPADO } & \multicolumn{2}{|c|}{ VULCANIZADO } \\
\hline $\begin{array}{c}R U P . \\
(N)\end{array}$ & $\begin{array}{c}\text { ALONG. } \\
\%\end{array}$ & $\begin{array}{c}R U P . \\
(N)\end{array}$ & $\begin{array}{c}\text { ALONG. } \\
\%\end{array}$ & $\begin{array}{c}R U P . \\
(N)\end{array}$ & $\begin{array}{c}\text { ALONG. } \\
\%\end{array}$ & $\begin{array}{c}R U P . \\
(N)\end{array}$ & $\begin{array}{c}\text { ALONG. } \\
\%\end{array}$ & $\begin{array}{l}R U P . \\
(N)\end{array}$ & $\begin{array}{c}\text { ALONG. } \\
\%\end{array}$ \\
\hline 175,51 & 19,67 & 175,16 & 18,54 & 146,68 & 18,33 & 156,87 & 21,52 & 159,54 & 14,07 \\
\hline 175,16 & 19,43 & 176,62 & 18,64 & 161,76 & 19,40 & 160,03 & 23,01 & 156,07 & 14,40 \\
\hline 174,89 & 19,70 & 175,91 & 17,73 & 164,70 & 20,24 & 157,63 & 23,15 & 156,07 & 14,45 \\
\hline 173,42 & 20,69 & 181,25 & 19,14 & 157,63 & 18,05 & 152,73 & 22,07 & 157,81 & 14,68 \\
\hline 172,53 & 18,43 & 176,89 & 19,04 & 163,23 & 19,39 & 155,40 & 22,32 & 159,54 & 14,93 \\
\hline 175,56 & 20,07 & 179,07 & 20,11 & 166,66 & 20,56 & 158,34 & 22,97 & 147,44 & 14,87 \\
\hline 174,67 & 19,92 & 178,32 & 20,03 & 166,88 & 18,63 & 159,54 & 21,97 & 157,81 & 15,93 \\
\hline 172,89 & 19,58 & 179,78 & 19,36 & 162,74 & 18,27 & 155,40 & 22,94 & 161,28 & 15,75 \\
\hline 174,44 & 20,33 & 183,70 & 20,52 & 162,48 & 17,05 & 158,83 & 21,12 & 154,34 & 15,13 \\
\hline 175,38 & 19,53 & 181,03 & 20,42 & 163,94 & 18,88 & 149,09 & 20,33 & 157,81 & 15,64 \\
\hline 174,44 & 19,74 & 178,77 & 19,35 & 161,67 & 18,88 & 156,39 & 22,14 & 156,77 & 14,99 \\
\hline DESVIO & PADRÃO & 2,48 & $-1,94$ & $-7,32$ & $-4,33$ & $-10,35$ & 12,19 & $-10,13$ & $-24,07$ \\
\hline
\end{tabular}

TABELA 12. Resultados de ruptura, alongamento e desvios para a amostra de náilon "B"

\begin{tabular}{|c|c|c|c|c|c|c|c|c|c|}
\hline \multicolumn{2}{|c|}{ SINGELO } & \multicolumn{2}{|c|}{ TORCIDO } & \multicolumn{2}{|c|}{ CONSTRUÍDO } & \multicolumn{2}{|c|}{ DIPADO } & \multicolumn{2}{|c|}{ VULCANIZADO } \\
\hline $\begin{array}{c}R U P . \\
(N)\end{array}$ & $\begin{array}{c}\text { ALONG. } \\
\%\end{array}$ & $\begin{array}{c}R U P . \\
(N)\end{array}$ & $\begin{array}{c}\text { ALONG. } \\
\%\end{array}$ & $\begin{array}{c}R U P . \\
(N)\end{array}$ & $\begin{array}{c}\text { ALONG. } \\
\%\end{array}$ & $\begin{array}{l}R U P . \\
(N)\end{array}$ & $\begin{array}{c}\text { ALONG. } \\
\%\end{array}$ & $\begin{array}{c}R U P . \\
(N)\end{array}$ & $\begin{array}{c}\text { ALONG. } \\
\%\end{array}$ \\
\hline 174,89 & 19,15 & 175,65 & 16,60 & 160,03 & 18,81 & 150,29 & 19,23 & 152,60 & 18,46 \\
\hline 172,00 & 18,84 & 178,58 & 17,64 & 151,75 & 18,65 & 144,19 & 19,43 & 149,17 & 17,63 \\
\hline 172,00 & 18,39 & 179,03 & 17,49 & 152,51 & 19,33 & 160,79 & 19,08 & 154,34 & 17,13 \\
\hline 174,89 & 19,75 & 179,52 & 17,48 & 155,89 & 19,20 & 144,46 & 19,36 & 147,44 & 17,46 \\
\hline 170,75 & 17,25 & 176,85 & 17,27 & 151,27 & 19,17 & 147,62 & 19,04 & 147,44 & 16,28 \\
\hline 173,20 & 18,23 & 177,34 & 17,43 & 155,18 & 18,44 & 156,65 & 19,59 & 150,86 & 17,21 \\
\hline 171,37 & 17,50 & 176,14 & 17,49 & 144,19 & 16,89 & 153,71 & 21,12 & 154,34 & 18,04 \\
\hline 174,40 & 19,73 & 174,89 & 17,36 & 164,17 & 19,77 & 156,16 & 19,82 & 149,17 & 18,50 \\
\hline 172,53 & 19,42 & 177,34 & 17,82 & 158,12 & 19,23 & 148,37 & 20,31 & 150,86 & 17,16 \\
\hline 172,93 & 18,66 & 168,57 & 15,75 & 162,97 & 19,87 & 160,03 & 19,80 & 156,07 & 18,46 \\
\hline 172,90 & 18,69 & 176,39 & 17,23 & 155,61 & 18,94 & 152,23 & 19,68 & 151,23 & 17,63 \\
\hline DESVIO & PADRÃO & 2,02 & $-7,81$ & $-10,00$ & 1,31 & $-11,96$ & 5,27 & $-12,53$ & $-5,67$ \\
\hline
\end{tabular}


TABELA 13. Resultados de ruptura, alongamento e desvios para a amostra de poliéster "C"

\begin{tabular}{cccccccccc}
\hline \multicolumn{2}{c}{ SINGELO } & \multicolumn{2}{c}{ TORCIDO } & \multicolumn{2}{c}{ CONSTRUÍDO } & \multicolumn{2}{c}{ DIPADO } & \multicolumn{2}{c}{ VULCANIZADO } \\
\hline RUP. & ALONG. & RUP. & ALONG. & RUP. & ALONG. & RUP. & ALONG. & RUP. & ALONG. \\
(N) & $\%$ & (N) & $\%$ & (N) & \% & (N) & \% & (N) & $\%$ \\
\hline 85,69 & 14,40 & 86,44 & 14,74 & 73,99 & 13,71 & 64,73 & 18,56 & 71,09 & 8,12 \\
86,53 & 14,65 & 86,84 & 14,35 & 76,48 & 14,65 & 64,20 & 17,65 & 65,89 & 7,08 \\
84,80 & 15,01 & 86,35 & 14,91 & 72,43 & 14,10 & 62,55 & 17,76 & 57,21 & 8,23 \\
83,82 & 14,98 & 85,69 & 14,78 & 75,32 & 15,25 & 68,07 & 18,50 & 65,89 & 7,60 \\
85,06 & 14,76 & 84,58 & 14,42 & 76,12 & 13,71 & 69,40 & 17,56 & 71,09 & 9,12 \\
85,51 & 15,05 & 86,22 & 14,30 & 74,83 & 15,99 & 66,29 & 17,12 & 90,18 & 8,72 \\
86,04 & 13,87 & 86,35 & 14,55 & 76,43 & 16,16 & 70,20 & 17,23 & 67,62 & 9,93 \\
85,78 & 13,75 & 85,91 & 14,35 & 79,06 & 15,81 & 71,18 & 17,40 & 60,68 & 8,23 \\
87,11 & 14,55 & 86,44 & 14,84 & 79,15 & 15,87 & 71,58 & 17,89 & 62,42 & 7,68 \\
88,71 & 15,66 & 85,69 & 14,50 & 75,23 & 15,62 & 69,40 & 18,64 & 64,15 & 8,86 \\
\hline $\mathbf{8 5 , 9 1}$ & $\mathbf{1 4 , 6 7}$ & $\mathbf{8 6 , 0 5}$ & $\mathbf{1 4 , 5 7}$ & $\mathbf{7 5 , 9 0}$ & $\mathbf{1 5 , 0 9}$ & $\mathbf{6 7 , 7 6}$ & $\mathbf{1 7 , 8 3}$ & $\mathbf{6 7 , 6 2}$ & $\mathbf{8 , 3 6}$ \\
\hline DESVIO PADRÃO & $\mathbf{0 , 1 7}$ & $\mathbf{- 0 , 6 4}$ & $\mathbf{- 1 1 , 6 4}$ & $\mathbf{2 , 8 6}$ & $\mathbf{- 2 1 , 1 2}$ & $\mathbf{2 1 , 5 6}$ & $\mathbf{- 2 1 , 2 8}$ & $\mathbf{- 4 3 , 0 3}$ \\
\hline
\end{tabular}

TABELA 14. Resultados de ruptura, alongamento e desvios para a amostra de poliéster " $D$ "

\begin{tabular}{|c|c|c|c|c|c|c|c|c|c|}
\hline \multicolumn{2}{|c|}{ SINGELO } & \multicolumn{2}{|c|}{ TORCIDO } & \multicolumn{2}{|c|}{ CONSTRUIIDO } & \multicolumn{2}{|c|}{ DIPADO } & \multicolumn{2}{|c|}{ VULCANIZADO } \\
\hline $\begin{array}{l}R U P . \\
(N)\end{array}$ & $\begin{array}{c}\text { ALONG. } \\
\%\end{array}$ & $\begin{array}{l}R U P . \\
(N)\end{array}$ & $\begin{array}{c}\text { ALONG. } \\
\%\end{array}$ & $\begin{array}{l}\text { RUP. } \\
\text { (N) }\end{array}$ & $\begin{array}{c}\text { ALONG. } \\
\%\end{array}$ & $\begin{array}{l}R U P . \\
(N)\end{array}$ & $\begin{array}{c}\text { ALONG. } \\
\%\end{array}$ & $\begin{array}{l}\text { RUP. } \\
\text { (N) }\end{array}$ & $\begin{array}{c}\text { ALONG. } \\
\%\end{array}$ \\
\hline 88,27 & 13,74 & 86,62 & 14,35 & 80,93 & 15,03 & 67,27 & 17,70 & 64,15 & 10,66 \\
\hline 88,62 & 14,49 & 88,00 & 14,85 & 80,13 & 15,98 & 67,71 & 72 & 67,62 & 12,28 \\
\hline 34,44 & 13,93 & 87,56 & 14,89 & 79,99 & 15,43 & 74,39 & 17,71 & 39 & 14,36 \\
\hline 83,15 & 15,67 & 87,56 & 14,62 & 76,83 & 14,20 & 72,87 & 17,37 & 67,62 & 12,89 \\
\hline 86,93 & 15,37 & 85,51 & 14,42 & 76,17 & 15,73 & 70,16 & 17,87 & 58,95 & 11,06 \\
\hline 87,82 & 14,06 & 85,38 & 14,28 & 76,39 & 15,92 & 75,14 & 17,99 & 71,09 & 13,95 \\
\hline 88,40 & 14 & 86,89 & 14 & & & 56 & & & \\
\hline 86,31 & 13,40 & 86,04 & , 15 & 73,90 & 14,30 & 77,10 & 18,54 & 66,33 & 12,82 \\
\hline 84,04 & 15,61 & 87,51 & 15,20 & 75,23 & 13,99 & 78,12 & 18,18 & 65,00 & 15,47 \\
\hline 87,87 & 14,18 & 86,53 & 15,04 & 75,94 & 15,16 & 68,20 & 17,37 & 64,24 & 14,12 \\
\hline 86,59 & 14,51 & 86,76 & 14,67 & 77,26 & 15,14 & 71,75 & 17,68 & 66,18 & 13,21 \\
\hline DESVIC & PADRÃO & 0,20 & 1,10 & $-10,77$ & 4,28 & $-17,13$ & 21,80 & $-23,56$ & $-9,00$ \\
\hline
\end{tabular}

Observou-se grande variação nos desvios encontrados, porém, após a etapa de torção, todas as fibras mostraram redução nas propriedades de resistência a ruptura. Esta redução será mais bem observada a seguir, nos gráficos de tensão de ruptura e alongamento das fibras de náilon e poliéster. 


\subsubsection{Ensaios de tração nas fibras de náilon da amostra da correia "A"}

Nas Figuras 78 e 79 são mostrados os gráficos dos resultados de resistência a tração e alongamento das fibras de náilon durante as etapas de fabricação.

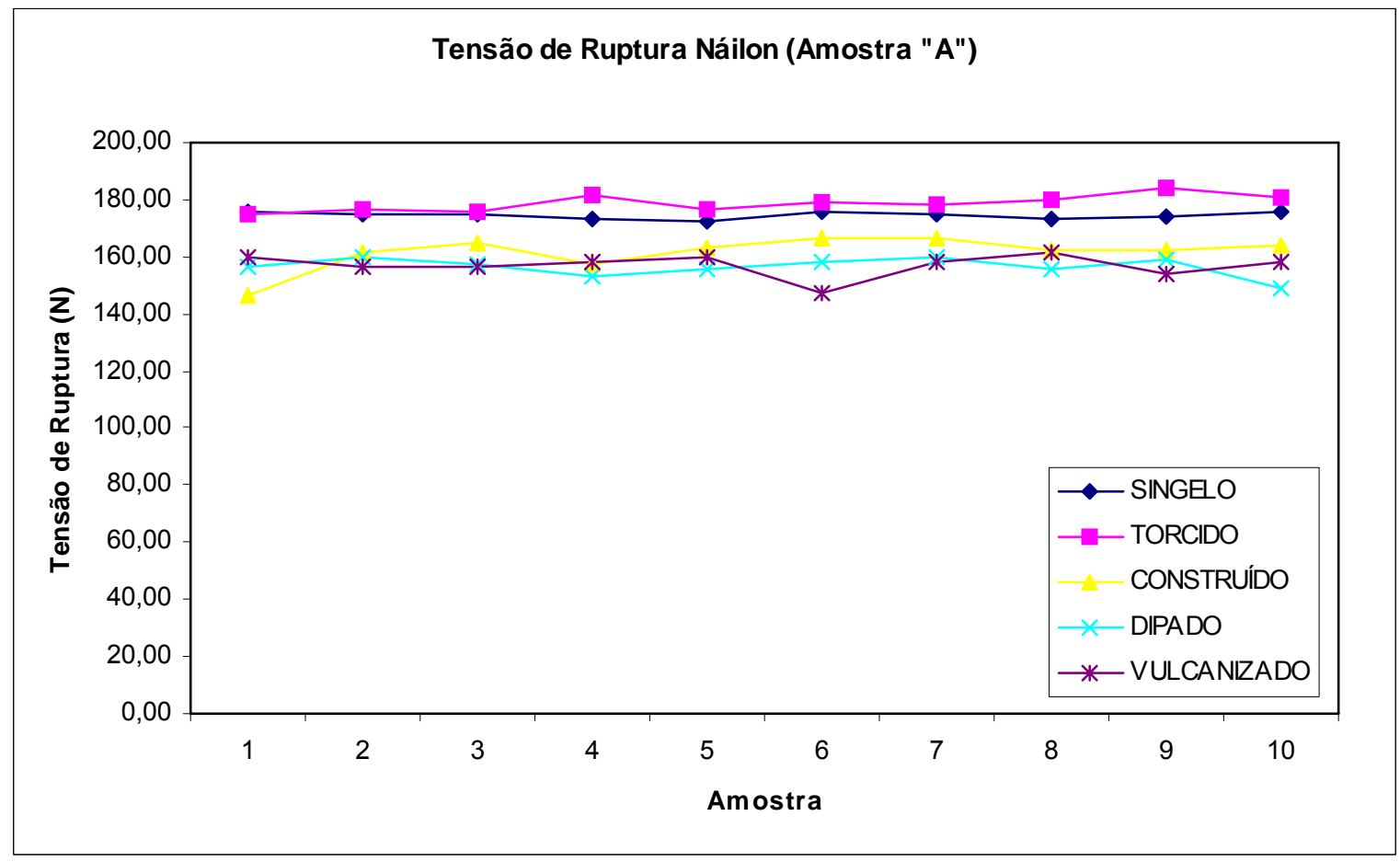

FIGURA 78. Resultados de tensão de ruptura da fibra de náilon (Amostra "A")

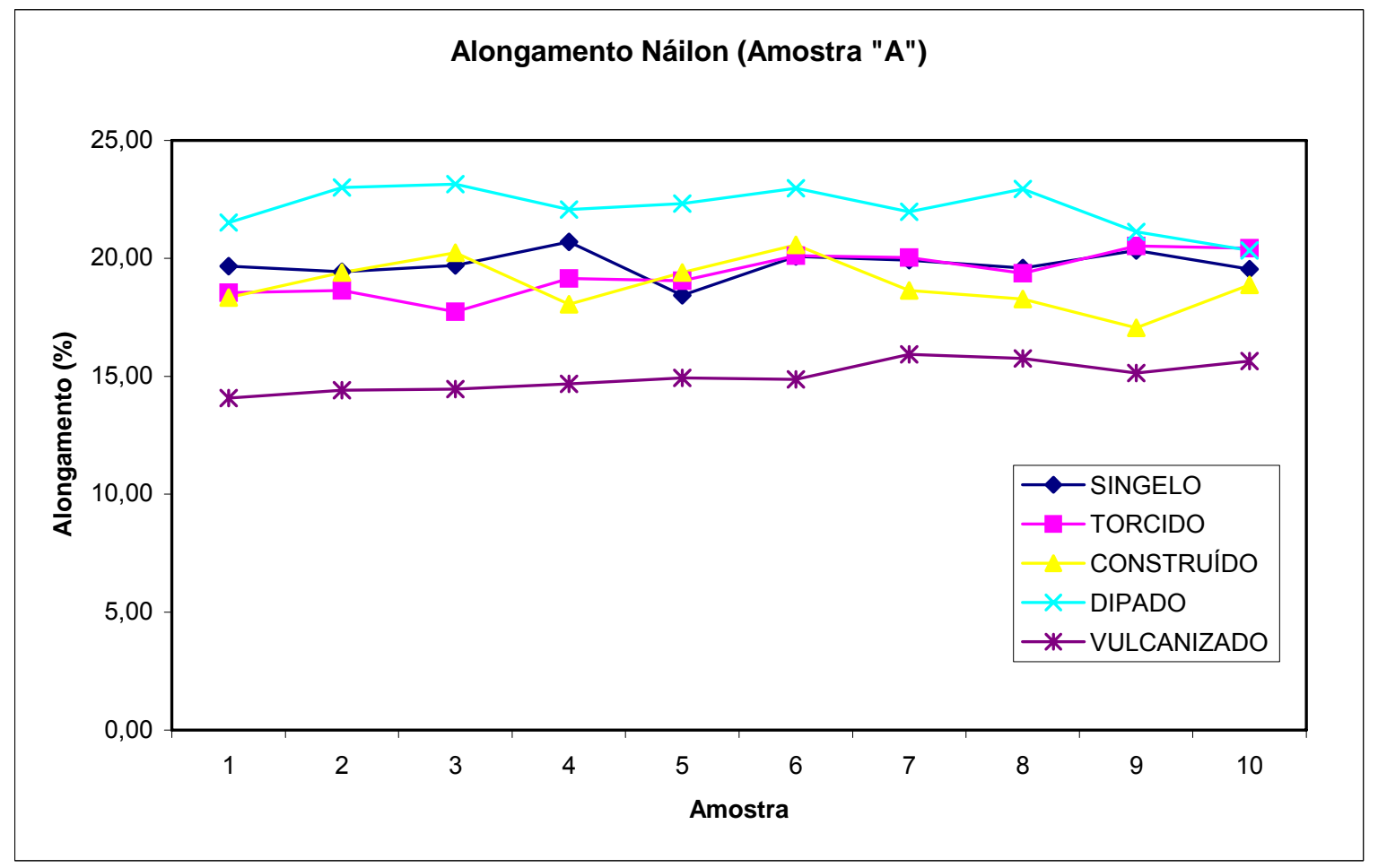

FIGURA 79. Resultados de alongamento da fibra de náilon (Amostra "A") 
Observa-se pelas curvas no gráfico de tensão de ruptura, que houve aumento da resistência mecânica após as etapas de torção da fibra. A partir da etapa de construção do tecido, a fibra apresentou pequena queda na resistência, mantendo-se inferior nas etapas subsequentes. No gráfico de alongamento observa-se também aumento dos resultados para a fibra dipada devido à variação de tensão aplicada no tecido durante a dipagem. Para a fibra vulcanizada ocorreu queda acentuada nos resultados de alongamento, devido ao ocorrido na etapa de dipagem com a variação da tensão aplicada. Vale dizer que esta variação na tensão aplicada na etapa de dipagem é considerada atípica, na qual espera-se que as curvas de dipagem e vulcanização sejam no perfil da amostra B.

\subsubsection{Ensaios de tração nas fibras de náilon da amostra da correia "B"}

Nas Figuras 80 e 81 são mostrados os gráficos dos resultados de resistência a tração e alongamento das fibras de náilon durante as etapas de fabricação.

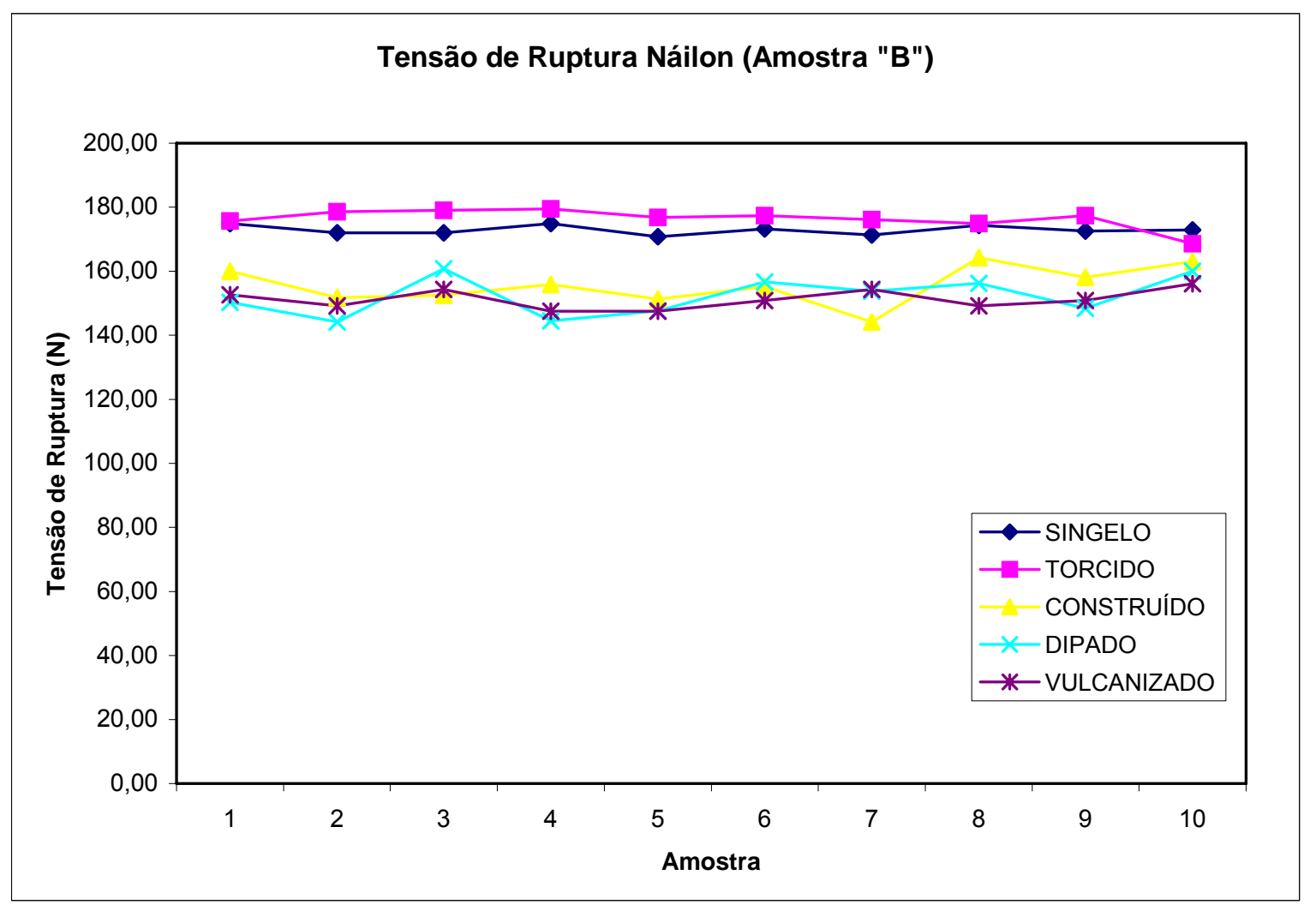

FIGURA 80. Resultados de tensão de ruptura da fibra de náilon (Amostra "B") 


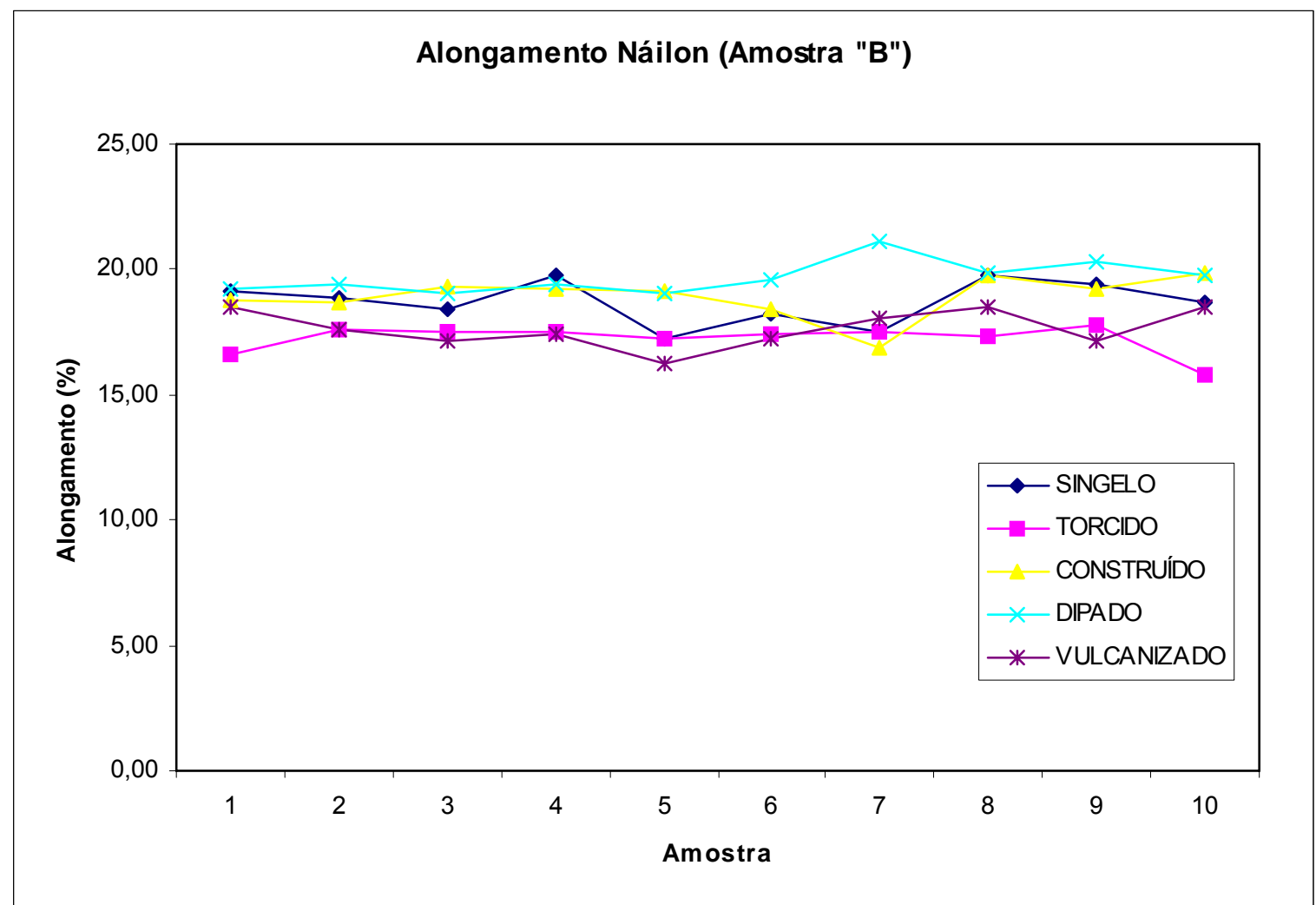

FIGURA 81. Resultados de alongamento da fibra de náilon (Amostra "B")

Os resultados foram similares aos das Figuras 78 e 79, porém, com menor queda na resistência a partir da etapa de construção e mantendo-se estável nas etapas subsequentes. Os resultados de alongamento mantiveram-se estáveis em todas as etapas.

\subsubsection{Ensaios de tração nas fibras de poliéster da amostra da correia " $C$ "}

Nas Figuras 82 e 83 mostram os gráficos dos resultados de resistência a tração e alongamento das fibras de poliéster durante as etapas de fabricação. 


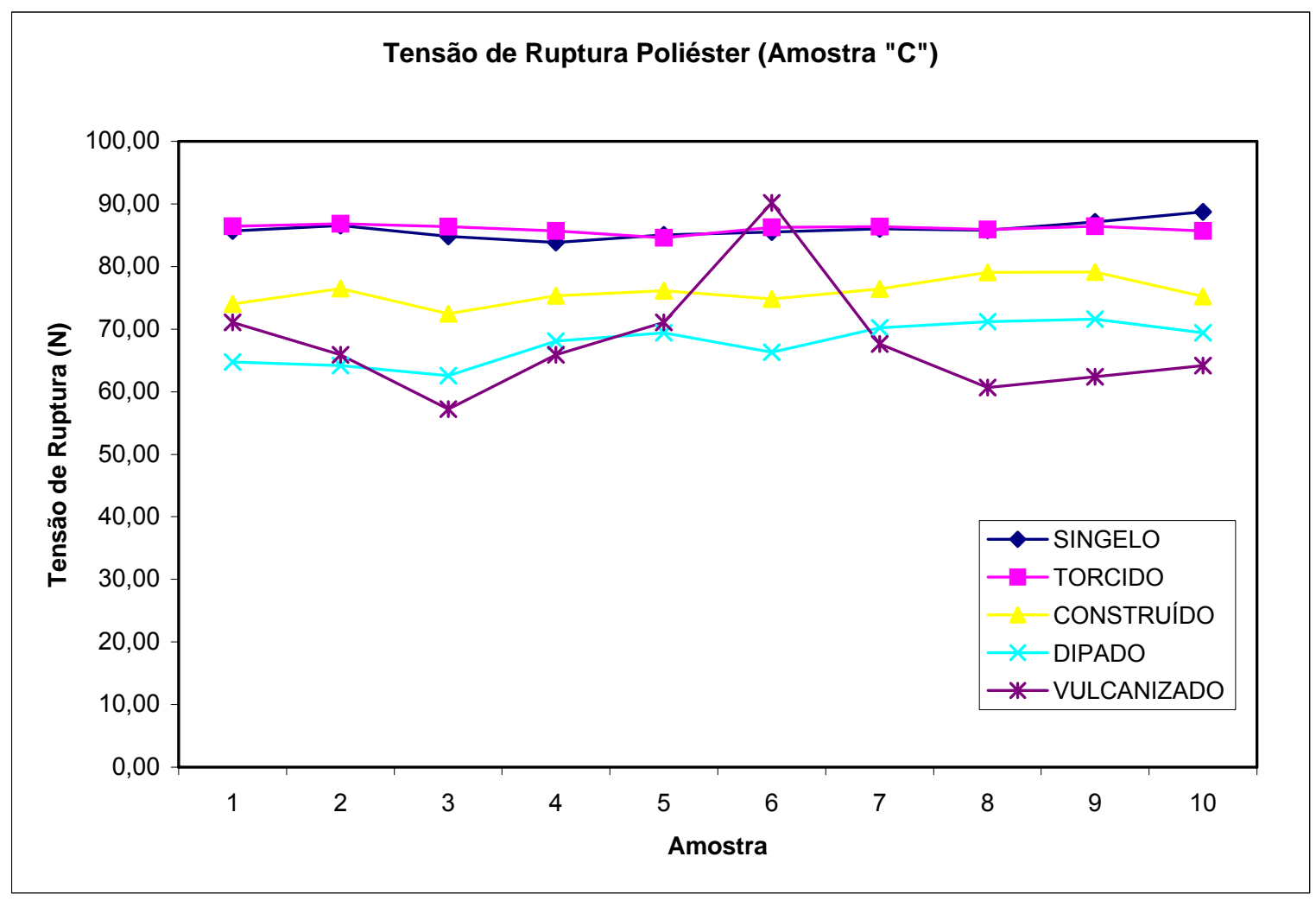

FIGURA 82. Resultados de tensão de ruptura da fibra de poliéster (Amostra "C")

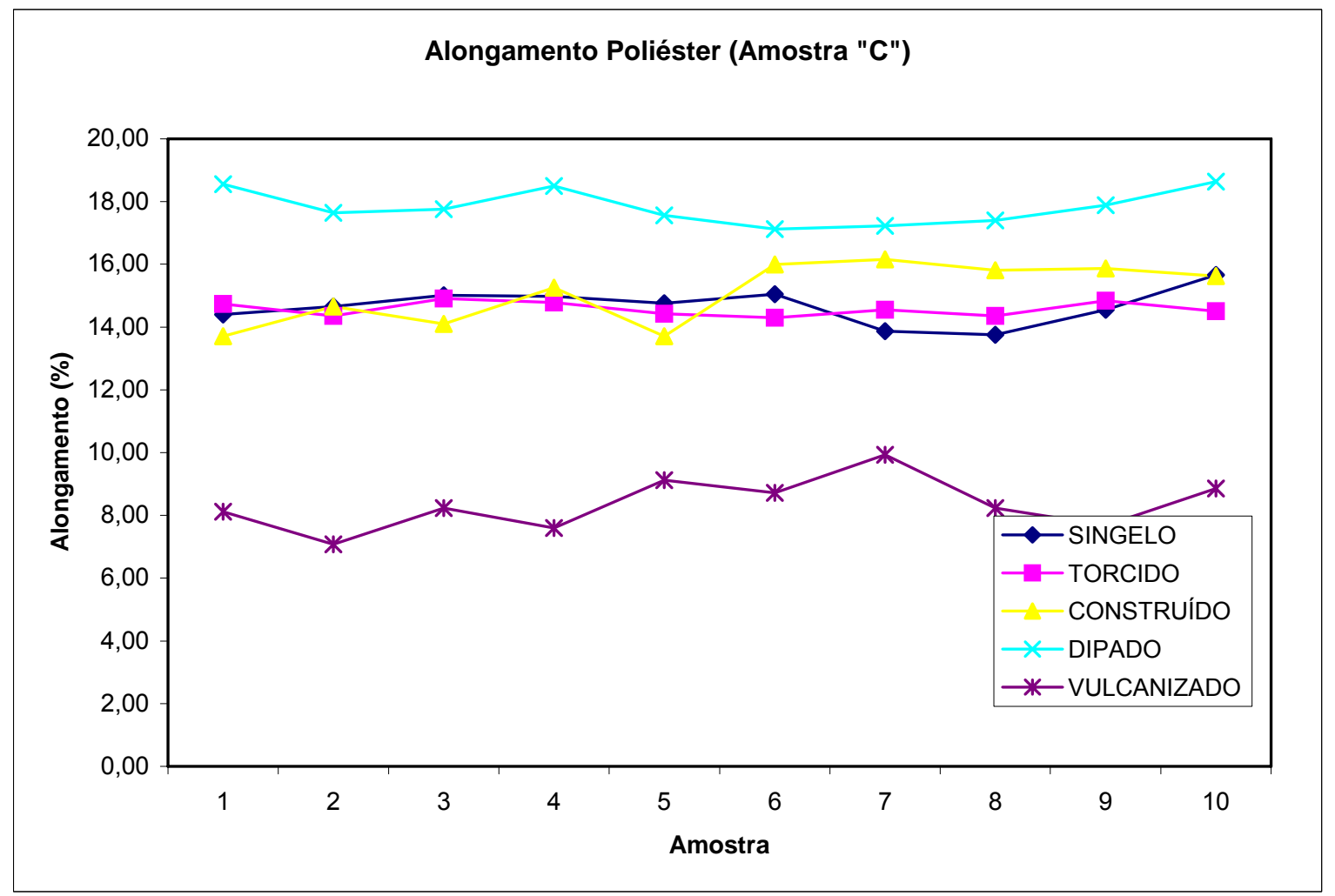

FIGURA 83. Resultados de alongamento da fibra de poliéster (Amostra "C") 
Pelo gráfico de tensão de ruptura, observa-se que os resultados das fibras singelas e torcidas mantiveram-se estáveis, com queda para as demais etapas. Nas curvas de tensão, observa-se um pico elevado na amostra número 6 para a fibra vulcanizada, o qual é considerado atípico, uma vez que normalmente estes resultados não apresentam está variação. Este fato pode ser explicado pela influência de intensa infiltração de borracha na fibra, aumentando assim a coesão entre os filamentos. A infiltração de borracha pode ser visualizada nas Figuras 222 e 224. Ocorreu também aumento nos resultados de alongamento da fibra dipada e queda acentuada após a vulcanização, fato já comentado no item 4.1.2.

\subsubsection{Ensaios de tração nas fibras de poliéster da amostra da correia "D"}

Nas Figuras 84 e 85 são mostrados os gráficos dos resultados de resistência a tração e alongamento das fibras de poliéster durante as etapas de fabricação.

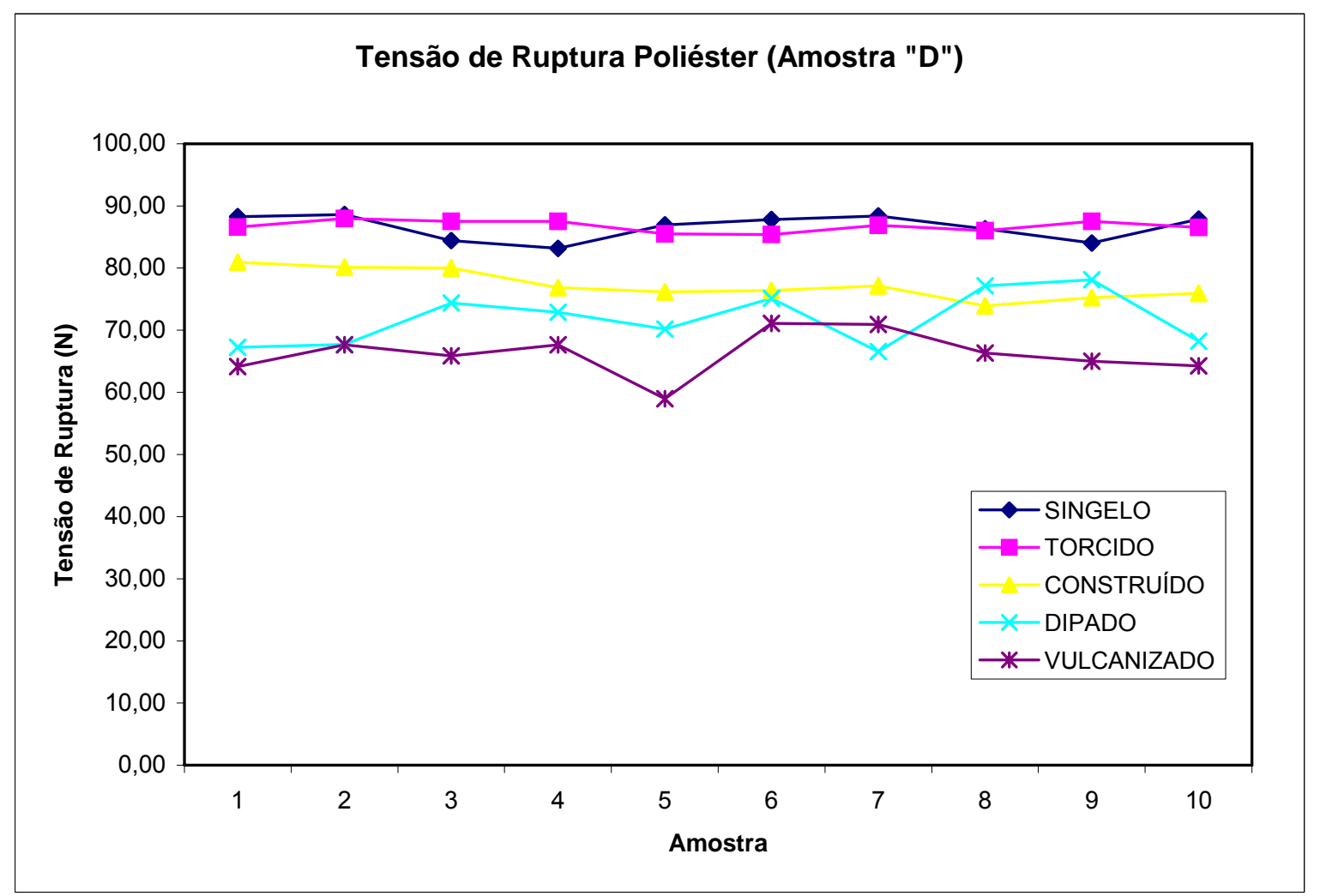

FIGURA 84. Resultados de tensão de ruptura da fibra de poliéster (Amostra "D") 


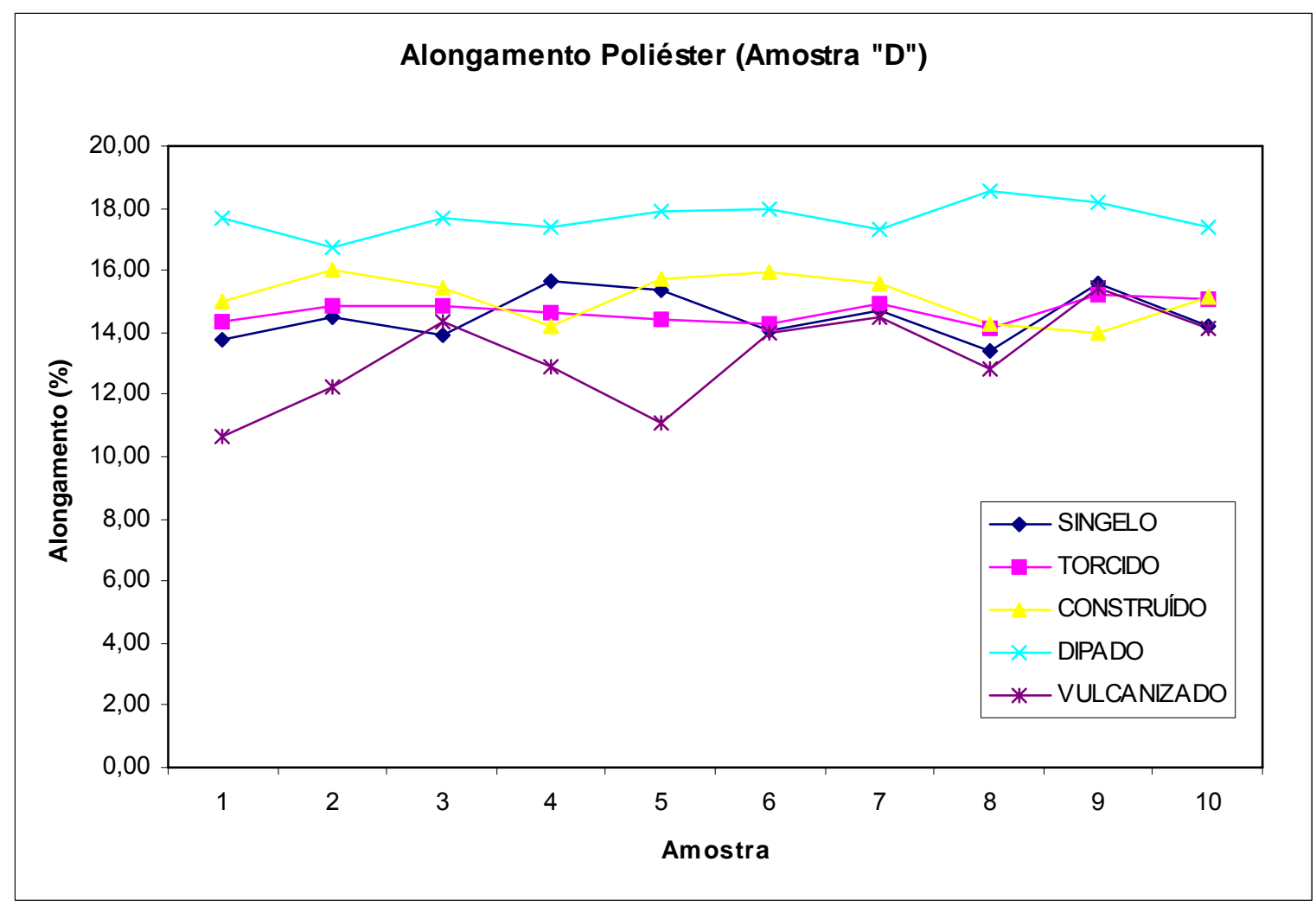

FIGURA 85. Resultados de alongamento da fibra de poliéster (Amostra "D")

Pelo gráfico de tensão de ruptura, observa-se que os resultados das fibras singelas e torcidas mantiveram-se estáveis, apresentando queda para as demais etapas, fato similar aos resultados da amostra C. As curvas de alongamento mostraram aumento nos resultados para a fibra dipada devido à variação da tensão aplicada nesta etapa, porém, ocorreu pequena queda após a vulcanização.

Em resumo, a partir dos comentários feitos anteriormente nas tabelas 11 a 14 e figuras 78 a 85 , observou-se queda nos resultados da tensão de ruptura nas etapas de construção, dipagem e vulcanização. Este fato pode ser mais bem explicado com um breve comentário a seguir.

O processo de construção do tecido apresentou perda das propriedades mecânicas das fibras provocada por tensões multiaxiais do tipo tração, compressão, flexão e impacto. Estas tensões foram mais bem explicadas no item 2.3.3.1.

O processo de dipagem das fibras prevê, após a aplicação da solução, a operação de estiramento-normalização, permitindo a adequação mais acurada das propriedades físicas do reforçante têxtil ao uso final. Nesta operação há uma perda das propriedades mecânicas, acrescida do aumento de alongamento das fibras (Godinho, 2003). 
Os polímeros são susceptíveis a degradação durante o processo térmico e a exposição a altas temperaturas, sobretudo na presença de umidade para o caso do poliéster. Embora a degradação térmica ocorra pela regeneração do monômero, ela usualmente é acompanhada pela formação de pequenas moléculas como ácido acético, metano, etileno, hidrogênio e $\mathrm{CO}_{2}$. A natureza dos produtos resultantes depende da atmosfera em que a degradação ocorre, ou seja, inerte (nitrogênio ou $\mathrm{CO}_{2}$ ) ou na presença de oxigênio. O processo de dipagem ocorre na presença de oxigênio e, em adição a degradação puramente térmica, obtém-se a degradação oxidativa. A degradação oxidativa tem na sua principal função o envelhecimento do polímero, o que resulta na perda de propriedades mecânicas. Nas Figuras 86 e 87 observa-se a perda das propriedades com o tempo de exposição à temperatura para o poliéster e o náilon 6.6 (Abbas, 2006).

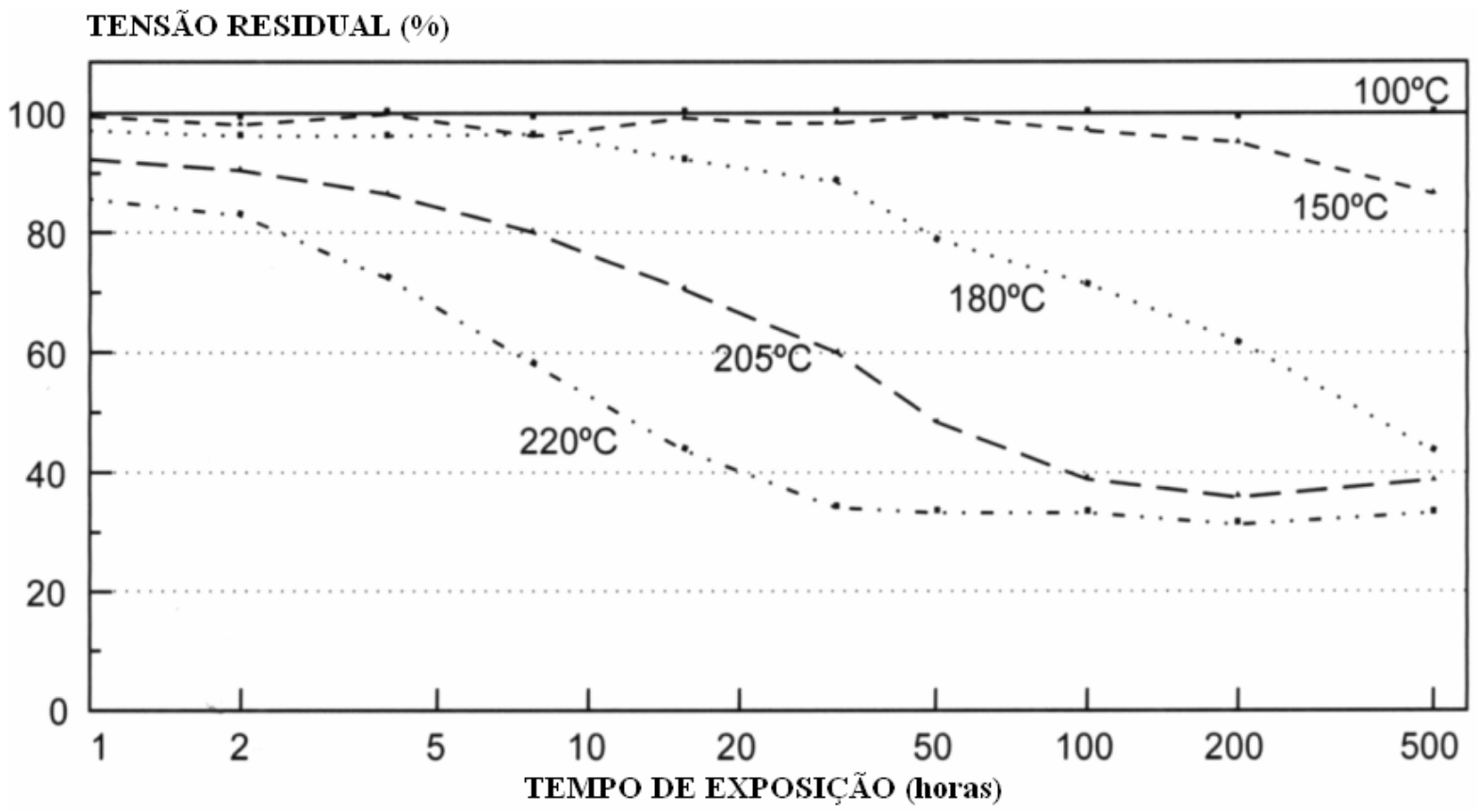

FIGURA 86. Perda residual por temperatura para o poliéster 
TENSÃO RESIDUAL (\%)

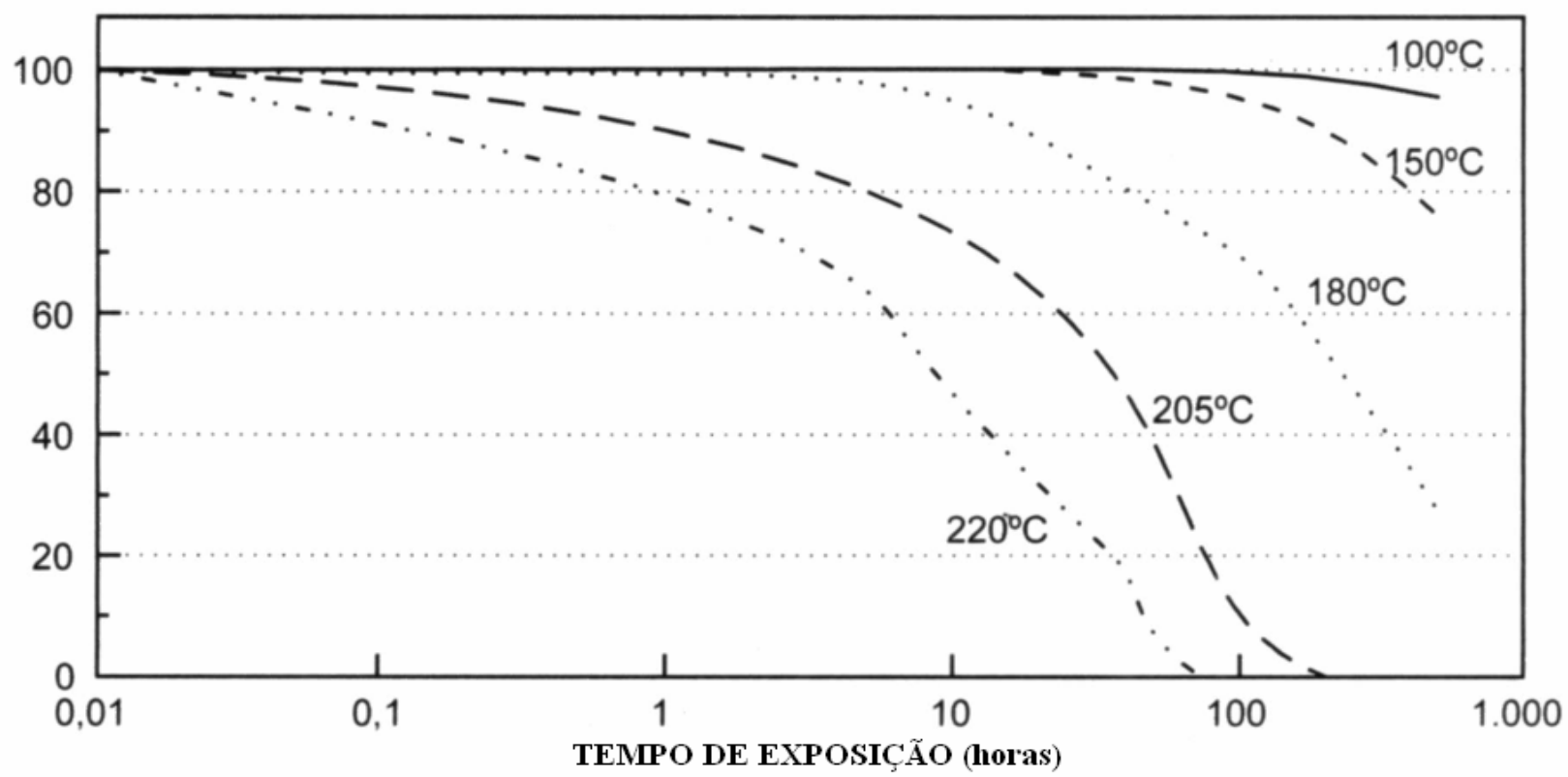

FIGURA 87. Perda residual por temperatura para o náilon 6.6

No processo de dipagem, o tecido foi submetido na $1^{\text {a }}$ zona a um tempo de exposição em torno de 10 minutos e temperatura na ordem de $150{ }^{\circ} \mathrm{C}$ e na $2^{\mathrm{a}}$ zona a um tempo de exposição em torno de 6,4 minutos e temperatura na ordem de $220^{\circ} \mathrm{C}$. Com base no exposto, confirmou-se a existência de perda de propriedades mecânicas para o poliéster e o náilon 6.6, quando expostos às condições de tempo de exposição e temperatura no processo de dipagem (Cardoso; Andrade, 2009a). 


\subsection{Ensaio de tração monitorado com ajuste de tensão manual}

Nas Figuras 88 a 99 são mostradas a sequência de fratura para a fibra de poliéster do tipo singelo, em vista total da fibra e detalhe de fratura dos filamentos com maior ampliação, sendo a tensão aplicada manualmente conforme metodologia descrita no item 3.2.2.

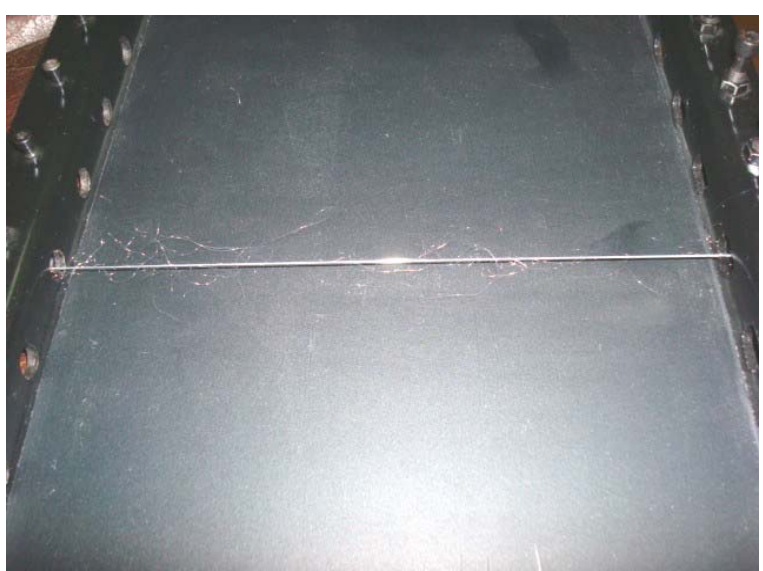

FIGURA 88. Início da fratura $80 \%$ de carga

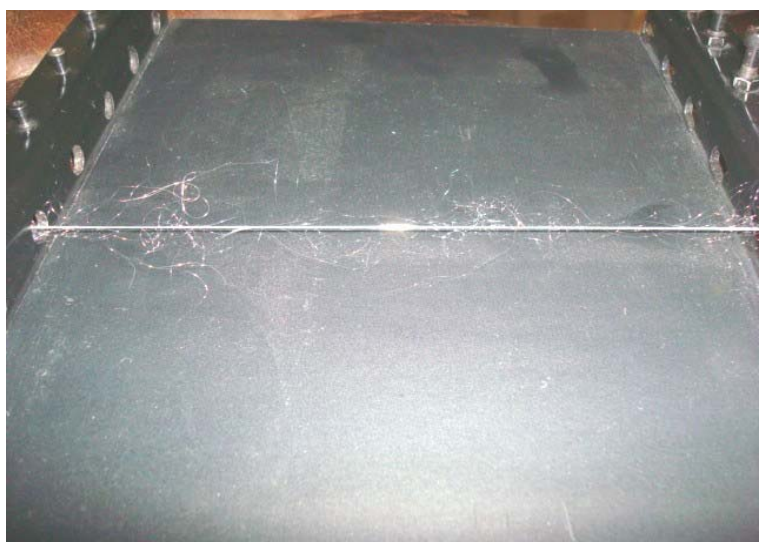

FIGURA 90. Fratura com $85 \%$ de carga

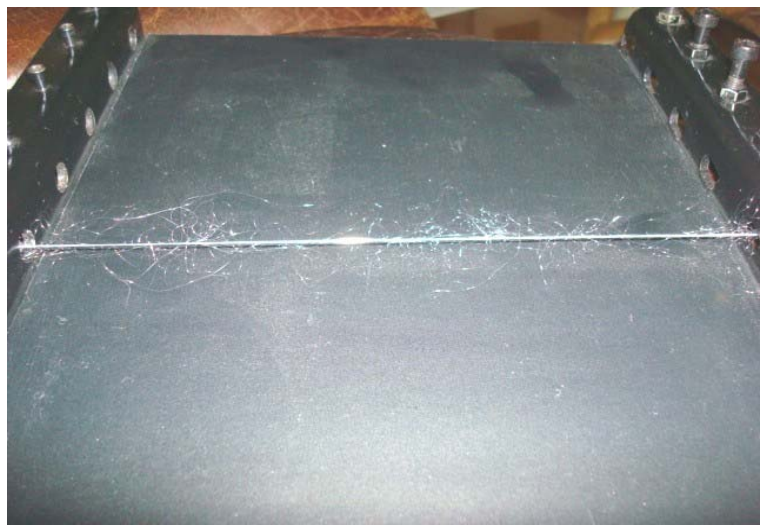

FIGURA 92. Fratura com $88 \%$ de carga

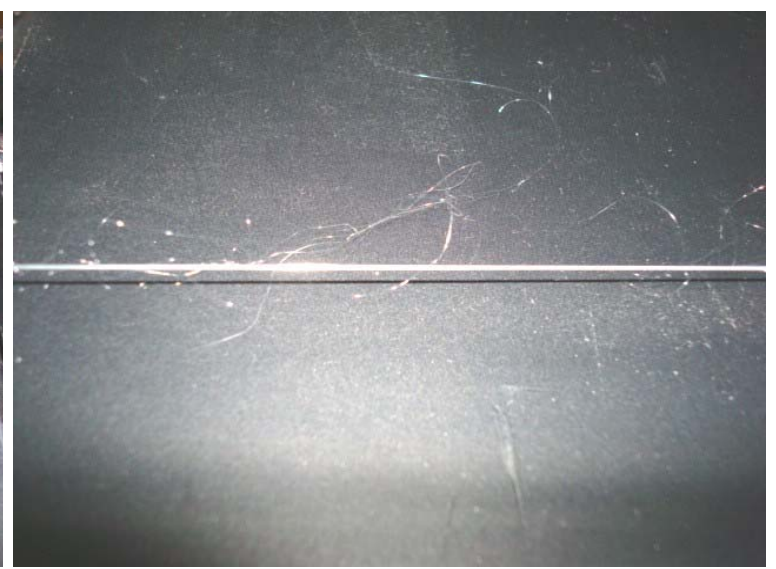

FIGURA 89. Detalhe da fratura $80 \%$ de carga

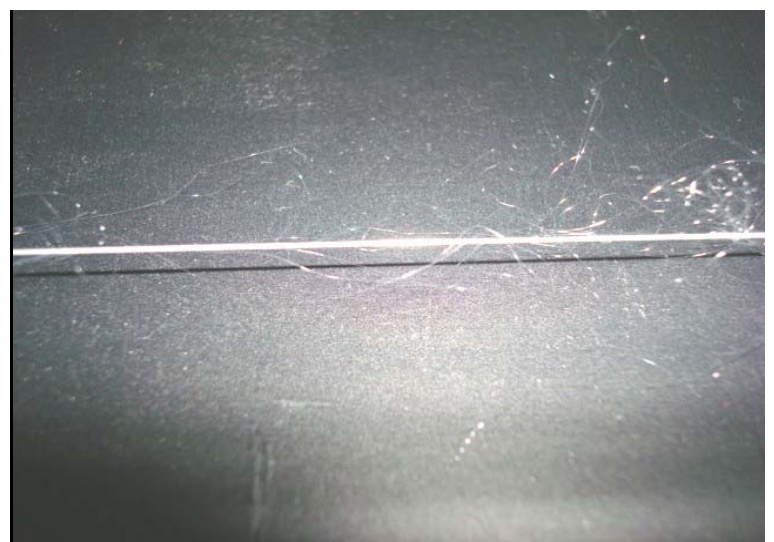

FIGURA 91. Detalhe da fratura $85 \%$ de carga

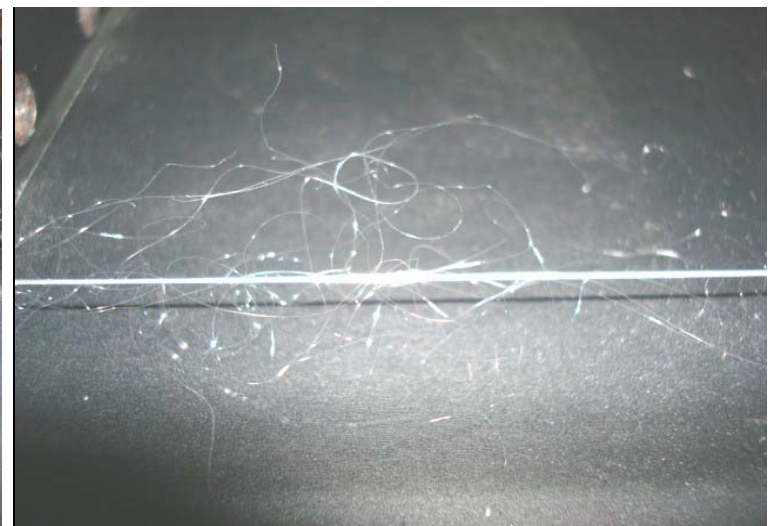

FIGURA 93. Detalhe da fratura $88 \%$ de carga 


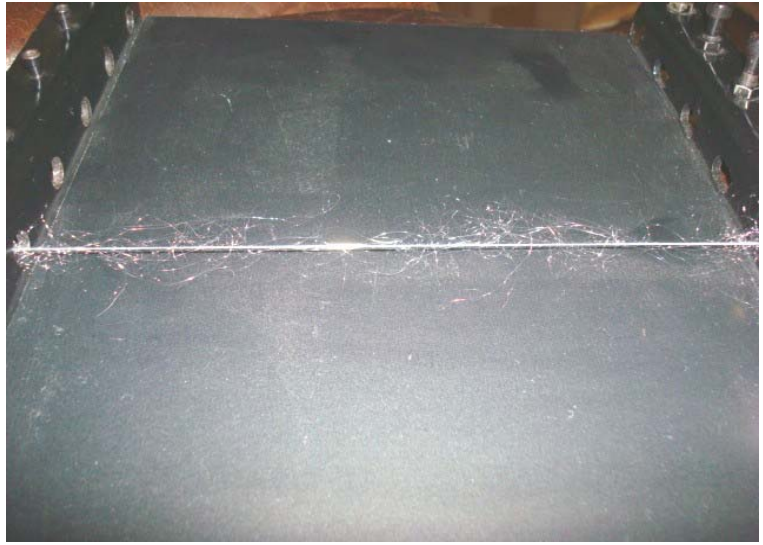

FIGURA 94. Fratura com 90\% de carga

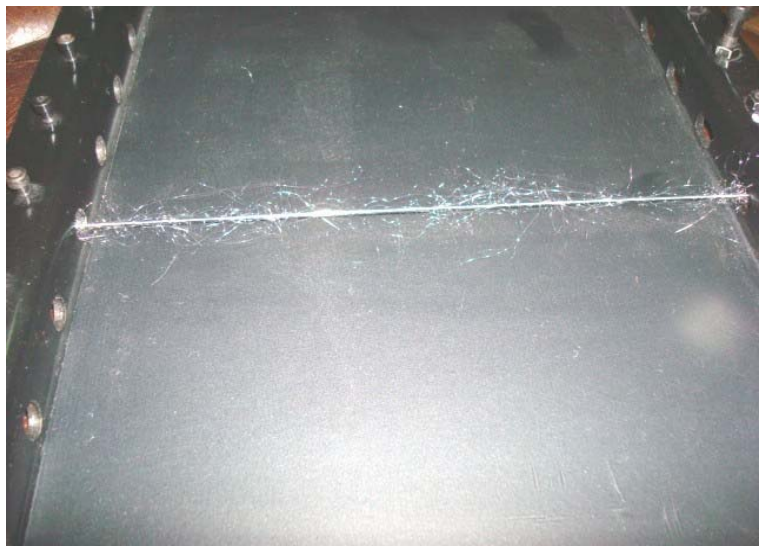

FIGURA 96. Fratura com 93\% de carga

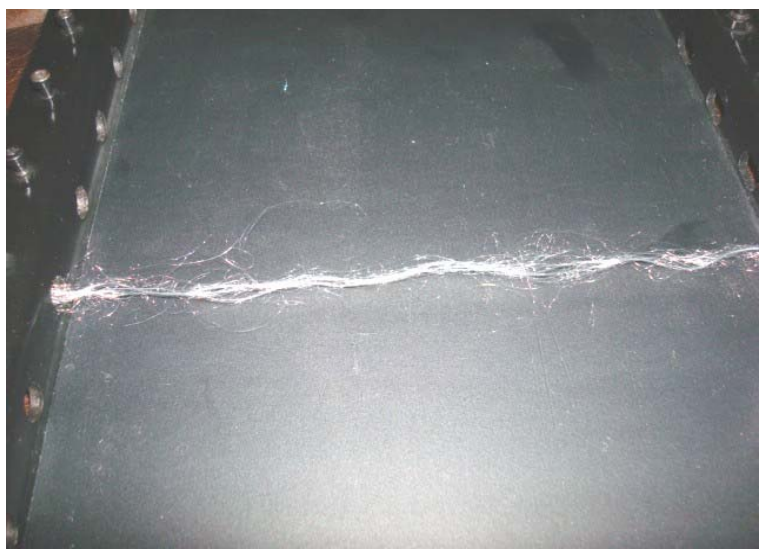

FIGURA 98. Fratura com 95\% de carga

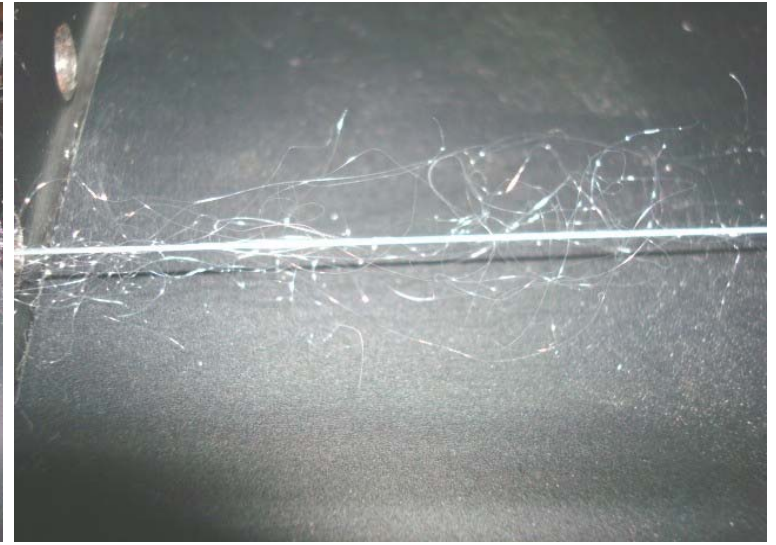

FIGURA 95. Detalhe da fratura 90\% de carga

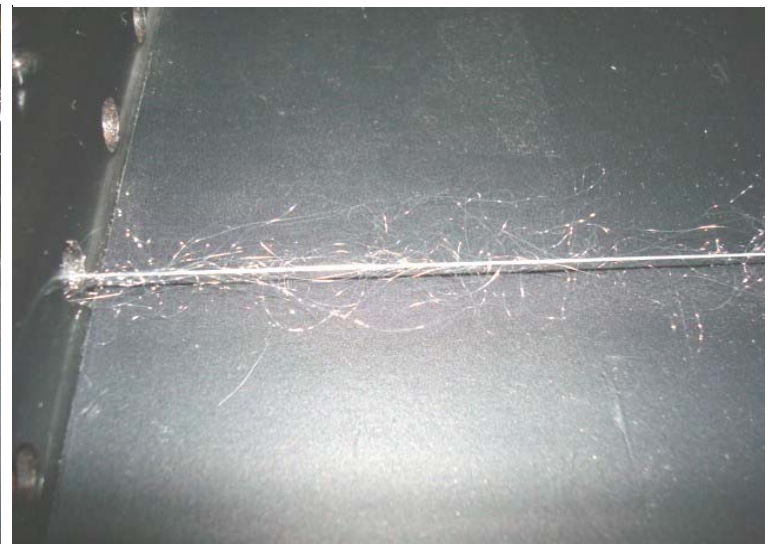

FIGURA 97. Detalhe da fratura 93\% de carga

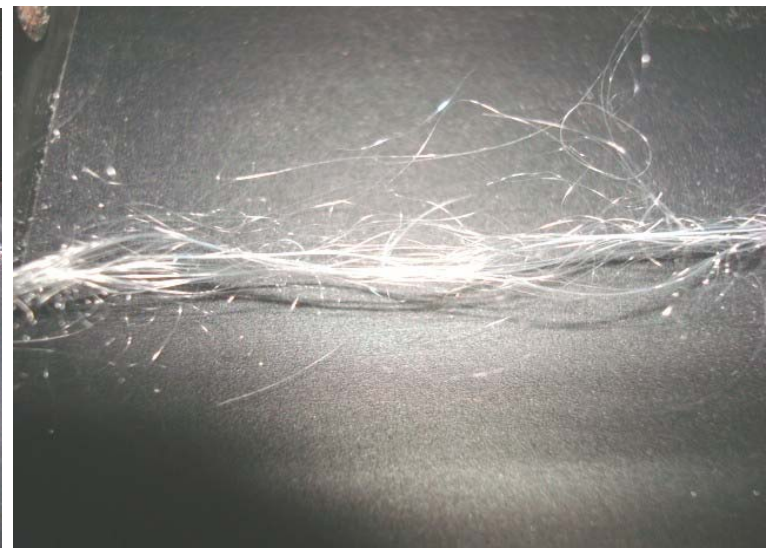

FIGURA 99. Detalhe da fratura 95\% de carga

Durante as etapas de carregamento, constatou-se que houve diferença no tensionamento da fibra, na qual, na medida em que se aumentou a tensão, os filamentos romperam-se parcialmente mantendo-se a integridade de uma parcela restante de filamentos. Com aproximadamente $97 \%$ de carga, ocorreu a fratura, porém, muitos filamentos ainda não tinham rompido totalmente. 
Conforme citado no item 2.1.8, a estatística de Weibull é geralmente usada para prognosticar a força testada em diferentes volumes (espessura, comprimento, área), para prever a resistência do feixe de fibras e finalmente estimar a ruptura dos compósitos reforçados com fibras. No final deste trabalho, conforme APÊNDICE $A$, é mostrado o início de um estudo da probabilidade de falha e alguns comentários para as fibras de náilon e poliéster do tipo singelas.

\subsection{Ensaio de tração monitorado do tecido dipado}

Nas Figuras 100 a 102 são mostradas a sequência do ensaio de tração para o tecido dipado de náilon até a fratura e nas Figuras 103 a 105 são mostradas, com maior ampliação, algumas das etapas com cargas intermediárias aplicadas. $\mathrm{O}$ ensaio foi realizado na velocidade de $100 \mathrm{~mm} /$ minuto e as cargas intermediárias monitoradas pelo computador.

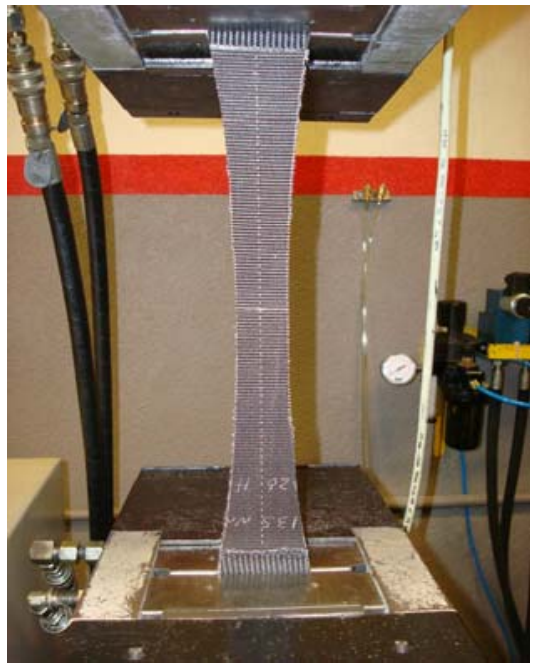

FIGURA 100. Ensaio do tecido de náilon

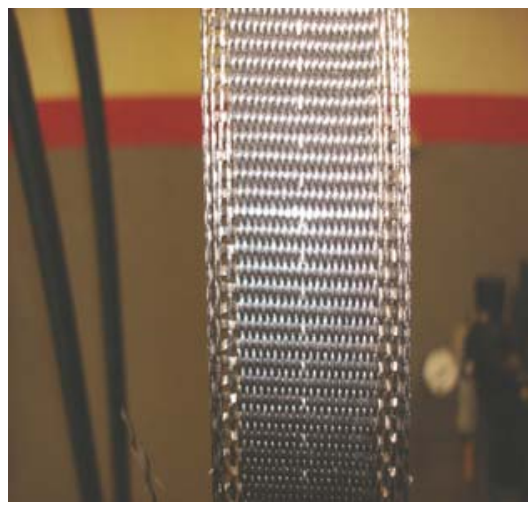

FIGURA 103. 20\% da carga aplicada

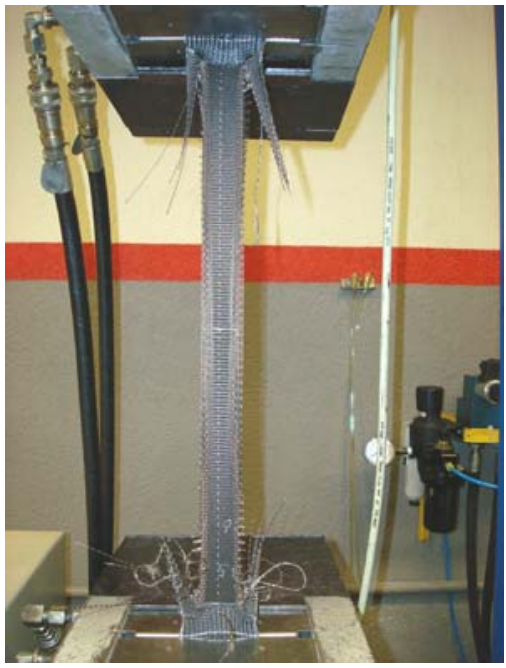

FIGURA 101. 90\% da carga aplicada

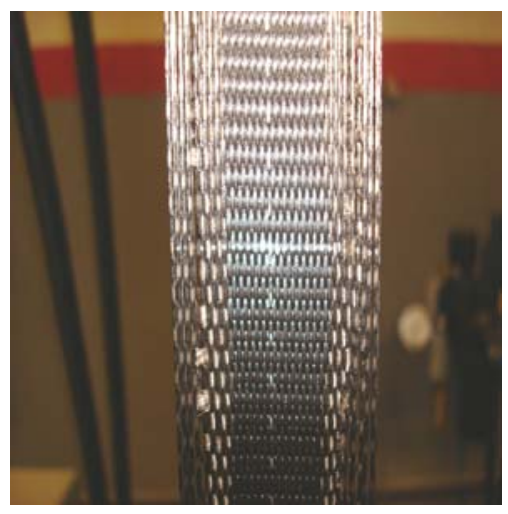

FIGURA 104. 60\% da carga aplicada

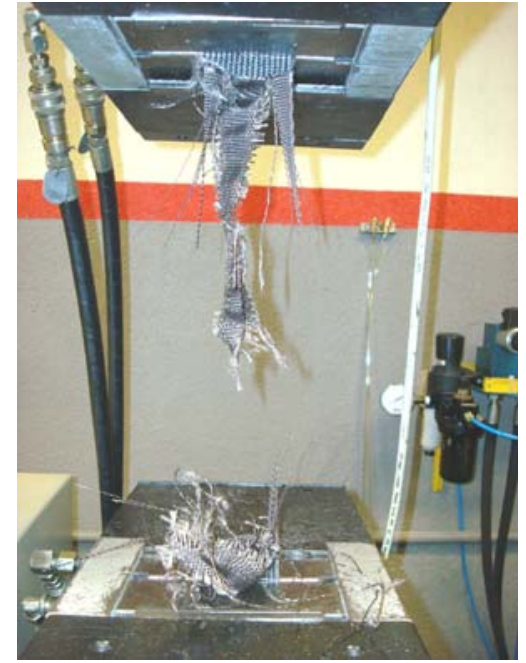

FIGURA 102. Fratura do tecido

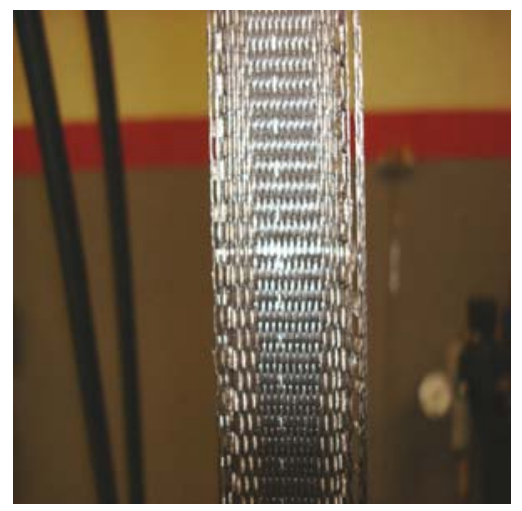

FIGURA 105. $85 \%$ da carga aplicada 
Nas figuras 106 a 108 são mostradas a sequência do ensaio de tração para o tecido dipado de poliéster até a fratura e nas Figuras 109 a 111 são mostradas, com maior ampliação, algumas das etapas com cargas intermediárias.

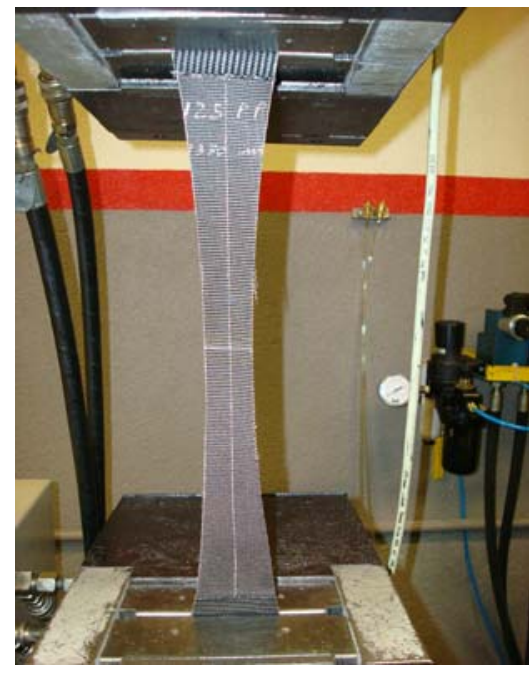

FIGURA 106-Ensaio do tecido de poliéster

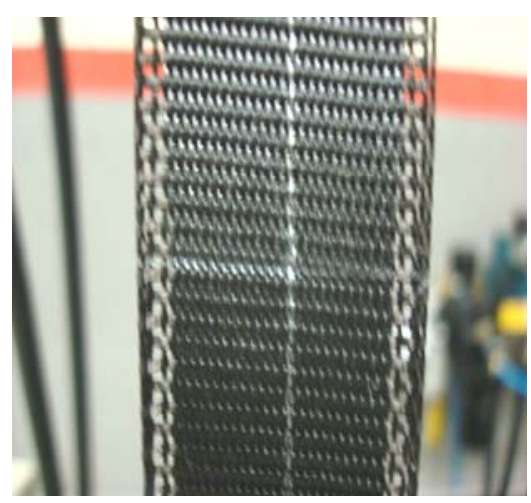

FIGURA 109. 15\% da carga aplicada

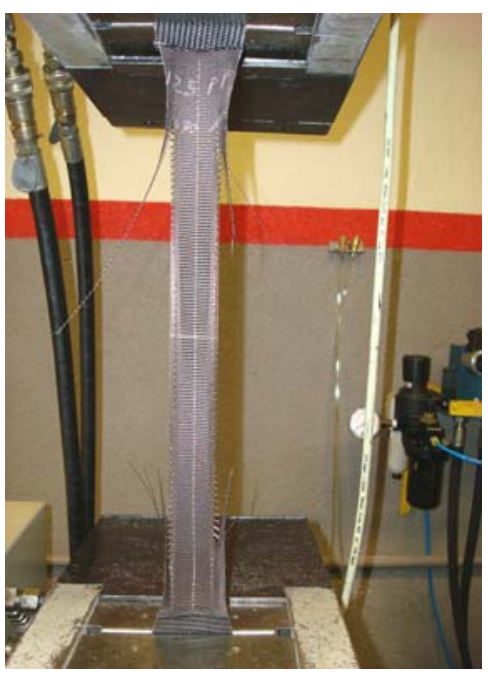

FIGURA 107 - 85\% da carga aplicada

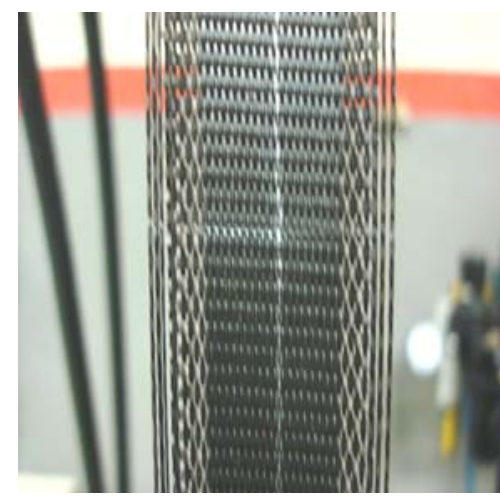

FIGURA 110. 50\% da carga aplicada

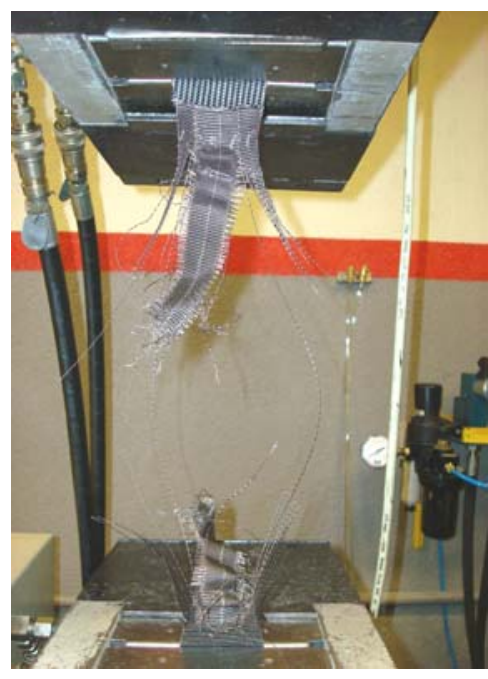

FIGURA 108 - Fratura do tecido

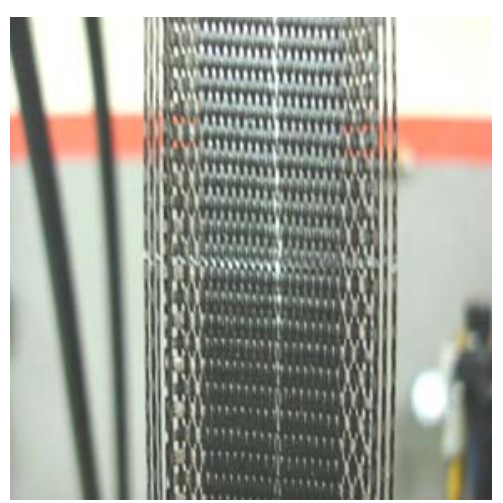

FIGURA 111. $80 \%$ da carga aplicada

Da mesma forma, conforme descrito no ensaio de tração monitorado com ajuste de tração manual no item 4.2, as etapas de carregamento do tecido mostraram haver diferença no tensionamento das fibras, na qual, a medida em que se aumentava a tensão, uma parcela das fibras romperam mantendo-se a integridade do restante das fibras do tecido. Observou-se também que a diferença no tensionamento do tecido foi inferior ao da fibra, muito provavelmente pelos aumentos na coesão e na homogeneidade das fibras pelo tratamento termo químico realizado na etapa de dipagem do tecido. 
Como estudo adicional, foi feita alteração na velocidade do ensaio de ruptura em uma amostra de cada um dos tecidos de náilon e poliéster, de 100 $\mathrm{mm} /$ minuto para $5 \mathrm{~mm} /$ minuto, com o objetivo de analisar detalhadamente $\mathrm{o}$ mecanismo de fratura e a curva após o pico de tensão máxima. Nas Figuras 112 e 113 são mostrados os gráficos selecionados para os ensaios de ruptura dos tecidos de náilon e poliéster com a velocidade de $5 \mathrm{~mm} / \mathrm{minuto}$.

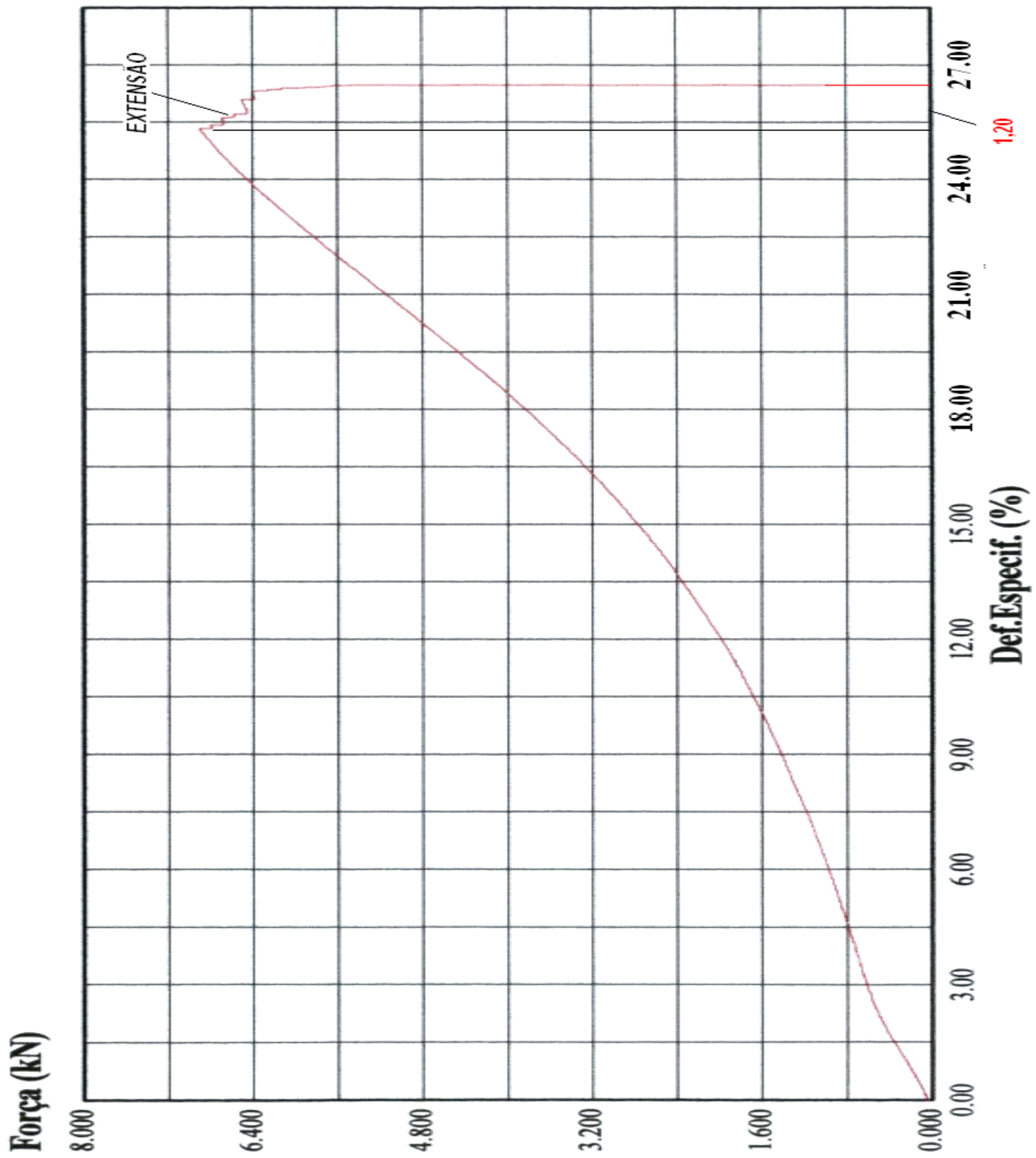

FIGURA 112. Gráfico tensão x deformação para o tecido dipado de náilon 


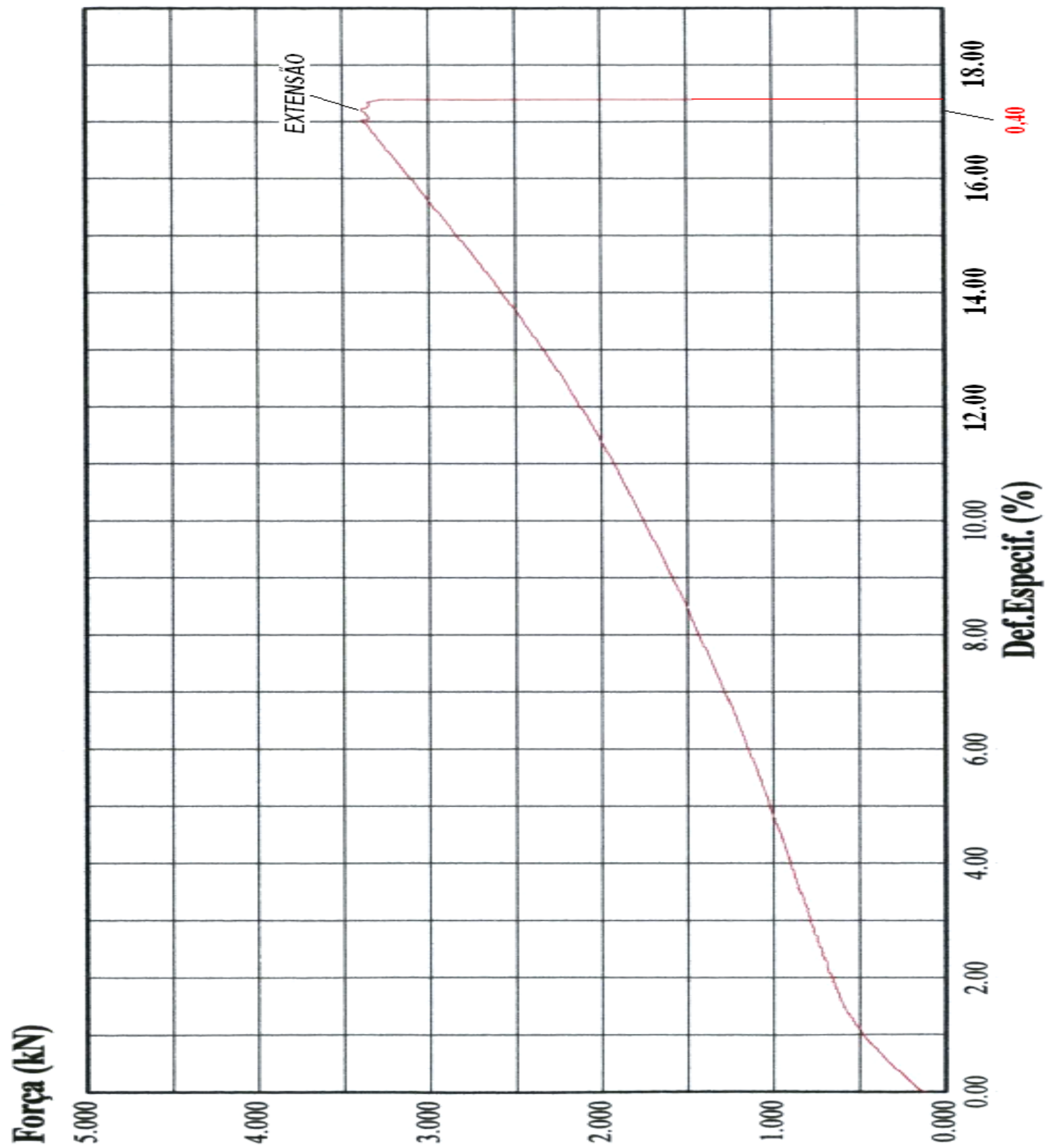

FIGURA 113. Gráfico tensão x deformação para o tecido dipado de poliéster

Observa-se nos gráficos tensão $\mathrm{x}$ deformação com velocidade reduzida para $5 \mathrm{~mm} /$ minuto, o surgimento de uma extensão da curva na zona de fratura, após o pico de tensão máxima, de 1,2\% para o náilon e $0,4 \%$ para o poliéster. Este fenômeno é explicado pela variação das tensões individuais das fibras durante o carregamento, ou seja, a região estendida representa a ruptura de algumas fibras que não fraturam quando se atinge a tensão máxima de ruptura dos tecidos. 


\subsection{Ensaios por microscopia eletrônica de varredura}

Nas Figuras 114 a 118 são mostrados os perfis dos filamentos de náilon do tipo singelos sem rompimento.
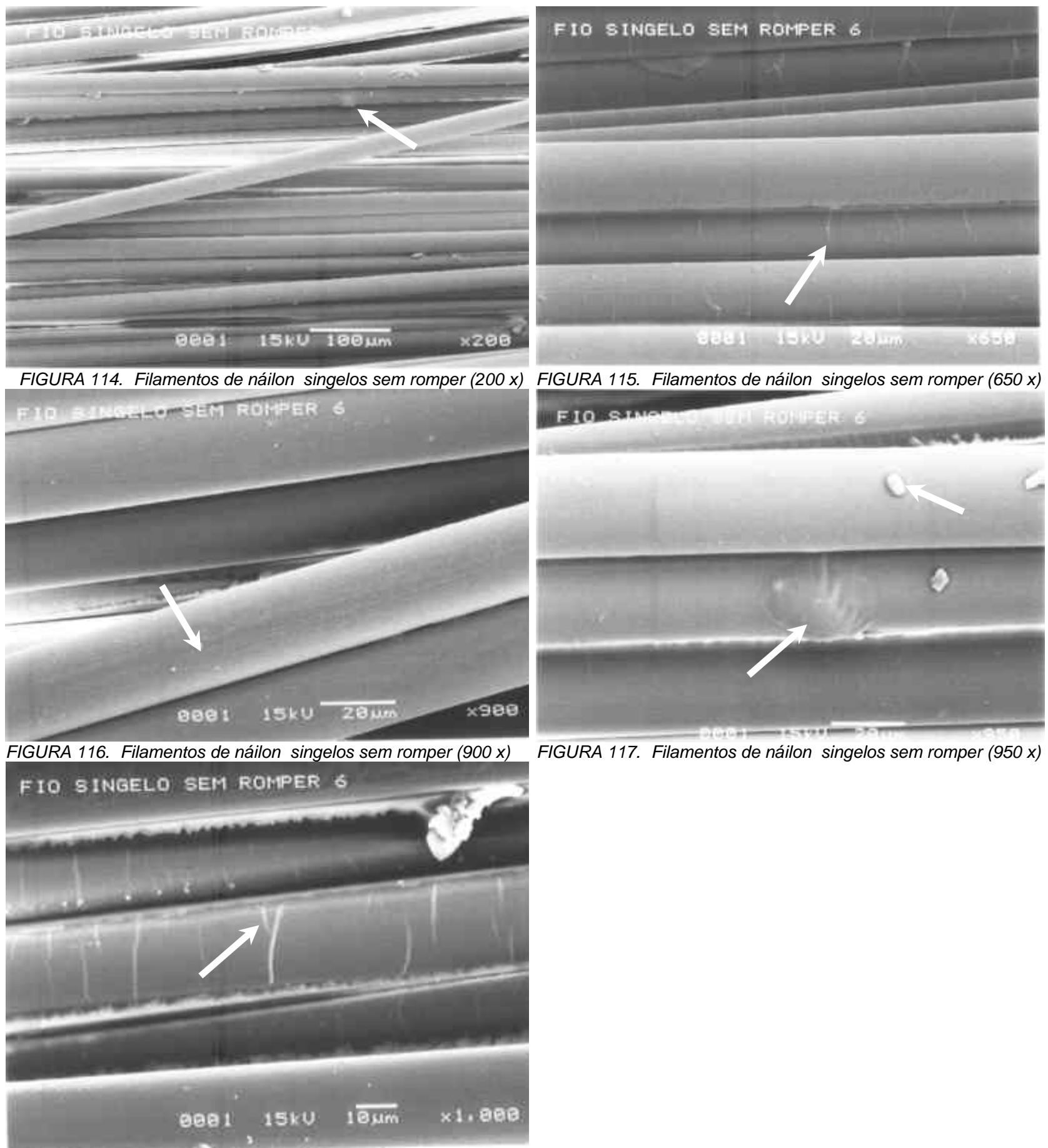

FIGURA 115. Filamentos de náilon singelos sem romper (650 x)

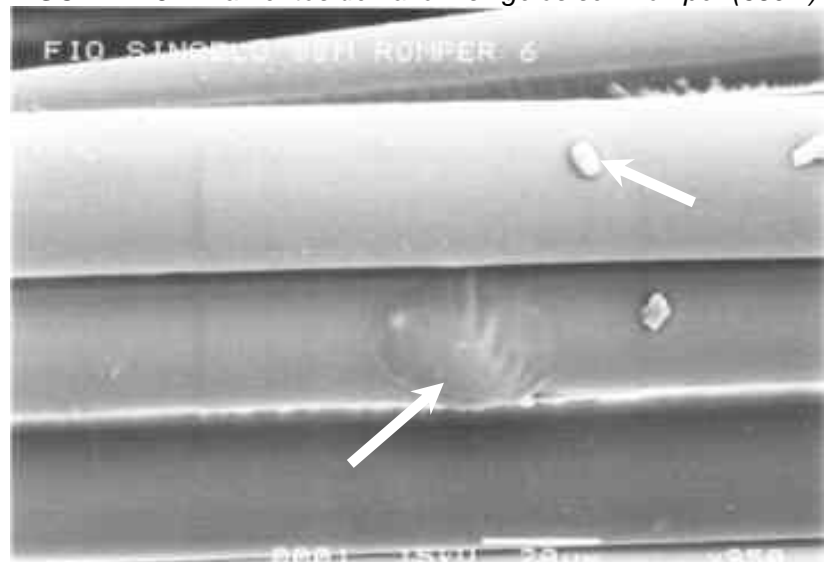

FIGURA 117. Filamentos de náilon singelos sem romper $(950 x)$

FIGURA 118. Filamentos de náilon singelos sem romper (1000x)

Nas Figuras 114 e 116 observa-se sinais de contaminações por partículas e nas figuras 115 e 118 manchas na superfície dos filamentos de náilon. Na figura 117 verifica-se também contaminação por partículas e ponto de deformação plástica em um dos filamentos. 
Nas Figuras 119 a 123 são mostrados os perfis dos filamentos de náilon do tipo torcidos sem rompimento.
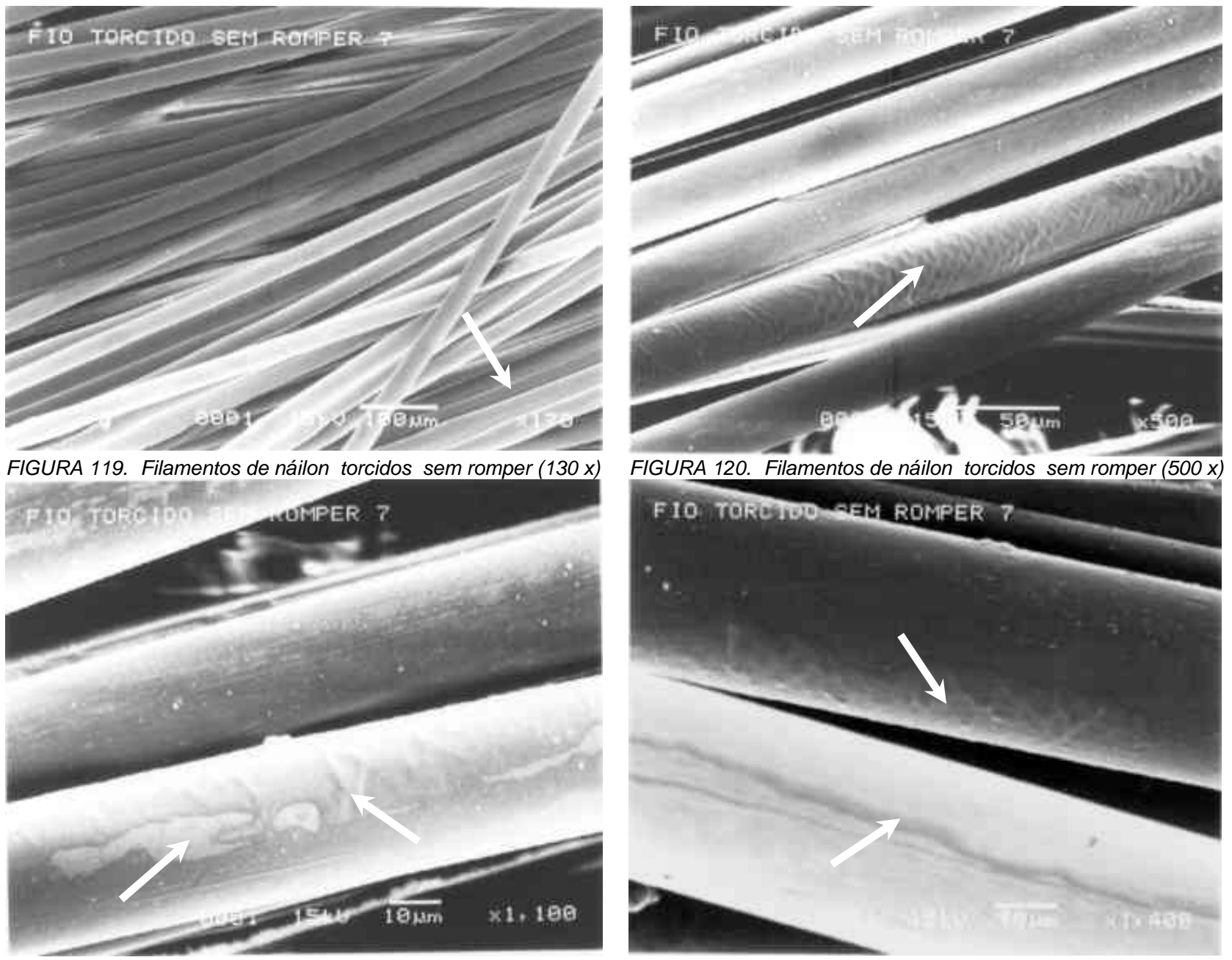

FIGURA 121. Filamentos de náilon torcidos sem romper (1100x)

FIGURA 122. Filamentos de náilon torcidos sem romper (1400x)

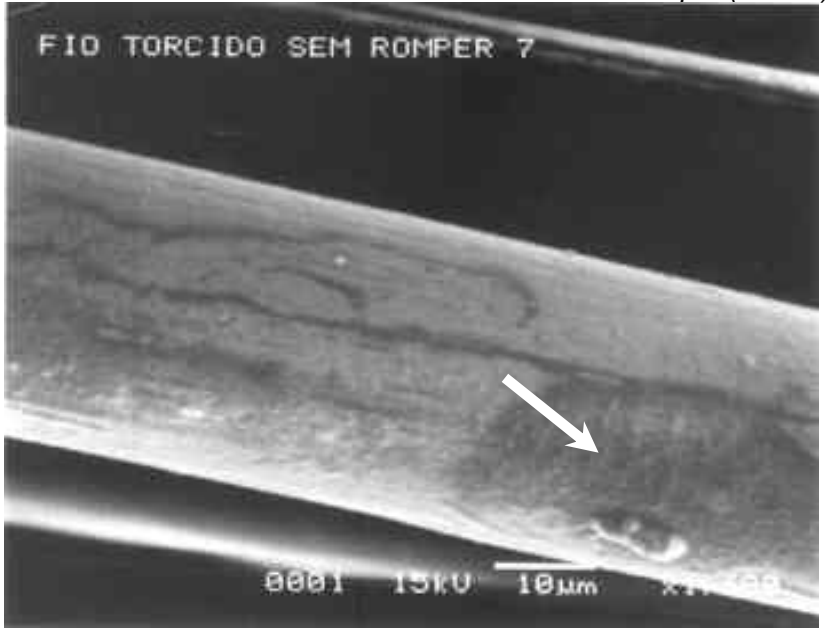

FIGURA 123. Filamentos de náilon torcidos sem romper (1600 x)

Nas figuras 119, 120 e 122 observa-se sinais de deformação do tipo rugas na superfície dos filamentos de náilon tipo torcidos. Nas Figuras 121 a 123 são mostradas manchas superficiais. 
Nas Figuras 124 a 129 são mostrados os perfis dos filamentos de náilon do tipo construídos sem rompimento.

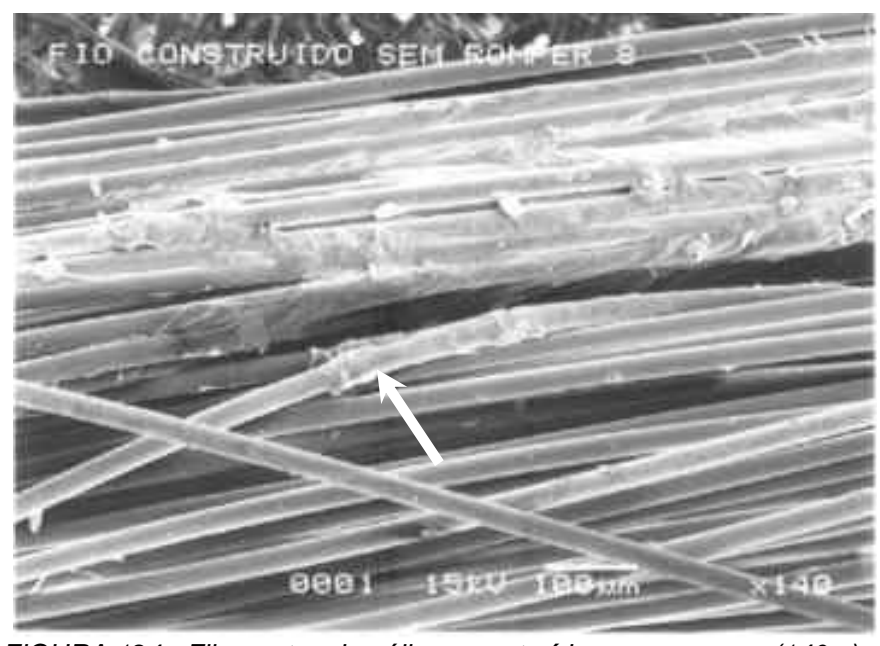

FIGURA 124. Filamentos de náilon construídos sem romper (140 x)
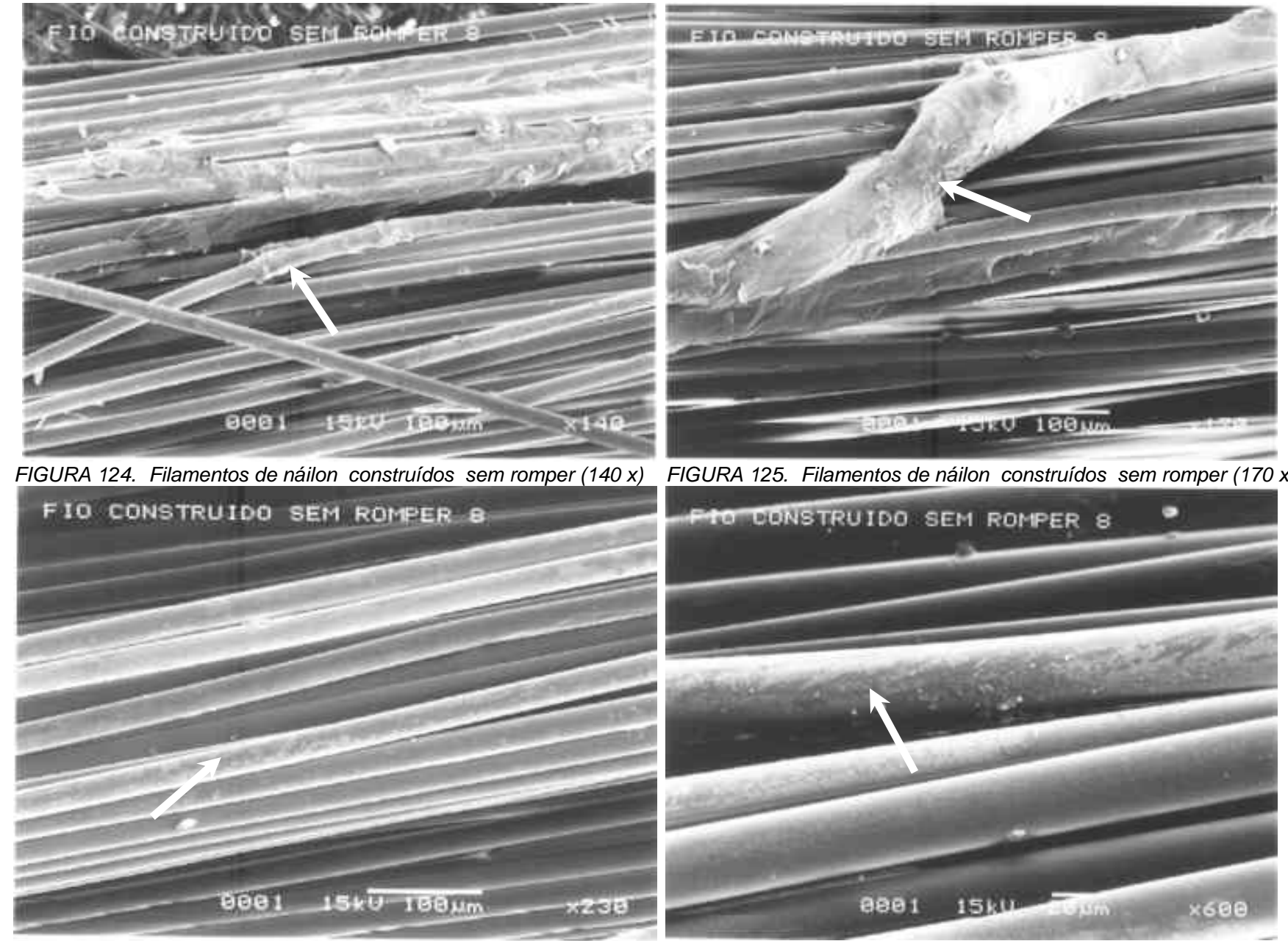

FIGURA 125. Filamentos de náilon construídos sem romper (170 x)

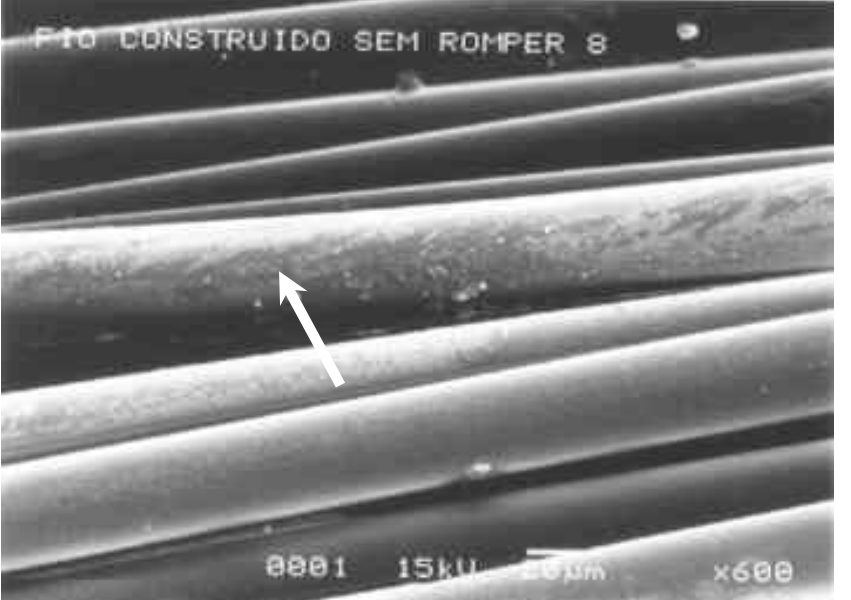

FIGURA 126. Filamentos de náilon construídos sem romper $(230 x)$
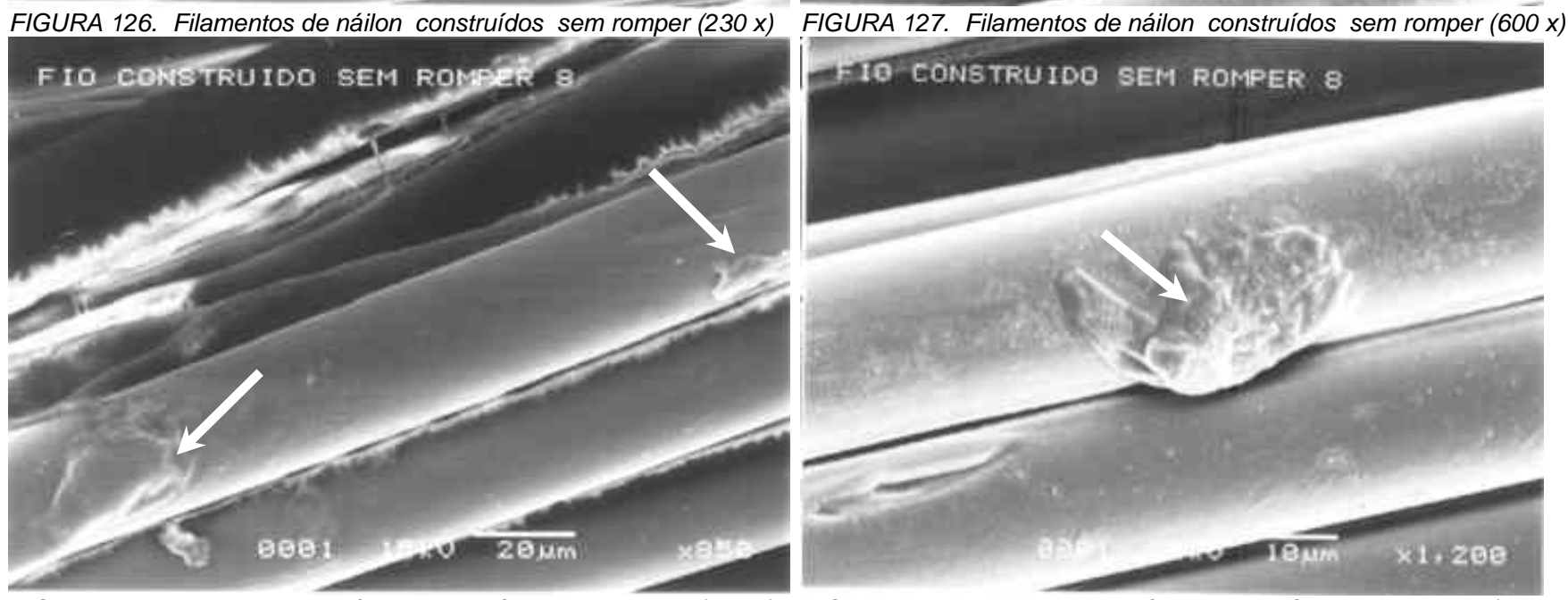

FIGURA 128. Filamentos de náilon construídos sem romper (850 x)

FIGURA 129. Filamentos de náilon construídos sem romper (1200x)

Pode ser observado na superfície dos filamentos de náilon tipo construídos sinais de deformação plástica nas Figuras 124 e 125, manchas nas Figuras 126 e 127 e contaminações nas Figuras 128 e 129. 
Nas Figuras 130 a 135 são mostrados os perfis dos filamentos de náilon do tipo dipados sem rompimento.
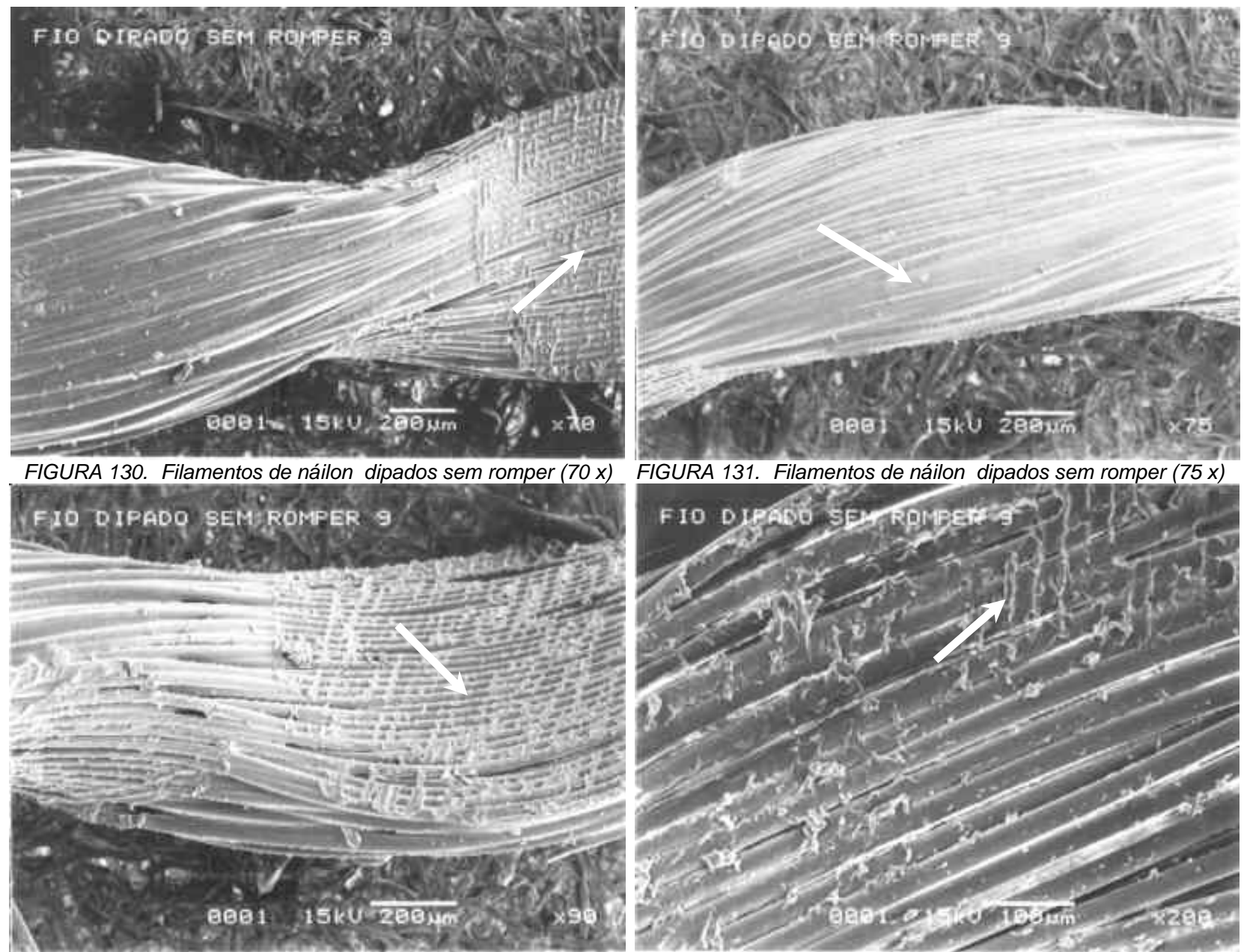

FIGURA 131. Filamentos de náilon dipados sem romper $(75 x)$
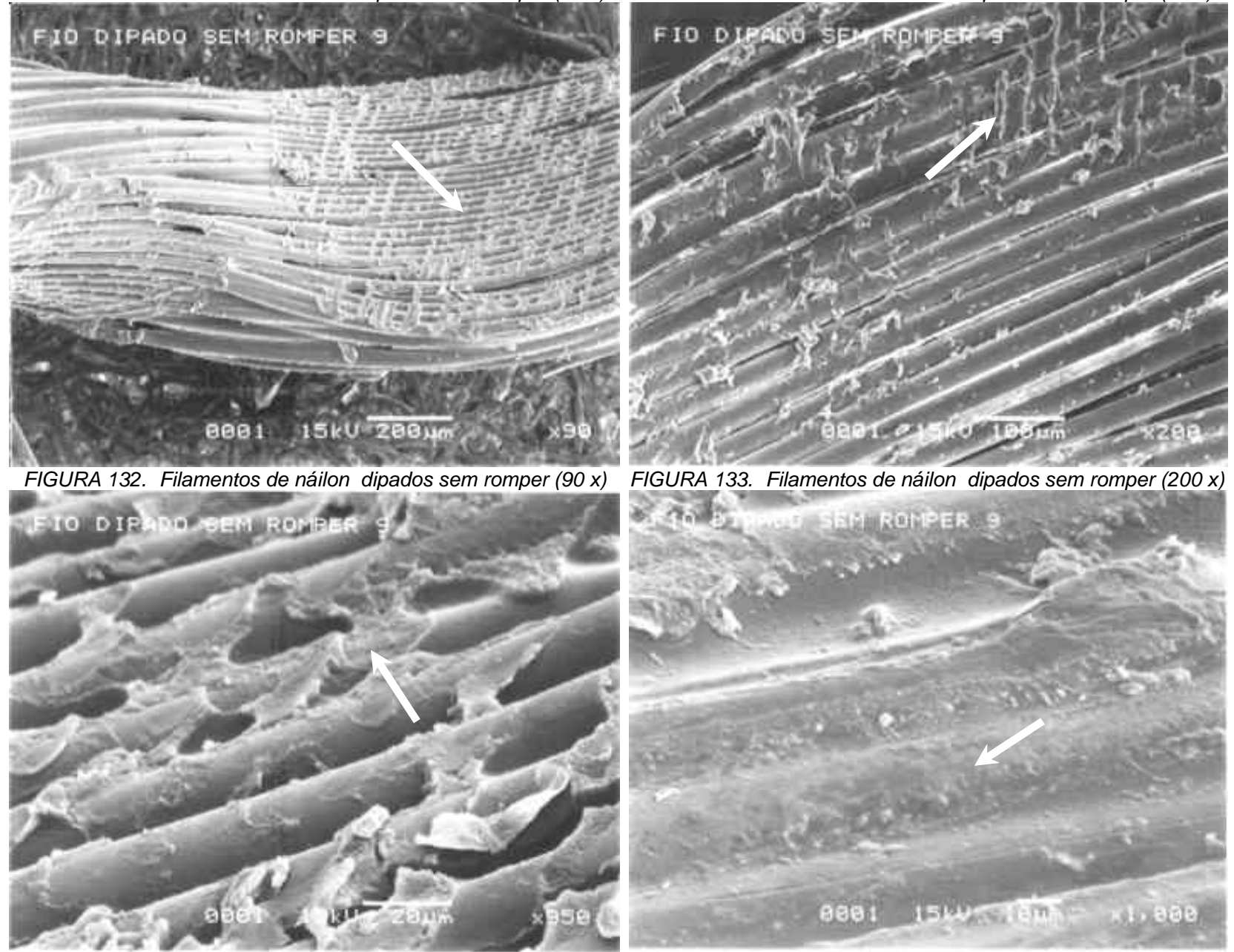

FIGURA 134. Filamentos de náilon dipados sem romper (950x) FIGURA 135. Filamentos de náilon dipados sem romper (1000x) Pode ser observado na superfície dos filamentos de náilon tipo dipados marcas de contato da fibra da trama nas Figuras 130 a 134 e intensa impregnação da solução de dipagem entre os filamentos na Figura 135. Na figura 134 são mostrados os pontos de falha na impregnação da solução de dipagem, devido ao contato da fibra durante esta etapa de processamento. 
Nas Figuras 136 a 141 são mostrados os perfis dos filamentos de náilon do tipo vulcanizados sem rompimento.
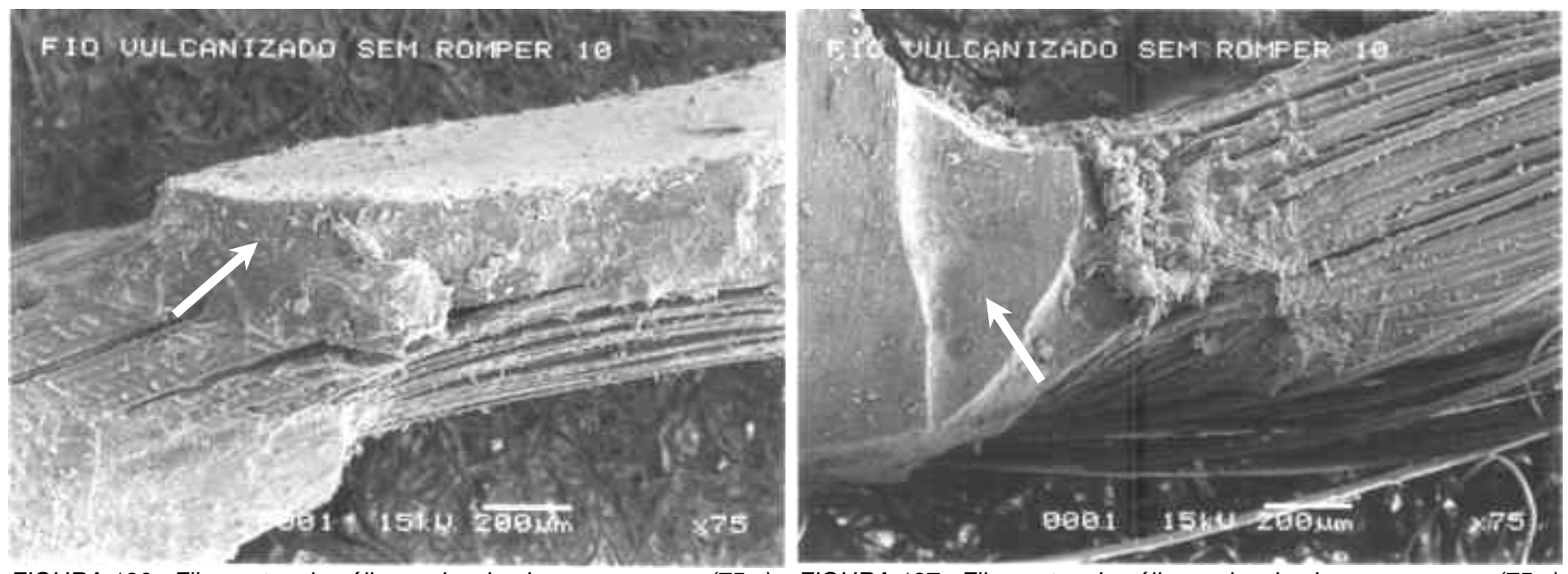

FIGURA 136. Filamentos de náilon vulcanizados sem romper $(75 x)$

FIGURA 137. Filamentos de náilon vulcanizados sem romper $(75 x)$
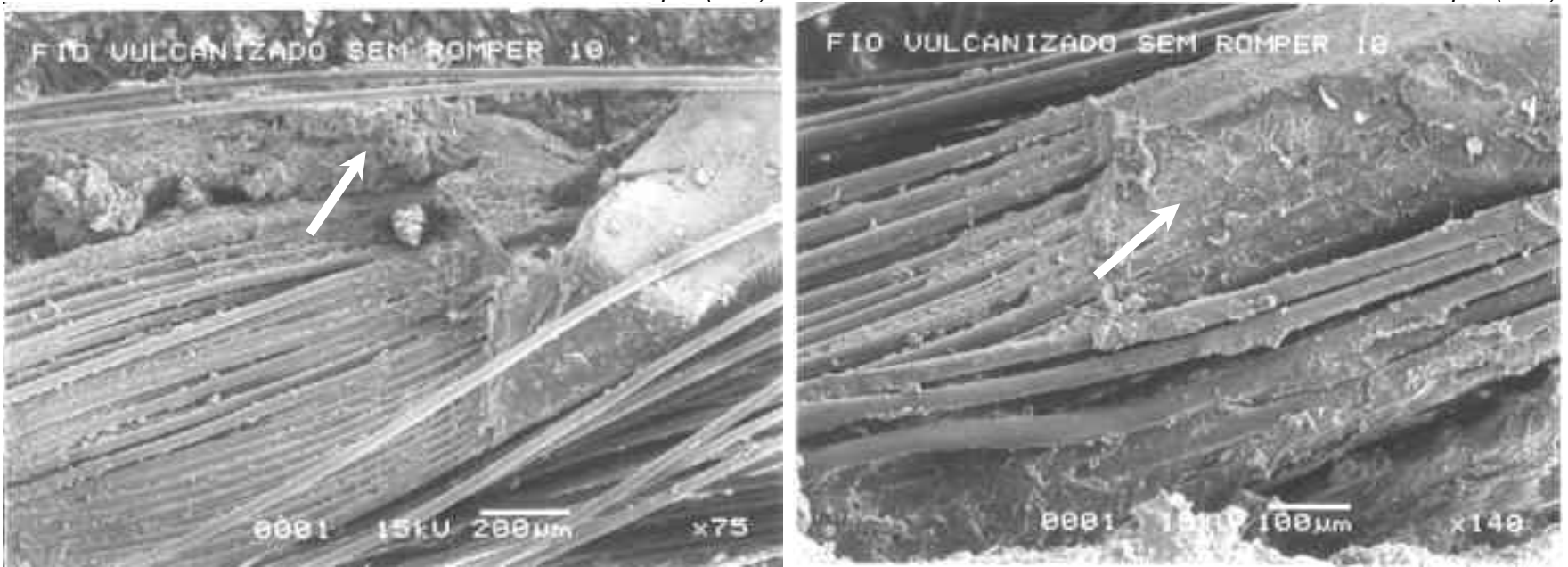

FIGURA 138. Filamentos de náilon vulcanizados sem romper $(75 x)$ FIGURA 139. Filamentos de náilon vulcanizados sem romper (140x)
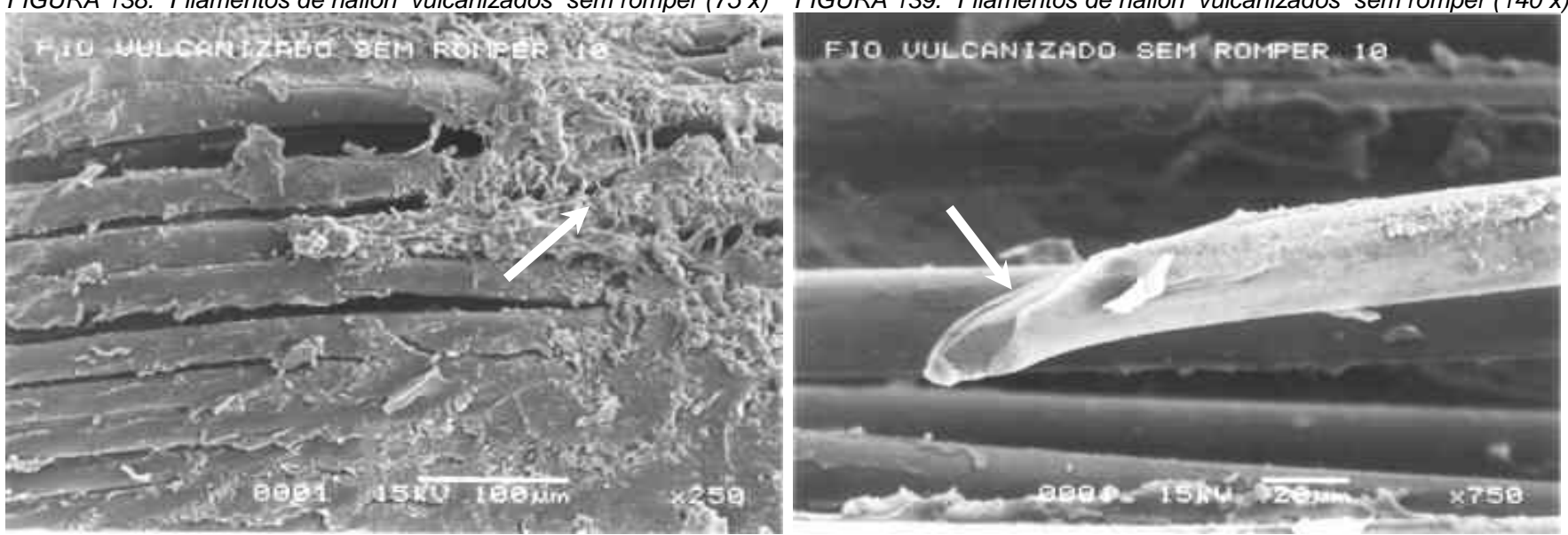

FIGURA 140. Filamentos de náilon vulcanizados sem romper $(250$ x) FIGURA 141. Filamentos de náilon vulcanizados sem romper (750 x)

Pode ser observado na superfície dos filamentos de náilon tipo vulcanizados regiões de intensa impregnação de borracha nas Figuras 136 a 141. Na figura 141 é mostrada a fratura em um dos filamentos. 
Nas Figuras 142 a 146 são mostrados os perfis de fratura para os filamentos de náilon do tipo singelos e rompidos.

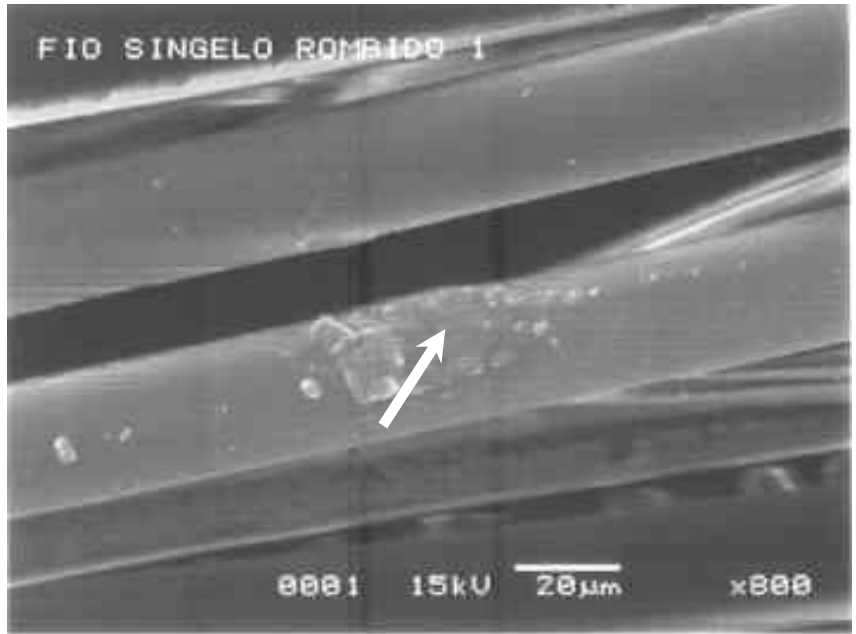

FIGURA 142. Filamentos de náilon singelos e rompidos (800 x)

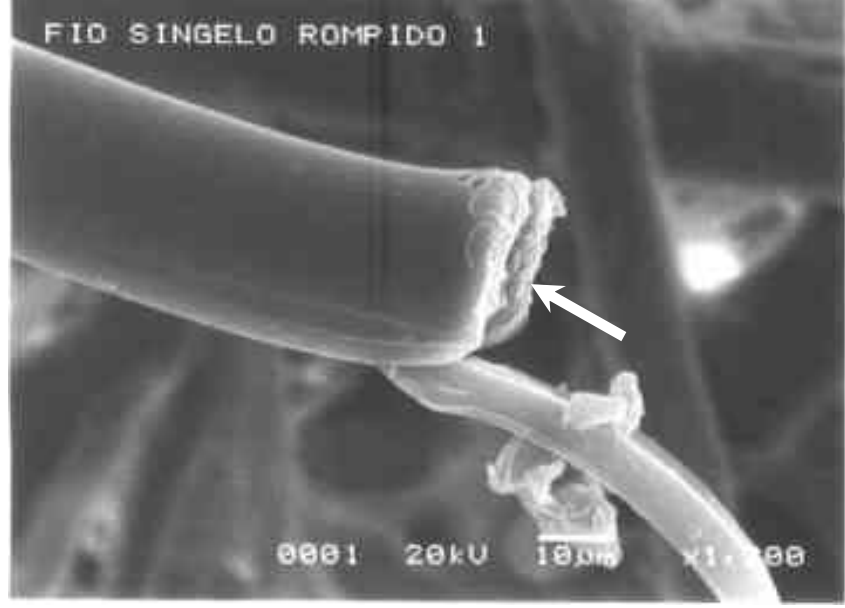

FIGURA 144. Filamentos de náilon singelos e rompidos (1200 x)

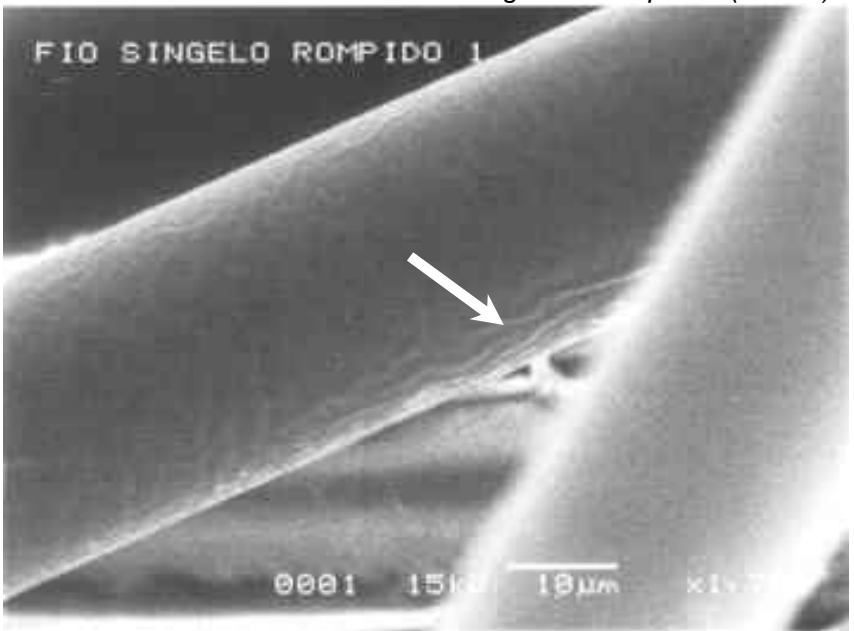

FIGURA 146. Filamentos de náilon singelos e rompidos (1700x)

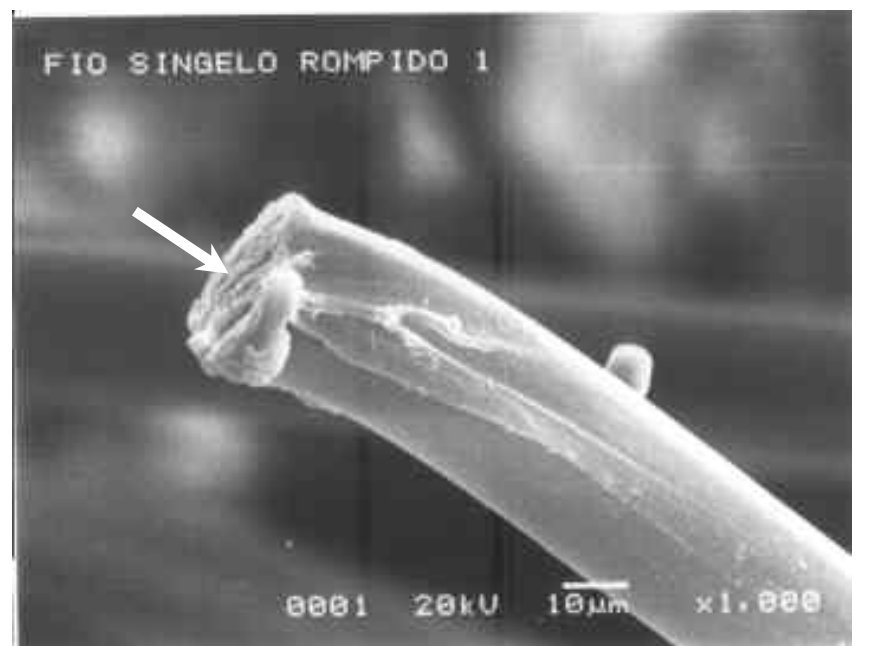

FIGURA 143. Filamentos de náilon singelos e rompidos (1000 x)

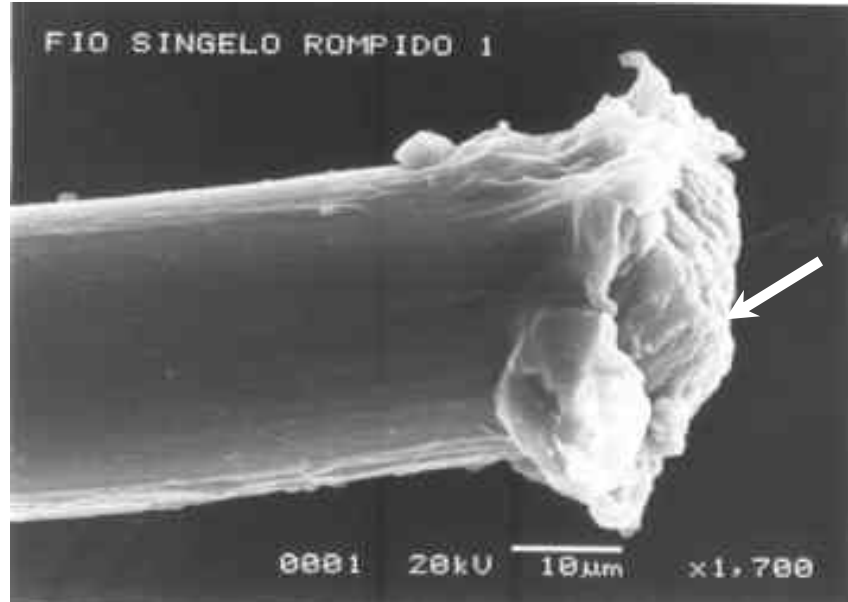

FIGURA 145. Filamentos de náilon singelos e rompidos (1700 x)

Nas Figuras 143 a 145 são mostradas as faces de fratura do tipo dúctil com pequenas variações nas suas secções para os filamentos de náilon tipo singelos e rompidos. Na figura 142 é mostrada a região de contaminação acentuada e na Figura 146 são mostrados veios de deformação plástica. 
Nas Figuras 147 a 152 são mostrados os perfis de fratura para os filamentos de náilon do tipo torcidos e rompidos.

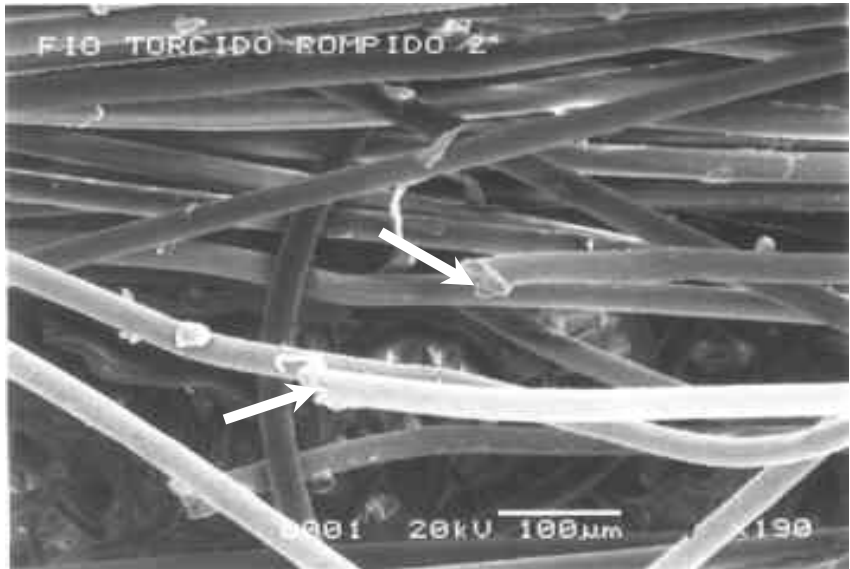

FIGURA 147. Filamentos de náilon torcidos e rompidos (190 x)

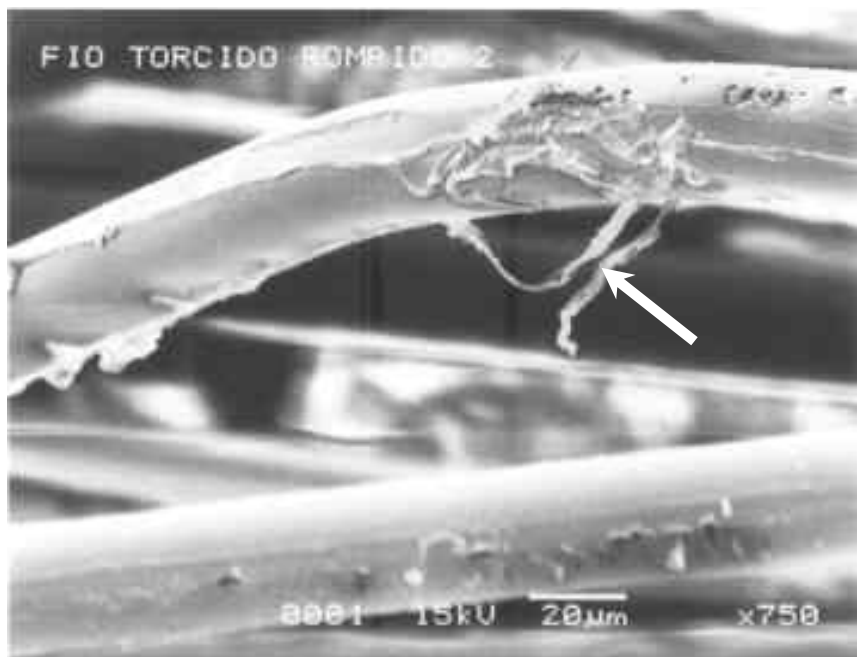

FIGURA 149. Filamentos de náilon torcidos e rompidos (750 x)

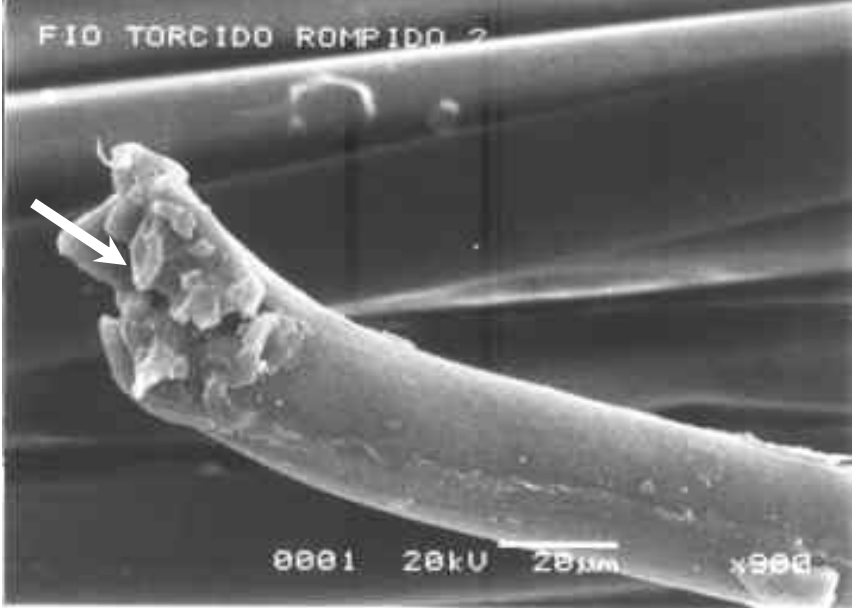

FIGURA 151. Filamentos de náilon torcidos e rompidos (900 x)

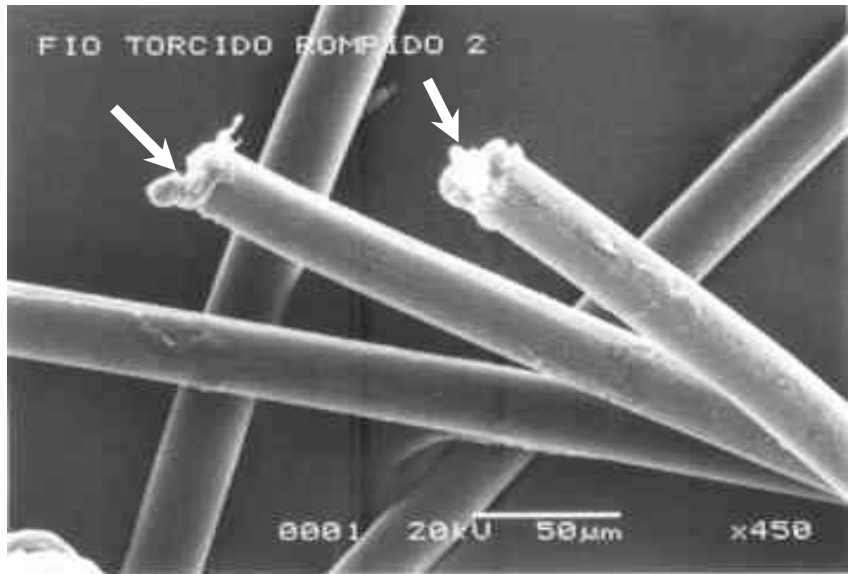

FIGURA 148. Filamentos de náilon torcidos e rompidos (450 x)

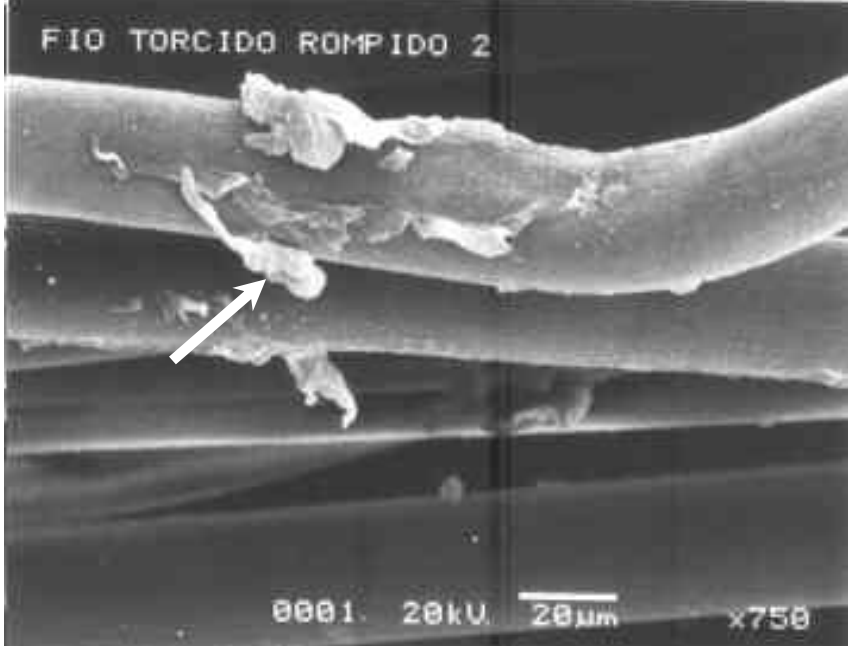

FIGURA 150. Filamentos de náilon torcidos e rompidos (750 x)

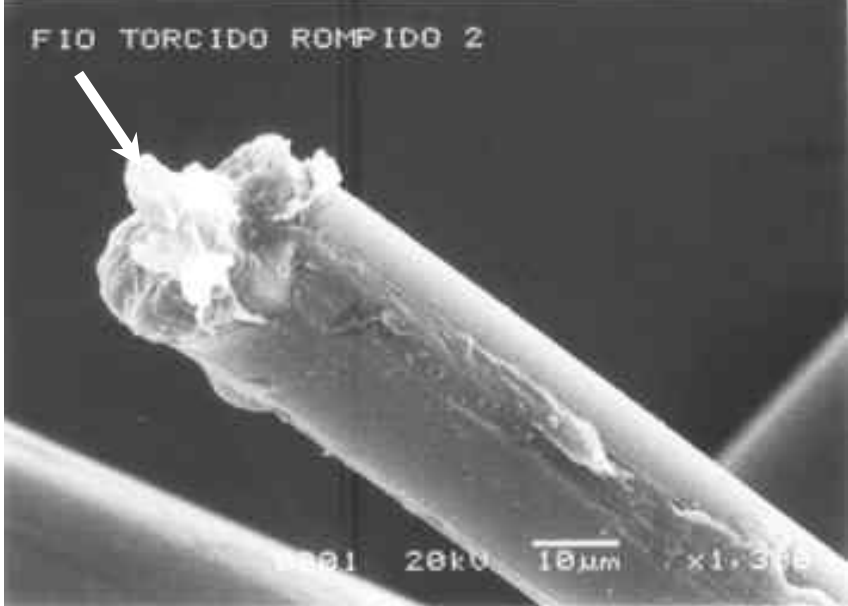

FIGURA 152. Filamentos de náilon torcidos e rompidos (1300 x) Os filamentos de náilon tipo torcidos e rompidos apresentam as faces de

fratura do tipo multiaxial com pontos de descamação nas Figuras 149 e 150 . Na figura 147 é mostrada uma região com o perfil de fratura heterogêneo para os filamentos da fibra. 
Nas Figuras 153 a 158 são mostrados os perfis de fratura para os filamentos de náilon do tipo construídos e rompidos.

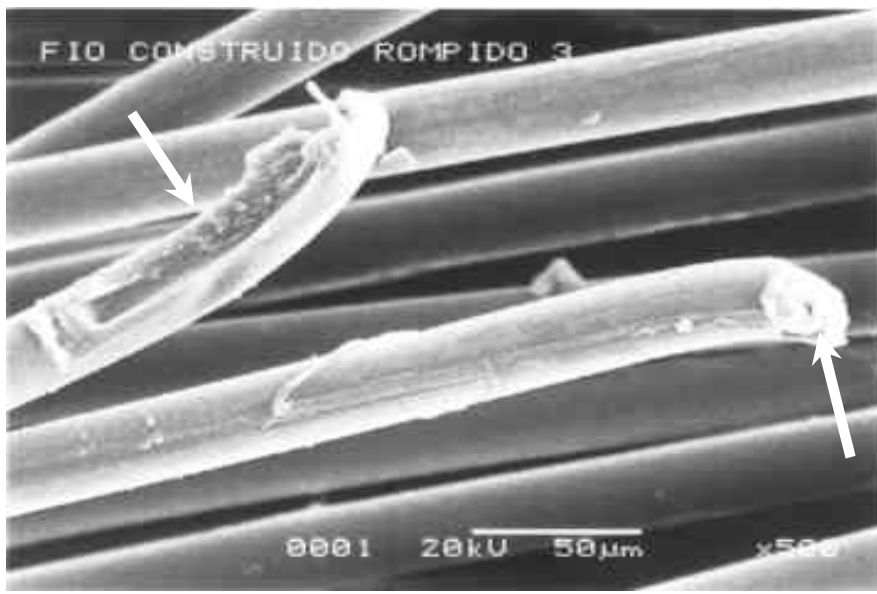

FIGURA 153. Filamentos de náilon construídos e rompidos (500 x) FIO CONSTRUIDO ROMPIDO 3

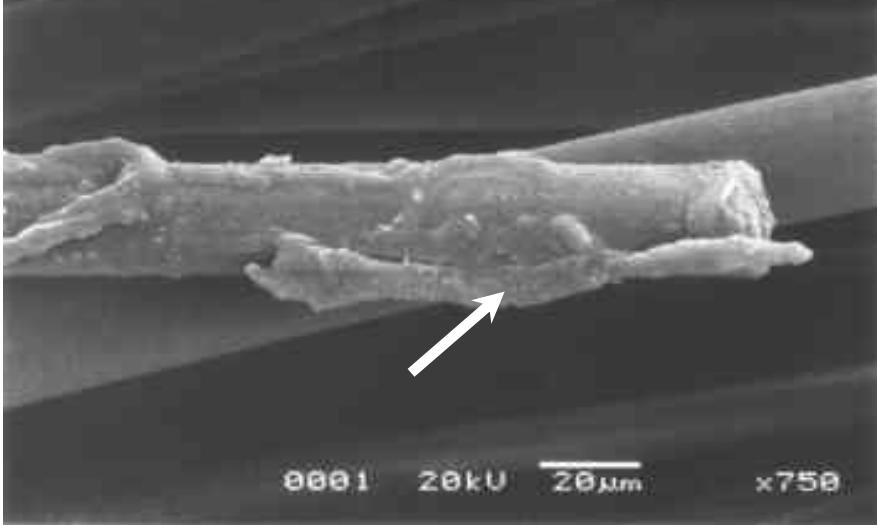

FIGURA 155. Filamentos de náilon construídos e rompidos (750 x)

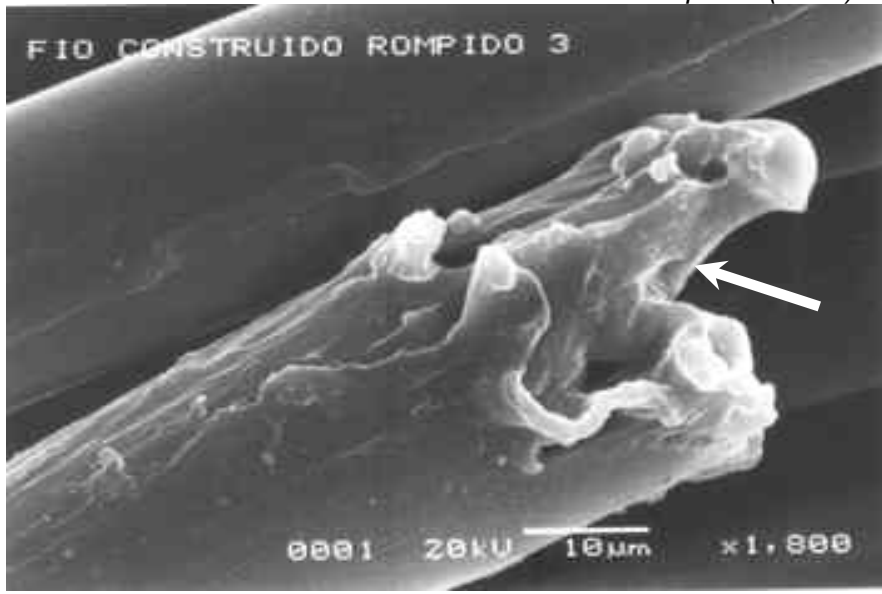

FIGURA 157. Filamentos de náilon construídos e rompidos (1000x)

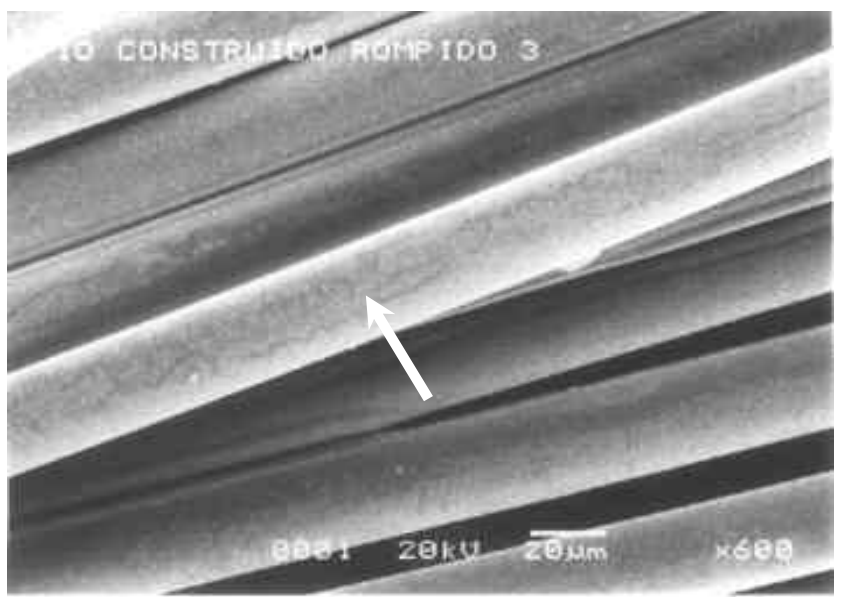

FIGURA 154. Filamentos de náilon construídos e rompidos (600 x)

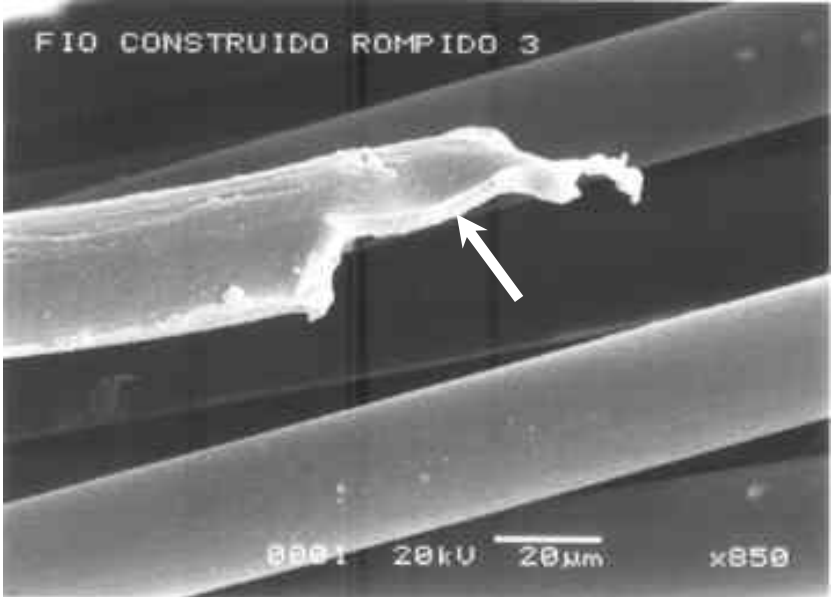

FIGURA 156. Filamentos de náilon construídos e rompidos (850 x)
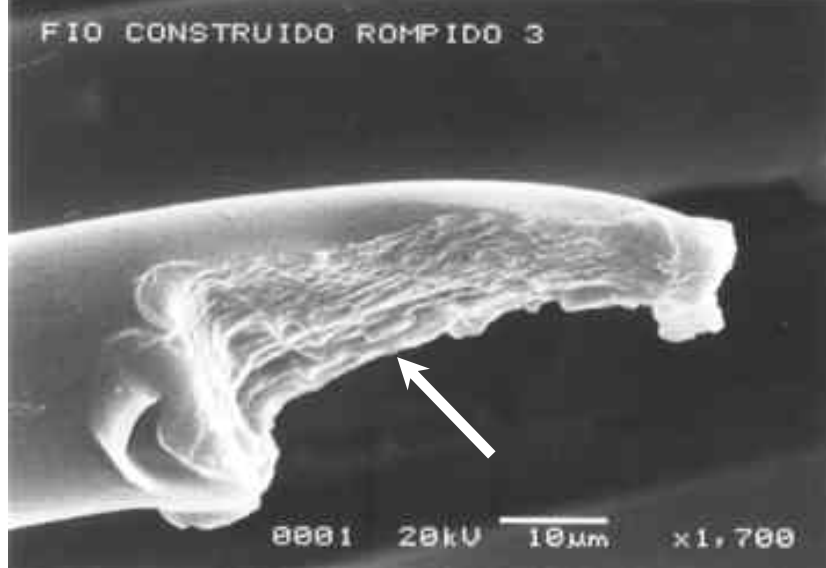

FIGURA 158. Filamentos de náilon construídos e rompidos (1700x) Os filamentos de náilon tipo construídos e rompidos apresentam uma mesma face de fratura multiaxial com pontos de descamação na Figura 155, porém, a deformação plástica é mais acentuada. 
Nas Figuras 159 a 163 são mostrados os perfis de fratura para os filamentos de náilon do tipo dipados e rompidos.

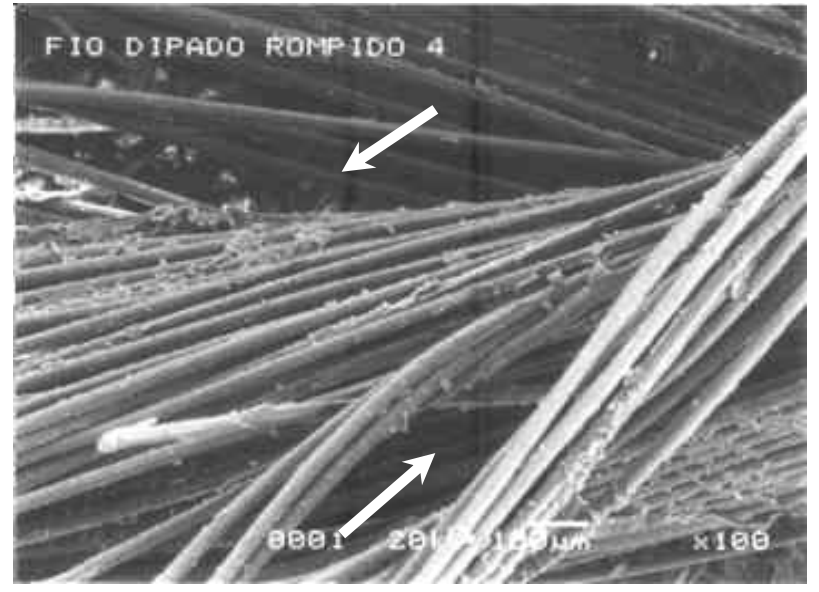

FIGURA 159. Filamentos de náilon dipados e rompidos (100x)

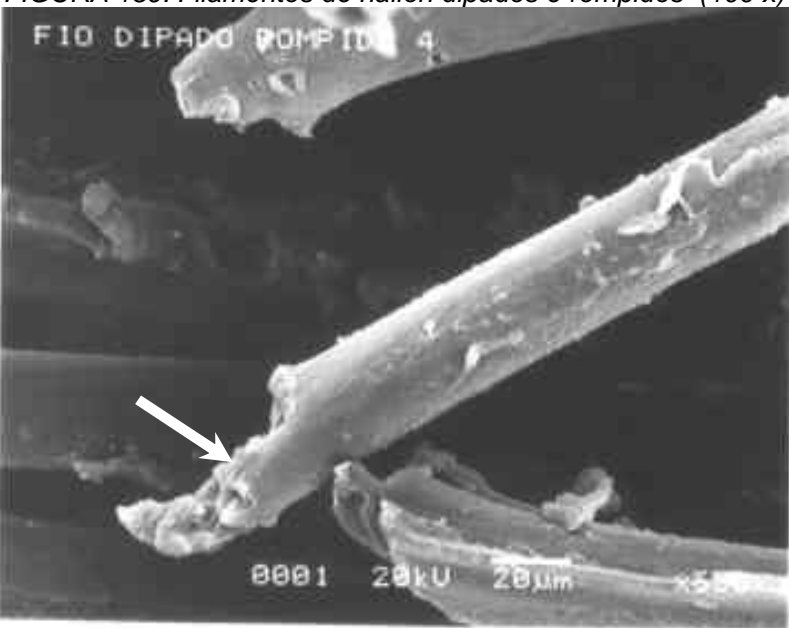

FIGURA 161. Filamentos de náilon dipados e rompidos (600 x)

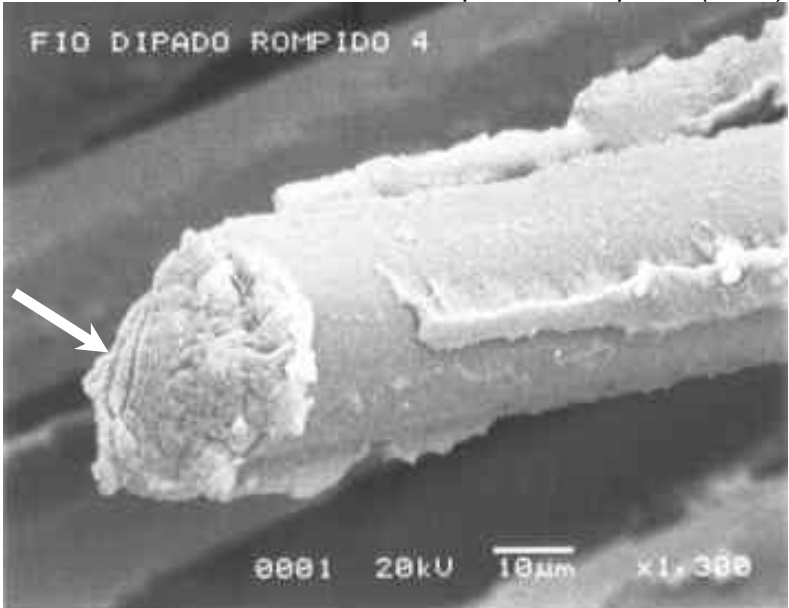

FIGURA 163. Filamentos de náilon dipados e rompidos (1300x)

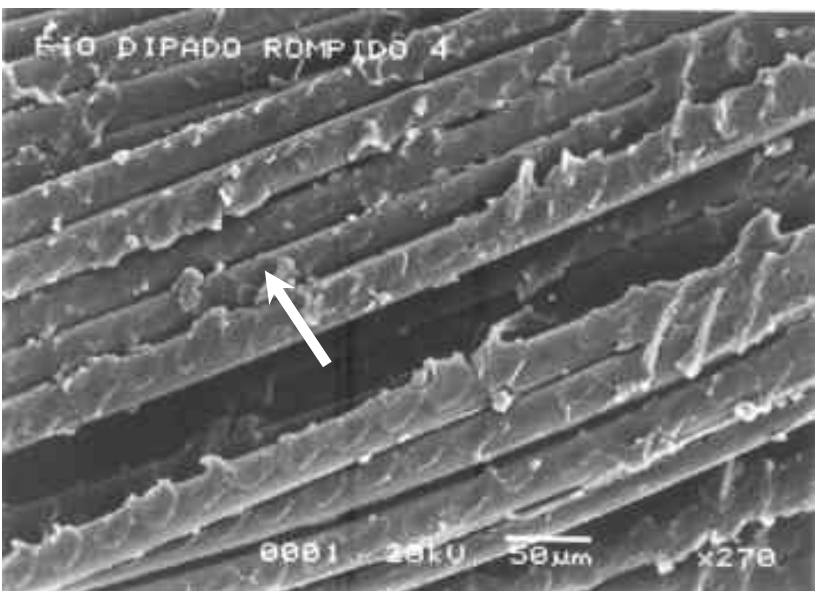

FIGURA 160. Filamentos de náilon dipados e rompidos $(270 x)$

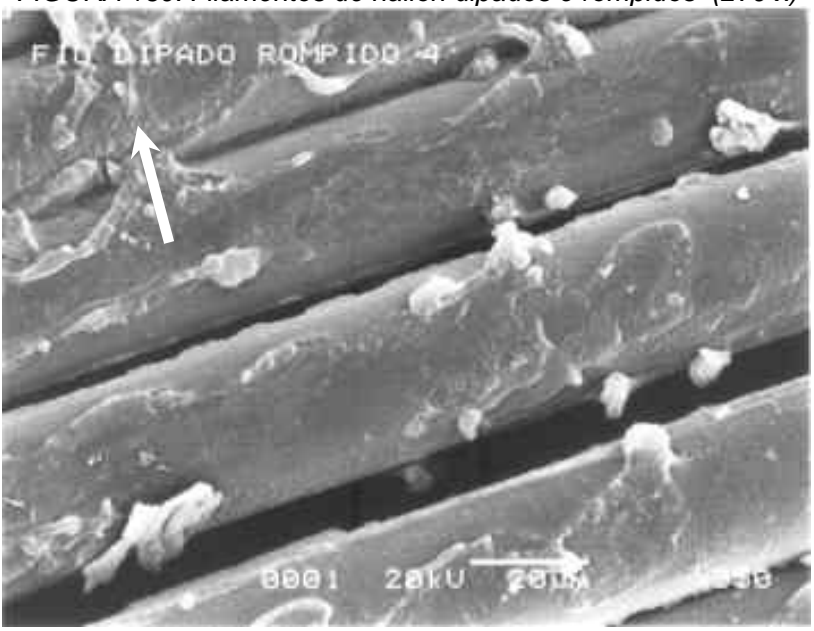

FIGURA 162. Filamentos de náilon dipados e rompidos (950x)

Os filamentos de náilon tipo dipados e rompidos apresentam as faces de fratura multiaxial nas Figuras 161 e 163, com pontos de impregnação da solução de dipagem nas Figuras 160 e 162 e separação acentuada dos filamentos conforme é mostrado na Figura 159. 
Nas Figuras 164 a 168 são mostrados os perfis de fratura para os filamentos de náilon do tipo vulcanizados e rompidos.

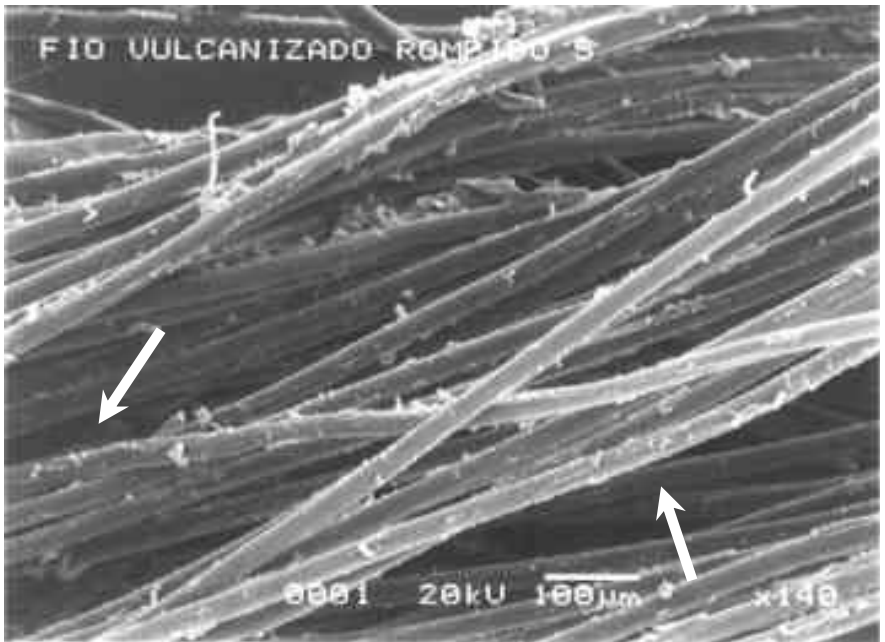

FIGURA 164. Filamentos de náilon vulcanizados e rompidos $(140 x)$

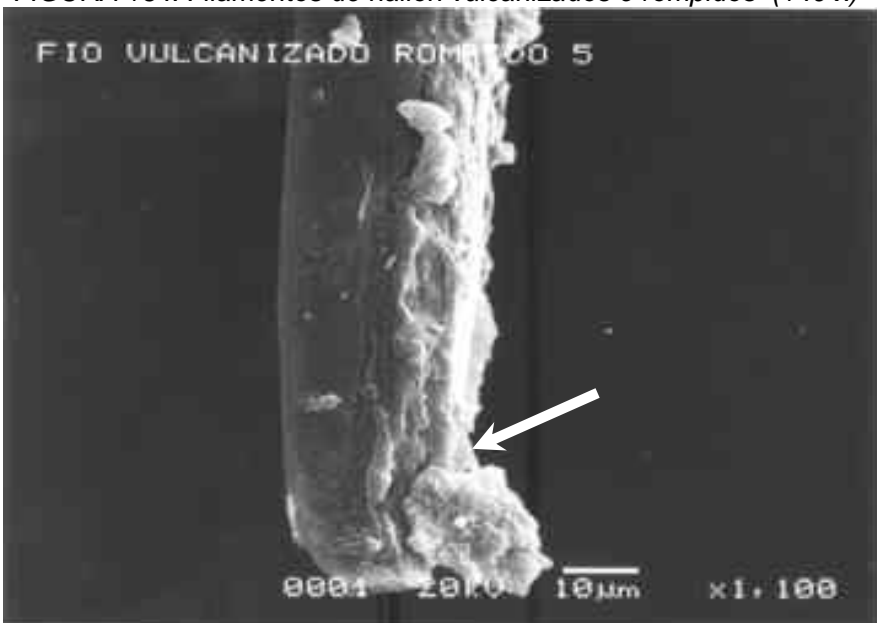

FIGURA 166. Filamentos de náilon vulcanizados e rompidos (1100 x)

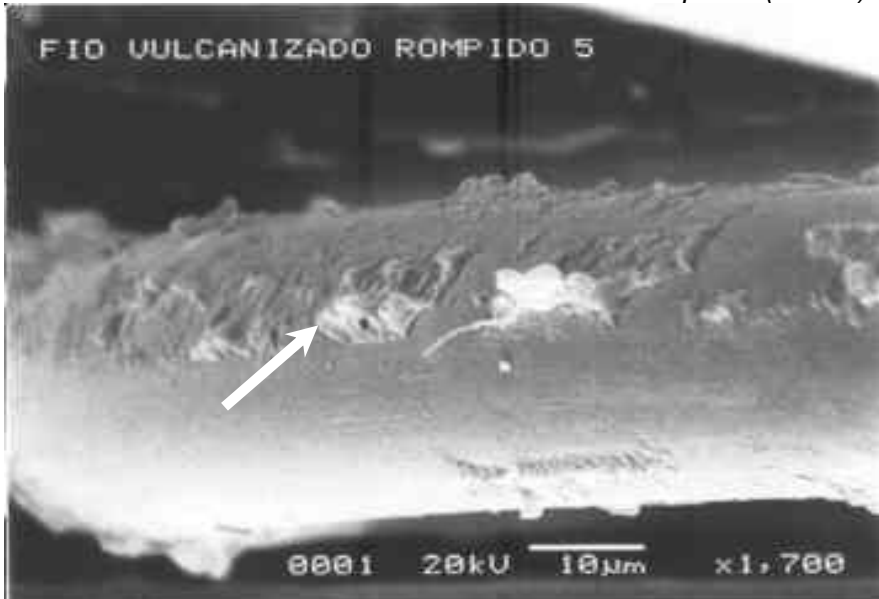

FIGURA 168. Filamentos de náilon vulcanizados e rompidos (1700x)

Os filamentos de náilon tipo vulcanizados e rompidos apresentam uma mesma face de fratura multiaxial nas Figuras 166 e 167 com pequenos pontos de impregnação da solução de borracha nas Figuras 165 e 168 e separação acentuada dos filamentos, conforme é mostrada na Figura 164. 
Nas Figuras 169 a 174 são mostrados os perfis dos filamentos de poliéster do tipo singelos sem rompimento.

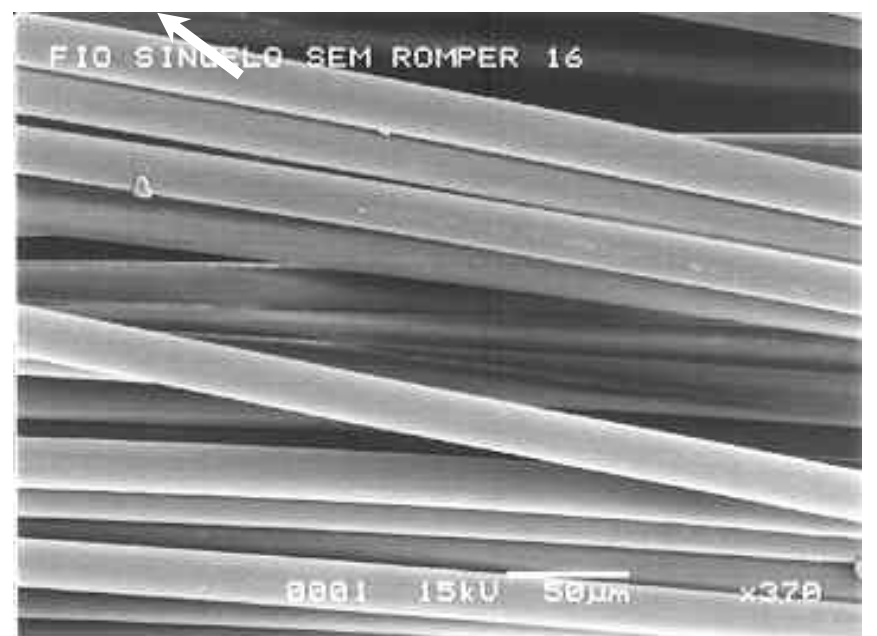

FIGURA 169. Filamentos de poliéster singelos sem romper (370 x)

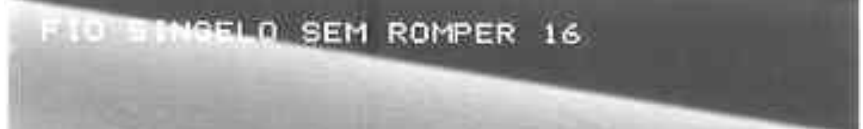

FIGURA 171. Filam?ntos de poliéster singelos sem romper (1300 x)

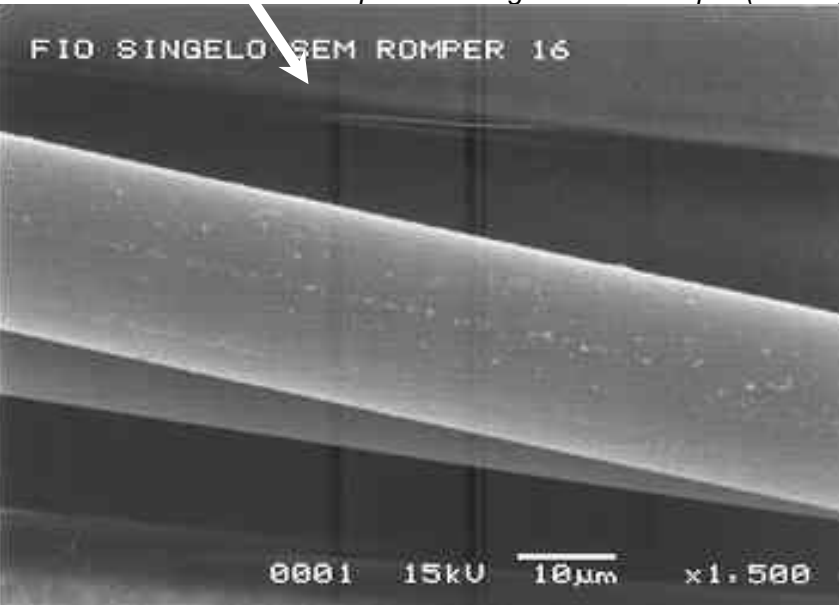

FIGURA 173. Filamentos de poliéster singelos sem romper (1500 x)
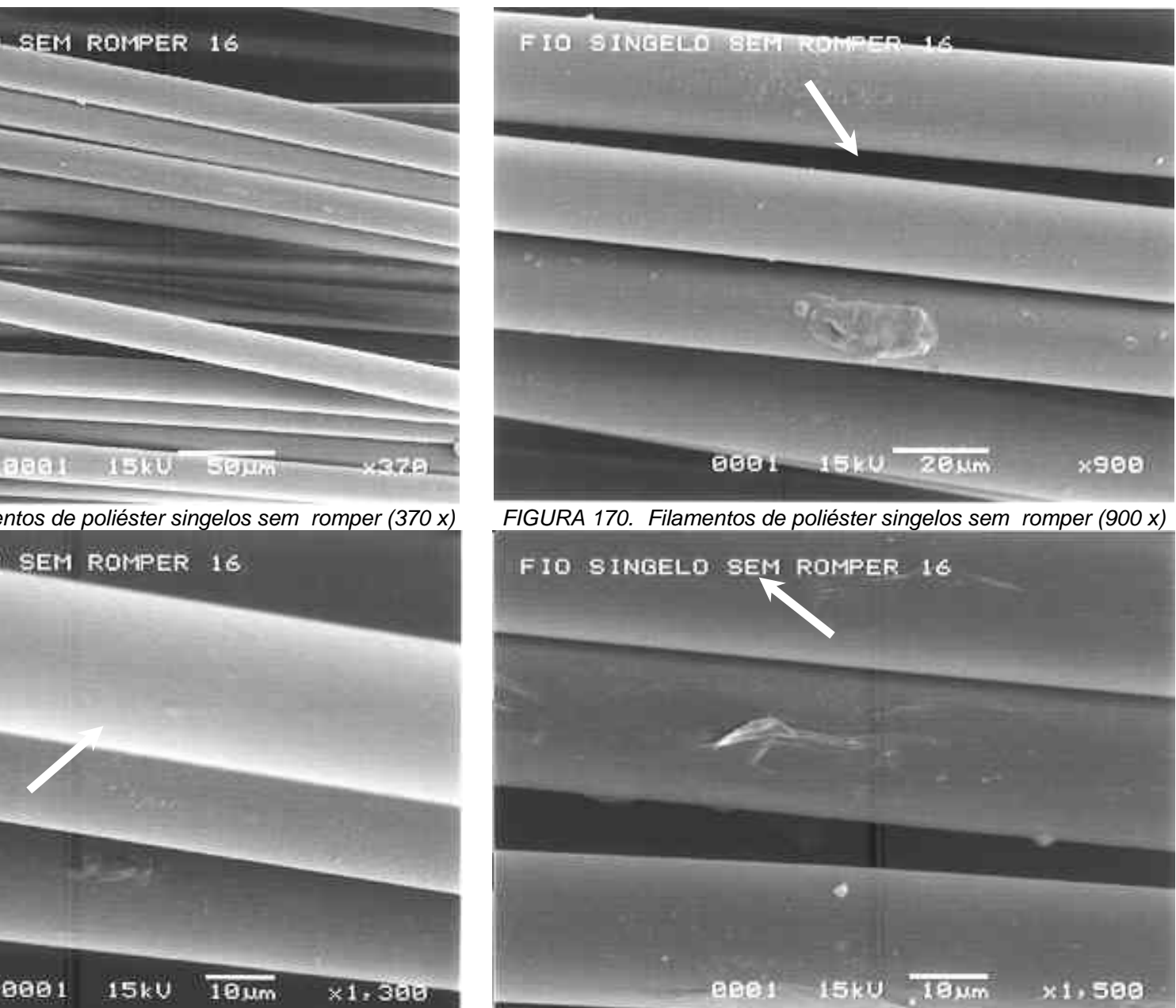

FIGURA 170. Filamentos de poliéster singelos sem romper (900 x)

FID SINBELO SEM ROMPER 16

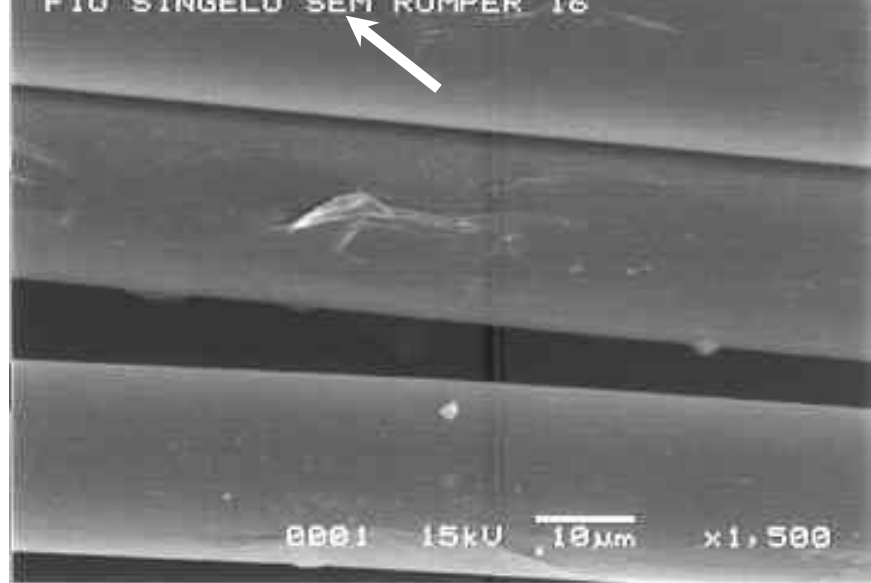

FIGURA 172. Filamentos de poliéster singelos sem romper (1500x)

FIO SINGELO SEM ROMPER. 16

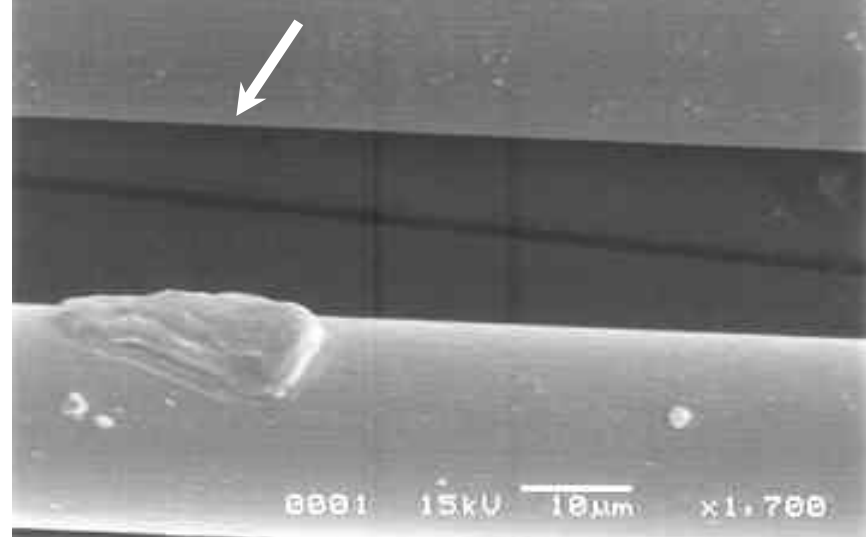

FIGURA 174. Filamentos de poliéster singelos sem romper (1700x) Pode ser observado nas superfícies dos filamentos de poliéster tipo singelos sinais de contaminação acentuada por partículas sem deformação aparente. 
Nas Figuras 175 a 180 são mostrados os perfis dos filamentos de poliéster do tipo torcidos sem rompimento.

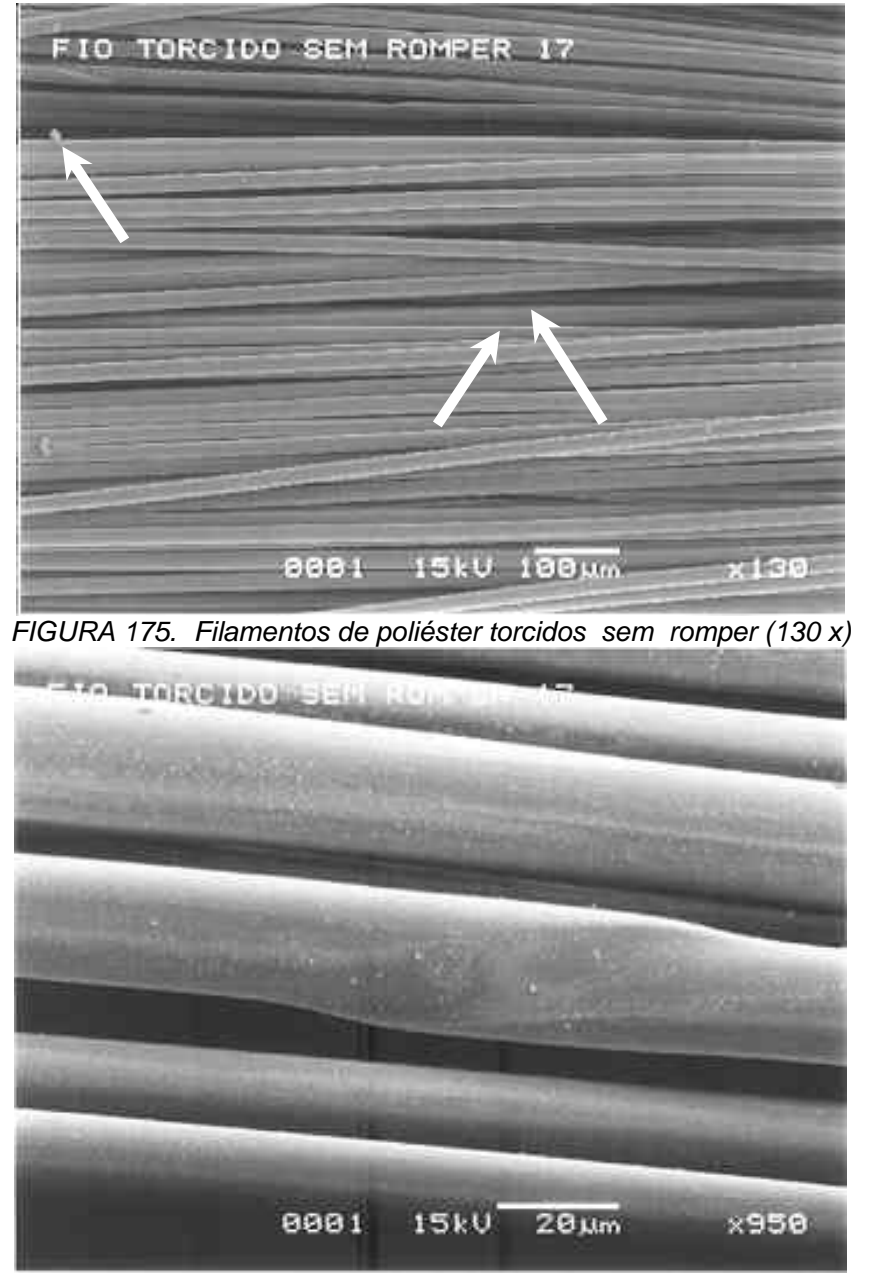

FIGURA 177. Filamentos de poliéster torcidos sem romper (950 x)

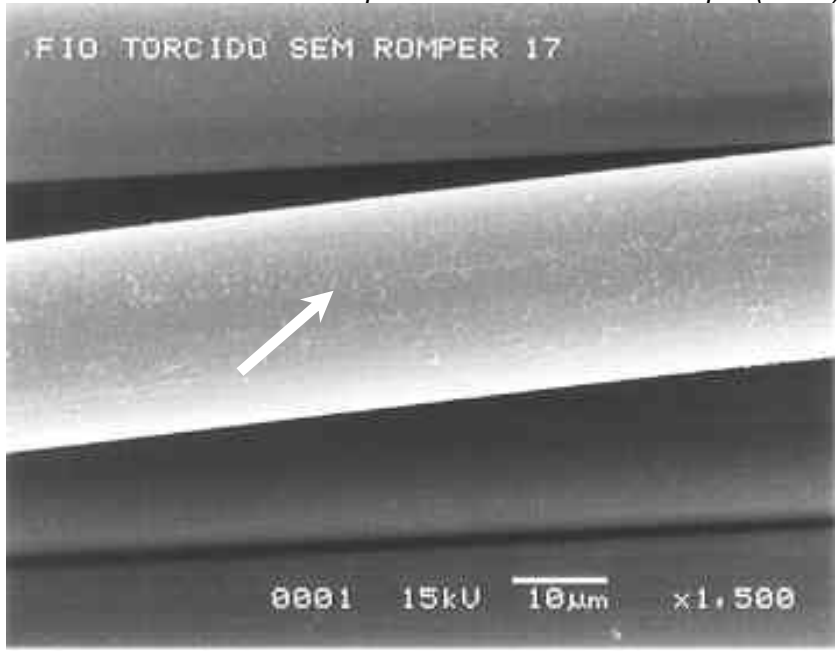

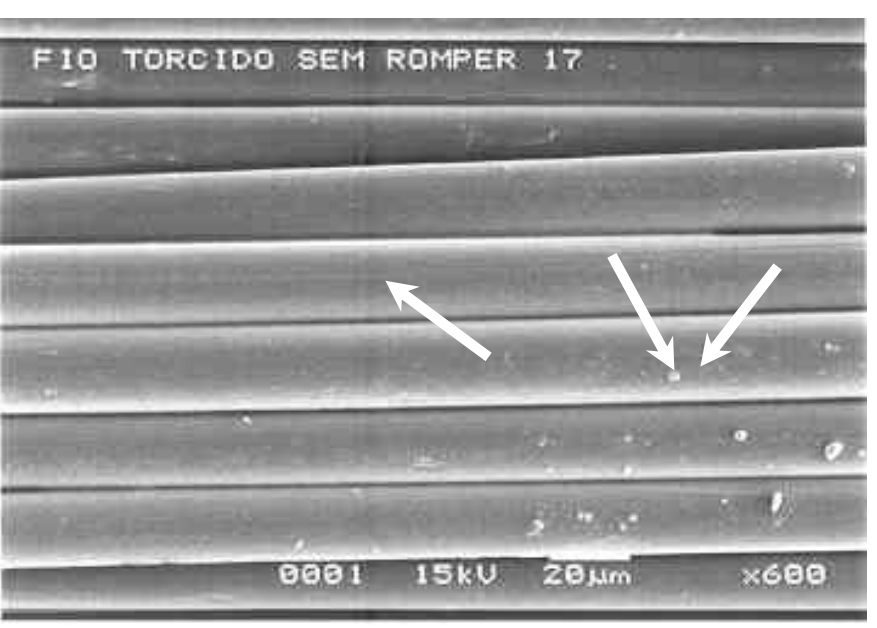

FIGURA 176. Filamentos de poliéster torcidos sem romper (600 x)

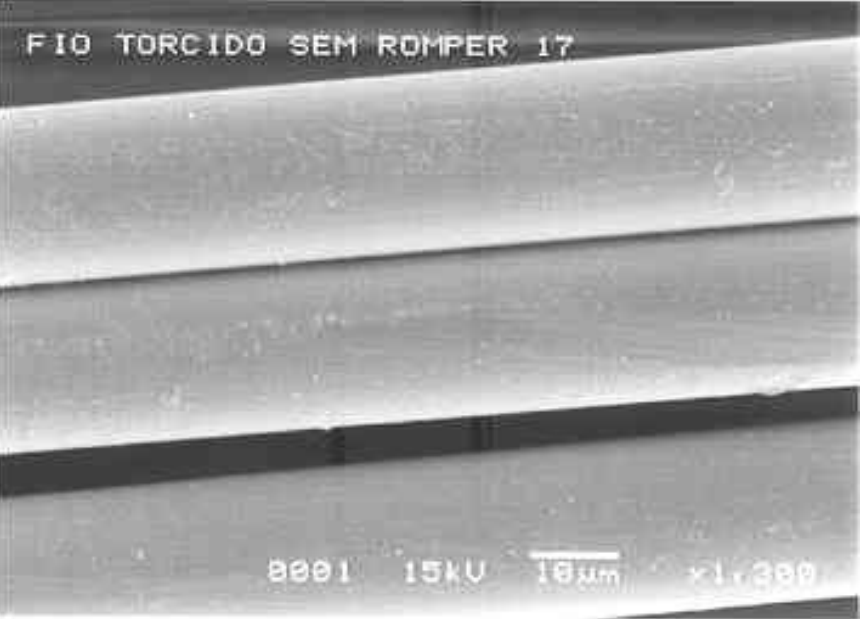

FIGURA 178. Filamentos de poliéster torcidos sem romper $(1300 x)$
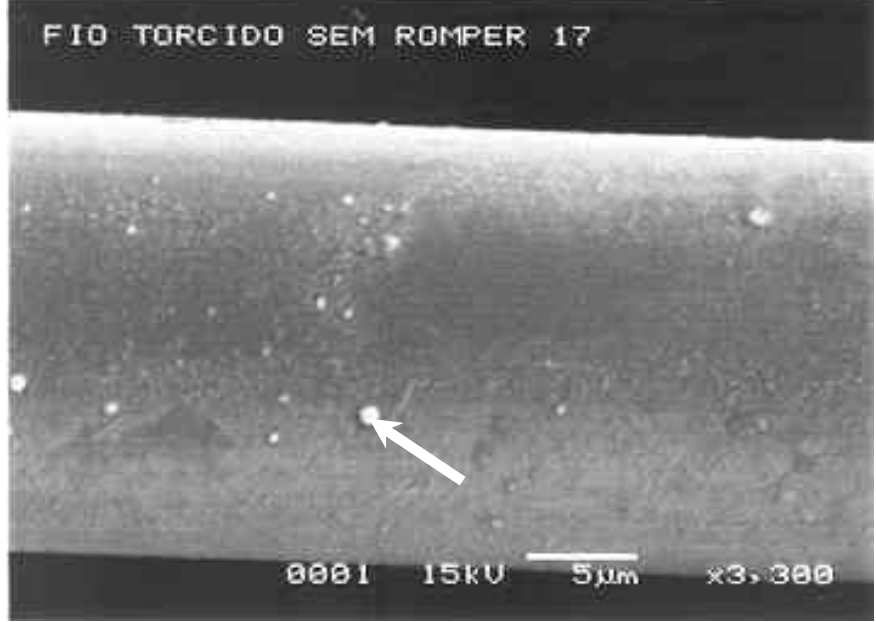

FIGURA 179. Filamentos de poliéster torcidos sem romper (1500x) FIGURA 180. Filamentos de poliéster torcidos sem romper (3300 $x$ ) Pode ser observado na superfície dos filamentos de poliéster tipo torcidos sinais de contaminações nas Figuras 175, 176, 179 e 180. Na Figura 177 é mostrada a deformação plástica e na Figura 178 são mostradas pequenas estrias longitudinais. 
Nas Figuras 181 a 186 são mostrados os perfis das fibras de poliéster do tipo construídos sem rompimento.

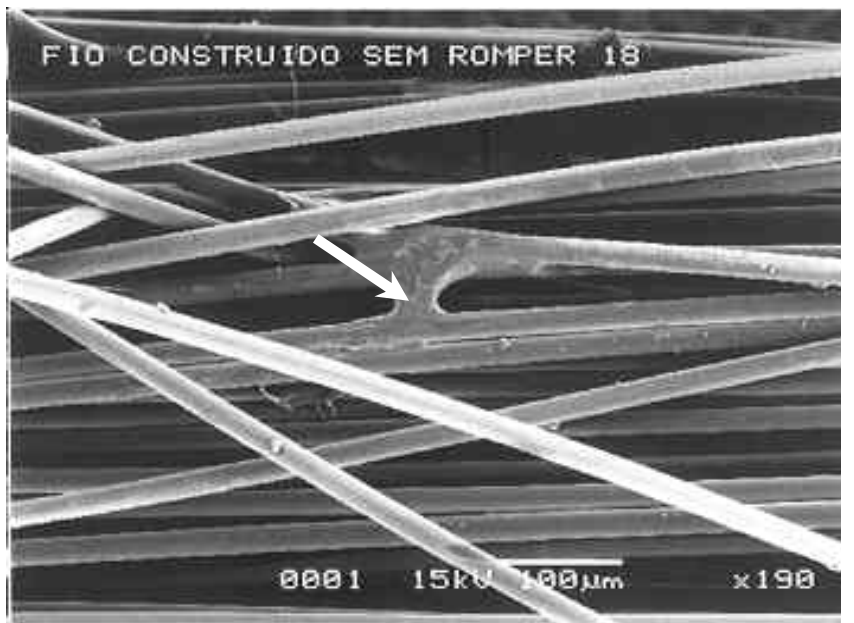

FIGURA 181. Filamentos de poliéster construídos sem romper (190 x) FIO EONSTRUIDO SEM ROMPER 18

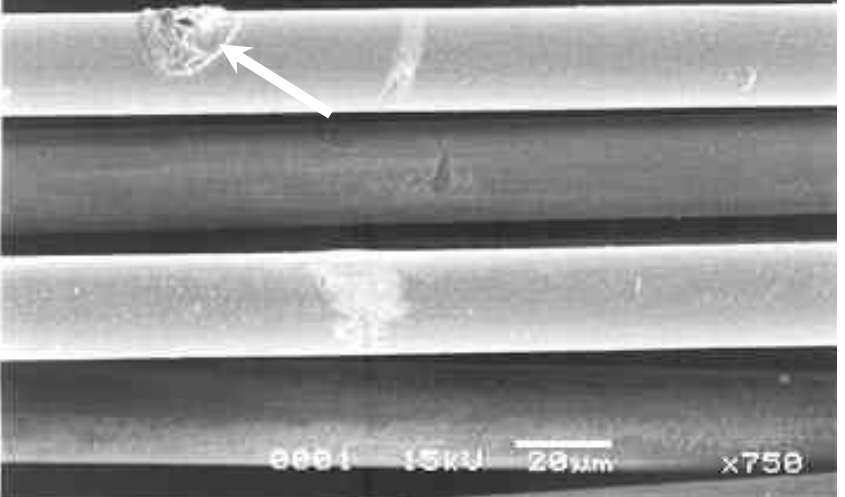

FIGURA 183. Filamentos de poliéster construídos sem romper (750 x)

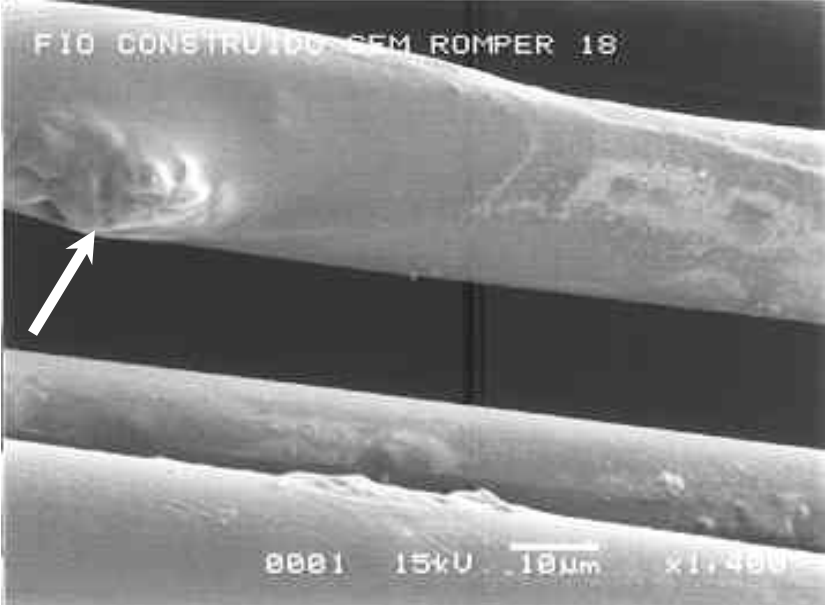

FIGURA 185. Filamentos de poliéster construídos sem romper $(1400 \mathrm{x})$

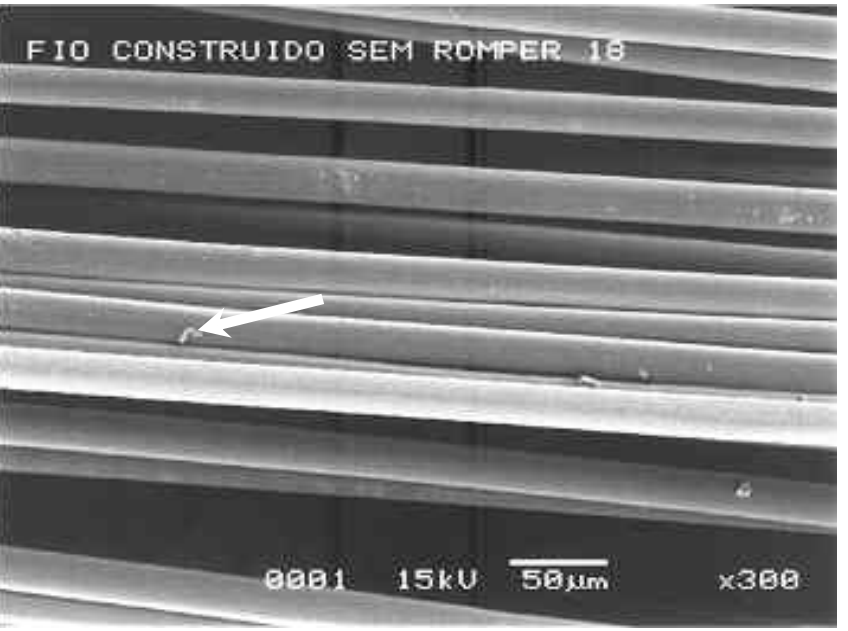

FIGURA 182. Filamentos de poliéster construídos sem romper (300 x) FIO EDNSTRUIDO SEM RDMRER 18

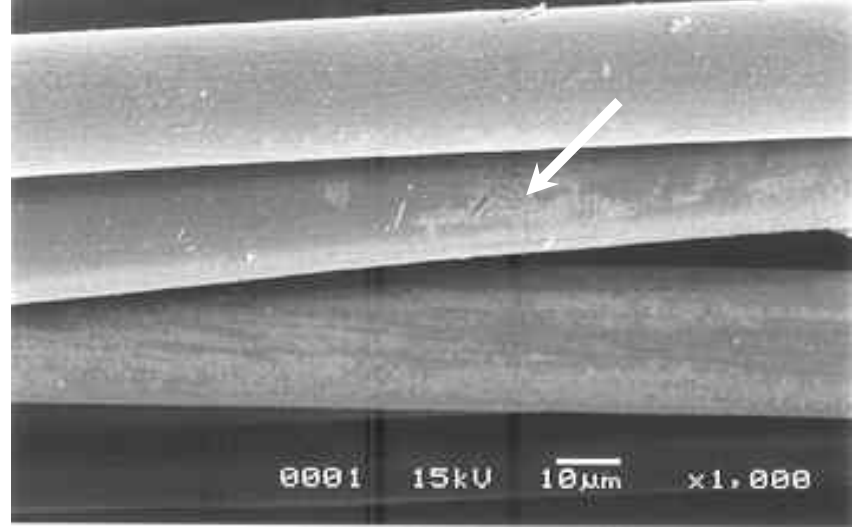

FIGURA 184. Filamentos de poliéster construídos sem romper (1000x)

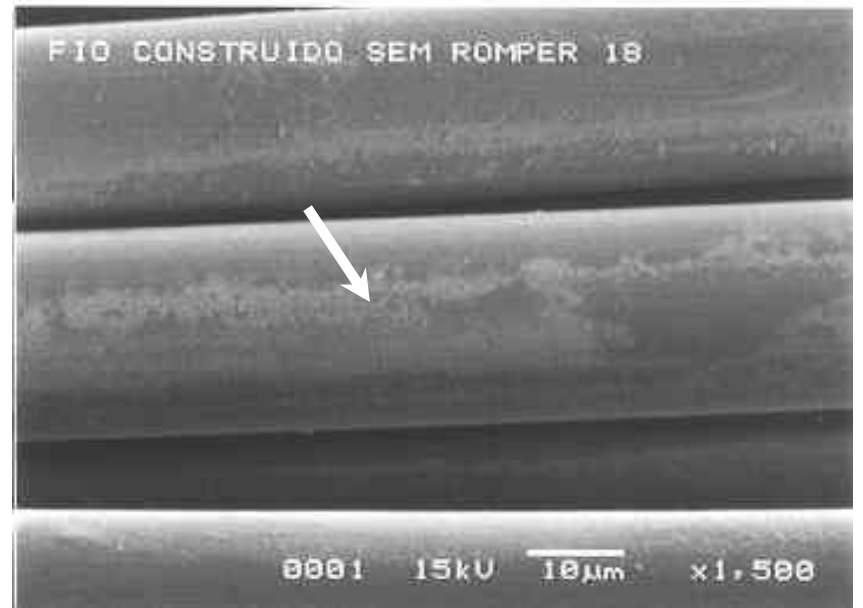

FIGURA 186. Filamentos de poliéster construídos sem romper $(1500$ x)

Pode ser observado na superfície dos filamentos de náilon tipo construídos sinais de contaminação nas Figuras 181 a 183 e manchas superficiais nas Figuras 184 e 186. Na Figura 185 é mostrado o filamento com intensa deformação plástica. 
Nas Figuras 187 a 192 são mostrados os perfis dos filamentos de poliéster do tipo dipados sem rompimento.
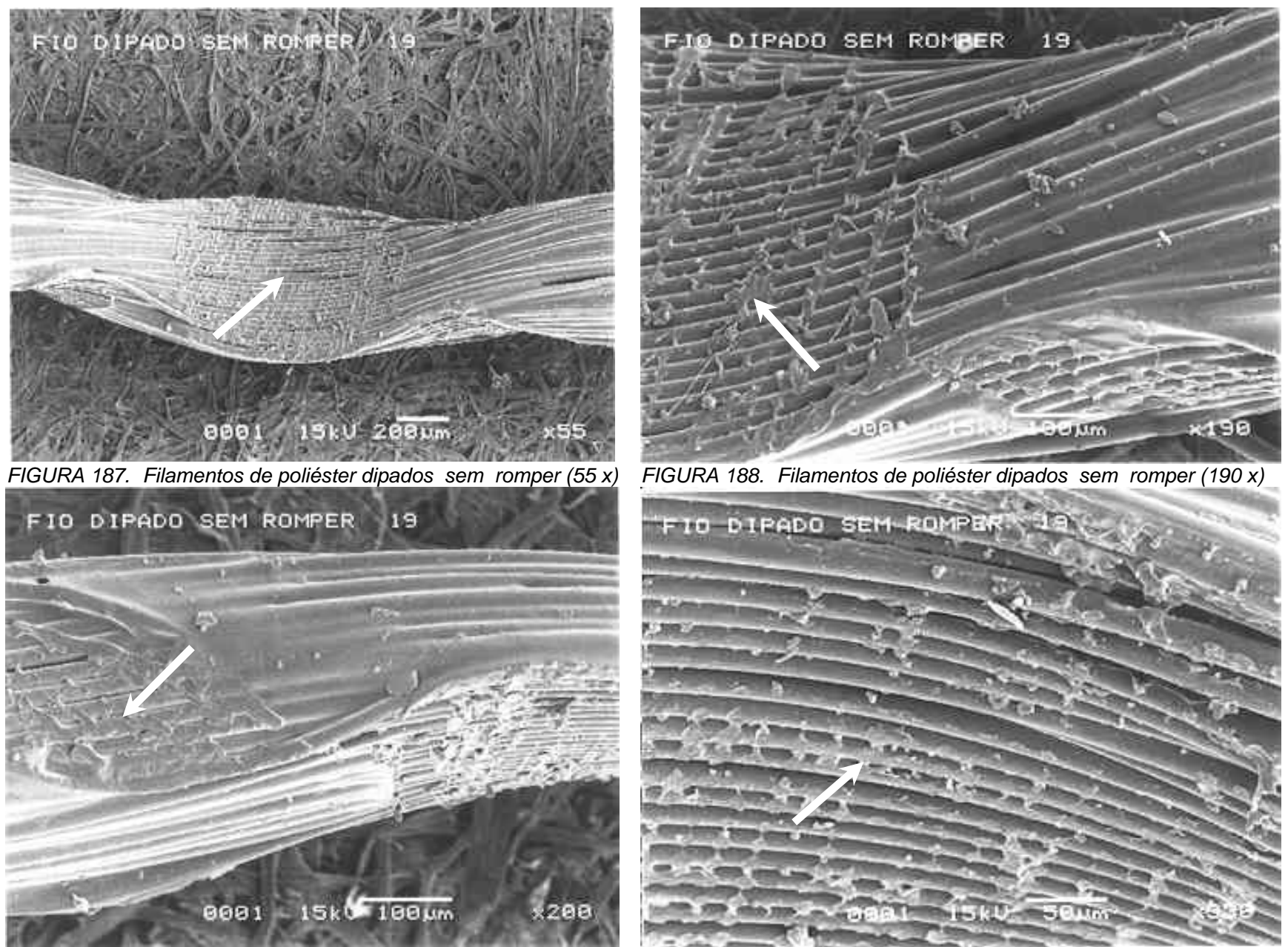

FIGURA 189. Filamentos de poliéster dipados sem romper (200 x)
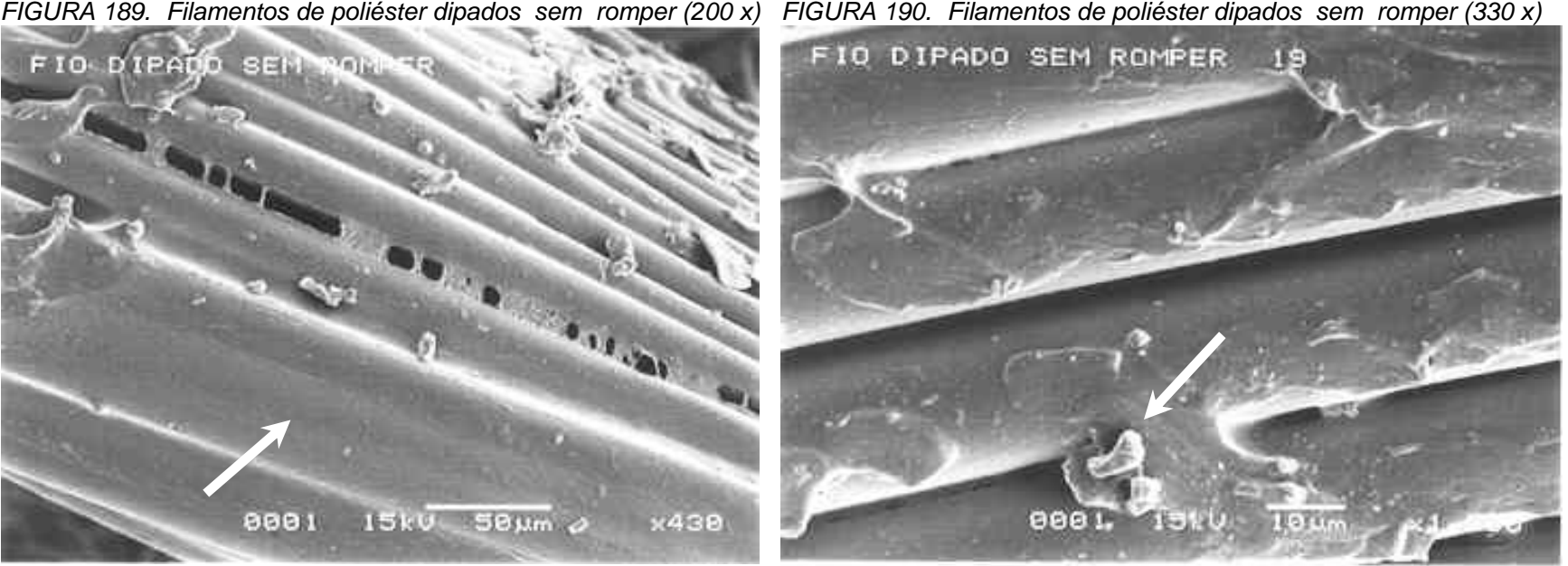

FIGURA 191. Filamentos de poliéster dipados sem romper $(430 x)$

FIGURA 192. Filamentos de poliéster dipados sem romper $(1300 x)$

Pode ser observado na superfície dos filamentos de poliéster tipo dipados marcas de contato da fibra da trama nas Figuras 187 a 190 com falhas na impregnação da solução de dipagem devido ao contato. É possível observar intensa impregnação da solução de dipagem nas Figuras 191 e 192. 
Nas Figuras 193 a 197 são mostrados os perfis dos filamentos de poliéster do tipo vulcanizados sem rompimento.
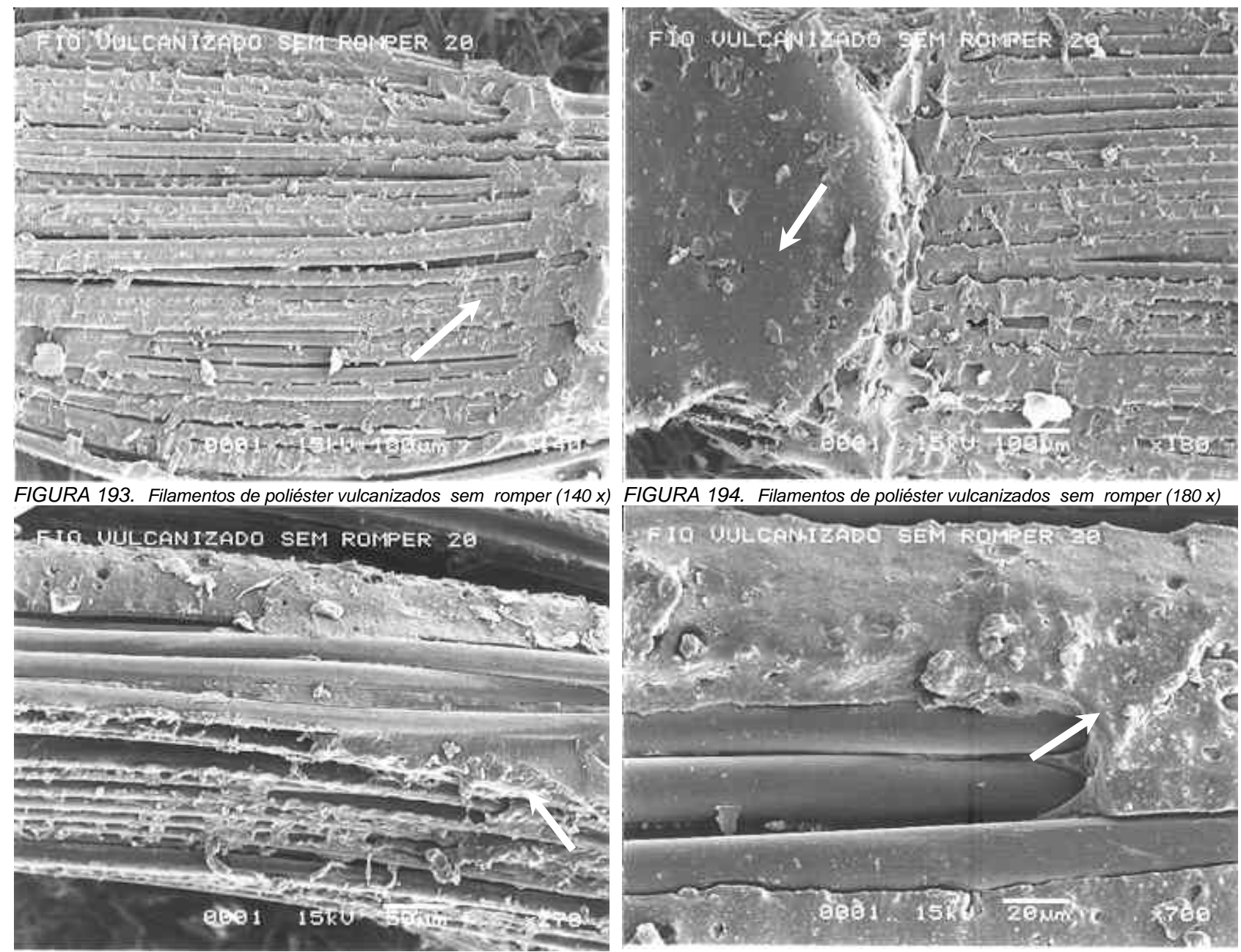

FIGURA 195. Filamentos de poliéster vulcanizados sem romper $(270 x)$

FIGURA 196. Filamentos de poliéster vulcanizados sem romper $(700 x)$

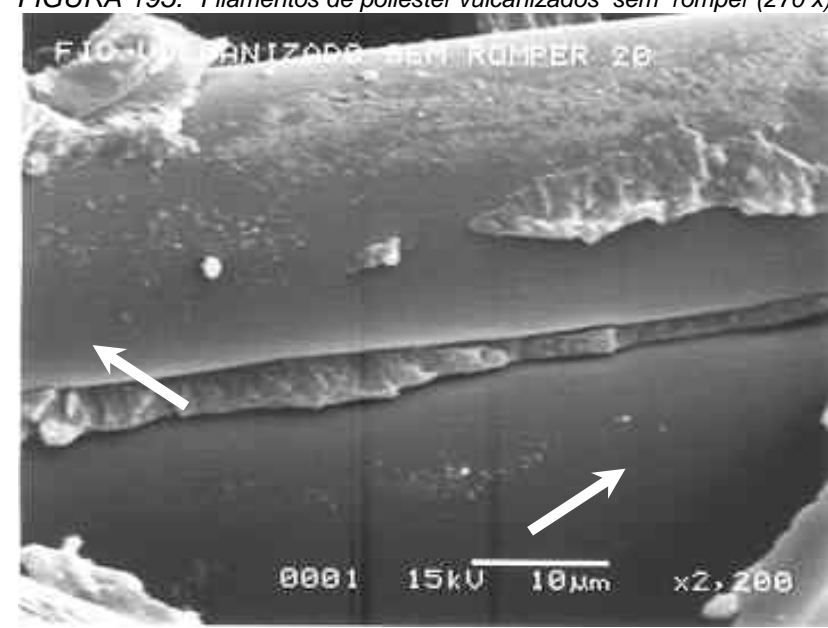

FIGURA 197. Filamentos de poliéster vulcanizados sem romper $(2200$ x)

Pode ser observado na superfície dos filamentos de poliéster tipo vulcanizados regiões de intensa impregnação na interface fibra-borracha nas Figuras 192 a 196. Na Figura 197 são mostradas regiões de menor índice de impregnação superficial nos filamentos. 
Nas Figuras 198 a 203 são mostrados os perfis de fratura para os filamentos de poliéster do tipo singelos e rompidos.

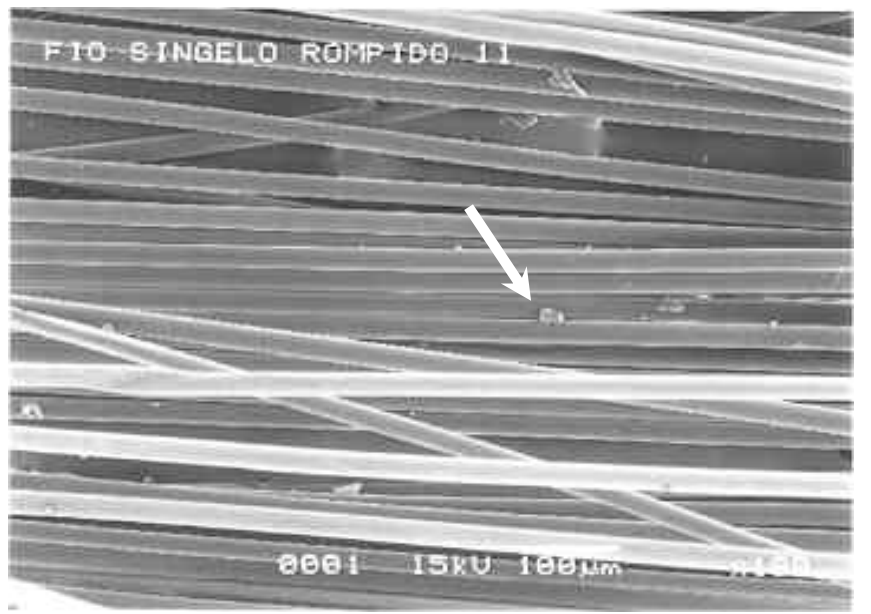

FIGURA 198. Filamentos de poliéster singelos e rompidos (180 x)

FIO SINGELO ROMPIDO 11
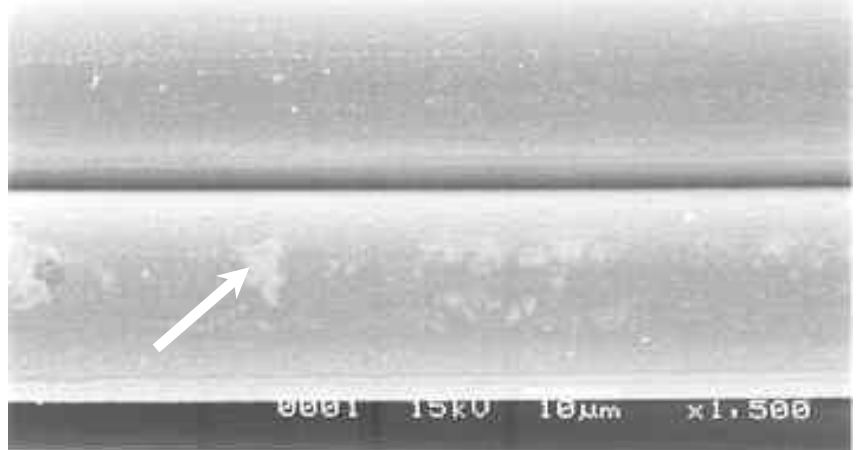

FIGURA 200. Filamentos de poliéster singelos e rompidos $(1500 \mathrm{x})$

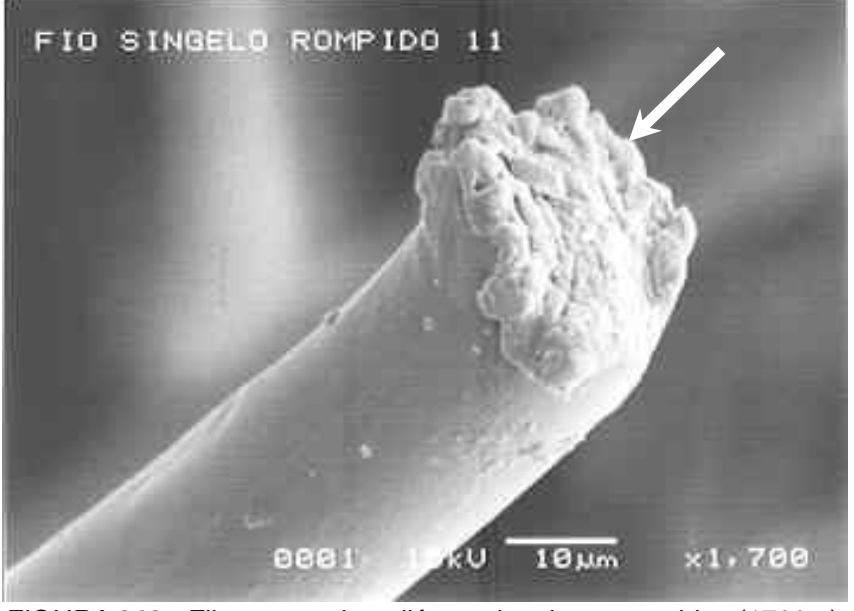

FIGURA 202. Filamentos de poliéster singelos e rompidos (1700 x)

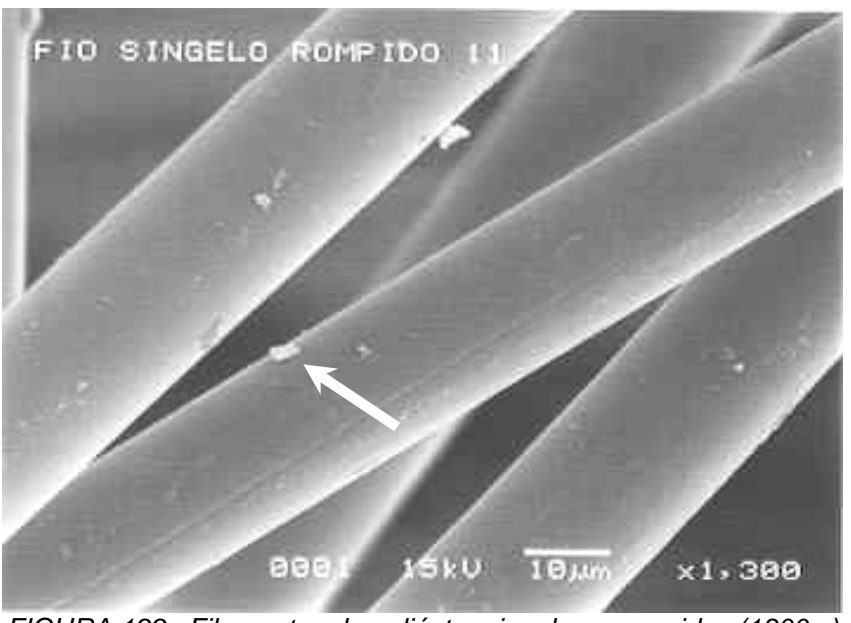

FIGURA 199. Filamentos de poliéster singelos e rompidos (1300 x)

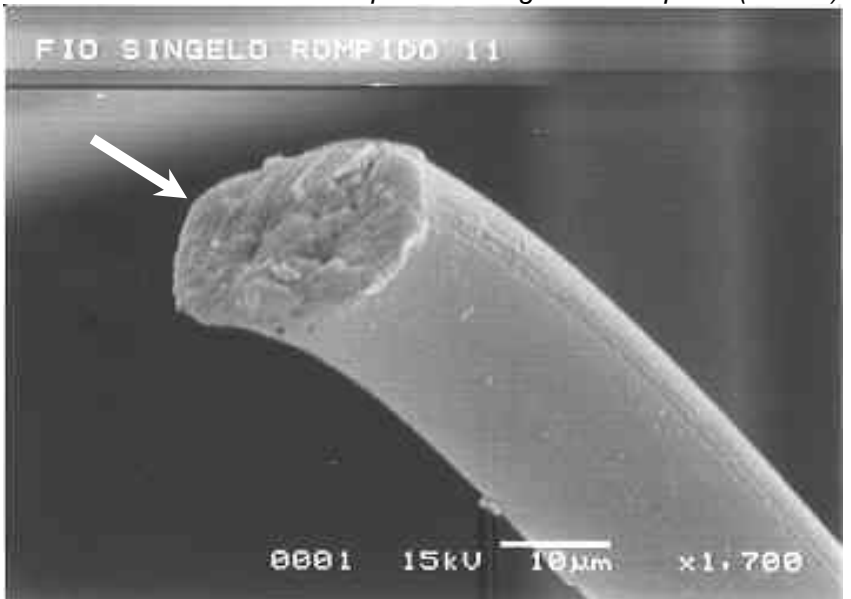

FIGURA 201. Filamentos de poliéster singelos e rompidos (1700 x)

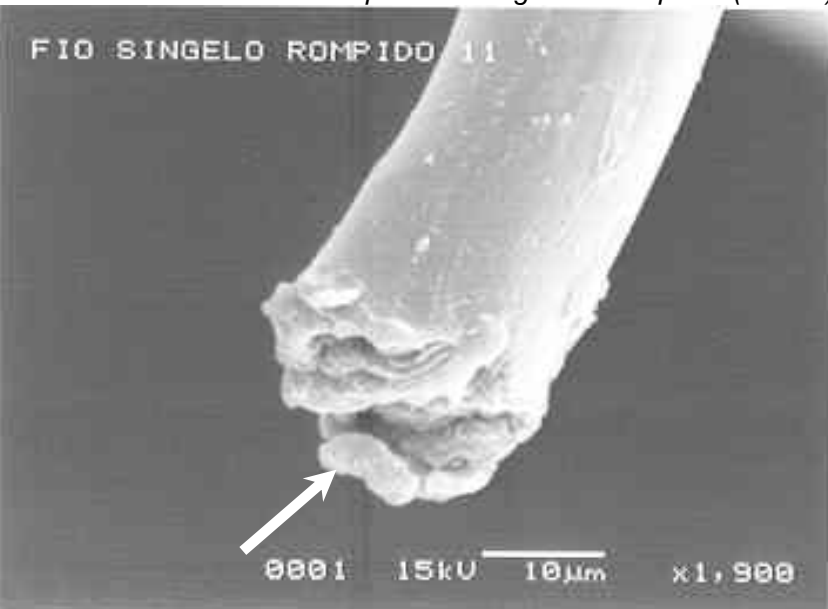

FIGURA 203. Filamentos de poliéster singelos e rompidos (1900 x) o singelos e rompidos apresentam uma secção de fratura do tipo dúctil com pequena variação na sua face nas Figuras 201 a 203. Nas Figuras 198 a 200 são mostrados sinais de intensa contaminação por partículas. 
Nas Figuras 204 a 209 são mostrados os perfis de fratura para os filamentos de poliéster do tipo torcidos e rompidos.

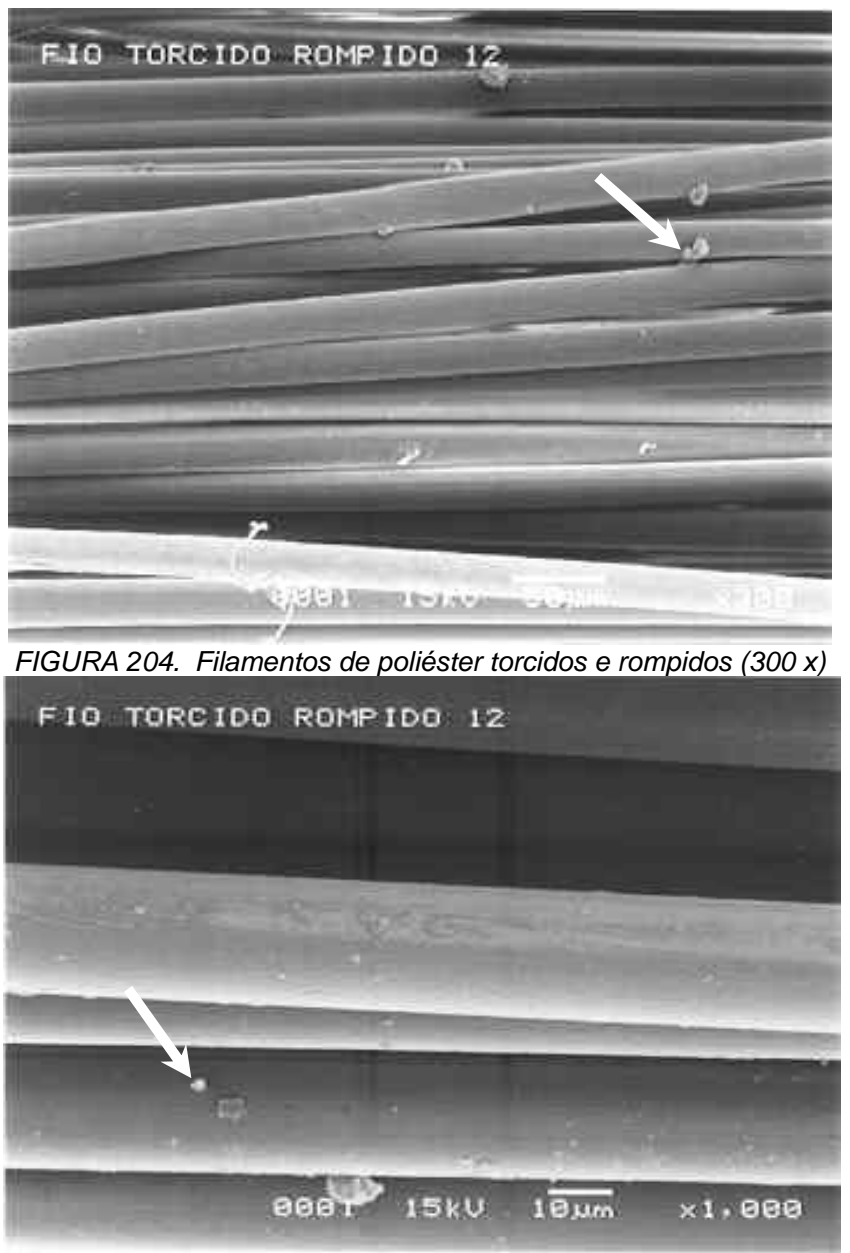

FIGURA 206. Filamentos de poliéster torcidos e rompidos (1000 x)

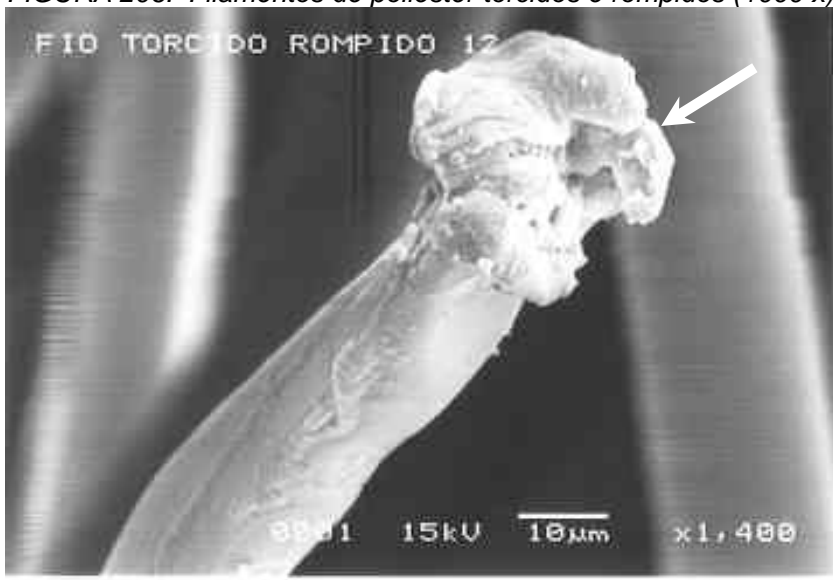

FIGURA 208. Filamentos de poliéster torcidos e rompidos $(1400 x)$

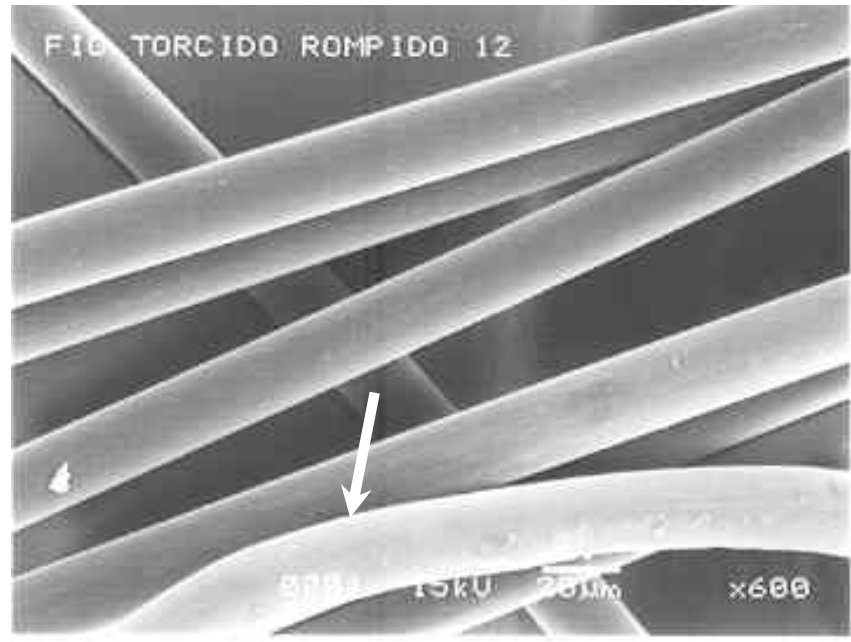

FIGURA 205. Filamentos de poliéster torcidos e rompidos (600 x)

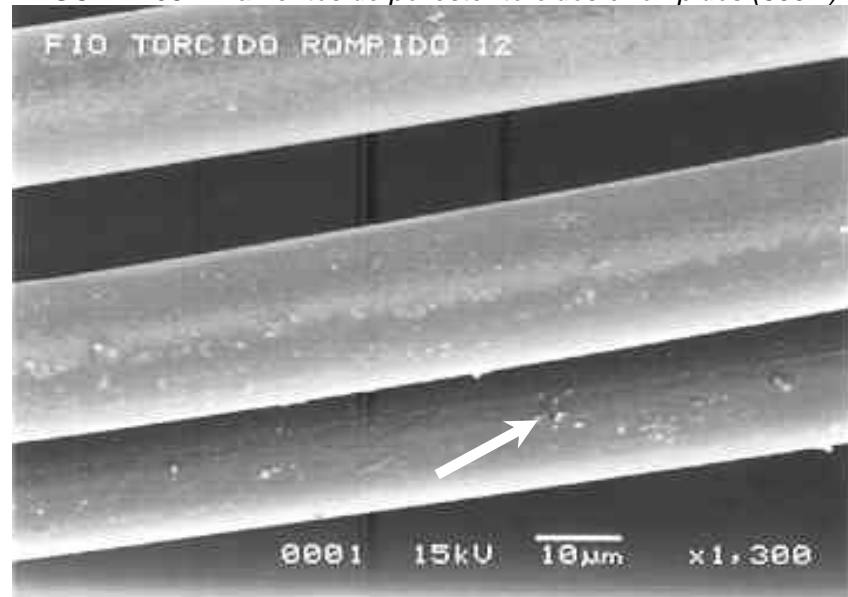

FIGURA 207. Filamentos de poliéster torcidos e rompidos (1300 x)

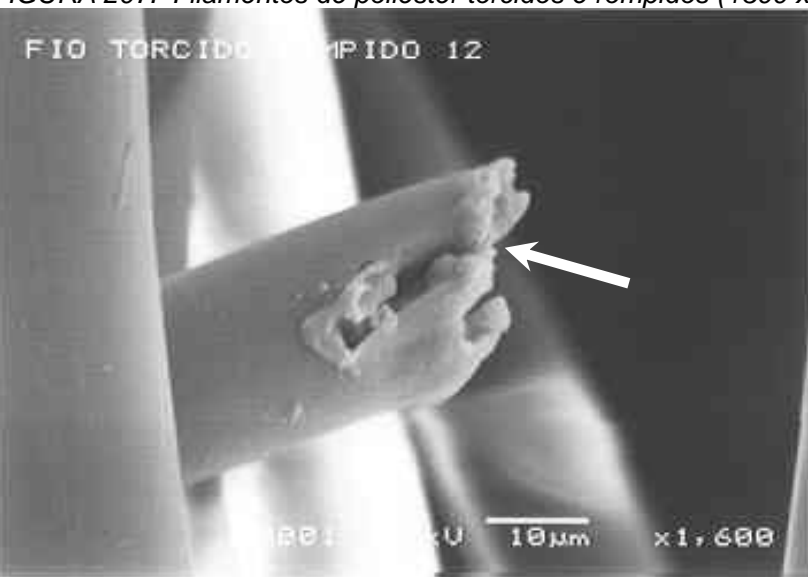

FIGURA 209. Filamentos de poliéster torcidos e rompidos (1600 x)

Os filamentos de poliéster tipo torcidos e rompidos apresentam uma face de fratura multiaxial nas Figuras 208 e 209 e sinais de intensa contaminação nas Figuras 204, 206 e 207. Na figura 205 é mostrada deformação plástica em um dos filamentos. 
Nas Figuras 210 a 215 são mostrados os perfis de fratura para os filamentos de poliéster do tipo construídos e rompidos.
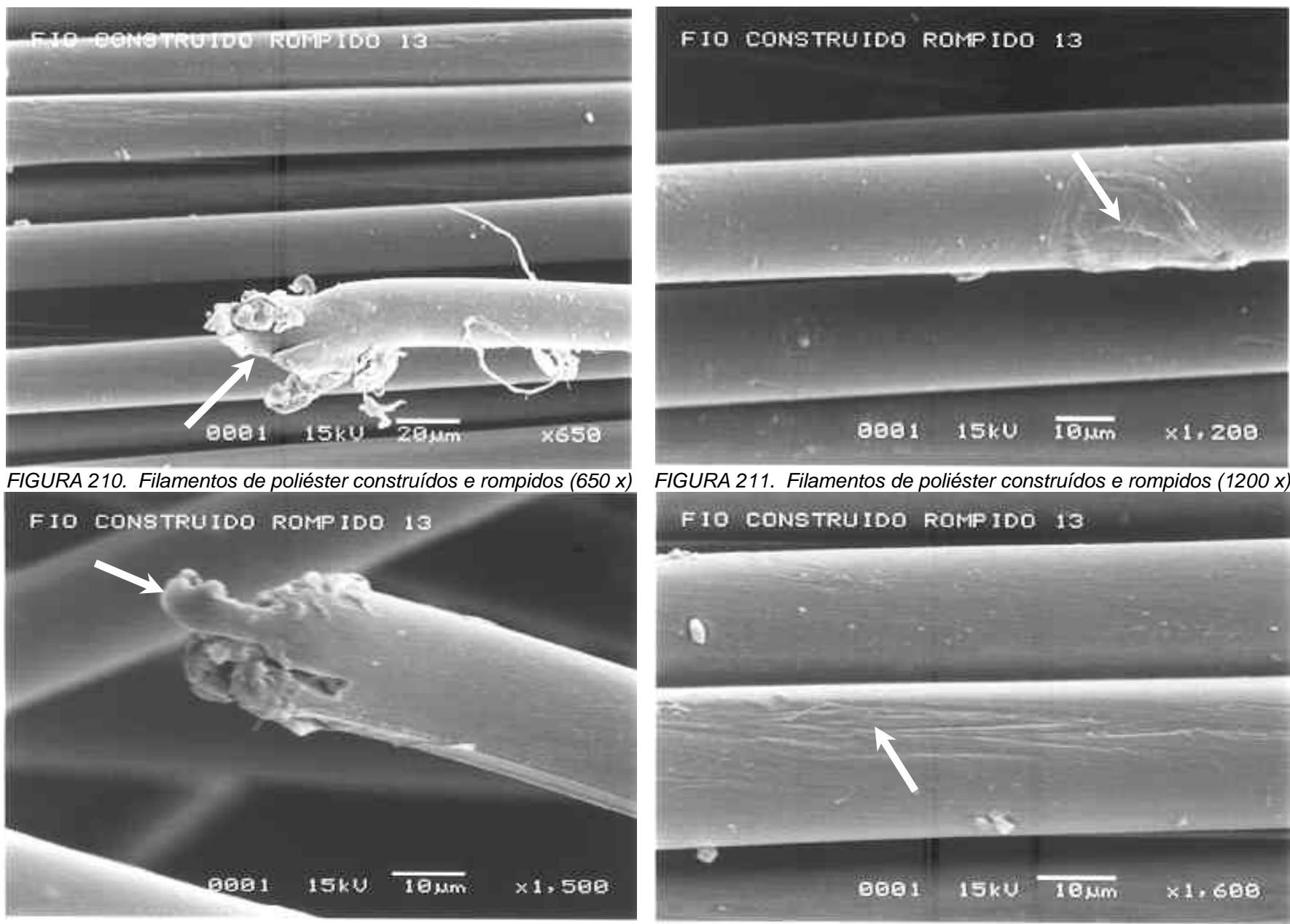

FIGURA 211. Filamentos de poliéster construídos e rompidos (1200 x)

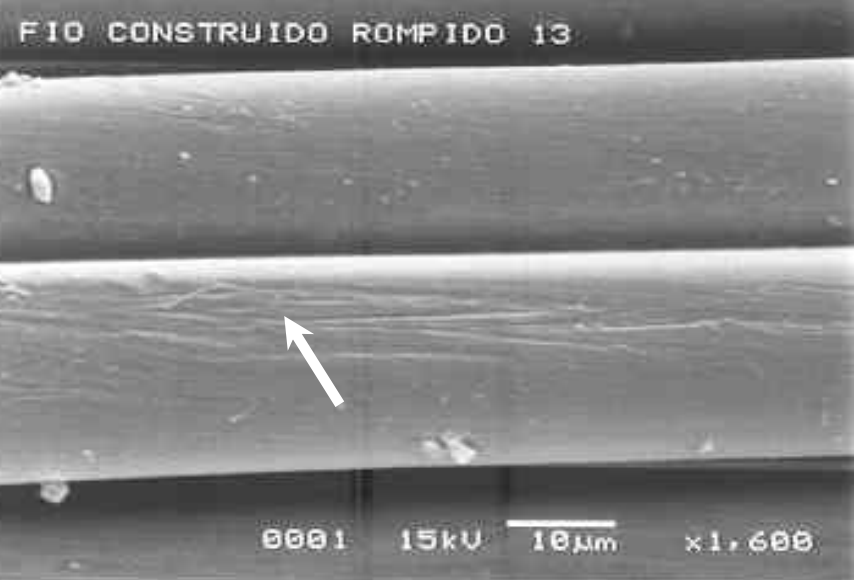

FIGURA 212. Filamentos de poliéster construídos e rompidos (1500x)

FIGURA 213. Filamentos de poliéster construídos e rompidos (1600x)
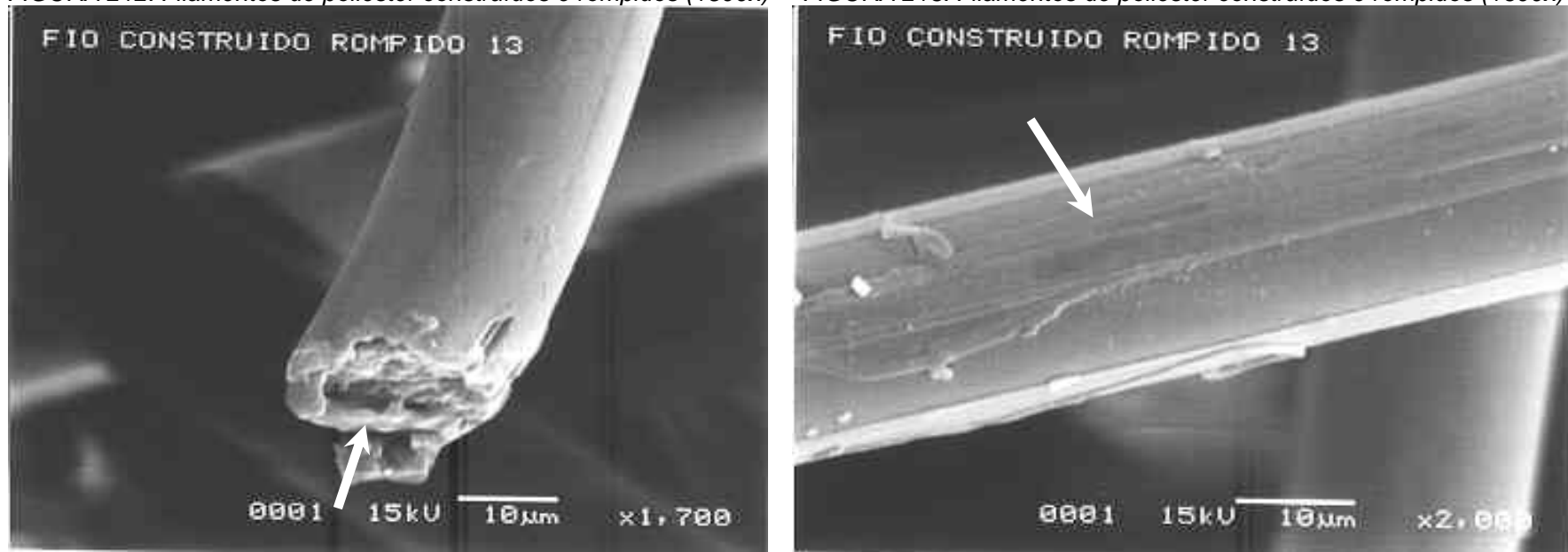

FIGURA 214. Filamentos de poliéster construídos e rompidos (1700x) FIGURA 215. Filamentos de poliéster construídos e rompidos (2000x) Os filamentos de poliéster tipo construídos e rompidos apresentam uma face de fratura multiaxial com intensa deformação nas Figuras 210, 212 e 214. Nas Figuras 213 e 215 é mostrada deformação plástica do tipo ranhuras longitudinais e na Figura 210 é mostrado a intensa deformação na face de fratura do filamento. 
Nas Figuras 216 a 221 são mostrados os perfis de fratura para os filamentos de poliéster do tipo dipados e rompidos.

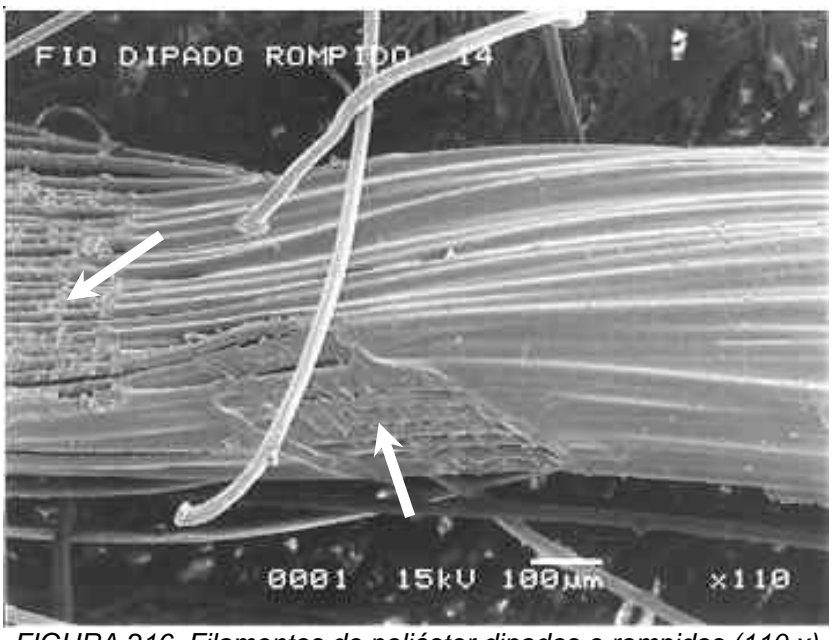

FIGURA 216. Filamentos de poliéster dipados e rompidos $(110 \mathrm{x})$

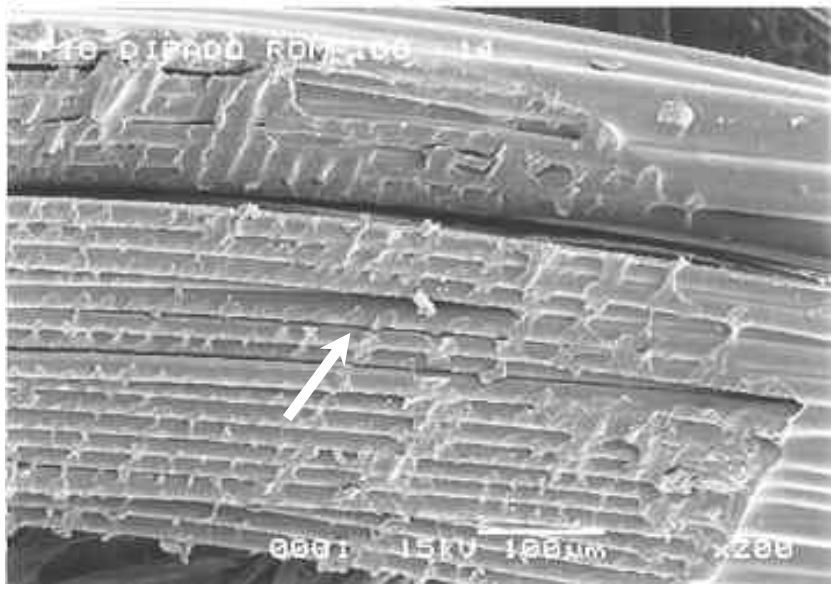

FIGURA 218. Filamentos de poliéster dipados e rompidos (200 x)

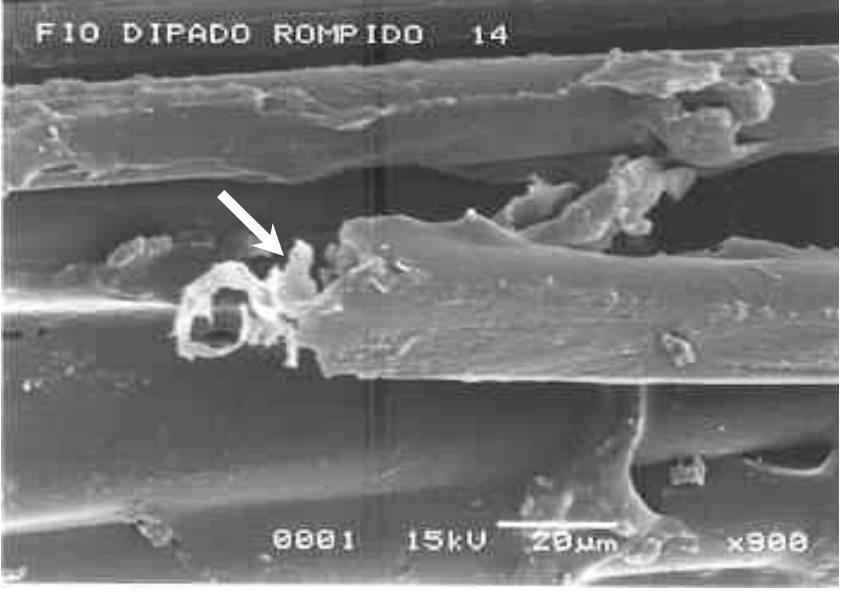

FIGURA 220. Filamentos de poliéster dipados e rompidos (900 x)

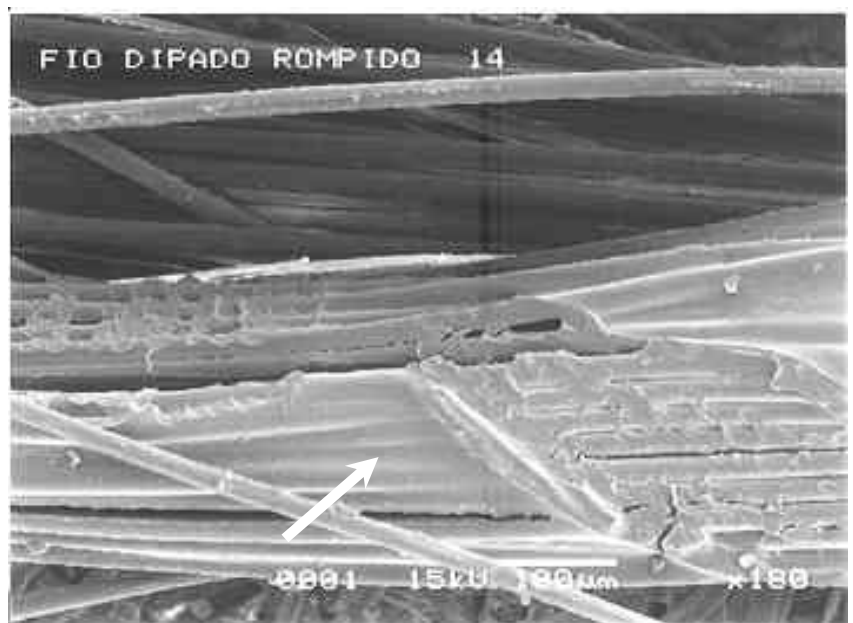

FIGURA 217. Filamentos de poliéster dipados e rompidos $(180 \mathrm{x})$

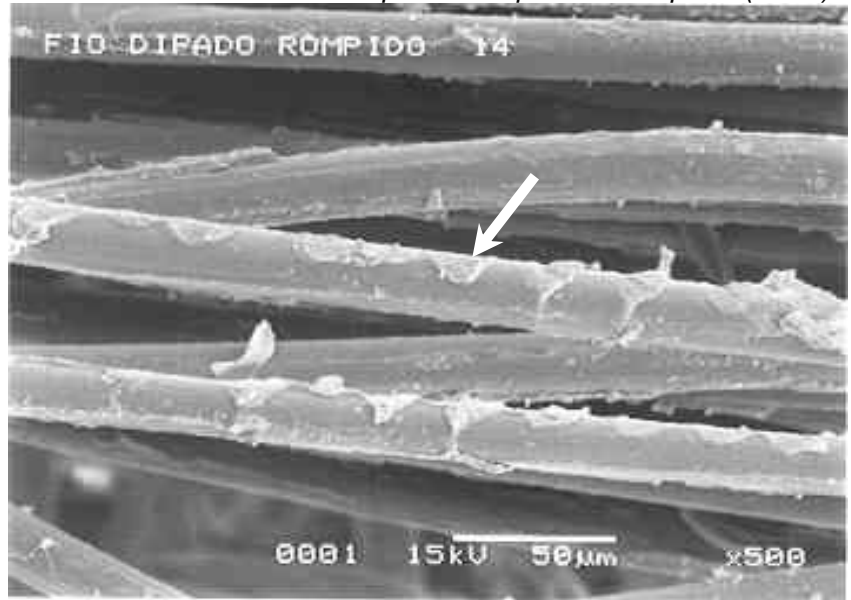

FIGURA 219. Filamentos de poliéster dipados e rompidos (500 x)

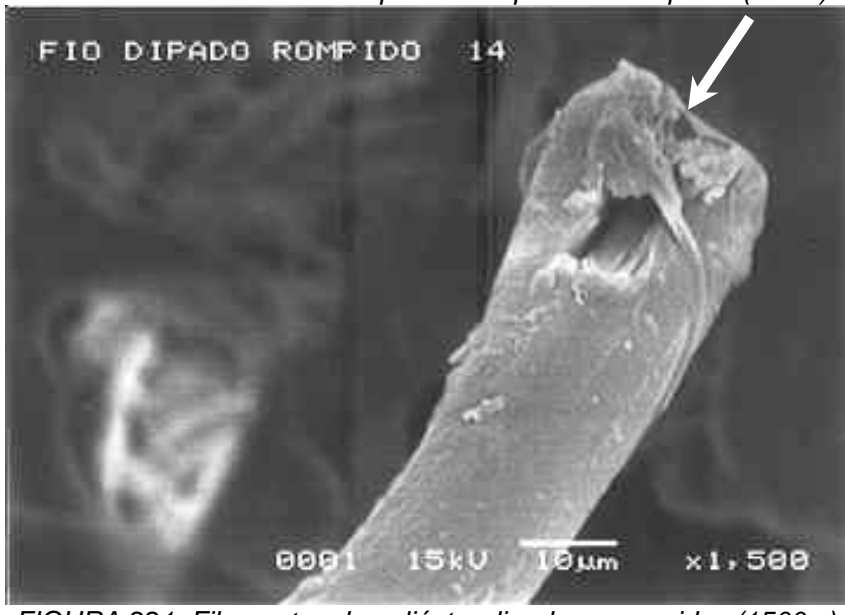

FIGURA 221. Filamentos de poliéster dipados e rompidos (1500 x) Os filamentos de poliéster tipo dipados e rompidos apresentam uma face de fratura multiaxial com intensa deformação como mostrado nas Figuras 220 e 221, sinais de contato da fibra da trama com pontos de falha na impregnação da solução de dipagem nas Figuras 216 a 219 e impregnação pela solução de dipagem, conforme é mostrada na Figura 217. 
Nas Figuras 222 a 227 são mostrados os perfis de fratura para os filamentos de poliéster do tipo vulcanizados e rompidos.

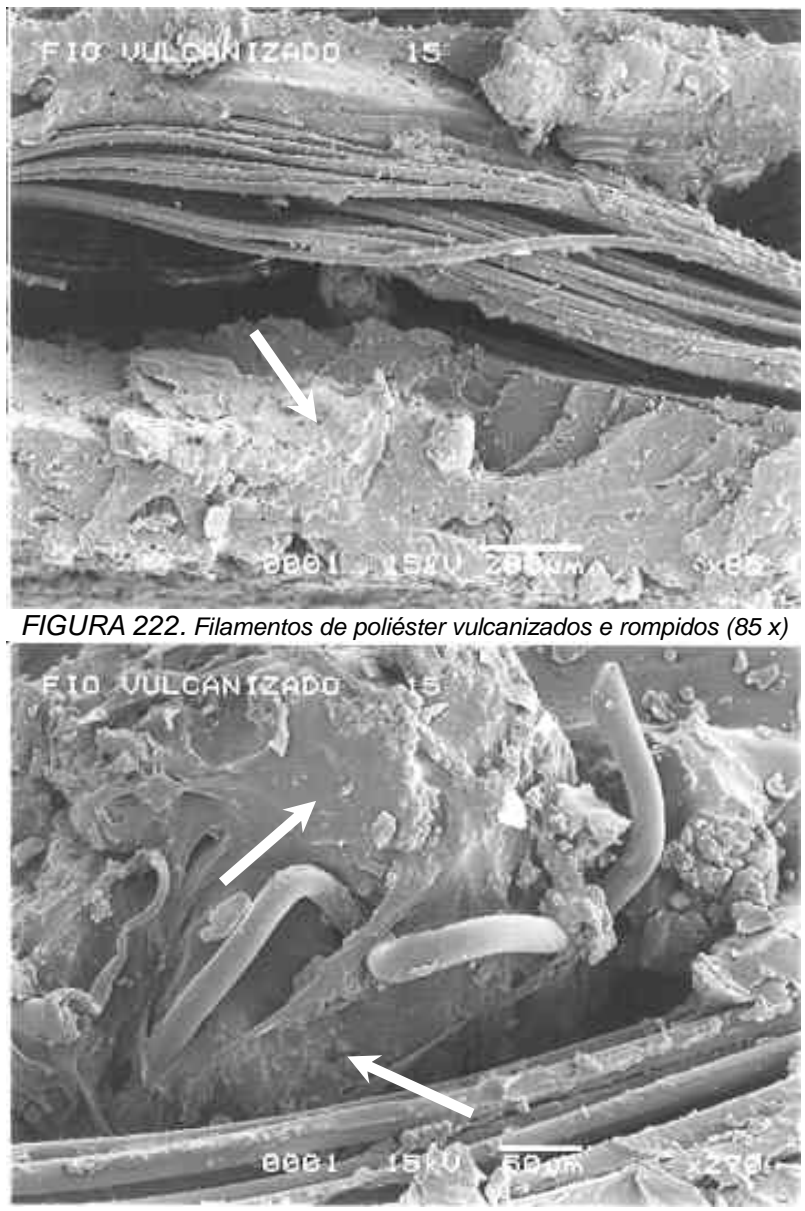

FIGURA 224. Filamentos de poliéster vulcanizados e rompidos $(270 x)$

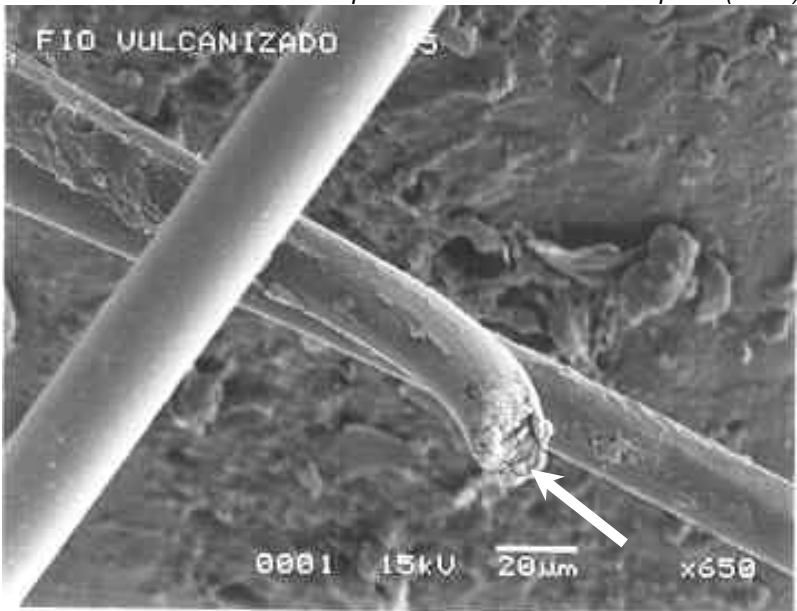

FIGURA 226. Filamentos de poliéster vulcanizados e rompidos (650 x)

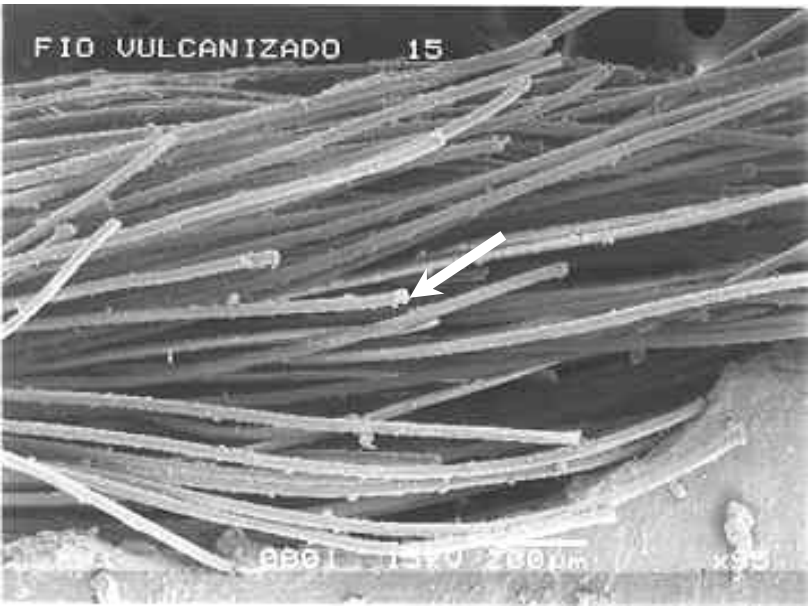

FIGURA 223. Filamentos de poliéster vulcanizados e rompidos (95 x)

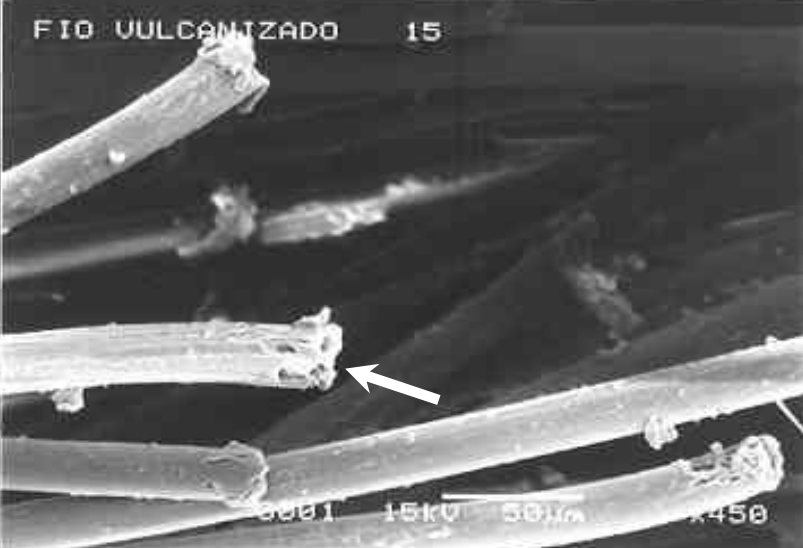

FIGURA 225. Filamentos de poliéster vulcanizados e rompidos (450 x)
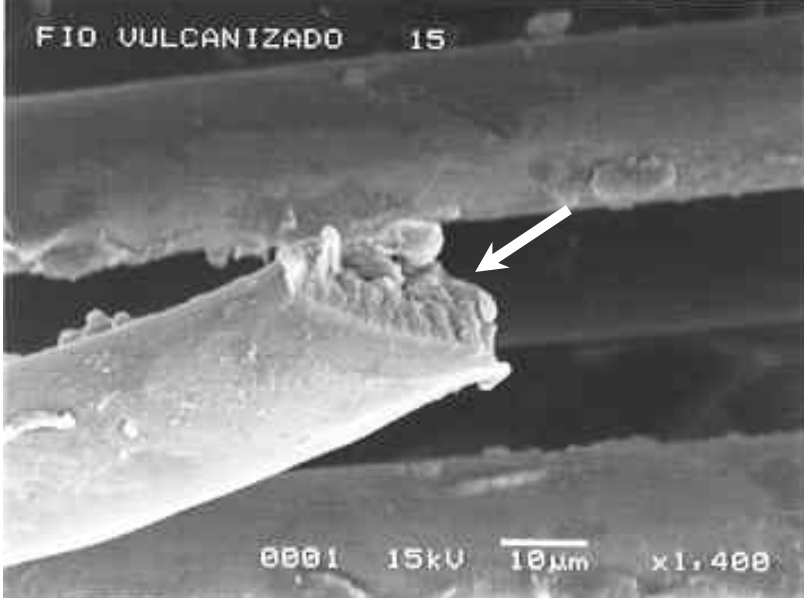

FIGURA 227. Filamentos de poliéster vulcanizados e rompidos (1400 x)

Os filamentos de poliéster tipo vulcanizados e rompidos apresentam uma face de fratura multiaxial nas Figuras 225 a 227. Na Figura 223 é mostrado um perfil de fratura heterogêneo, ou seja, com rompimentos desordenados e sem um padrão definido, inclusive filamentos com deformação plástica sem rompimento aparente. Nas Figuras 222 e 224 é mostrada intensa impregnação de borracha. 
A seguir são selecionadas algumas fotos da análise por microscopia eletrônica de varredura relacionadas ao surgimento de contaminações, marcas, deformações plásticas e descamações, provenientes ou não, das etapas de processamento das fibras de náilon e poliéster para um breve comentário sobre as possíveis causas.

Nas Figuras 228 a 231 são mostrados os filamentos de náilon e poliéster com surgimento de contaminações.

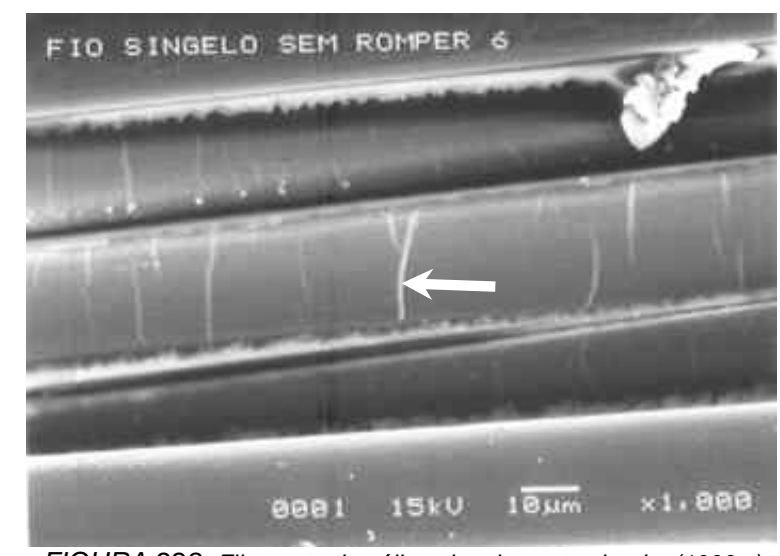

FIGURA 228. Filamento de nálon singelo contaminado (1000 x)

F TO SINGELO SEM ROMPER I6

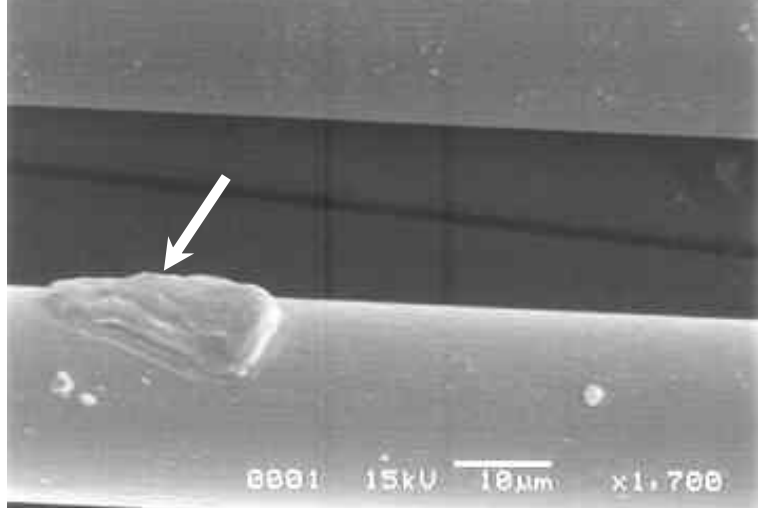

FIGURA 230. Filamento de poliéster torcido contaminado (1700 x)

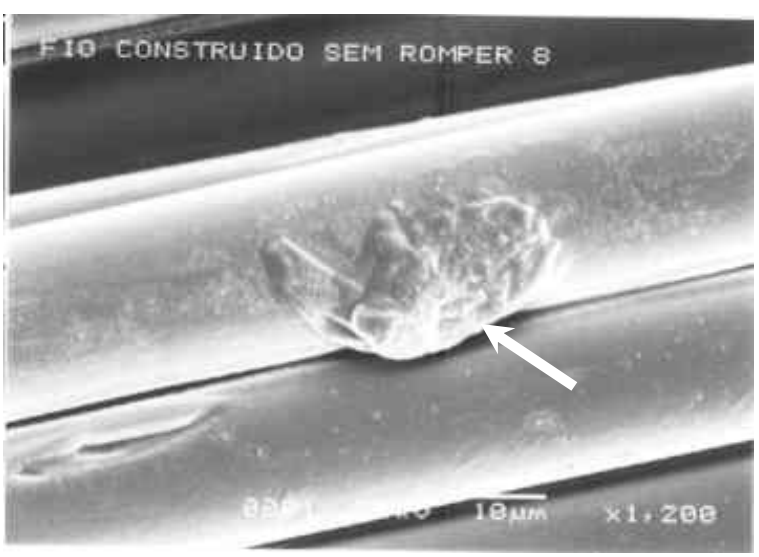

FIGURA 229. Filamento de náilon construído contaminado (1200x) FIO TOREIDO SEM ROMPER 17

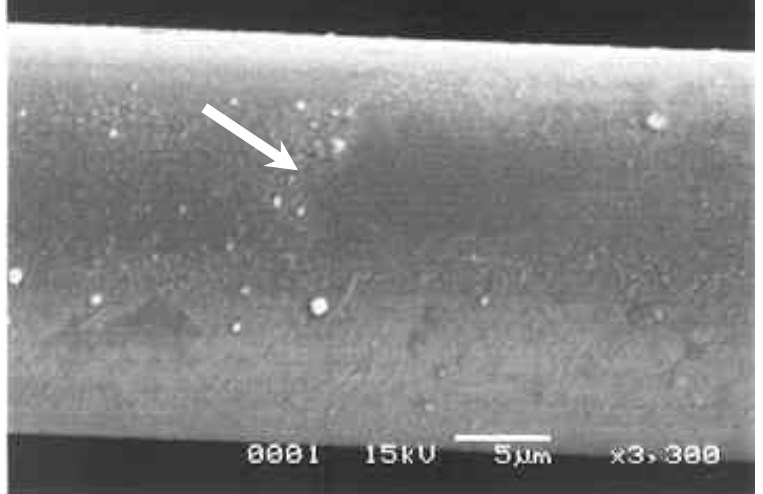

FIGURA 231. Filamento de poliéster singelo contaminado (3300 x)

Pode ser observado na Figura 228 sinais de contaminação na superfície dos filamentos, que podem ter sido causados durante a etapa de fiação da fibra pelos agentes tipo óleos, aditivos para adesão, água, entre outros; utilizados no processamento. Nas Figuras 231 são mostradas contaminações superficiais por pequenas partículas e nas Figuras 229 e 230 são mostradas contaminações maiores, ambas podem ter sido causadas durante o mesmo processo de fiação das fibras. Estas contaminações podem influenciar na redução de área de tratamento por dipagem e na perda de propriedades de adesão na interface fibra-borracha após a vulcanização. 
Nas Figuras 232 a 235 são mostrados os filamentos de náilon e poliéster com o surgimento de marcas superficiais.

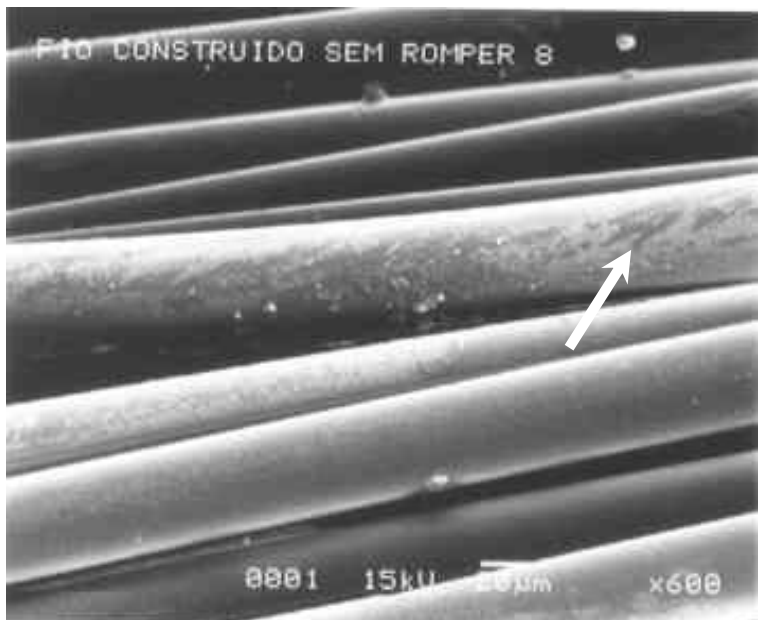

FIGURA 232. Filamento de náilon construído com manchas (600 x)

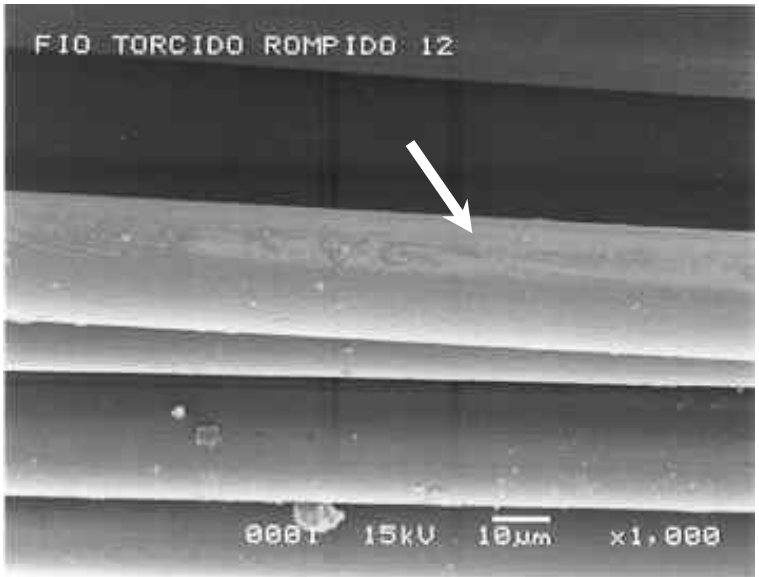

FIGURA 234. Filamento de poliéster construído com manchas (1000 x)

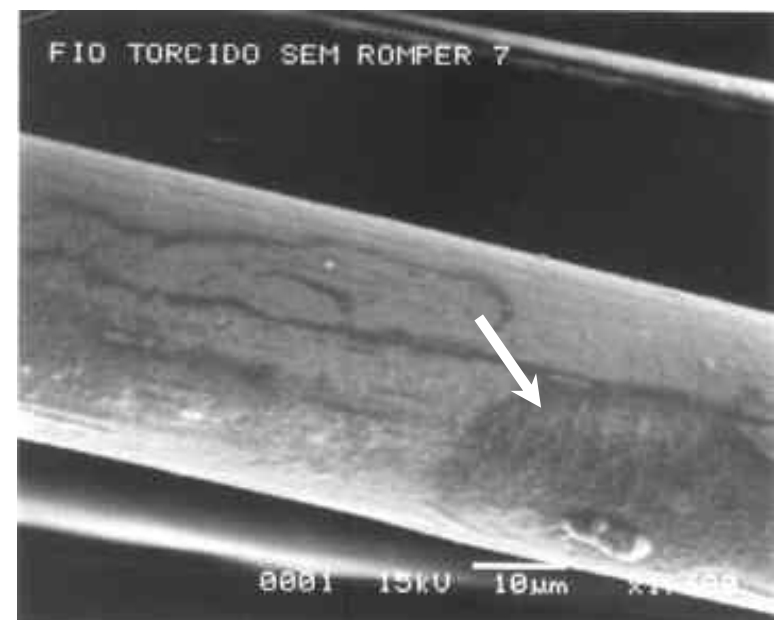

FIGURA 233. Filamento de náilon torcido com manchas (1600 x)

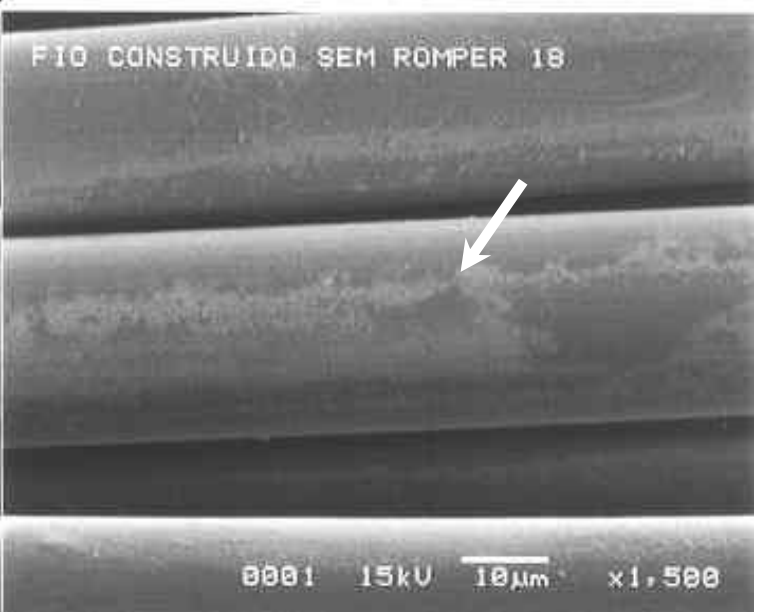

FIGURA 235. Filamento de poliéster torcido com manchas (1500 x)

Podem ser observados nas Figuras dos filamentos de náilon e poliéster sinais de marcas superficiais, que podem ter sido causadas por desgaste devido ao atrito do contato entre os filamentos, e podem ter surgido durante as etapas de fiação ou do processamento da fibra. Estas marcas superficiais podem dar início a microtrincas e causar a fratura prematura dos filamentos, reduzir a qualidade no tratamento superficial feito com aditivos na etapa de fiação e redução nas propriedades de adesão na interface fibra-borracha após a etapa de vulcanização. 
Nas Figuras 236 a 239 são mostrados os filamentos de náilon e poliéster com deformação plástica.

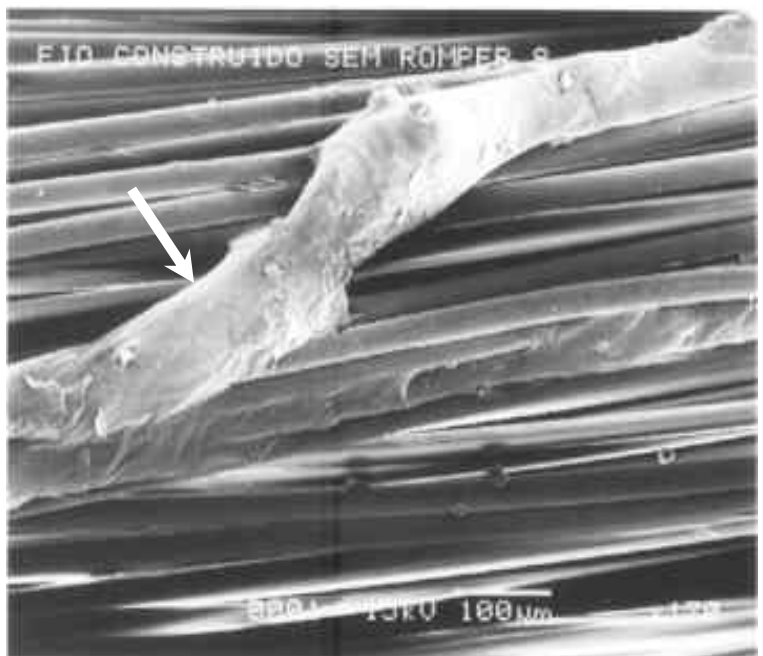

FIGURA 236. Filamento de náilon construído deformado (170 x)
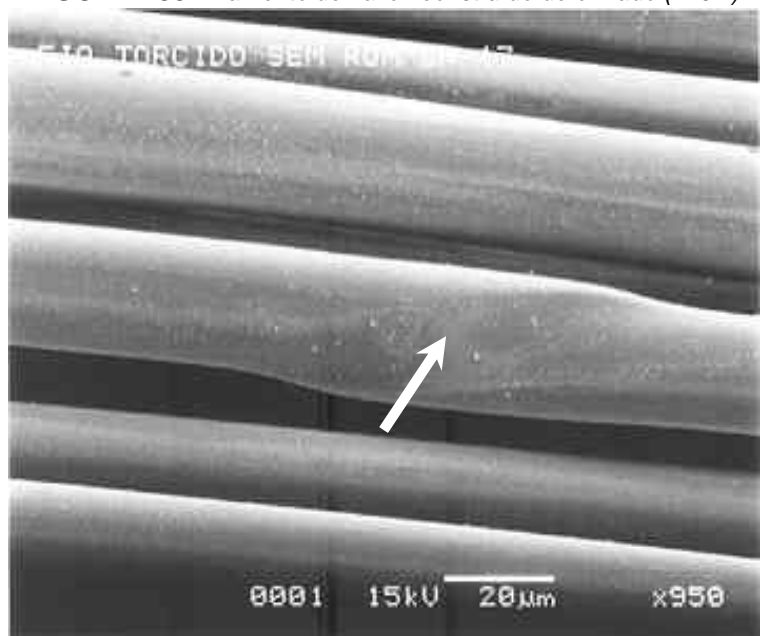

FIGURA 238. Filamento de poliéster torcido deformado (950 x)

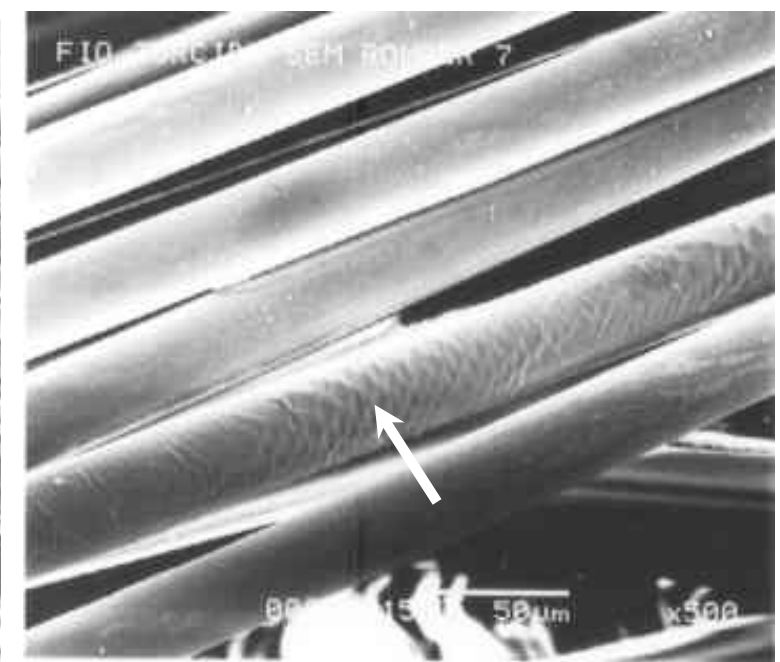

FIGURA 237. Filamento de náilon torcido deformado (500 x)
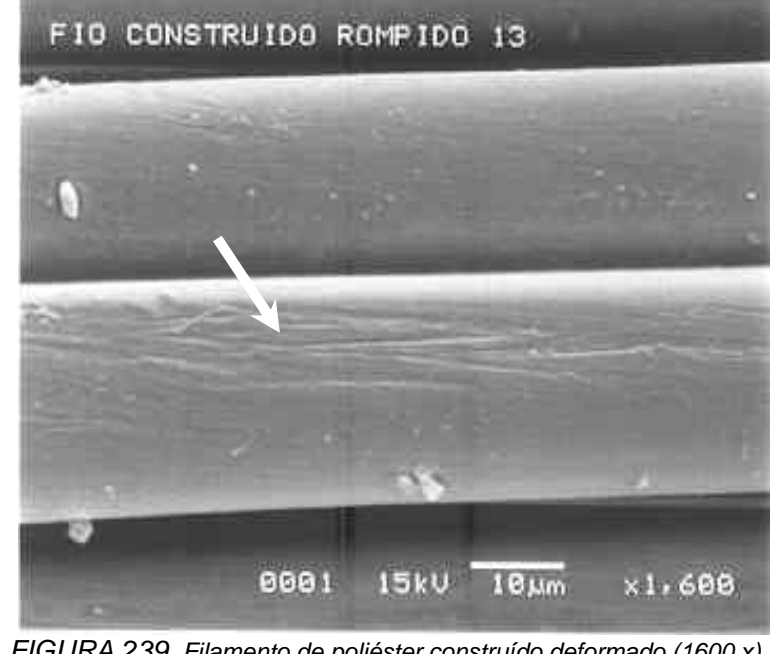

Podem ser observados nas Figuras dos filamentos de náilon e poliéster sinais de deformação plástica, que podem ter sido causadas durante as etapas de fiação pelo seu perfil do tipo estrias e ranhuras (Figuras 237 e 239) ou no processamento da fibra pelo seu perfil do tipo flexão e torção (Figuras 236 e 238). Estas deformações podem causar a fratura prematura dos filamentos, reduzindo as propriedades mecânicas das fibras, tecidos e do produto de engenharia que será produzido. 
Nas Figuras 240 e 241 são mostrados os filamentos de náilon com sinais de descamação.

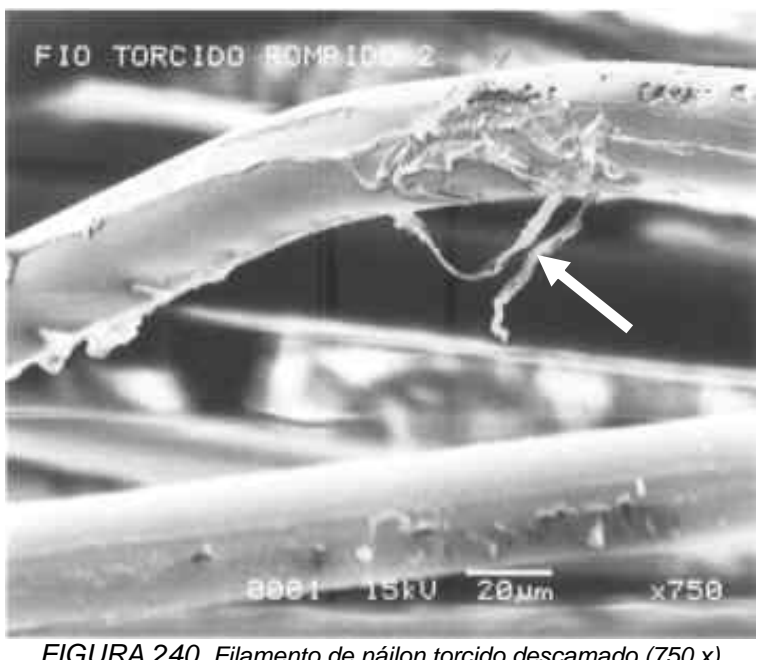

FIGURA 240. Filamento de náilon torcido descamado (750 x)

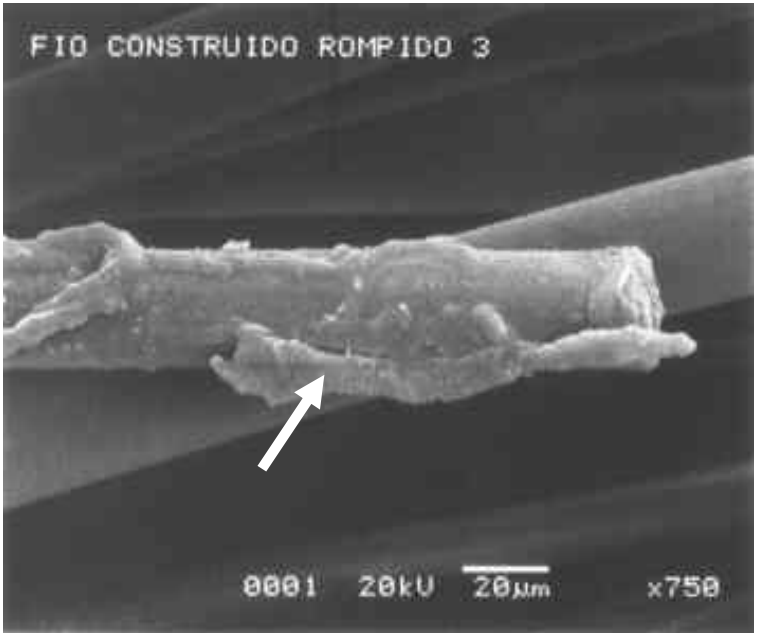

FIGURA 241. Filamento de náilon construído descamado (750 x)

Conforme citado no item 2.2.3.5, segundo Kerr et al. (2005), o carregamento cíclico nas fibras poliméricas pode resultar na ruptura do material por fadiga mecânica. O processamento induz a tensões residuais de compressão na superfície da fibra, conduzindo ao início da trinca na qual normalmente a morfologia da fratura é caracterizada como delaminação axial. Considerando que os processos de delaminação e descamação são similares e adotando que o carregamento cíclico pode ser do tipo multiaxial, esta citação é usada para explicar a ocorrência de descamações em filamentos poliméricos por carregamento multiaxial.

Mediante os comentários anteriores relacionados às deformações plásticas, estas descamações também causam a fratura prematura dos filamentos, reduzindo as propriedades mecânicas das fibras, tecidos e do produto de engenharia que será produzido. 
Antes de iniciar a discussão relacionada às análises por microscopia eletrônica de varredura, vamos fazer um breve comentário sobre os tipos de fratura encontrados na literatura.

Normalmente a fratura frágil ocorre nos materiais com maior rigidez, tais como fibras de vidro, cerâmica, carbono e elastoméricas. Nas Figuras 242 e 243 são mostradas as formas de fratura em filamentos de fibra de vidro (material cerâmico).

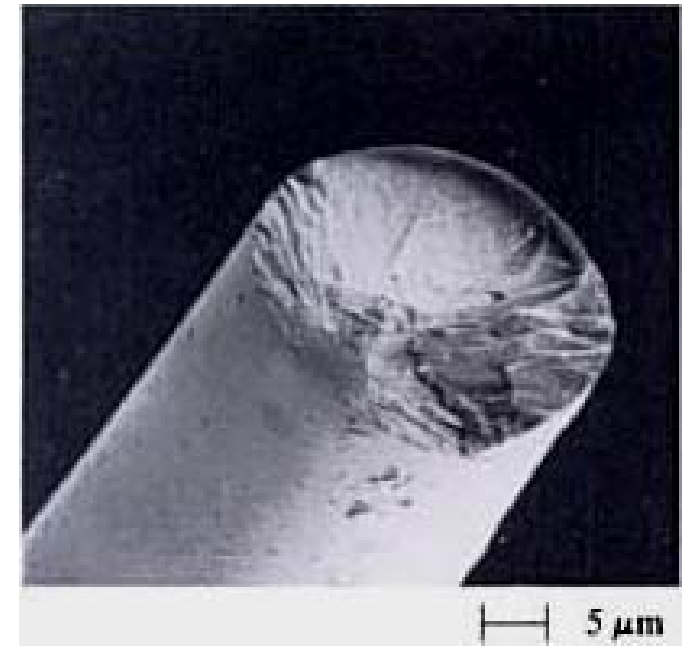

FIGURA 242. Plano de clivagem

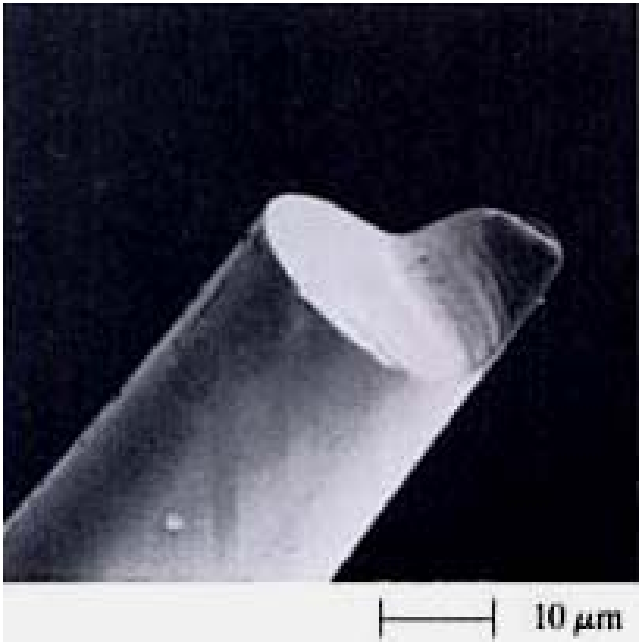

FIGURA 243. Deslocamento lateral

Para a fratura dúctil, existe uma extensão elástica inicial até ocorrer o escoamento plástico, seguindo com a queda da tensão após uma pequena elevação e alongamento a uma tensão constante até o início de formação do pescoço.

Muito antes de se iniciarem as quebras da fibra, um especialista pode detectar quando ocorrerá a fratura e subsequentemente uma grande trinca será facilmente visível (Hearle et al., 1998). Nas Figuras 244 a 246 são mostrados os mecanismos de fratura dúctil de um filamento de náilon 6.6. 


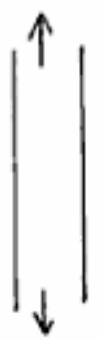

(a)

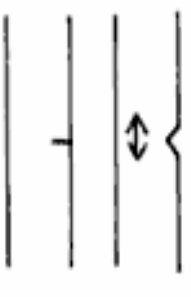

(b1) (b2)

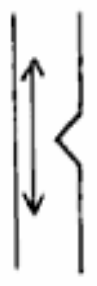

(c)

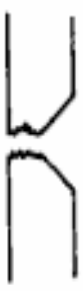

(d)

(a) Carregamento (b) Início da trinca (b2) Abertura

(c) Crescimento e propagaçăo (d) Fratura

FIGURA 244. Sistema de propagação da trinca
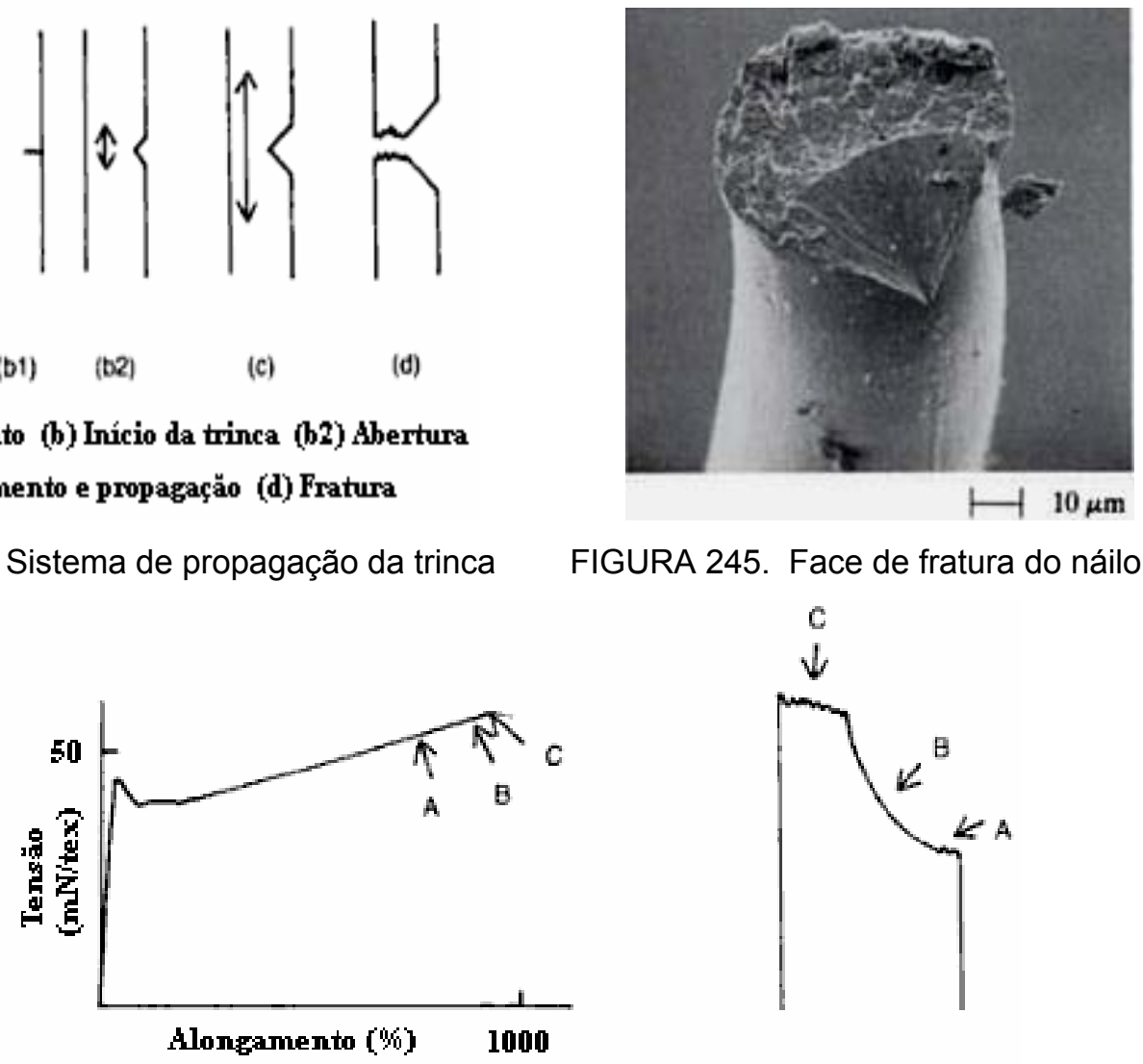

FIGURA 245. Face de fratura do náilon 6.6

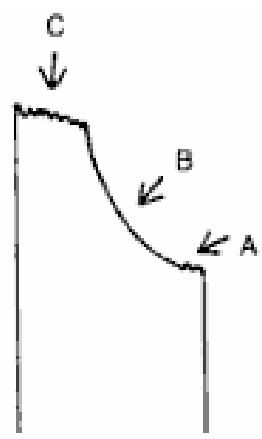

A: Início B: Propagação e C: Fratura

FIGURA 246. Estágios da trinca

Quando a fratura ocorre a velocidades baixas o calor pode ser perdido para o ambiente, mas a velocidades altas o calor gerado aquece o filamento na região da fratura.

O amolecimento, próximo à fusão, presumidamente permite então que a ruptura ocorra pelo fluxo localizado no material viscoso, de modo que qualquer geometria da trinca inicial é perdida e a contração (snap-back) após o rompimento causa o colapso do material sob a forma de um cogumelo. A forma exata final dependerá das forças termomecânicas (Hearle et al., 1998).

Nas Figuras 247 e 248 são mostradas as formas de fratura a velocidade alta do tipo cogumelo em filamentos das fibras de náilon 6.6 e poliéster, nas quais são observadas estrias transversais para o poliéster. 


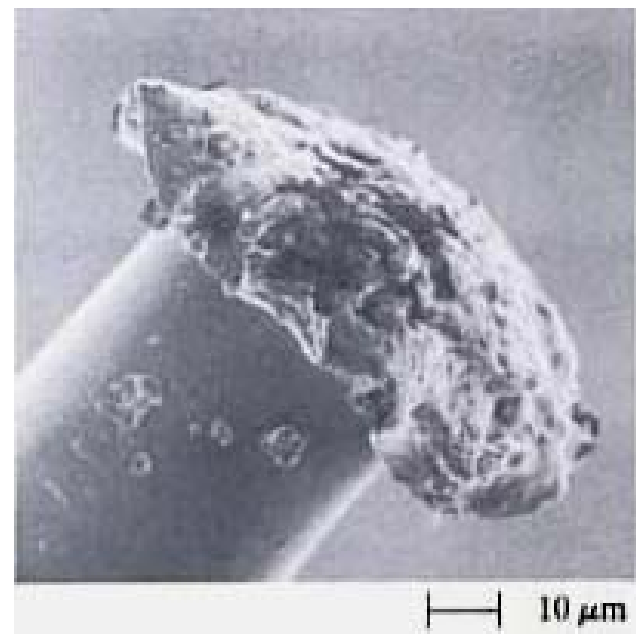

FIGURA 247. Fratura do náilon 6.6

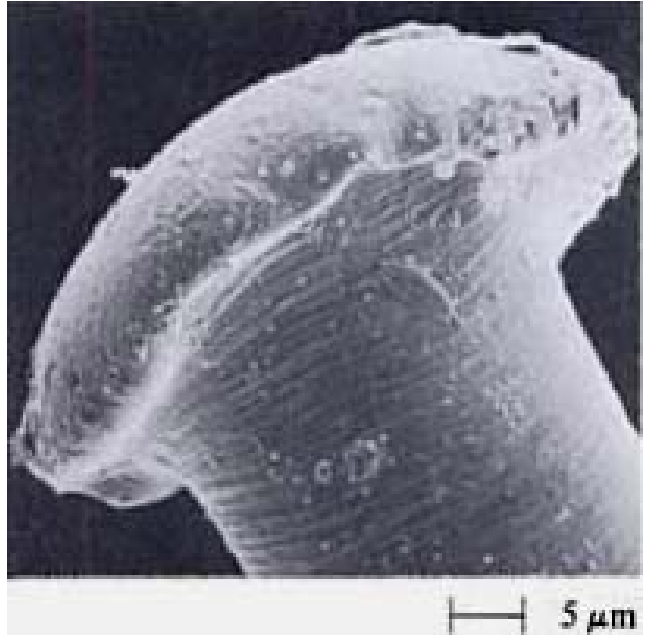

FIGURA 248. Fratura do poliéster

Ramirez et al. (2004) demonstraram por análise de espectroscopia Raman, em amostras de náilon 6.6 submetidas a ensaios mecânicos com carregamento cíclico, que as fibras se comportam de maneira diferente na fadiga. Nas figuras 249 e 250 são mostradas as formas de fratura por fadiga cíclica do filamento de náilon 6.6.

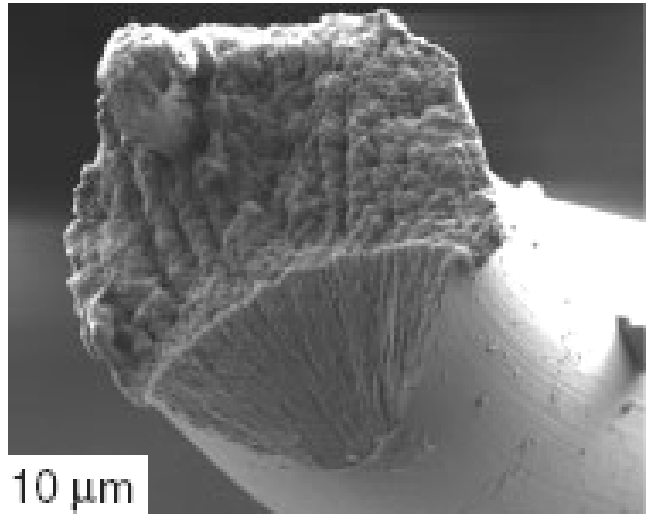

FIGURA 249. Fratura por fadiga

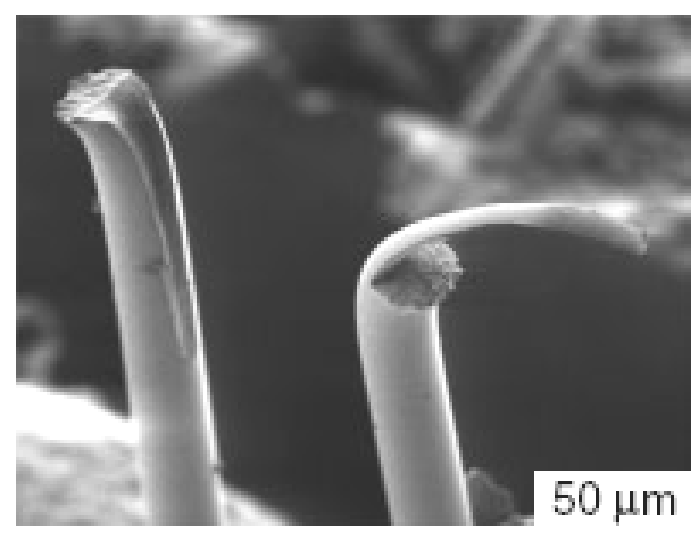

FIGURA 250. Morfologia da fibra

Após estas breves considerações pode-se discutir sobre as análises de microscopia eletrônica de varredura realizados nas fibras do tipo náilon e poliéster. 
Somente as micrografias relacionadas aos perfis de fratura para os filamentos das fibras tipo singelo, ou seja, anterior ao início das etapas dinâmicas de processamento, apresentaram o perfil de fratura dúctil mencionado na literatura, porém com pequena deformação na sua face. Nenhuma das secções das fraturas dos filamentos de náilon e do poliéster analisados, após as etapas de torção, construção, dipagem e vulcanização, representaram os perfis mencionados na literatura, e as faces apresentaram formas heterogêneas mostrando existir influência das tensões impostas pelas etapas de processamento das fibras.

Estes resultados mostram reais evidências da existência do estado de múltiplas tensões (tração, torção, flexão, compressão e impacto); inclusive tensões multiaxiais, ou seja, conjugadas entre si, durante as etapas de processamento dinâmico das fibras de náilon e poliéster, o qual pode causar a redução das propriedades mecânicas do produto final (Cardoso; Andrade, 2009b).

Para o estudo da adesão interfacial nos tecidos de náilon e poliéster, foi realizado um breve comparativo do nível de impregnação na sua interface fibraborracha. Para isto, foram selecionadas algumas figuras de náilon e poliéster da seção de $M E V$, após a etapa de vulcanização, com ampliação a mais adequada possível. O nível de impregnação superficial da borracha tem influência direta nas propriedades de adesão relacionadas aos tecidos com fibras do tipo náilon e poliéster utilizados em correias transportadoras. Ensaios de adesão entre as coberturas de borracha e os tecidos de fibras foram realizados para comprovação dos pontos levantados, e são relatados a seguir.

Nas Figuras 251 a 256 são mostrados os perfis da superfície, quanto a impregnação na interface fibra-borracha, para os filamentos dos tipos náilon e poliéster do tipo vulcanizados. 


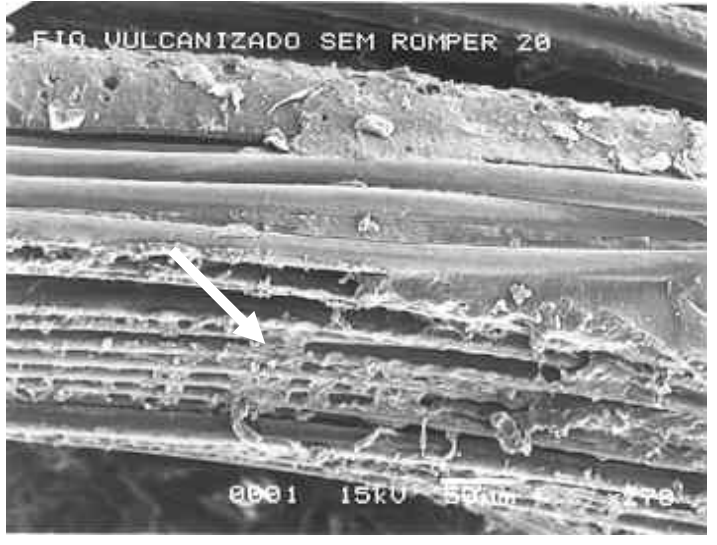

FIGURA 251 - Superfície do poliéster vulcanizado $(250$ x)

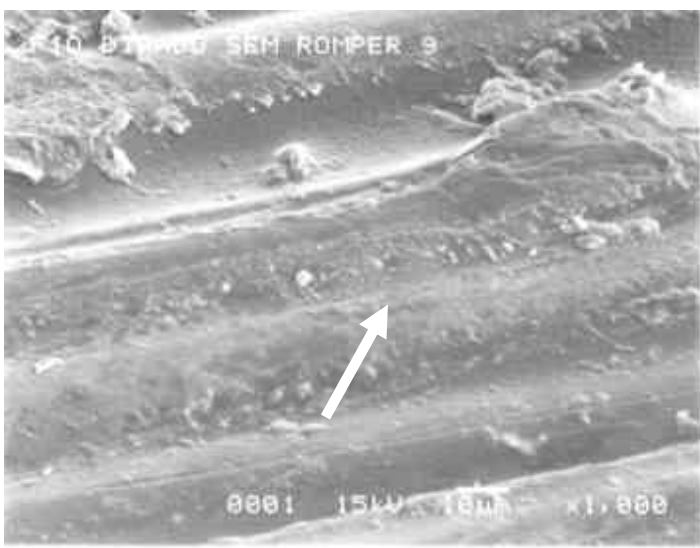

FIGURA 253- Superfície do náilon dipado (1000 x)

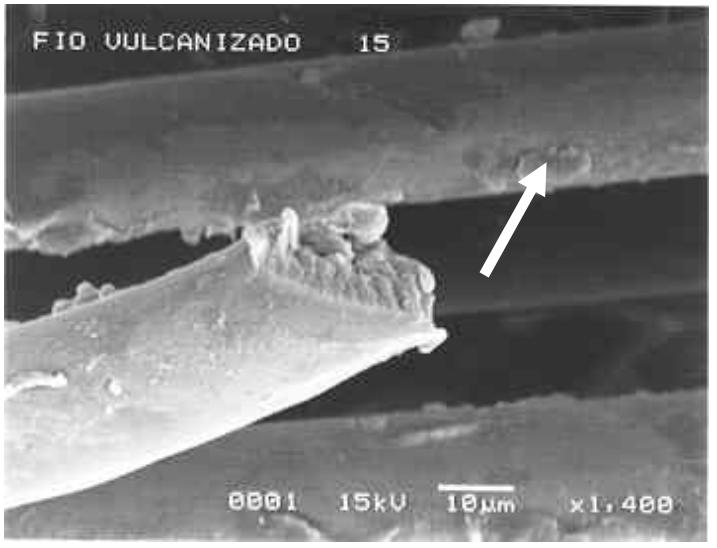

FIGURA 255- Filamento de poliéster vulcanizado (1400 x)

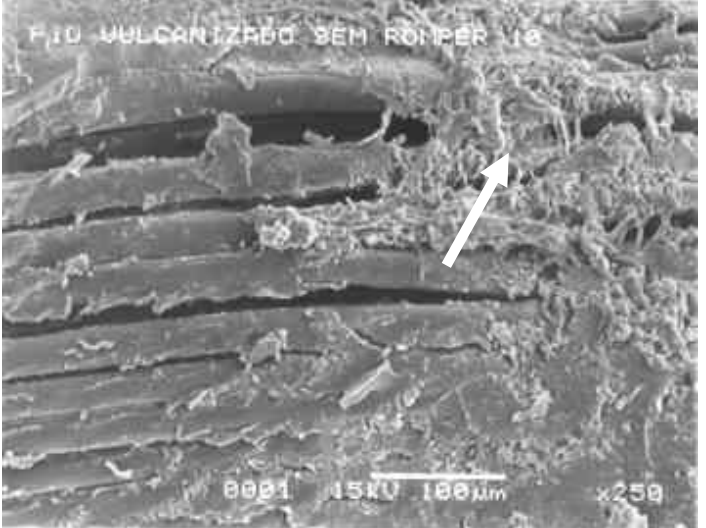

FIGURA 252 - Superfície do náilon vulcanizado $(270$ x)

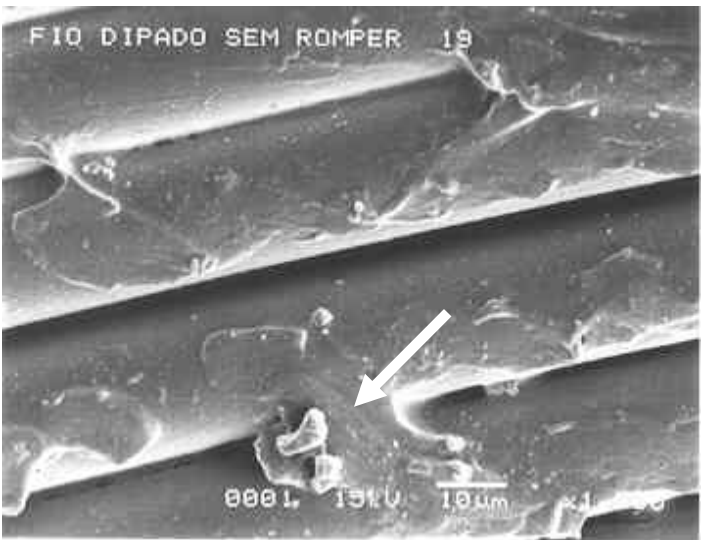

FIGURA 254- Superfície do poliéster dipado (1000 x)

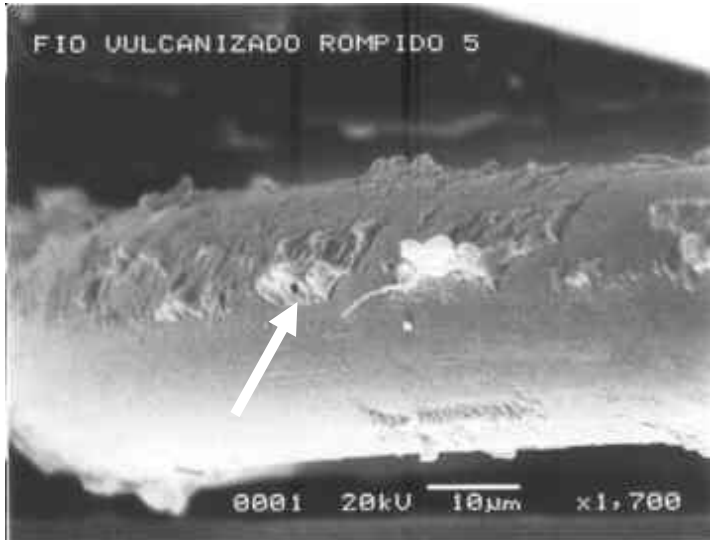

FIGURA 256 - Filamento de náilon vulcanizado (1700 x)

Comparando-se as Figuras 251 a 256, observa-se que as fibras de náilon apresentam maior quantidade de borracha presente na interface e, consequentemente, melhores propriedades de adesão. Este fato é confirmado mediante o histórico de resultados de adesão entre os componentes da correia transportadora, ou seja, o tecido e as coberturas de borracha. 
Conforme comentários sobre a infiltração de borracha na interface e para confirmação dos fatos, foram realizados ensaios de adesão, mediante norma ISO 252, $3^{a}$ edição de 2007, em doze amostras, sendo seis amostras com tecido de náilon e seis amostras com tecido de poliéster. Para todas as amostras foram consideradas a mesma base de material, ou seja, borracha natural, e os tecidos de náilon e poliéster foram dipados com o mesmo tipo de solução, mesma composição química e nas mesmas condições de tempo de exposição, velocidade e temperaturas nas zonas de aquecimento e secagem. Na Tabela 15 são apresentados os resultados de adesão entre as coberturas de borracha e os tecidos de náilon e de poliéster das amostras das correias transportadoras selecionadas para este estudo.

TABELA 15. Resultados de adesão para os tecidos de náilon e de poliéster

\begin{tabular}{|c|c|c|c|c|c|c|c|c|c|c|c|c|c|c|}
\hline \multicolumn{15}{|c|}{ ENSAIO DE ADESÃO (N/mm) } \\
\hline Componente & \multicolumn{6}{|c|}{ Náilon } & \multicolumn{2}{|c|}{ Média } & \multicolumn{4}{|c|}{ Poliéster } & \multicolumn{2}{|r|}{ Média } \\
\hline Cobertura Borracha e $1^{\circ}$ Tecido & 9,6 & 11,9 & 10,2 & 9,5 & 9,5 & 11,0 & 10,3 & 8,2 & 7,5 & 6,8 & 6,6 & 7,0 & 6,3 & 7,1 \\
\hline Cobertura Borracha e $2^{\circ}$ Tecido & 6,5 & 6,6 & 6,3 & 8,1 & 6,1 & 6,3 & 6,6 & 4,9 & 4,7 & 4,6 & 4,9 & 4,4 & 3,7 & 4,5 \\
\hline Entre o $1^{\circ} \mathrm{e}$ o $2^{\circ}$ Tecido & 14,5 & 13,5 & 16,6 & 14,9 & 15,1 & 17,0 & 15,3 & 8,9 & 8,9 & 8,4 & 7,7 & 7,9 & 8,4 & 8,4 \\
\hline
\end{tabular}

Comparando-se os resultados obtidos nos ensaios de adesão podem ser feitos os seguintes comentários:

- O índice de adesão entre a cobertura de borracha e $01^{\circ}$ tecido foi em torno de $55,8 \%$ maior para o náilon;

- $O$ índice de adesão entre a cobertura de borracha e o $2^{\circ}$ tecido foi em torno de $46,8 \%$ maior para o náilon;

- O índice de adesão entre o $1^{\circ}$ e o $2^{\circ}$ tecido foi em torno de $83 \%$ maior para o náilon;

- Diante das evidências relatadas é possível afirmar que, para correias transportadoras, o tecido de náilon possui propriedades de adesão superiores ao tecido de poliéster. 


\section{CONCLUSÕES}

Com base nos objetivos propostos inicialmente, os quais sugerem 0 contexto deste estudo e tendo como principal foco o estudo das fibras do tipo náilon e poliéster, sujeitas ao carregamento multiaxial com exposição à temperatura e tensões conjugadas entre si; a seguir são mostradas as conclusões deste projeto de pesquisa.

O desvio encontrado da força teórica versus a força experimental para a fibra de náilon, foi em média 2,19\% e para a fibra de poliéster em média 6,1 , sendo para os resultados de tenacidade em torno de $+/-2 \%$.

As fibras de náilon e poliéster apresentaram redução nas suas propriedades de resistência à ruptura após o processamento.

Os ensaios de tração monitorada para as fibras do poliéster tipo singelas, mostraram um mecanismo de fratura heterogêneo, onde aproximadamente 95\% dos filamentos romperam totalmente.

Os ensaios de tração monitorada para os tecidos de náilon e poliéster tipo dipados mostraram o mesmo mecanismo de fratura heterogênea encontrado nos filamentos, porém, com menor variação.

As curvas de tensão $\mathrm{x}$ deformação para os ensaios de tração dos tecidos dipados de náilon e poliéster com a velocidade de $5 \mathrm{~mm} /$ minuto mostraram uma extensão, após o pico máximo de tensão.

Os filamentos e as fibras de náilon mostraram menor incidência na variação das tensões nas etapas de processamento discutidas. 
As propriedades de ruptura, após a etapa do processo de torção das fibras, aumentaram para o náilon, em torno de $2 \%$, e para o poliéster em cerca de $0,18 \%$.

As fibras de poliéster mostraram maior queda na resistência mecânica após a etapa de dipagem, em torno de $18,9 \%$ contra $11,2 \%$ para o náilon.

Os filamentos de náilon e poliéster do tipo singelo mostraram as suas faces de fratura do tipo dúctil, com pequenas alterações nas suas secções.

A faces de fratura analisadas por MEV, após as etapas de processamento, mostraram um mecanismo heterogêneo, o qual foge ao padrão de fratura para os filamentos, encontrado na literatura.

A análise de superfície realizada por MEV mostrou a existência de contaminações nos filamentos de náilon e poliéster nas fibras singelas, torcidas e construídas.

A análise de superfície realizada por MEV mostrou a existência de marcas superficiais nos filamentos de náilon e poliéster nas fibras torcidas e construídas.

A análise de superfície realizada por MEV mostrou a existência de deformações plásticas e descamações.

A análise de superfície realizada por MEV mostrou maior impregnação na interface fibra-borracha para a fibra de náilon.

Os ensaios de adesão interfacial mostraram melhores resultados para o tecido de náilon 


\section{SUGESTÕES PARA TRABALHOS FUTUROS}

Estudar e quantificar as tensões individuais nos filamentos durante o carregamento da fibra, bem como as tensões individuais nas fibras durante o carregamento do tecido por métodos probabilísticos.

Aprimorar os ensaios de análise do mecanismo de fratura da fibra com o auxílio do dispositivo de tração das fibras com monitoramento.

Detalhar e caracterizar melhor a fratura por filamento em cada etapa de processamento, simulando as tensões multiaxiais em laboratório.

Os gráficos dos ensaios de ruptura para o tecido dipado, quando realizados em uma velocidade menor de ensaio, apresentaram uma extensão de área, ou seja, uma faixa adicional de resistência, portanto, este ponto pode ser melhor explorado para o entendimento deste fenômeno.

Analisar detalhadamente por MEV as alterações nas faces de fratura para os filamentos de náilon e poliéster singelos.

Analisar detalhadamente por MEV as superfícies dos filamentos, após a etapa final de vulcanização para caracterizar o mecanismo de adesão na interface fibraborracha em função da temperatura.

Caracterizar por Espectroscopia de Energia Dispersiva (EDS) as contaminações encontradas nos filamentos de náilon e poliéster.

Finalizar o estudo matemático por estatística de Weibull da probabilidade de falha para as fibras em cada uma das etapas de processamento descritas, utilizando um número maior de resultados adicionais. 


\section{APÊNDICE A - Estatística de Weibull}

Conforme citado no item 4.2, iniciou-se um estudo por estatística de Weibull, no qual foram selecionados os resultados das forças experimentais do item 4.1.1 (Tabelas 11 a 14), para as fibras de náilon (amostras "A" e "B") e poliéster (amostras "C" e "D") do tipo singelas. Para este estudo foi utilizada a equação 12 da função estatística de Weibull para a probabilidade de falha e a equação 132 para o parâmetro do módulo $\mathbf{m}$ de Weibull, conforme segue (Askeland; Phulé, 2003):

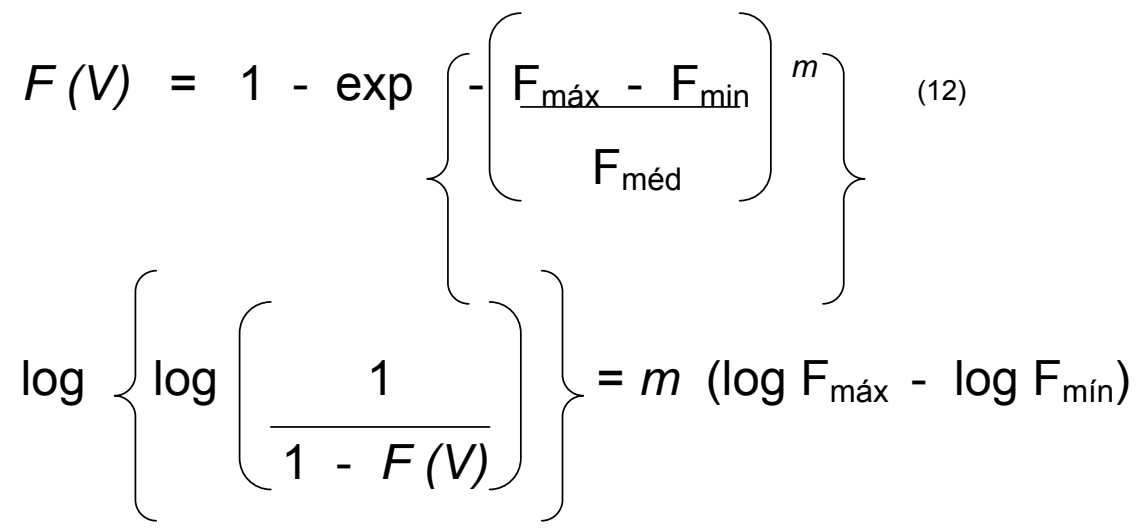

Sendo:

$F(V)=P f=$ Probabilidade de falha

$\boldsymbol{m}=>$ Parâmetro $\mathrm{m}$ de Weilbull

$F_{\text {máx }}=>F_{\text {exp }}=>$ Força experimental máxima (amostra 10)

$F_{\text {mín }}=>F_{\text {exp }}=>$ Força experimental mínima (amostra 1)

Fméd $=>$ Força média

A partir dos gráficos de Weibull a seguir e diante dos resultados, faz-se necessária a continuidade deste estudo com um número maior de amostras (mínimo 30) para a comprovação da probabilidade mostrada pela estatística de Weilbull. 
A1 - Estatística de Weibull para a fibra de náilon do tipo singela da amostra " $A$ "

\begin{tabular}{|c|c|c|c|c|c|c|c|}
\hline Amostra & $\mathrm{F} \exp (\mathrm{N})$ & $\log \mathrm{F} \exp$ & $\mathrm{Pf}$ & $1-\mathrm{Pf}$ & $1 /(1-\mathrm{Pf})=\mathrm{Q}$ & $\log \mathrm{Q}$ & $\log (\log \mathrm{Q}))$ \\
\hline 1 & 172,5300 & 2,2369 & 0,0909 & 0,9091 & 1,1000 & 0,0414 & $-1,3831$ \\
\hline 2 & 172,8900 & 2,2378 & 0,1818 & 0,8182 & 1,2222 & 0,0872 & $-1,0597$ \\
\hline 3 & 173,4200 & 2,2391 & 0,2727 & 0,7273 & 1,3750 & 0,1383 & $-0,8592$ \\
\hline 4 & 174,4400 & 2,2416 & 0,3636 & 0,6364 & 1,5714 & 0,1963 & $-0,7071$ \\
\hline 5 & 174,6700 & 2,2422 & 0,4545 & 0,5455 & 1,8333 & 0,2632 & $-0,5796$ \\
\hline 6 & 174,8900 & 2,2428 & 0,5455 & 0,4545 & 2,2000 & 0,3424 & $-0,4654$ \\
\hline 7 & 175,1600 & 2,2434 & 0,6364 & 0,3636 & 2,7500 & 0,4393 & $-0,3572$ \\
\hline 8 & 175,5100 & 2,2443 & 0,7273 & 0,2727 & 3,6667 & 0,5643 & $-0,2485$ \\
\hline 9 & 175,3800 & 2,2440 & 0,8182 & 0,1818 & 5,5000 & 0,7404 & $-0,1306$ \\
\hline 10 & 175,5600 & 2,2444 & 0,9091 & 0,0909 & 11,0000 & 1,0414 & 0,0176 \\
\hline
\end{tabular}

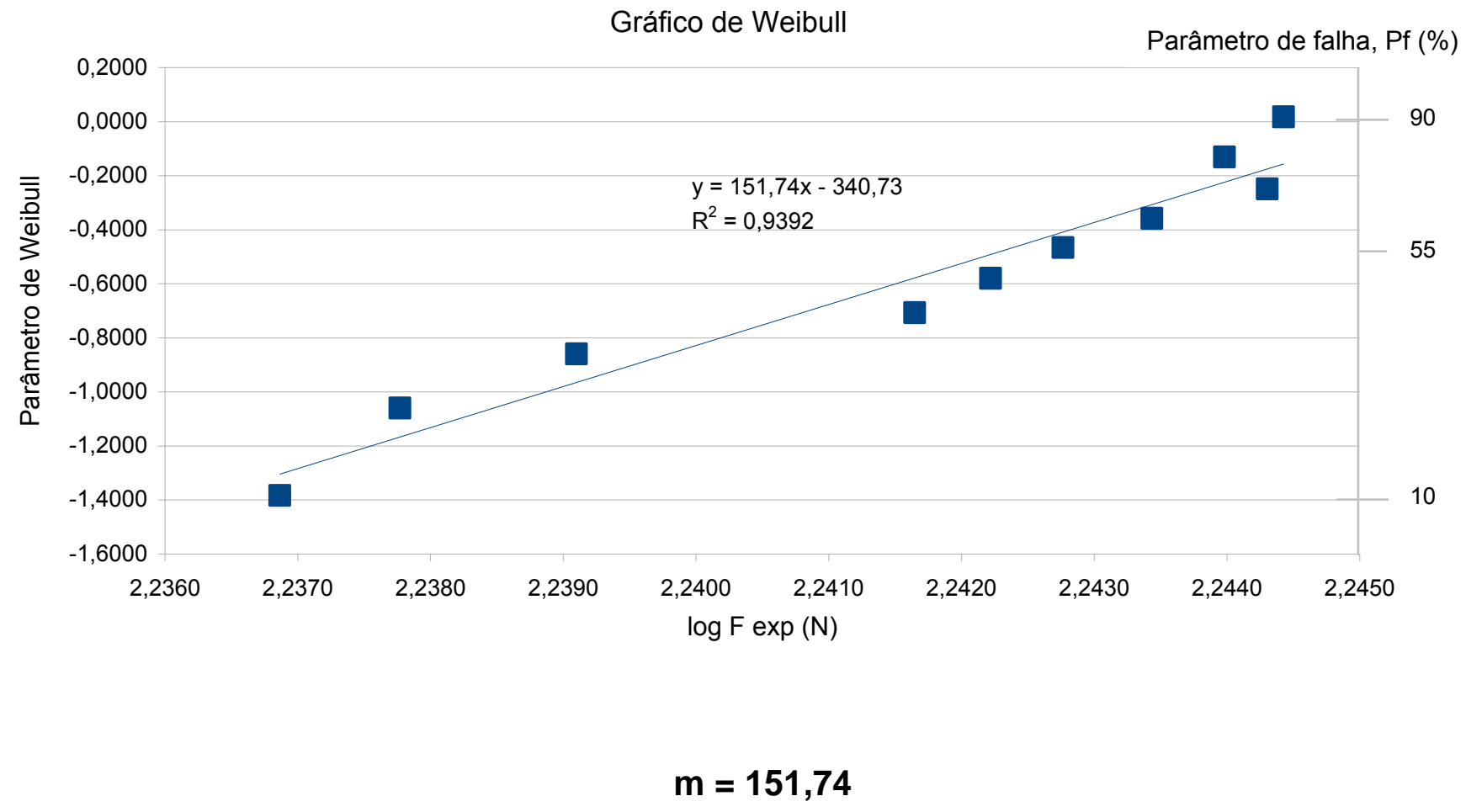




\section{A2 - Estatística de Weibull para a fibra de náilon do tipo singela da amostra “B”}

\begin{tabular}{|c|c|c|c|c|c|c|c|}
\hline Amostra & $\mathrm{F} \exp (\mathrm{N})$ & $\log \mathrm{F} \exp$ & $\mathrm{Pf}$ & $1-\mathrm{Pf}$ & $1 /(1-\mathrm{Pf})=\mathrm{Q}$ & $\log \mathrm{Q}$ & $\log (\log \mathrm{Q})$ \\
\hline 1 & 170,7500 & 2,2324 & 0,0909 & 0,9091 & 1,1000 & 0,0414 & $-1,3831$ \\
\hline 2 & 171,3700 & 2,2339 & 0,1818 & 0,8182 & 1,2222 & 0,0872 & $-1,0597$ \\
\hline 3 & 172,0000 & 2,2355 & 0,2727 & 0,7273 & 1,3750 & 0,1383 & $-0,8592$ \\
\hline 4 & 172,0000 & 2,2355 & 0,3636 & 0,6364 & 1,5714 & 0,1963 & $-0,7071$ \\
\hline 5 & 172,5300 & 2,2369 & 0,4545 & 0,5455 & 1,8333 & 0,2632 & $-0,5796$ \\
\hline 6 & 172,9300 & 2,2379 & 0,5455 & 0,4545 & 2,2000 & 0,3424 & $-0,4654$ \\
\hline 7 & 173,2000 & 2,2385 & 0,6364 & 0,3636 & 2,7500 & 0,4393 & $-0,3572$ \\
\hline 8 & 174,4000 & 2,2415 & 0,7273 & 0,2727 & 3,6667 & 0,5643 & $-0,2485$ \\
\hline 9 & 174,8900 & 2,2428 & 0,8182 & 0,1818 & 5,5000 & 0,7404 & $-0,1306$ \\
\hline 10 & 174,8900 & 2,2428 & 0,9091 & 0,0909 & 11,0000 & 1,0414 & 0,0176 \\
\hline
\end{tabular}

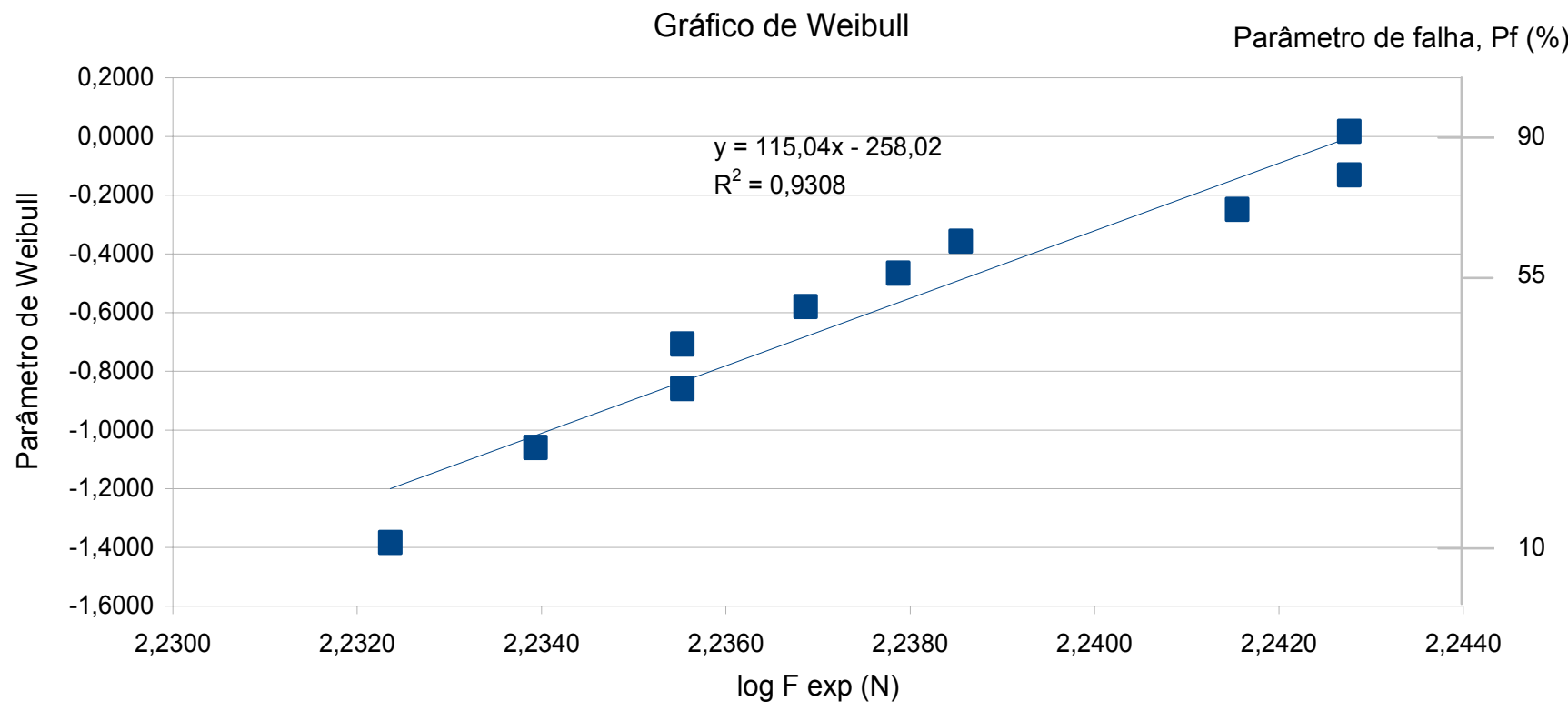

$\mathrm{m}=115$ 


\section{A3 - Estatística de Weibull para a fibra de poliéster do tipo singela da amostra "C"}

\begin{tabular}{|c|c|c|c|c|c|c|c|}
\hline Amostra & $\mathrm{F} \exp (\mathrm{N})$ & $\log \mathrm{F} \exp$ & $\mathrm{Pf}$ & $1-\mathrm{Pf}$ & $1 /(1-\mathrm{Pf})=\mathrm{Q}$ & $\log \mathrm{Q}$ & $\log (\log \mathrm{Q})$ \\
\hline 1 & 83,8200 & 1,9233 & 0,0909 & 0,9091 & 1,1000 & 0,0414 & $-1,3831$ \\
\hline 2 & 84,8000 & 1,9284 & 0,1818 & 0,8182 & 1,2222 & 0,0872 & $-1,0597$ \\
\hline 3 & 85,0600 & 1,9297 & 0,2727 & 0,7273 & 1,3750 & 0,1383 & $-0,8592$ \\
\hline 4 & 85,5100 & 1,9320 & 0,3636 & 0,6364 & 1,5714 & 0,1963 & $-0,7071$ \\
\hline 5 & 85,6900 & 1,9329 & 0,4545 & 0,5455 & 1,8333 & 0,2632 & $-0,5796$ \\
\hline 6 & 85,7800 & 1,9334 & 0,5455 & 0,4545 & 2,2000 & 0,3424 & $-0,4654$ \\
\hline 7 & 86,0400 & 1,9347 & 0,6364 & 0,3636 & 2,7500 & 0,4393 & $-0,3572$ \\
\hline 8 & 86,5300 & 1,9372 & 0,7273 & 0,2727 & 3,6667 & 0,5643 & $-0,2485$ \\
\hline 9 & 87,1100 & 1,9401 & 0,8182 & 0,1818 & 5,5000 & 0,7404 & $-0,1306$ \\
\hline 10 & 88,7100 & 1,9480 & 0,9091 & 0,0909 & 11,0000 & 1,0414 & 0,0176 \\
\hline
\end{tabular}

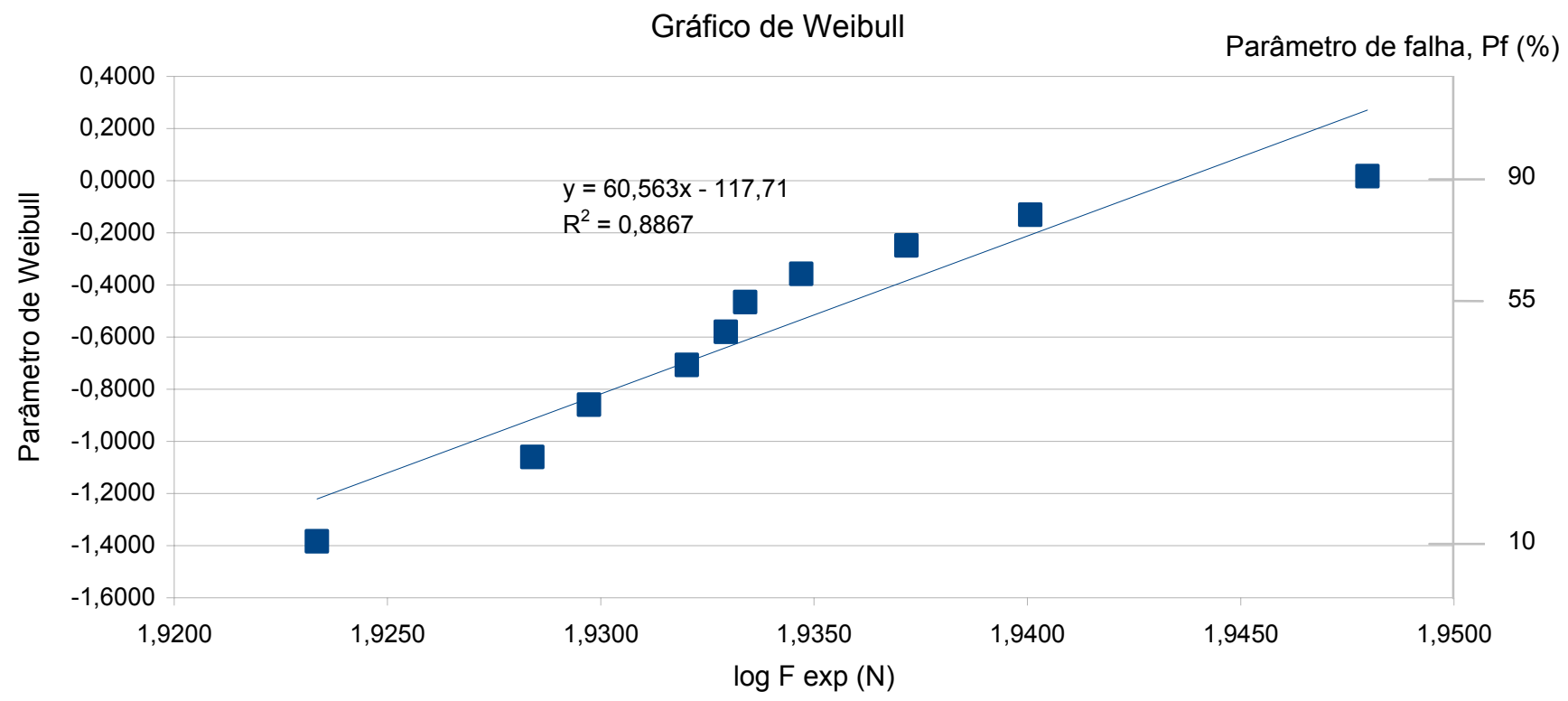

$m=60,56$ 
A4 - Estatística de Weibull para a fibra de poliéster do tipo singela da amostra “' $D$ ”

\begin{tabular}{|c|c|c|c|c|c|c|c|}
\hline Amostra & $\mathrm{F} \exp (\mathrm{N})$ & $\log \mathrm{F} \exp$ & $\mathrm{Pf}$ & $1-\mathrm{Pf}$ & $1 /(1-\mathrm{Pf})=\mathrm{Q}$ & $\log \mathrm{Q}$ & $\log (\log \mathrm{Q})$ \\
\hline 1 & 83,1500 & 1,9199 & 0,0909 & 0,9091 & 1,1000 & 0,0414 & $-1,3831$ \\
\hline 2 & 84,0400 & 1,9245 & 0,1818 & 0,8182 & 1,2222 & 0,0872 & $-1,0597$ \\
\hline 3 & 84,4400 & 1,9265 & 0,2727 & 0,7273 & 1,3750 & 0,1383 & $-0,8592$ \\
\hline 4 & 86,3100 & 1,9361 & 0,3636 & 0,6364 & 1,5714 & 0,1963 & $-0,7071$ \\
\hline 5 & 86,9300 & 1,9392 & 0,4545 & 0,5455 & 1,8333 & 0,2632 & $-0,5796$ \\
\hline 6 & 87,8200 & 1,9436 & 0,5455 & 0,4545 & 2,2000 & 0,3424 & $-0,4654$ \\
\hline 7 & 87,8700 & 1,9438 & 0,6364 & 0,3636 & 2,7500 & 0,4393 & $-0,3572$ \\
\hline 8 & 88,2700 & 1,9458 & 0,7273 & 0,2727 & 3,6667 & 0,5643 & $-0,2485$ \\
\hline 9 & 88,4000 & 1,9465 & 0,8182 & 0,1818 & 5,5000 & 0,7404 & $-0,1306$ \\
\hline 10 & 88,6200 & 1,9475 & 0,9091 & 0,0909 & 11,0000 & 1,0414 & 0,0176 \\
\hline
\end{tabular}

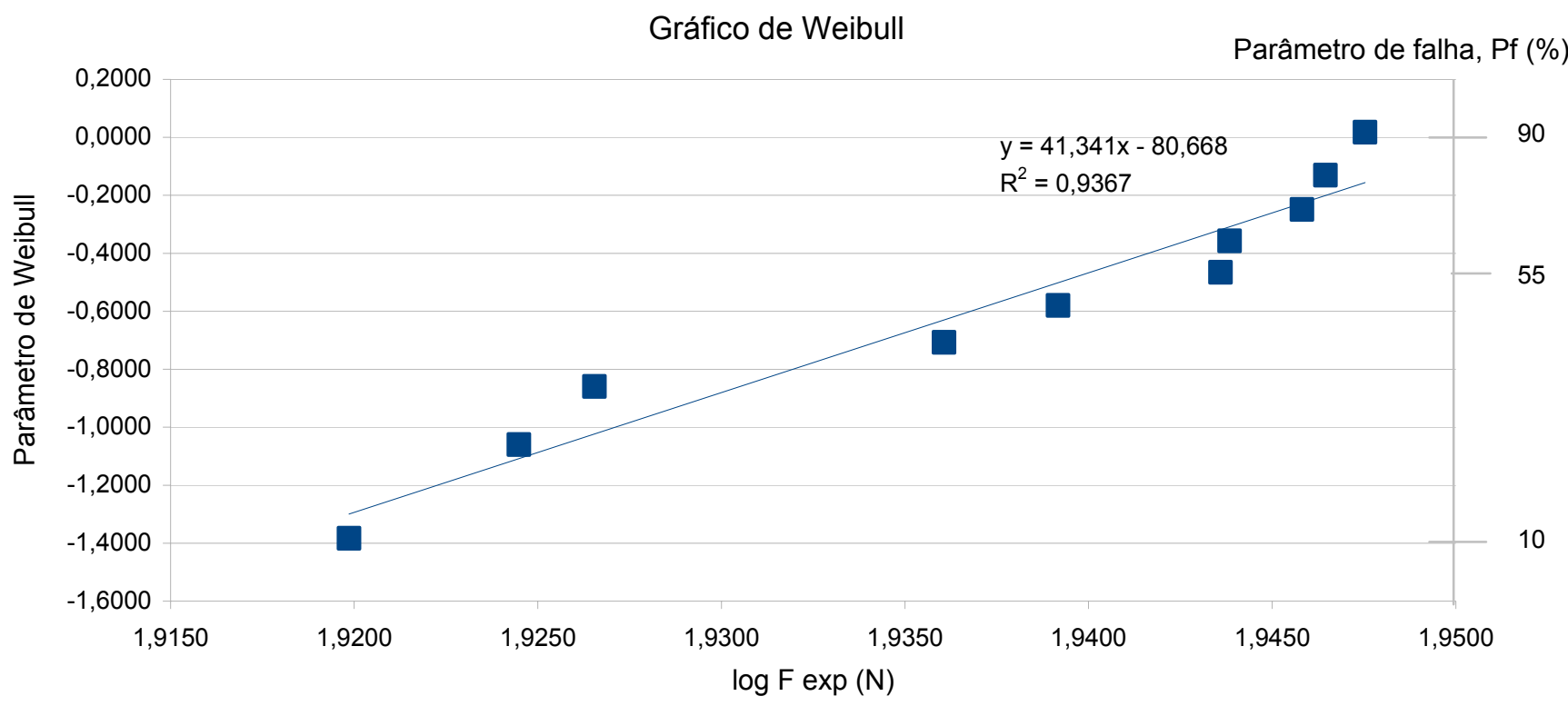

$m=41,34$ 


\section{REFERÊNCIAS BIBLIOGRÁFICAS}

ABBAS, M. Chemical and Thermal Resistance of Textile Reinforcing Materials: Mechanical Rubber Goods. Acordis Industrial Fibers, Netherlands, p. 1-28, Jul. 1999. Disponível em: www.acordis.com. Acesso em: 10 mar. 2006.

ANDERSON, T. L. Fracture Mechanics: Fundamentals and Applications, Fracture Mechanics in Nonmetals, CRC, 3. ed. p. 265-270, 2005.

ARROYO, M. Thermoplastic Polyesters. In: OLABISI, O. Handbook of thermoplastics. New York, NY: M. Dekker, 1997. cap. 18, p. 417-440.

ASKELAND, D. R.; PHULÉ P. P. The Science and Engineering of Materials. EUA: Brooks/ColeThomson, 4. ed. cap. 6, 2003.

ASSOCIAÇÃO BRASILEIRA DE PRODUTORES DE FIBRAS ARTIFICIAIS E SINTÉTICAS. $\boldsymbol{A}$ Indústria Brasileira de Fibras Artificiais e Sintéticas. São Paulo, SP, 1999.

BAKER, A. M. M.; MEAD, J. Thermoplastics, Plastics Engineering Department. In: HARPER, C. A. Modern Plastics Handbook. University Massachusetts, Lowel, McGraw-Hill, 2000. cap.1, p. 1.1-1.2.

BANERJEE, D.; LAO, J.; REN, Z. Design of nanostructured materials. In: SCHUTZ, M. J.; KELKAR, A. D.; SUNDARESAN, M. J. Nanoengineering of structural, functional and smart materials. New York, NY: CRC, 2005. cap. 2, p. 15-18.

BARAMBOIN, N. K. Mechanokhimiya Vysokomol, Soedin. Khimiya, Moscou. 1978. p. 7.

BARBOSA, M. C.; SILVEIRA, S. E.; CORREIA, A. R.; DVORSAK, P.; GOMES, G. L. Setor de fibras sintéticas e suprimento de intermediárias petroquímicas. [s.I :s.n.] 2004.

BELTRAN, J. F.; WILLIAMSON, E. B. Investigation of the Damage - Dependent Response of Mooring Ropes. In: Proceedings of the Fourteen International Offshore and Polar Engineering Conference. Honolulu, Hawai, USA, 2004.

BENDAK, A.; MARSAFI, S. M. E. Effects of Chemical Modifications on Polyester Fibers. Journal of Islamic Academy of Sciences, v. 4, n. 4, p. 275-284, 1991.

CANEVAROLO JÚNIOR, S. V. Ciência dos Polímeros: um texto básico para tecnólogos e engenheiros. São Carlos, SP: Artiber, 2002.

CARDOSO, S. G.; ANDRADE, A. H. P. Influence of Temperature in the Mechanical Properties of High Performance Pa 6.6 Synthetic Fiber after Dipping Process In: $11^{\text {th }}$ International Conference on Advanced Materials ICAM, Rio de Janeiro - RJ, sept. 2009a.

CARDOSO, S. G.; ANDRADE, A. H. P. Study of Fracture Mechanismics of High Performance Polyester Fibers In: $11^{\text {th }}$ International Conference on Advanced Materials ICAM, Rio de Janeiro RJ, sept. 2009b.

CARDOSO, S. G.; SILVA, E. P.; ANDRADE, A. H. P. A. Resistência Mecânica de Fibras Têxteis Utilizadas em Tecidos Técnicos de Alta Resistência. Revista Têxtil Brasil, São Paulo - SP, $n^{\circ} 679$ 5. ed. p. 52-55, may 2005. 
CHANDA, M.; ROY, S. K. Plastics technology handbook: plastics engineering series. 4. ed. United States: CRC, 2006. cap. 3, p. 1-66, cap. 5, p. 1-4.

CHAUVEL, A. ; LefEBVRE, G.; CASTEX, L. Petrochemical Processes: Características Técnicas e Econômicas. 2. ed., Paris: Technip, 1992. (Publicações do Instituto Francês de Petróleo)

CHOUDHURY, A. K. R. Textile preparation and dyeing. [s.I.]: Science. 2006. cap. 1, Chemistry of textile materials. p. 1-9, p. 27-39.

COLLIER, B.J.; TORTORA, P.G. Understing textile. 11. ed. Upper Saddler River, New Jersey: Prentice Hall, 2001.

DEANIN, R. D.; MEAD, J. L. Synthetic Resins an Plastics. In: RIEGEL, E. R.; KENT, A. J. Handbook of Industrial Chemistry. 3. ed. New York, NY: Academic, 2003. p. 662-663.

ELIAS H. G. An introduction to plastics. 2. ed. Germany: Wiley, 2003. p. 240-268.

EVSTATIEV, M. Polyamides. In: OLABISI, O. Handbook of thermoplastics. New York, NY: M. Dekker, 1997. cap. 27, p. 641-642.

FEDERAL TRADE COMMISION. In: Midwest Paralegal Studies, Disponível em: www.cyberparalegal.com/fdc act.htm. 2003.

FOSTER, G. P. Advantages of Fiber Rope Over Wire Rope. Journal of Industrial Textiles. v. 32, n. 1, p. 67-75, 2002.

FUNDAÇÃO GETÚLIO VARGAS. Análise da Eficiência Econômica e da competitividade da Cadeia Têxtil Brasileira. Rio de Janeiro, RJ, 1999.

FUNG, W.; HARDCASTLE, M. Textiles in Automotive Engineering. The Textile Institute, Woodhead, p. 107-111, 2001.

GHILLÉN, J. G. Fibras de Poliéster. Universidade Politécnica da Catalunha. Terrasa, Espanha. 1991. p. 13.

GHILLÉN, J. G. Nomes Genéricos de Fibras Químicas Normativas e Legislação. Revista Química Têxtil, Ano XXVI, n. 70, p. 29, mar 2003.

GOODYEAR CONVEYOR BELT PRODUCTS version 1.0: Handbook of Conveyor \& Elevator Belting. USA, 2000. 1 CD ROM.

GOODYEAR ENGINEERED PRODUCTS: Finite element analysis technology conveyor belting. Akron, Ohio. 2007.

GODINHO, A. C.; Seminário Dipagem: Processo, Equipamento e Aspectos de Qualidade. Techtextil South America, São Paulo, nov. 2003.

GOSWAMI, B. C.; ANANDJIWALA, R. D.; HALL, D. M. Textile sizing. New York, NY: M. Dekker, 2004. p. 9-35, 219-220. 
GROREISHI, S. R.; CARTRAUD, P.; DAVIES, P.; MESSAGER, T. Analytical modeling of synthetic fiber ropes subjected to axial loads. International journal of solids and structures. v. 44, part 1: A new continuum model for multilayered fibrous structures. Nantes, France: Elsevier, 1 may 2007.

HALL, M. E. Coating of Technical Textiles. In: HORROCKS, A. R.; ANAND, S. C. Handbook of technical textiles. Boca Raton, FL: CRC, 2000. cap. 8, p. 173-185.

HEARLE, J. W. S. High performance fibers. Cambridge, UK: WP, 2001. cap. 1, p. 1-15.

HEARLE, J. W. S.; LOMAS, B.; COOKE, W. D. Atlas of fiber fracture and damage to textiles. 2. ed. Boca Raton, FL: CRC, 1998. p. 42-43, 50-51.

HEARLE, J. W. S. UIImann's fibers: encyclopedia of industrial chemistry: fiber classes, production and characterization. v. 1, Weinheim, Germany: Wiley, 2008. p. 152-153, 83-84, 39-41.

HONGU, T.; PHILIPS, G. O.; TAKAGAMI, M. New millennium fibers. Cambridge, UK: WP, 2005. p. $1-12,65-68$.

JAMSHIDI, M.; TAROMI, F. A.; MOHAMMADI, N. The effect of temperature on interfacial interaction of cord-rfl rubber system. Iranian Journal Polymer. 15 aug. 2004. p. 229-234.

KERR, M.; CHAWLA, N.; CHAWLA, K. K. The Cyclic Fatigue of High-Performance Fibers. Journal of Metals, p. 67-70, Feb. 2005.

LEWANDOWSKI, S.; LINEK, M.; SLUSARCZYK, C.; KASZTELNIK, A. Assessment of the Supermolecular Polyester Fibers and Those with Reduced Susceptibility to Pilling, as Processed by the Uncontrolled Breaking Method, Indian Academy of Sciences, Fibers \& Textiles in Eastern Europe, v. 11, n. 2, Poland, Jun. 2003.

LEWIN, M. Handbook of fiber chemistry. 3. ed. New York, NY: CRC, 2006. cap. 2, p. 59-83.

MALLICK, B.; BEHERA, R. C.; PATEL, T. Analysis of Microstress in Irradiated Polyester Fiber by Xray Diffraction Technique. Indian Academy of Sciences, v. 28, n. 6, p. 593-598, 2005.

MARCELLAN, A.; BULSELL, A. R.; PIQUES, R.; COLOMBAN, P. Microstructural mechanismics and mechanical properties during loading and fracture of PA 66 high performance fibers. Paris, France, 2003,. p. 1-10.

MCKENNA, H. A.; HEARLE, J. W. S.; O'HEAR, N. Handbook of fiber rope technology. Cambridge, UK: CRC, 2004. p. 75-78, 101-104, 141-144.

MECHEELS, S. INTERNATIONAL CONGRESS OF NANOTECHNOLOGY ITM EXPO: Benefits of the Nanotechnology Revolution for Textiles. July 3-7, Sao Paulo, 2005.

MIRAFTAB, M. Technical Fibres. In: HORROCKS, A. R.; ANAND, S. C. Handbook of technical textiles. Boca Raton, FL: CRC, 2000. cap. 2, p. 24-39.

MORTENSEN, A. Concise encyclopedia of composite materials. 2. ed. Amsterdam, N.: Elsevier, 2007. p. 382-383. 
MURPHY, G. Conveyor Belting. In: WAKE, C. W.; WOOTTON, D. B. Textile Reinforcement of Elastomers. New Jersey, USA: Applied Science Publishers, 1982. cap. 6, p. 133-163.

PACKHAM, D. E. Handbook of adhesion. 2. ed. Bath, UK: Wiley, 2005. p. 16-18, 28-32, 32-33.

PEREIRA, M. A. Associação brasileira das indústrias de não tecidos e tecidos técnicos. Manual de têxteis técnicos. ABINT. 2. ed. [s.l.] 2005.

PETERS, E. N. Plastics: Thermoplastics, Thermosets, and Elastomers. In: KUTZ, M. Handbook of materials selection. New York, NY: Wiley \& Sons, 2002. cap. 11, p. 336-354.

RAHEEL, M. Modern textile characterization methods. New York,NY: M. Dekker,1999. p. 9-12, 145-150.

RAMIREZ, J. M. H.; COLOMBAN, P.; BUNSELL, A., Micro-Raman study of the fatigue fracture and tensile behavior of polyamide ( $\mathrm{Pa} 66$ ) fibers. Journal of Raman Spectroscopy, v. 35, p. 1063-1072, 2004.

RAN, S.; CRUZ, S.; ZONG, X.; FANG, D.; CHU, B.; HSIAO, B. S. Structure Development during the Heat-Draw Process of Nylon 66 Fiber by Synchrotron X-ray Diffraction. International Centre for Diffraction, Advances in X-ray Analysis, New York, N. Y., 2000. vol. 43, p. 313-317.

RIANDE, E.; DÍAZ-GALleJA, R.; PROLONGO, M. G.; MASEGOSA, R. M.; SALOM, C. Polymer viscoelasticity: stress and strain in practice. New York, NY: M. Dekker, 1999. p. 1-7, 582-587.

RICHARDS, A. F. Náilon fibres. In: MCLNTYRE, J. E. Synthetic fibers nylon, polyester, acrylic, polyolefin. Boca Raton, FL: CRC, 2004. cap. 2, p. 20-23.

RIEDEL, U.; NICKEL, J.; HERRMANN, A. S. High Performance Applications of Plant Fibers in Aerospace and Related Industries. German Aerospace Center, Germany, p. 1-10, 1998.

ROYLANCE, D. Mechanics of Materials: Introduction to Fracture Mechanics. p. 1-17. Department of Materials Science and Engineering, Institute of Technology Cambridge, June 2001.

SANTOS, L. Nanotecnologia e nanoestruturas. 2004. Monografia - Instituto de Química de São Carlos, São Paulo.

SAWYER, L. C.; GRUBB, D. T. Polymer microscopy. 2. ed. London, UK: Springer, 1996. p. 174183, 315-318.

SCHINDLER, W.; FINNIMORE, F. Chemical analysis of damage to textiles. In: FAN, Q. Chemical testing of textiles. Manchester, UK: CRC, 2005. p. 145-146.

SEN, A. K. COATED TEXTILES: Principles and Applications. 2. ed. New York, N Y: CRC, 2007. Cap. 2, Textile Substrate for Coated Fabrics. p. 47-61.

SHUKLA, A. Practical fracture mechanics in design. 2. ed. New York, NY: M. Dekker, 2005. Cap. 5, p. 149-153.

SINDICATO DAS INDÚSTRIAS DE TECELAGEM DE AMERICANA. Tecelagens de Tecidos Planos Artificiais e Sintéticos em Americana e Região. Americana, SP, 2001. 
SMITH, W. C. High-Performance Fibers Protect Improve Lives, v. 148, n. 10 p. 53-64, oct. 1998. ABI/INFORM Global

TOKAMAKI, Nanotecnologia, $\boldsymbol{A}$ habilidade de manipular a matéria na escala atômica. Disponível em: www.tokamaki.hpg.ig.com.br/nano.htm. Acesso em: 15 ago. 2003.

VASILIU-OPREA C.; DAN. F. Macromolecular mechanochemistry: polymer mechanochemistry. v. 1, part. 1. Cambridge, UK: CISP, 2003. p. 33-35, 170-173.

VLACK, L. H. van. Princípios de Ciência e Tecnologia dos Materiais. São Paulo, S P: Campus, 2002.

WASIAK, I. F.; SNYCERSKI, M.; STEM, P. Z.; SUSZEK, H. Measuring Method of Multidirectional Force Distribution in Woven Fabric. Fibers \& Textiles in Europe, v. 12, n. 2. p. 48-51, 2004.

WOOTTON, D. B. Preparation and Design of Textile Structures. In: WAKE, C. W.; WOOTTON, D. B. Textile Reinforcement of Elastomers. New Jersey, USA: Applied Science Publishers, 1982. cap. 3, p. 41-53. 